\title{
Types and Amounts of Complementary Foods and Beverages Consumed and Growth, Size, and Body Composition: A Systematic review
}

The Pregnancy and Birth to 24 Months Project

Published date: April 15 2019

Nutrition Evidence Systematic Review Center for Nutrition Policy and Promotion

Food and Nutrition Service

U.S. Department of Agriculture

3101 Park Center Drive

Alexandria, Virginia 
This systematic review was conducted by the Nutrition Evidence Systematic Review (NESR) team at the Center for Nutrition Policy and Promotion, Food and Nutrition Service, USDA. This systematic review was completed for the Pregnancy and Birth to 24 Months Project (P/B-24). All systematic reviews from the P/B-24 Project are available on the NESR website: https://nesr.usda.gov.

Conclusion statements drawn as part of this systematic review describes the state of science related to the specific question examined. Conclusion statements do not draw implications, nor should they be interpreted to be dietary guidance.

The contents of this document may be used and reprinted without permission. Endorsement by NESR, the Center for Nutrition Policy and Promotion, the Food and Nutrition Service, or the U.S. Department of Agriculture of derivative products developed from this work may not be stated or implied.

In accordance with Federal civil rights law and U.S. Department of Agriculture (USDA) civil rights regulations and policies, the USDA, its Agencies, offices, and employees, and institutions participating in or administering USDA programs are prohibited from discriminating based on race, color, national origin, religion, sex, gender identity (including gender expression), sexual orientation, disability, age, marital status, family/parental status, income derived from a public assistance program, political beliefs, or reprisal or retaliation for prior civil rights activity, in any program or activity conducted or funded by USDA (not all bases apply to all programs).

Remedies and complaint filing deadlines vary by program or incident.

Persons with disabilities who require alternative means of communication for program information (e.g., Braille, large print, audiotape, American Sign Language, etc.) should contact the responsible Agency or USDA's TARGET Center at (202) 720-2600 (voice and TTY) or contact USDA through the Federal Relay Service at (800) 877-8339. Additionally, program information may be made available in languages other than English.

To file a program discrimination complaint, complete the USDA Program Discrimination Complaint Form, AD3027, found online at How to File a Program Discrimination Complaint and at any USDA office or write a letter addressed to USDA and provide in the letter all of the information requested in the form. To request a copy of the complaint form, call (866) 632-9992. Submit your completed form or letter to USDA by: (1) mail: U.S.

Department of Agriculture, Office of the Assistant Secretary for Civil Rights, 1400 Independence Avenue, SW, Washington, D.C. 20250-9410; (2) fax: (202) 690-7442; or (3) email: program.intake@usda.gov.

USDA is an equal opportunity provider, employer, and lender.

Suggested citation for this systematic review: Nutrition Evidence Systematic Review Team and Complementary Feeding Technical Expert Collaborative. Types and Amounts of Complementary Foods and Beverages Consumed and Growth, Size, and Body Composition: A Systematic Review. Pregnancy and Birth to 24 Months Project. Alexandria, VA: U.S. Department of Agriculture, Food and Nutrition Service, Center for Nutrition Policy and Promotion, February 2019. Available at: https://nesr.usda.gov/project-specific-overviewpb-24-0

This systematic review has also been published in the American Journal of Clinical Nutrition: English LK, Obbagy JO, Wong YP, Butte NF, Dewey KG, Fox MK, Greer FR, Krebs NK, Scanlon KS, Stoody EE, et al. Types and amounts of complementary foods and beverages consumed and growth, size, and body composition: a systematic review. Am J Clin Nutr. 2019;109(7):956S-77S. doi: 10.1093/ajcn/nqy281.

\section{Related citations:}

- P/B-24 Project overview: Stoody EE, Spahn JM, Casavale KO. The Pregnancy and Birth to 24 Months Project: a series of systematic reviews on diet and health. Am J Clin Nutr. 2019;109(7):685S697S. doi: 10.1093/ajcn/nqy372

- P/B-24 systematic review methodology: Obbagy JE, Spahn JS, Psota TL, Spill MK, Dreibelbis C, Gungor DE, Nadaud PN, Raghavan R, Callahan EH, English LK, Kingshipp BJ, Lapergola CC, Shapiro MJ, Stoody EE. Systematic review methodology used in the Pregnancy and Birth to 24 Months Project. Am J Clin Nutr 2019;109(7):698S-704S. doi: 10.1093/ajcn/nqy226

- Related systematic reviews from the P/B-24 Project: English L, Obbagy JE, Wong YP, Butte NF, 
Dewey KG, Fox MK, Greer FR, Krebs NF, Scanlon KS, Stoody EE. Timing of introduction of complementary foods and beverages and growth, size, and body composition: a systematic review. Am J Clin Nutr. 2019: 109(7): 935S-55S doi: 10.1093/ajcn/nqy267 


\section{ACKNOWLEDGEMENTS}

\section{Technical Expert Collaborative (TEC) members:}

- Nancy F. Butte, PhD, RD, USDA/ARS Children's Nutrition Research Center, Baylor College of Medicine, Department of Pediatrics, Emeritus

- Kathryn G. Dewey, PhD, University of California, Davis, Department of Nutrition

- David M. Fleischer, MD, Children's Hospital Colorado, University of Colorado School of Medicine, Department of Pediatrics, Section of Allergy and Immunology

- Mary Kay Fox, Med, Mathematic Policy Research

- Frank R. Greer, MD, University of Wisconsin School of Medicine and Public Health, Department of Pediatrics, Emeritus

- Nancy F. Krebs, MD, MS, University of Colorado School of Medicine, Department of Pediatrics

- Kelley S. Scanlon, PhD, RD, USDA Food and Nutrition Service; formerly of the Centers for Disease Control and Prevention, Division of Nutrition, Physical Activity, and Obesity

\section{Nutrition Evidence Systematic Review (NESR) team:}

- Laural K. Englishi, PhD, Panum Group, Lead Analyst (11/2016-project completion)

- Julie E. Obbagy, PhD, RD, USDA, Analyst (05/2016-project completion)

- Yat Ping Wong, MLS, MPH, USDA, Librarian

- Tricia Psota, PhD, USDA, Analyst (07/2015-06/2016)

- Perrine Naudadi, PhD, Panum Group, Analyst (07/2015-05/2016)

- Kirsten Johnsi, MS, Panum Group, Analyst (07/2015-05/2016)

- Nancy Terry, MLS, NIH, Librarian

\section{Project Leads:}

- Eve Essery Stoody, PhD, USDA

\section{Federal Expert Group (FEG)-Technical Expert Collaborative (TEC) Liaisons:}

- Kelley Scanlon, PhD RD, USDA Food and Nutrition Service; formerly of the Centers for Disease Control and Prevention, Division of Nutrition, Physical Activity, and Obesity

All TEC and NESR team members, Project leads, and FEG-TEC liaisons participated in establishing the research questions, analytic framework, and study inclusion and exclusion criteria. LKE, JEO, TLP, YWP, PN, KJ, and NT developed and conducted the literature search, screened search results, and identified studies for inclusion. LKE and JEO extracted data and assessed risk of bias for included studies. NFC, KGD, DMF, MKF, FRG, NFK, and KSS reviewed and provided substantive feedback on all systematic review materials, including the synthesis of the body of evidence, conclusion

i Under contract with the Food and Nutrition Service, United States Department of Agriculture. 
statement, and grade of the strength of the evidence. LKE prepared this report and EES provided oversight. All authors critically reviewed and approved the final report. The authors declare no conflicts of interest.

FUNDING SOURCE: United States Department of Agriculture, Food and Nutrition Service, Center for Nutrition Policy and Promotion, Alexandria, VA 


\section{TABLE OF CONTENTS}

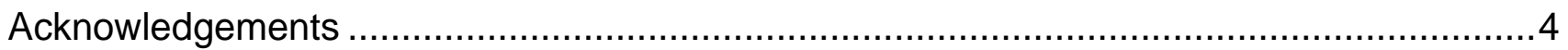

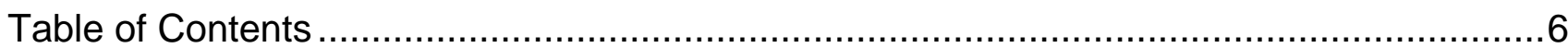

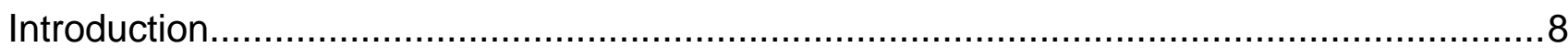

What is the relationship between the types and amounts of complementary foods and beverages consumed and growth, size, and body composition? .................................10

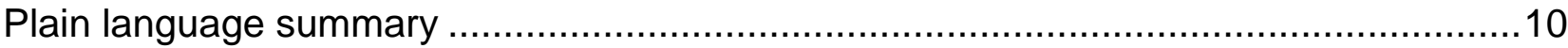

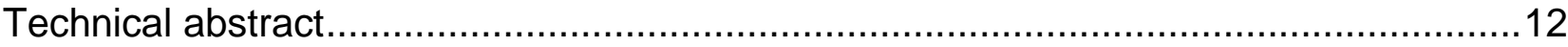

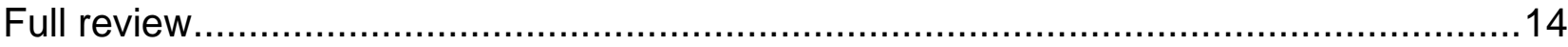

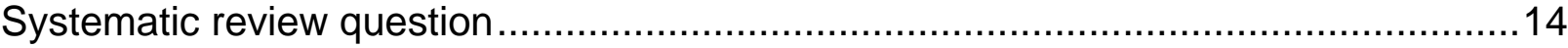

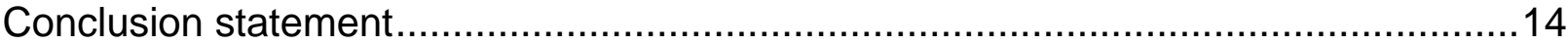

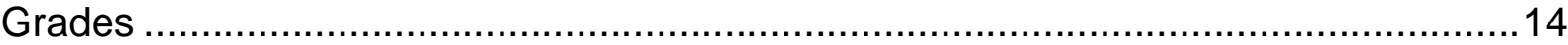

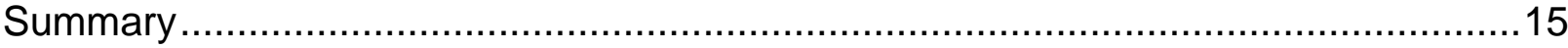

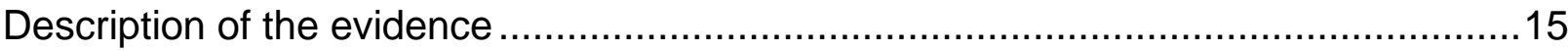

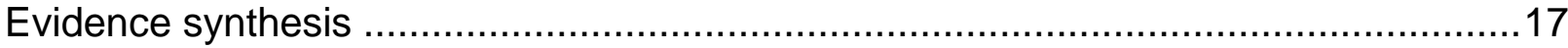

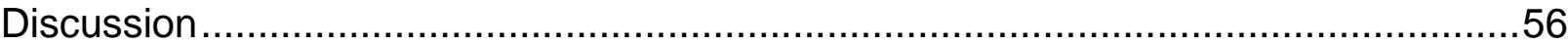

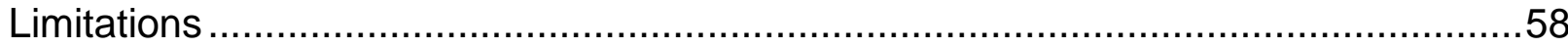

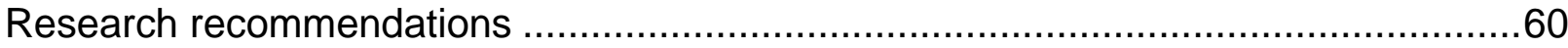

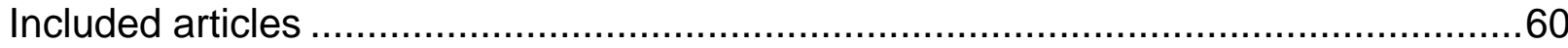

Other references

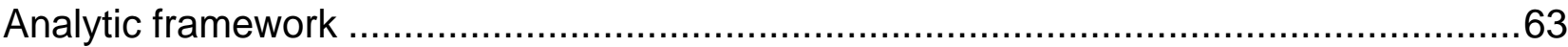

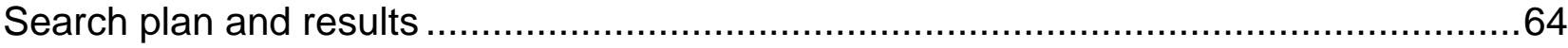

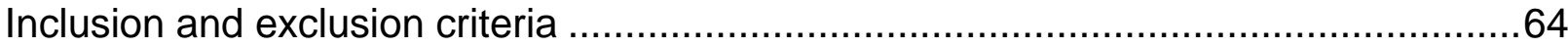

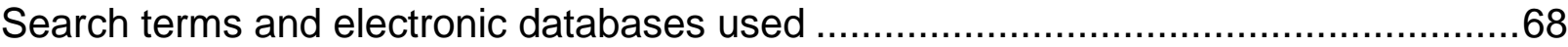

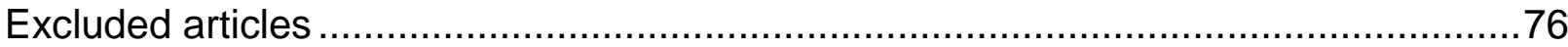

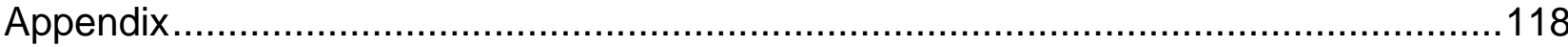

Table 1. Studies that examined meat, with or without cereal, and growth, size, and body

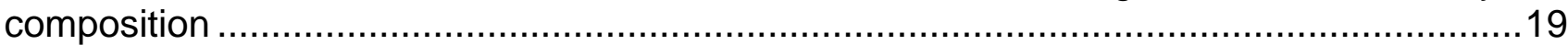

Table 2. Studies that examined cereal, and growth, size, and body composition................25

Table 3. Studies that examined CFB with different fats/fatty acid composition and growth,

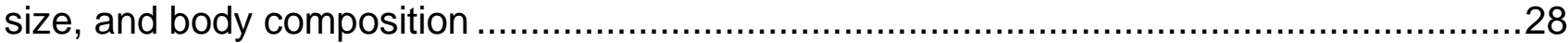

Table 4. Studies that examined SSB, juice drinks and/or 100\% juice and growth, size, and

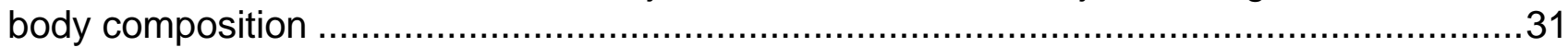

Table 5. Studies that examined other CFB and growth, size, and body composition ...........38

Table 6. Studies that examined dietary patterns during the complementary feeding period

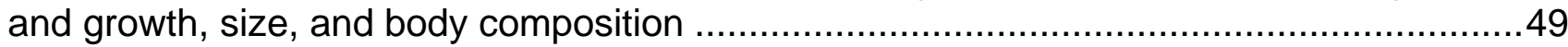




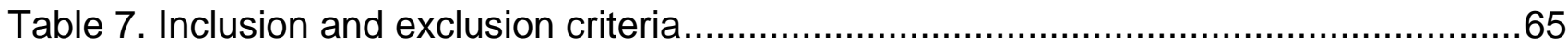

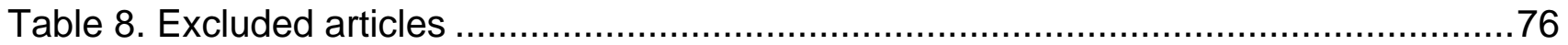

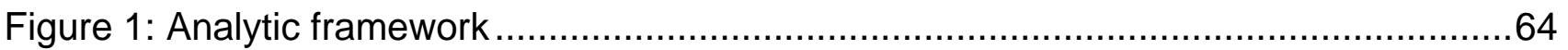

Figure 2: Flow chart of literature search and screening results ...............................75 


\section{INTRODUCTION}

This document describes a systematic review conducted to answer the following question: What is the relationship between types and amounts of complementary foods and beverages consumed and growth, size, and body composition?. This systematic review was conducted as part of the Pregnancy and Birth to 24 Months Project (P/B-24 Project) by USDA's Nutrition Evidence Systematic Review (NESR).

The purpose of the P/B-24 Project was to conduct a series of systematic reviews on diet and health for women who are pregnant and for infants and toddlers from birth to 24 months of age. This project was a joint initiative led by USDA and HHS, and USDA's NESR carried out all of the systematic reviews. A Federal Expert Group (FEG), a broadly representative group of Federal researchers and program leaders, also provided input throughout the P/B-24 Project. More information about the P/B-24 Project has been published ${ }^{2}$ and is available on the NESR website:

https://nesr.usda.gov/project-specific-overview-pb-24-0

NESR, formerly the Nutrition Evidence Library (NEL), specializes in conducting foodand nutrition-related systematic reviews using a rigorous, protocol-driven methodology. To conduct each P/B-24 systematic review, NESR's staff worked with a Technical Expert Collaborative (TEC), which is a group of 7-8 leading subject matter experts.

NESR's systematic review methodology involves developing and prioritizing systematic review questions, searching for and selecting studies, extracting and assessing the risk of bias of data from each included study, synthesizing the evidence, developing a conclusion statement, grading the evidence underlying the conclusion statement, and recommending future research. A detailed description of the methodology used in conducting systematic reviews for the P/B-24 Project has been published ${ }^{3}$ and is available on the NESR website: https://nesr.usda.gov/pb-24-project-methodology-0. In addition, starting on page 62, this document includes details about the methodology as it was applied to the systematic review described herein. An analytic framework that illustrates the overall scope of the question, including the population, the interventions and/or exposures, comparators, and outcomes of interest, is found on page 62 . In addition, the literature search plan, that was used to identify studies included in this systematic review is found on page 63.

\footnotetext{
2 Stoody EE, Spahn JM, Cassavale KO. The Pregnancy and Birth to 24 Months Project: a series of systematic reviews on diet and health. Am J Clin Nutr. 2019;109(7):685S-697S.

doi:10.1093/ajen/nqy372

${ }^{3}$ Obbagy JE, Spahn JS, Psota TL, Spill MK, Dreibelbis C, Gungor DE, Nadaud PN, Raghavan R, Callahan EH, English LK, Kingshipp BJ, Lapergola CC, Shapiro MJ, Stoody EE. Systematic review methodology used in the Pregnancy and Birth to 24 Months Project. Am J Clin Nutr.

2019;109(7):698S-704S. doi: 10.1093/ajcn/nqy226
} 


\section{List of abbreviations}

\begin{tabular}{ll}
\hline Abbreviation & Full name \\
\hline BF & Breast fed \\
\hline BMIZ & Body mass index z-score \\
\hline CF & Complementary feeding \\
\hline CFB & Complementary food and beverage \\
\hline DXA & Dual-energy X-ray absorptiometry \\
\hline EBF & Exclusively breast-fed \\
\hline EFF & Exclusively formula fed \\
\hline FEG & Federal expert group \\
\hline FF & Formula fed \\
\hline FFQ & Food frequency questionnaire \\
\hline FM & Fat mass \\
\hline HAZ & Height-for-age z-score \\
\hline HC & Head circumference \\
\hline HHS & Department of Health and Human Services \\
\hline LAZ & Length-for-age z-score \\
\hline NEL & Nutrition Evidence Library \\
\hline NESR & Nutrition Evidence Systematic Review \\
\hline NIH & National Institutes of Health \\
\hline P/B-24 & Pregnancy and Birth to 24 Months Project \\
\hline RCT & Randomized controlled trial \\
\hline SSB & Sugar-sweetened beverage \\
\hline TEC & Technical Expert Collaborative \\
\hline USDA & United States Department of Agriculture \\
\hline WAZ & Weight-for-age $z$ score \\
\hline WC & Waist circumference \\
\hline WLZ & Weight-for-length z score \\
\hline & \\
\hline
\end{tabular}




\section{WHAT IS THE RELATIONSHIP BETWEEN THE TYPES AND AMOUNTS OF COMPLEMENTARY FOODS AND BEVERAGES CONSUMED AND GROWTH, SIZE, AND BODY COMPOSITION?}

\section{PLAIN LANGUAGE SUMMARY}

\section{What is the question?}

- What is the relationship between the types and amounts of complementary foods and beverages consumed and growth, size, and body composition?

\section{What is the answer to the question?}

- Moderate evidence indicates that higher versus lower meat intake or meat versus iron-fortified cereal intake over a short duration $(-3 \mathrm{mo})$ during the complementary feeding period does not favorably or unfavorably influence growth, size, and/or body composition. There is insufficient evidence to determine a relationship between meat intake and prevalence/incidence of overweight or obesity.

- Limited evidence suggests that type or amount of cereal given does not favorably or unfavorably influence growth, size, body composition, and/or prevalence/incidence of overweight or obesity.

- Moderate evidence suggests that consumption of complementary foods with different fats and/or fatty acid composition does not favorably or unfavorably influence growth, size, or body composition. There is not enough evidence to determine a relationship between consumption of complementary foods with different fats and/or fatty acid composition and/or prevalence/incidence of overweight or obesity.

- Limited evidence suggests that sugar sweetened beverage consumption during the complementary feeding period is associated with increased risk of obesity in childhood, but is not associated with other measures of growth, size, and body composition.

- Limited evidence showed a positive association between juice intake and infant weight-for-length and child BMI z-scores.

- No conclusion could be made about the relationship between other complementary foods (vegetables, fruit, dairy products and/or cow's milk, cereal-based products, milk-cereal drink, and/or categories such as "readymade foods") and growth, size, body composition, and/or prevalence/incidence of overweight or obesity.

- No conclusion could be made about the relationship between distinct dietary patterns during the complementary feeding period and growth, size, body composition, and/or prevalence/incidence of malnutrition, overweight or obesity. 


\section{Why was this question asked?}

- This important public question was identified as part of the U.S. Department of Agriculture and Department of Health and Human Services Pregnancy and Birth to 24 Months Project

\section{How was this question answered?}

- A team of staff from the Nutrition Evidence Systematic Review conducted a systematic review in collaboration with a group of experts called a Technical Expert Collaborative.

\section{What is the population of interest?}

- Generally healthy infants and toddlers who were fed complementary foods and beverages from ages 0-24 months and had growth, size, and/or body composition outcomes measured across the lifespan

\section{What evidence was found?}

- Forty-nine articles were included that addressed type and/or amount of complementary foods and beverages consumed, including the introduction of specific complementary foods and beverages and dietary patterns during the complementary feeding period.

- The study designs included 18 randomized controlled trials, 1 nonrandomized controlled trial, and 30 prospective cohort studies

- The studies varied in terms of the types and/or amounts of CFB examined, which included dietary patterns consumed during the complementary feeding period, meat, cereal, foods with different fatty acid composition, SSB, juice or $100 \%$ juice, and other CFB

- The gaps and limitations in the evidence may include the following:

o Randomized controlled trials and studies that examine a wider range of specific types and amounts complementary foods and beverages,

o Research that accounts for the rationale for type/amount of complementary foods and beverages given (e.g., reverse causality), and adjusts for potential confounders (e.g., human milk and/or formula-feeding and baseline growth status).

\section{How up-to-date is this review?}

- This review includes literature from 01/1980 to 07/2016 


\section{TECHNICAL ABSTRACT}

\section{Background}

- The goal of this systematic review was to examine the following question: What is the relationship between types and amounts of complementary foods and beverages (CFB) consumed and growth, size, and body composition?

- Systematic reviews were conducted as part of the U.S. Department of Agriculture and Department of Health and Human Services Pregnancy and Birth to 24 Months Project.

- Complementary feeding is the process that starts when human milk or infant formula is complemented by other foods and beverages, beginning during infancy and typically continuing to 24 months of age. CFB were defined as foods and/or beverages other than human milk or infant formula (liquids, semisolids, and solids) provided to an infant or young child to provide nutrients and energy.

\section{Conclusion Statement}

- Moderate evidence indicates that higher versus lower meat intake or meat versus iron-fortified cereal intake over a short duration ( $-3 \mathrm{mo})$ during the complementary feeding period does not favorably or unfavorably influence growth, size, and/or body composition. There is insufficient evidence to determine a relationship between meat intake and prevalence/incidence of overweight or obesity.

- Limited evidence suggests that type or amount of cereal given does not favorably or unfavorably influence growth, size, body composition, and/or prevalence/incidence of overweight or obesity.

- Moderate evidence suggests that consumption of complementary foods with different fats and/or fatty acid composition does not favorably or unfavorably influence growth, size, or body composition. There is not enough evidence to determine a relationship between consumption of complementary foods with different fats and/or fatty acid composition and/or prevalence/incidence of overweight or obesity.

- Limited evidence suggests that sugar sweetened beverage consumption during the complementary feeding period is associated with increased risk of obesity in childhood, but is not associated with other measures of growth, size, and body composition.

- Limited evidence showed a positive association between juice intake and infant weight-for-length and child BMI z-scores.

- No conclusion could be made about the relationship between other complementary foods (vegetables, fruit, dairy products and/or cow's milk, cereal-based products, milk-cereal drink, and/or categories such as "readymade foods") and growth, size, body composition, and/or prevalence/incidence of overweight or obesity.

- No conclusion could be made about the relationship between distinct dietary patterns during the complementary feeding period and growth, size, body 
composition, and/or prevalence/incidence of malnutrition, overweight or obesity.

- Grades: Moderate - Meat; Different Fats and/or Fatty Acid Composition; Limited - Juice; Sugar-Sweetened Beverages; Grade Not Assignable Cereal; Other CFB; Dietary Patterns

\section{Methods}

- This systematic review was conducted by a team of staff from the Nutrition Evidence Systematic Review in collaboration with a Technical Expert Collaborative.

- Literature search was conducted using 4 databases (PubMed, Cochrane, Embase, and CINAHL) to identify articles that evaluated the intervention or exposure of types and amounts of CFB consumed and the outcomes of growth, size, and/or body composition. A manual search was conducted to identify articles that may not have been included in the electronic databases searched. Articles were screened by two analysts independently for inclusion based on pre-determined criteria.

- Data extraction and risk of bias assessment were conducted for each included study, and both were checked for accuracy. The body of evidence was qualitatively synthesized to inform development of a conclusion statement(s), and the strength of evidence was graded using pre-established criteria evaluating the body of evidence on risk of bias, adequacy, consistency, impact, and generalizability.

\section{Summary of the Evidence}

- This review includes 49 articles from 18 randomized controlled trials, 1 nonrandomized controlled trial, and 30 prospective cohort studies

- The studies varied in terms of the types and/or amounts of CFB examined, which included dietary patterns consumed during the complementary feeding period, meat, cereal, foods with different fatty acid composition, sugarsweetened beverages, juice or $100 \%$ juice, and other CFB

- Gaps and limitations in the evidence include the need for randomized controlled trials and studies that examine a wider range of specific types and amounts complementary foods and beverages, account for the rationale for type/amount of complementary foods and beverages given (e.g., reverse causality), and adjust for potential confounders (e.g., human milk and/or formula-feeding and baseline growth status). 


\section{FULL REVIEW}

\section{Systematic review question}

What is the relationship between the types and amounts of complementary foods and beverages consumed and growth, size, and body composition?

\section{Conclusion statement}

Moderate evidence indicates that higher versus lower meat intake or meat versus iron-fortified cereal intake over a short duration ( $-3 \mathrm{mo})$ during the complementary feeding period does not favorably or unfavorably influence growth, size, and/or body composition. There is insufficient evidence to determine a relationship between meat intake and prevalence/incidence of overweight or obesity.

Limited evidence suggests that type or amount of cereal given does not favorably or unfavorably influence growth, size, body composition, and/or prevalence/incidence of overweight or obesity.

Moderate evidence suggests that consumption of complementary foods with different fats and/or fatty acid composition does not favorably or unfavorably influence growth, size, or body composition. There is not enough evidence to determine a relationship between consumption of complementary foods with different fats and/or fatty acid composition and/or prevalence/incidence of overweight or obesity.

Limited evidence suggests that sugar-sweetened beverage consumption during the complementary feeding period is associated with increased risk of obesity in childhood, but is not associated with other measures of growth, size, and body composition.

Limited evidence showed a positive association between juice intake and infant weight-for-length and child BMI z-scores.

No conclusion could be made about the relationship between other complementary foods (vegetables, fruit, dairy products and/or cow's milk, cereal-based products, milk-cereal drink, and/or categories such as "ready-made foods") and growth, size, body composition, and/or prevalence/incidence of overweight or obesity.

No conclusion could be made about the relationship between distinct dietary patterns during the complementary feeding period and growth, size, body composition, and/or prevalence/incidence of malnutrition, overweight or obesity.

\section{Grades}

Moderate - Meat; Different Fats and/or Fatty Acid Composition; Limited - Juice; Sugar-Sweetened Beverages; Grade Not Assignable - Cereal; Other CFB; Dietary Patterns 


\section{Summary}

- This review includes 49 studies that examined the association between types and amounts of complementary foods and beverages (CFB) and growth, size, body composition, and/or overweight or obesity status including:

o 18 randomized controlled trials (RCTs)

o One non-RCT

o 30 prospective cohort studies

- The types and amounts of CFB consumed during the complementary feeding (CF) period that were examined varied across studies. The types of CFB included meat, fortified and unfortified cereal, foods with different fats and/or fatty-acid composition, sugar-sweetened beverages (SSBs), juice drinks and/or 100\% juice, and other CFB (e.g., fruits, vegetables, eggs, fish).

0 Distinct dietary patterns during the CF period were also examined but difficult to compare

o Introduction of specific types of CFB was also examined but varied widely (e.g., SSB <6mo vs. never; ground meat/soy product $<3,4-6$, $>6 \mathrm{mo}$ )

- Growth, size, and body composition outcomes varied across studies. These outcomes included weight, length/height, body circumferences (e.g., head, arm, chest, waist), fat mass (FM), lean mass, weight-to-height ratio (e.g., body mass index (BMI), weight-for-length z-score (WLZ)), and/or incidence/frequency/prevalence/risk of malnutrition, overweight, or obesity measured either at a single time point or change over time.

- The relationship between the types and/or amounts of CFB and growth, size, and/or body composition remains unclear.

o In many cases, the amount of CFB provided would not be expected to affect these outcomes over the limited duration of time in which it was tested or how long after the intervention subjects were followed-up

o Given the normal variation in healthy child growth patterns, caution should be used when interpreting results between timing, types and amounts of CFB and outcomes for individuals based on findings at the population level.

- Additional factors that need to be considered when examining the relationship between types and/or amounts of CFB and growth, size, and/or body composition outcomes include:

o Early infant milk feeding practices (human milk, formula, and/or mixed)

o Variability of normal early infant growth patterns

- Parental feeding styles and the rationale for choosing specific types of CFB (e.g., perceived infant readiness, infant growth or size, fear of inadequate milk supply, sleep promotion, responsive feeding, infant food neophobia/acceptance)

- Cultural preference related to parental history and/or feeding practices

\section{Description of the evidence}

This SR includes 49 studies that examined the association between the types and 
amounts of CFB and growth, size, and body composition. The study designs in this review included 18 RCTs (1-18), one of which was a cross-over design (1), one non-RCT (19), and 30 prospective cohort studies (20-49) (Supplemental Table S1). Multiple articles used the same cohorts but represented different outcomes, different exposures, or exposures/outcomes at different ages $(41,42,40,49,51$, $56,32,50,31,38,39)$.

\section{Description of subject characteristics}

The studies included in this SR enrolled both girls and boys ( $29-67 \%$ females) who were healthy, full-term infants According to the Human Development Index (50), 37 articles were from studies conducted in countries categorized as "very high", and 12 articles were from studies conducted in countries categorized as "high. While most studies did not describe the race/ethnicity of subjects, they were all conducted in representative populations from the countries in which they were conducted.

A number of studies enrolled infants who were exclusively breastfed (EBF $(4,11-15$, $17)$ or exclusively formula-fed (EFF $(1,9)$ up to at least 4 mo of age. The remaining studies varied in terms of whether infants were fed human milk, infant formula, or both and most adjusted for feeding method (e.g., BF duration) in analyses.

\section{Description of types and amounts of complementary foods and beverages}

The types of CFB commonly examined in these studies included meats, fortified and unfortified cereals/porridges, foods that varied in fats or fatty acid profiles, and sugar-sweetened beverages (SSBs), juice drinks, and 100\% fruit juice. In most cases, cereal refers to infant cereals that were fortified with iron (Fe), and variably fortified with additional micronutrients (e.g., zinc). Fewer studies examined other foods and/or food groups such as fruit and/or vegetable snacks, biscuits, fried potatoes, confectionary or sweetened foods, home-based CFB (prepared with a blender according to a provided recipe), and self-made vs. ready-made CFB. Types and amounts of CFB were analyzed in several ways, such as different types of CFB, different amounts of the same CFB, by age of introduction of specific CFB, and dietary patterns during the CF period (Supplemental Table S1).

The included articles were categorized according to how types and/or amounts of CFB were assessed:

- Meat, with or without cereal $(2,3,5,11,14,15,18,32,33,39,44,49)$. These studies examined meat as a CFB, including meat intake compared to another CFB such as cereal, the amount of meat consumed, or meat introduction;

- Cereal $(9,11,17,35,38,49)$. These studies examined cereal(s), including different types of cereal, amount of cereal, or timing of cereal intake. Several articles randomized groups to receive meat vs. cereal, or meat and cereal vs. control. Those studies are not discussed in the "cereal" section to avoid redundancy with the "meat with or without cereal" section;

- CFB with different fats and/or fatty acid composition $(4,6,10,13)$. These studies examined different types of CFB including fish and egg that naturally 
contain or were manipulated to contain different amounts or types of fat;

- SSBs (26, 31-33, 38, 40, 43, 45). These studies examined either amount or timing of SSBs consumed during the CF period;

- Juice drinks and/or 100\% juice (31-33, 38, 43, 45). These studies examined the consumption of juice, which may or may not have contained added sugar. Studies examined the amount or timing of juice, included $100 \%$ juice, juice drinks, and/or other beverages, during the CF period;

- Other CFB $(8,16,19,21,22,27,29,30,32,33,36-38,43,44,48,49)(7,8$, $19,21,22,27,29,30,32,33,36-38,43,44,49)$. These remaining studies examined other or multiple CFB, which were not addressed in the aforementioned categories (e.g., vegetables, ready-made foods, confectionary foods);

- Dietary patterns $(12,20,23-25,27,28,34,41,42,46,47)$. These studies examined dietary patterns during the CF period classified either by observation (e.g., macrobiotic diet) or statistical analyses (e.g., adherence scores for patterns derived from latent class, cluster, or principal component analysis).

\section{Description of growth, size, and body composition outcomes}

Outcomes that were reported in relation to types and amounts of CFB consumed included growth, size, and body composition at various ages, ranging from birth to 42 y (Supplemental Table S1). The majority of studies reported that standard procedures were used to obtain weight and height (e.g., measured from calibrated scales/stadiometers) and were assessed within the first two years of life (1, 3-9, 11, $12,14,15,18,19,23,24,28,36,39,48)$. However, a few studies obtained weight and/or length or height via maternal-report $(31,42,47,49)$, clinical records $(2,37)$, unstandardized or various methods $(38,44)$, or did not specifically report their methods $(10,13,17,20)$.

Nineteen studies determined BMI, BMI trajectory, BMIZ, and/or WLZ from measured $(5,9,14,15,21,25,28,29,32-34,38,41,43,45)$ or reported $(42,44$, $47,49)$, weight and length. Eleven studies assessed adiposity according to fat mass (FM) and/or lean mass measured by skinfold thickness $(3,4,22,23,28,30,36)$ (9),or whole-body dual-energy X-ray apsorptiometry (DXA) (41),(48),(29). Six studies assessed central adiposity, either waist circumference (WC) or abdominal fat $(14,26,29,33,34,44)$ measured using flexible tape $(26,33,34)$, ultrasound (29), self-report (44), or non-specified methods (14). Fourteen studies reported head circumference (HC) $(1,4,5,7,9-12,15,18,24,28,36,39)$ and six reported mid-upper arm circumference (MUAC) $(1,3,7,12,28,36)$. Seven studies assessed overweight or obesity $(20,26,29,40,42,44,49)$, using standards according to BMI or WLZ. Two studies assessed malnutrition outcomes (e.g., wasting, stunting) (28, 46).

\section{Evidence synthesis}

Results from the included studies are described according to specific CFB in Tables 1-6, placed after each respective section. Twenty-four of the 49 articles reported 
one or more significant associations, either positive, negative, or mixed, between types or amounts of CFB and growth, size, body composition, and/or risk of malnutrition, overweight or obesity $(5,14,15,19,21,23,27,28,30-34,37-42$, 44$47,49)$. Twenty-five of the 49 articles found no relationship between types and amounts of CFB and growth, size, body composition, and/or risk of overweight or obesity $(1-4,6-13,16-18,20,22,24-26,29,35,36,43,48)$.

\section{Meat}

Twelve articles, including seven RCTs $(2,3,5,11,14,15,18)$ and five articles from four observational studies $(32,33,39,44,49)$ examined the relationship between meat intake and growth, size, body composition, and/or risk of overweight or obesity outcomes. Studies varied in terms of whether they assessed meat compared to cereal, meat and cereal compared to controls, or the amount of meat consumed (see Table 1).

Krebs et al. (5) reported that BF infants consuming meat compared to Fe-fortified cereal from 5-7 mo had a significantly greater rate of $\mathrm{HC}$ growth from 7-12 mo, but no significant differences in $\mathrm{HC}$ growth 4-7 mo, weight-for-length 4-7 mo or 7-12 mo, weight growth rate at 4-7 mo or 7-12 mo, WAZ 4-12 mo, length growth rate 4-7 mo or 7-12 mo, or LAZ 4-12 mo. Tang et al. (15) reported that Chinese infants randomly assigned to the meat vs. cereal groups had a smaller decline in WAZ, smaller decline in LAZ and greater increase in length from 6-18 mo but no significant differences in WLZ or in $\mathrm{HC}$, or HC z-score from 6-18 mo. Tang and Krebs (14) also reported that U.S. infants randomly assigned to meat vs. cereal groups had significantly greater mean change in WAZ and LAZ from 5-9 mo, but there were no differences between groups in WLZ or BMIZ from 5-9 mo or in WC at 9 mo of age. In two other RCTs, there were no significant group differences in weight, length, or $\mathrm{HC}$ in the first year of life between those who received meat and Fe-fortified cereal relative to control groups $(11,18)$.

Two RCTs found no relationship between amount of meat consumed and growth, size, or body composition outcomes prior to 10 mo of age $(2,3)$. Three articles from two observational studies also examined meat intake (32, 33, 39). Garden et al. (33) and Garden et al. (32) reported significant positive associations between meat intake at 18 mo and BMI trajectory (i.e., 'early and persistent', 'late increase', or 'normal' according to CDC percentile curves) at different ages, 8 y and birth-11.5 y (in boys only). Morgan et al. (39) found that meat intake from 4-12 mo was significantly associated with higher weight gain from 4-12 mo but this did not persist in the fully-adjusted models or at older age intervals (4-16 mo, 4-24 mo), and there was no association with length or HC outcomes.

Meat introduction. Two observational studies examined the introduction of meat (44, 49). Zheng et al. (49) reported no significant association between age of ground meat/soy introduction and overweight or obesity or BMl at age 4-5 y. SchackNielsen et al. (44) found that, among other relationships identified, later introduction of meat was associated with decreased BMI and risk of overweight at $42 \mathrm{y}$, but not at 20-34 y of age. 
Table 1. Studies that examined meat, with or without cereal, and growth, size, and body composition

\begin{tabular}{|c|c|c|c|c|c|c|}
\hline $\begin{array}{l}\text { Reference }^{1} \text {, } \\
\text { country, analytic } \\
\mathrm{N}\end{array}$ & $\begin{array}{l}\text { Independent } \\
\text { variable/exposure }^{2}\end{array}$ & $\begin{array}{l}\text { Results for } \\
\text { weight status }\end{array}$ & $\begin{array}{l}\text { Results for body } \\
\text { composition }\end{array}$ & $\begin{array}{l}\text { Results for } \\
\text { weight }\end{array}$ & $\begin{array}{l}\text { Results for } \\
\text { length/height }\end{array}$ & $\begin{array}{l}\text { Results for head } \\
\text { circumference }\end{array}$ \\
\hline $\begin{array}{l}\text { Dube et al., } 2010 \\
\text { (2) RCT; } \\
\text { Germany } \\
\text { N: } 97\end{array}$ & $\begin{array}{l}\text { Low meat group: } \\
\text { meals } 8 \% \text { meat by } \\
\text { weight for } 7 \mathrm{mo} \text {, } \\
\text { ages } 4-11 \text { mo vs. } \\
\text { High meat group: } \\
\text { meals } 12 \% \text { meat by } \\
\text { weight for } 7 \text { mo, } \\
\text { ages } 4-11 \text { mo }\end{array}$ & & & $\begin{array}{l}\text { Weight at 4, 7, or } \\
\text { 10mo, NSGD }\end{array}$ & & \\
\hline $\begin{array}{l}\text { Engelmann et } \\
\text { al., } 1998 \text { (3) } \\
\text { RCT; Denmark } \\
\text { N: } 41\end{array}$ & $\begin{array}{l}\text { Low meat group: } \\
\text { puree with } 10 \mathrm{~g} / \mathrm{d} \text { of } \\
\text { meat for } 2 \mathrm{mo} \text {, ages } \\
8-10 \mathrm{mo} \text { vs. } \\
\text { High meat group: } \\
\text { puree with } 27 \mathrm{~g} / \mathrm{d} \text { of } \\
\text { meat for } 2 \mathrm{mo}, \text { ages } \\
\text { 8-10mo }\end{array}$ & & $\begin{array}{l}\text { Change in MUAC } \\
\text { or triceps skinfold } \\
\text { thickness at } \\
10 \mathrm{mo}, \mathrm{NSGD}\end{array}$ & $\begin{array}{l}\text { Change in } \\
\text { weight at 10mo, } \\
\text { NSGD }\end{array}$ & $\begin{array}{l}\text { Change in crown- } \\
\text { heel length at } \\
10 \mathrm{mo}, \mathrm{NSGD}\end{array}$ & \\
\hline $\begin{array}{l}\text { Garden et al., } \\
2011 \text { (33) } \\
\text { Australia } \\
\text { N: } 362 \text { (339 WC) }\end{array}$ & $\begin{array}{l}\text { Meat intake (g, \% } \\
\text { energy) at 18mo; } \\
\text { e.g., chicken } \\
\text { nuggets, ground } \\
\text { beef, beef } \\
\text { sausages, ham }\end{array}$ & & $\begin{array}{l}\text { BMI at 8y: g, } \\
\beta=0.25 ; 95 \% \\
C l: 0.04,0.45 \\
P=0.02 ; \% \\
\text { energy, } \beta=0.27 ; \\
95 \% \mathrm{Cl}: 0.07 \\
0.47, P=0.01 ; \\
\text { WC at } 8 y: g \\
\beta=0.59 ; 95 \% \\
C l: 0.03,1.15 \\
P=0.04 ; \% \\
\text { energy, } \beta=0.63 ; \\
95 \% C l: 0.10 \\
1.17, P=0.02\end{array}$ & & & \\
\hline
\end{tabular}




\begin{tabular}{|c|c|c|c|c|c|}
\hline \multirow[t]{2}{*}{$\begin{array}{l}\text { Garden et al., } \\
2012 \text { (32) } \\
\text { Australia } \\
\text { N: } 298\end{array}$} & $\begin{array}{l}\text { In boys, meat } \\
\text { intake (g, \% } \\
\text { energy) at 18mo; } \\
\text { e.g., chicken } \\
\text { nuggets, ground } \\
\text { beef, beef } \\
\text { sausages, ham }\end{array}$ & $\begin{array}{l}\text { Early and } \\
\text { Persistent vs. } \\
\text { Normal or Late } \\
\text { Increase BMI } \\
\text { from } 0-11.5 y: \text { g, } \\
\text { median } 38.8 \text { vs. } \\
18.6 \text { vs. } 24.1 \text {, } \\
\mathrm{P}=0.01 ; \% \\
\text { energy, } 9.2 \text { vs. } \\
4.4 \text { or } 4.1, \mathrm{P}=0.01\end{array}$ & & & \\
\hline & $\begin{array}{l}\text { In girls, meat intake } \\
\text { (g, \% energy) at } \\
\text { 18mo; e.g., chicken } \\
\text { nuggets, ground } \\
\text { beef, beef } \\
\text { sausages, ham }\end{array}$ & $\begin{array}{l}\text { Any BMI from 0- } \\
11.5 y, \text { NSA }\end{array}$ & & & \\
\hline $\begin{array}{l}\text { Krebs et al., } 2006 \\
\text { (5) } \\
\text { RCT; U.S. } \\
\text { N: } 72\end{array}$ & $\begin{array}{l}\text { Meat group: pureed } \\
\text { beef for } 2 \mathrm{mo} \text {, ages } \\
5-7 \mathrm{mo} \\
\text { Cereal group: Fe- } \\
\text { fortified infant } \\
\text { cereal for } 2 \mathrm{mo}, \\
\text { ages } 5-7 \mathrm{mo} \text { ( } 1: 2 \\
\text { ratio of cereal to } \\
\text { human milk/water) }\end{array}$ & $\begin{array}{l}\text { Mean weight-for- } \\
\text { length percentiles } \\
\text { at either } 4-7 \text { mo or } \\
7-12 \text { mo intervals, } \\
\text { NSGD }\end{array}$ & $\begin{array}{l}\text { Weight growth } \\
\text { rate from 4-7mo, } \\
\text { or from 7-12mo, } \\
\text { or WAZ from 4- } \\
12 \mathrm{mo}, \text { NSGD }\end{array}$ & $\begin{array}{l}\text { Length growth rate } \\
\text { from } 4-7 \mathrm{mo} \text {, or } \\
\text { from } 7-12 \mathrm{mo} \text {, or } \\
\text { LAZ from 4-12mo, } \\
\text { NSGD }\end{array}$ & $\begin{array}{l}\text { HC growth from } 7- \\
\text { 12mo: } 0.48, \text { SE: } \\
0.018 \text { vs. } 0.41, \text { SE: } \\
0.019, P=0.02 ; \text { from } \\
\text { 4-7mo, NSGD }\end{array}$ \\
\hline $\begin{array}{l}\text { Makrides et al., } \\
1998 \text { (11) } \\
\text { RCT; Australia } \\
\text { N: } 62 \\
\text { (Intervention, 36; } \\
\text { Control, 26) }\end{array}$ & $\begin{array}{l}\text { Meat+cereal group: } \\
4,30-40 \mathrm{~g} \\
\text { servings/wk of red } \\
\text { meat and } 4,113 \mathrm{~g} \\
\text { jars/wk of Fe- } \\
\text { fortified cereal for } \\
2 \mathrm{mo}, \text { ages } 4-6 \mathrm{mo} \\
\text { Control group: } \\
\text { Standard nutritional } \\
\text { advice to consume } \\
\text { Fe-fortified infant } \\
\text { cereal for } 2 \text { mo, }\end{array}$ & & $\begin{array}{l}\text { Weight at } 9 \text { or } \\
12 \mathrm{mo}, \text { NSGD }\end{array}$ & $\begin{array}{l}\text { Length at } 9 \text { or } \\
12 \mathrm{mo}, \mathrm{NSGD}\end{array}$ & $\begin{array}{l}\mathrm{HC} \text { at } 9 \text { or } 12 \mathrm{mo} \text {, } \\
\text { NSGD }\end{array}$ \\
\hline
\end{tabular}




\begin{tabular}{|c|c|c|c|c|c|c|}
\hline & ages 4-6mo & & & & & \\
\hline \multirow[t]{3}{*}{$\begin{array}{l}\text { Morgan et al., } \\
2004 \text { (39) } \\
\text { U.K. } \\
\text { N: } 144\end{array}$} & $\begin{array}{l}\text { Meat intake: red } \\
\text { (beef, pork and } \\
\text { lamb) and white } \\
\text { (chicken, turkey, } \\
\text { fish) meat from } \\
\text { age 4-12mo }\end{array}$ & & & $\begin{array}{l}\text { Weight gain 4- } \\
\text { 12mo: } \beta=0.40 \text {, } \\
95 \% \mathrm{Cl}: 0.005 \text {, } \\
0.79, \mathrm{P}=0.05 \\
\text { effect } \\
\text { disappeared } \\
\text { after adjusting } \\
\text { for protein } \\
\text { intake, NSA }\end{array}$ & $\begin{array}{l}\text { Length 4-12mo, } \\
\text { NSA }\end{array}$ & $\mathrm{HC} 4-12 \mathrm{mo}, \mathrm{NSA}$ \\
\hline & $\begin{array}{l}\text { Meat intake: red } \\
\text { (beef, pork and } \\
\text { lamb) and white } \\
\text { (chicken, turkey, } \\
\text { fish) meat from } \\
\text { age 4-16mo }\end{array}$ & & & $\begin{array}{l}\text { Weight 4-16mo, } \\
\text { NSA }\end{array}$ & $\begin{array}{l}\text { Length 4-16mo, } \\
\text { NSA }\end{array}$ & $\mathrm{HC} 4-16 \mathrm{mo}, \mathrm{NSA}$ \\
\hline & $\begin{array}{l}\text { Meat intake: red } \\
\text { (beef, pork and } \\
\text { lamb) and white } \\
\text { (chicken, turkey, } \\
\text { fish) meat from } \\
\text { age 4-24mo }\end{array}$ & & & $\begin{array}{l}\text { Weight 4-24mo, } \\
\text { NSA }\end{array}$ & $\begin{array}{l}\text { Length 4-24mo, } \\
\text { NSA }\end{array}$ & $\mathrm{HC} 4-24 \mathrm{mo}, \mathrm{NSA}$ \\
\hline \multirow[t]{2}{*}{$\begin{array}{l}\text { Schack-Nielsen } \\
\text { et al., } 2010 \text { (44) } \\
\text { Denmark } \\
\text { N: } 5068\end{array}$} & $\begin{array}{l}\text { Meat introduction } \\
\text { continuous, mo }\end{array}$ & $\begin{array}{l}\text { At 42y, } \\
\text { Overweight OR } \\
0.93,95 \% \mathrm{Cl} \text { : } \\
0.87,1.00, \\
\mathrm{P}=0.044 ; \\
\text { Obesity, NSA }\end{array}$ & $\begin{array}{l}\text { BMIZ at ages: } \\
42 \mathrm{y} \beta=-0.032, \\
95 \% \mathrm{Cl}:-0.059,- \\
0.005 ; 20-34 \mathrm{y}, \\
\text { NSA }\end{array}$ & & & \\
\hline & $\begin{array}{l}\text { Meat introduction } \\
\geq 4 \text { vs. }<4 \mathrm{mo}\end{array}$ & $\begin{array}{l}\text { Overweight at } \\
42 \mathrm{y}, \mathrm{NSA}\end{array}$ & & & & \\
\hline $\begin{array}{l}\text { Tang et al., } 2014 \\
\text { (15) } \\
\text { RCT; China } \\
\text { N: } 1318\end{array}$ & $\begin{array}{l}\text { Meat group: boiled } \\
\text { pork for } 12 \mathrm{mo} \text {, } \\
\text { ages 6-18mo vs. } \\
\text { Cereal group: } \\
\text { commercial rice } \\
\text { cereal product for }\end{array}$ & & $\begin{array}{l}\text { Change in WLZ } \\
\text { from } 6-18 \mathrm{mo}, \\
\text { NSGD }\end{array}$ & $\begin{array}{l}\text { Mean change in } \\
\text { WAZ from } 6- \\
\text { 18mo: }-0.35, \text { SD: } \\
0.60 \text { vs. }-0.43, \\
\text { SD: } 0.61 \text {, } \\
P=0.05 \text {. Change }\end{array}$ & $\begin{array}{l}\text { Mean change in } \\
\text { LAZ from } 6-18 m o: \\
-0.43, \text { SD: } 0.72 \text { vs. } \\
-0.54, \text { SD: } 0.67 \text {, } \\
\text { P<0.01. Length } \\
\text { from 6-18mo, }\end{array}$ & $\begin{array}{l}\text { Change in } \mathrm{HC} \text { or } \\
\text { HCZ from 6-18mo, } \\
\text { NSGD }\end{array}$ \\
\hline
\end{tabular}




$12 \mathrm{mo}$, ages 6-
$18 \mathrm{mo}$

$12 \mathrm{mo}$, ages 6-
$18 \mathrm{mo}$

Meat group: pureed

Tang and Krebs,
2014 (14)
RCT; U.S.
N: 42

meat and gravy for

4mo, ages $\sim 5-9 \mathrm{mo}$

vs. Cereal group:

Fe or FeZn-fortified

infant cereal for

4mo, ages -5-9mo;

asked to avoid

meats

\section{in weight from 6- $13.01 \mathrm{~cm}, \mathrm{SD}: 1.9$ \\ 18mo, NSGD \\ vs. $12.75 \mathrm{~cm}, \mathrm{SD}$}

$1.8, P=0.01$

WLZ or BMIZ

from 5 to $9 \mathrm{mo}$,

Mean change in

WAZ 5-9mo:

NSGD; WC at

0.24 , SD: 0.19

vS. $-0.07, \mathrm{SD}$

$0.17, \mathrm{P}<0.05$

Mean change in

LAZ 5-9mo: 0.14

9mo, NSGD

Meat+cereal group

pureed meat and

Fe-fortified infant

$\begin{array}{ll}\mathrm{RCT} \text {; Canada } & \text { Fe-fortified infant } \\ \mathrm{N}: 103 & \text { cereals for } 6 \mathrm{mo} \text {, } \\ \text { (Intervention 49; } & \text { ages } 6-12 \mathrm{mo} \text {; }\end{array}$

$\begin{array}{ll}\text { (Intervention, 49; } & \text { ages } 6-12 \mathrm{mo} \text {, all } \\ \text { Control, 54) } & \text { other foods allowed }\end{array}$

at parents'

discretion except

vitamin/mineral

supplements

containing Fe and

Fe-fortified

formulas vs.

Control group: no

dietary intervention

\begin{tabular}{lll}
\hline Zheng et al., & Meat/soy & $\begin{array}{l}\text { Overweight or } \\
\text { introduction: } \leq 3,4-\end{array}$ \\
$\begin{array}{ll}\text { obesity at 4-5y, } \\
\text { China }\end{array}$ & $6,>6 \mathrm{mo}$ & NSA \\
N: 40,510 & &
\end{tabular}

1. All studies followed a prospective cohort design unless noted as RCT or non-RCT

2. The independent variable/exposure of interest included types and/or amounts of CFB, which encompassed dietary patterns during the complementary feeding period and timing of specific CFB; this section of studies examined meat with or without cereal.

3. Outcomes were organized for practicality into columns: weight status, body composition, weight, length or height, and head circumference. 
Results described in the respective columns are based on outcome similarity and in accordance with the analytical framework as follows: Weight status included risk/incidence/prevalence/frequency of malnutrition, healthy weight, overweight, or obesity; Body composition included measures, indices, and proxies of overall adiposity such as lean mass, fat mass (FM), \% body fat, weight-to-height ratios such as BMI, BMIZ, WLZ, central adiposity or waist circumference, and arm or thigh circumferences; Weight included weight-specific measures such as weight-for-age z-score (WAZ), Length or Height included length-specific measures such as length-for-age z-score (LAZ); Head circumference included head circumference

Abbreviations: BF, breast-fed; BMIZ, BMI Z-score; CFB, complementary food/beverage; Fe, iron; FF, formula-fed; HC, head circumference; $\mathrm{HCZ}$, head circumference Z-score; LAZ, length for age z-score; MUAC, mid-upper arm circumference; NR, not reported; NSA, no significant association; NSGD, no significant group differences; RCT, randomized controlled trial; WAZ, weight for age z-score; WC, waist circumference; WLZ, weight for length Z-score; Zn, zinc 


\section{Cereal}

The studies that examined cereal and meat intake or compared cereal intake relative to meat intake are discussed in the previous section. Three articles from RCTs examined cereal as a CFB in relation to multiple outcomes, including body composition, weight, length, and $\mathrm{HC}$ prior to $18 \mathrm{mo}$ of age $(1,9,17)$ (see Table 2). Davidsson et al. (1) reported no differences in a cross-over trial with EFF infants receiving specially-developed weaning cereals that were fortified to match commercially-available fortified cereals made with wheat/soy or wheat/milk for 4 wk each and weight, length, $\mathrm{HC}$, or arm or chest circumference at 7-17 wk. Lonnderdal and Chen (9) reported no differences between EFF infants receiving $25 \mathrm{~g} / \mathrm{d}$ of cereal (fortification not specified) vs. no cereal from age 4-7 mo and weight-for-height, skinfold thickness, weight gain, length gain, or $\mathrm{HC}$ from 4-7 mo of age. Walter et al. (17) reported no differences between EBF infants, who were randomized at 4 mo to receive $30 \mathrm{~g} / \mathrm{d}$ of Fe-fortified vs. non-fortified cereal, in weight or length at 8,12 , or 15 mo of age.

Three articles from observational studies $(35,38,49)$ also examined the relationship between cereal as a CFB and growth, size, body composition, and/or risk of overweight or obesity outcomes (see Table 3). Hertrampf et al. (35) reported no significant differences between infants consuming Fe-fortified cereal compared to routine CFB (including cereal that was not specified as fortified) from $\sim 3-6$ mo and weight at 8 or $12 \mathrm{mo}$ of age. Using data from the PROBIT trial, Kramer et al. (38) found that any intake of cereal (non-fortified adult' cereals) vs. none at 3 mo of age was associated with lower WAZ, LAZ and HC from 3-6 mo of age, but not with WLZ at any time point (38). Kramer et al. (38) reported no significant associations between cereal intake and outcomes at either 6-9 mo or 9-12 mo of age. Finally, Zheng et al. (49) found no significant associations between introduction to rice cereal/porridge and risk of either overweight or obesity at age 4-5 $\mathrm{y}$. 
Table 2. Studies that examined cereal, and growth, size, and body composition

\begin{tabular}{|c|c|c|c|c|c|c|}
\hline $\begin{array}{l}\text { Reference }^{1}, \\
\text { country, } \\
\text { analytic } \mathbf{N}\end{array}$ & Independent variable/exposure ${ }^{2}$ & $\begin{array}{l}\text { Results for } \\
\text { weight } \\
\text { status }\end{array}$ & $\begin{array}{l}\text { Results for } \\
\text { body } \\
\text { composition }\end{array}$ & $\begin{array}{l}\text { Results for } \\
\text { weight }\end{array}$ & $\begin{array}{l}\text { Results for } \\
\text { length/height }\end{array}$ & $\begin{array}{l}\text { Results for } \\
\text { head } \\
\text { circumference }\end{array}$ \\
\hline $\begin{array}{l}\text { Davidsson } \\
\text { et al., } 1996 \\
\text { (1) } \\
\text { RCT; } \\
\text { Scotland } \\
\text { N: } 57\end{array}$ & $\begin{array}{l}\text { FF infants received each cereal ad } \\
\text { lib for } 4 \text { wk each at ages } 7-17 \mathrm{wk} \text { : } \\
\text { wheat/soy: } 1.8-8 \% \text { fiber vs. } \\
\text { wheat/milk: } 2-5.3 \% \text { fiber }\end{array}$ & & $\begin{array}{l}\text { Arm or chest } \\
\text { circumference at } \\
7-17 \mathrm{wk}, \mathrm{NSA}\end{array}$ & $\begin{array}{l}\text { Weight at 7- } \\
17 \mathrm{wk}, \mathrm{NSA}\end{array}$ & $\begin{array}{l}\text { Length at } 7- \\
17 \mathrm{wk}, \mathrm{NSA}\end{array}$ & $\begin{array}{l}\mathrm{HC} \text { at 7-17wk, } \\
\text { NSA }\end{array}$ \\
\hline $\begin{array}{l}\text { Hertrampf } \\
\text { et al., } 1990 \\
\text { (Hertrampf, } \\
\text { 1990) } \\
\text { Chile } \\
\text { N: } 1894 \mathrm{mo} ; \\
18712 \mathrm{mo}\end{array}$ & $\begin{array}{l}\text { Fe-fortified cereal: received } 20 \mathrm{~g} / \mathrm{d} \\
\text { at } 4 \mathrm{mo} \text { and } 40 \mathrm{~g} / \mathrm{d} \text { at } 6 \mathrm{mo} \\
\text { vs. Control: routine CFB }\end{array}$ & & & $\begin{array}{l}\text { Weight-for-age } \\
\text { adequacy at } 8 \text {, } \\
\text { or } 12 \mathrm{mo}, \mathrm{NSA}\end{array}$ & & \\
\hline $\begin{array}{l}\text { Kramer et } \\
\text { al., } 2004 \\
(38) \\
\text { Belarus } \\
\text { N: } 17,046\end{array}$ & $\begin{array}{l}\text { Cereal intake (any vs. none) at } \\
\text { ages } 3,6 \text {, or } 9 \text { mo }\end{array}$ & & WLZ 3-6, NSA & $\begin{array}{l}\text { WAZ 3-6mo, } \beta=- \\
0.293,95 \% \mathrm{Cl}:- \\
0.386,-0.199 \\
P=N R\end{array}$ & $\begin{array}{l}\text { LAZ 3-6mo, } \beta=- \\
0.240,95 \% \text { Cl: }- \\
0.353,-0.127 \\
P=N R\end{array}$ & $\begin{array}{l}\mathrm{HC} 3-6 \mathrm{mo}, \beta=- \\
0.291,95 \% \mathrm{Cl}:- \\
0.463,-0.120 \\
P=N R\end{array}$ \\
\hline $\begin{array}{l}\text { Lonnerdal } \\
\text { and Chen., } \\
1990(9) \\
\text { RCT; China } \\
\text { N: NR }\end{array}$ & $\begin{array}{l}\text { EFF infants vs. FF+cereal for } 3 \mathrm{mo} \text {, } \\
\text { ages } 4-7 \mathrm{mo}\end{array}$ & & $\begin{array}{l}\text { Weight-for- } \\
\text { length from 4- } \\
\text { 7mo, NSGD; } \\
\text { Skinfold } \\
\text { thickness, data } \\
\text { NR, NSGD }\end{array}$ & $\begin{array}{l}\text { Weight gain } \\
\text { from } 4-7 \mathrm{mo} \text {, } \\
\text { NSGD }\end{array}$ & $\begin{array}{l}\text { Length gain from } \\
4-7 \mathrm{mo}, \mathrm{NSGD}\end{array}$ & $\begin{array}{l}\text { HC from 4-7mo, } \\
\text { data NR, NSGD }\end{array}$ \\
\hline $\begin{array}{l}\text { Walter et } \\
\text { al., } 1993 \\
(17) \\
\text { RCT; Chile } \\
\text { N: } 444 \\
8 \mathrm{mo} ; 370 \\
\text { 12mo; } 340\end{array}$ & $\begin{array}{l}\text { Fe-fortified cereal + breastmilk vs. } \\
\text { Unfortified cereal + breastmilk, age } \\
\text { 4-15mo }\end{array}$ & & & $\begin{array}{l}\text { Weight at } 8,12 \text {, } \\
\text { or } 15 \mathrm{mo}, \mathrm{NSGD}\end{array}$ & $\begin{array}{l}\text { Length at } 8,12 \text {, } \\
\text { or } 15 \mathrm{mo}, \mathrm{NSGD}\end{array}$ & \\
\hline
\end{tabular}




\begin{tabular}{llll}
\hline $15 \mathrm{mo}$ & & \\
\hline Zheng et & Rice cereal/porridge introduction: & Overweight & BMI at 4-5y, \\
al., 2015 & $\leq 3,4-6,>6 \mathrm{mo}$ & or obesity at & NSA \\
(49) & & $4-5 y$, NSA & \\
China & & \\
N: 40,510 & & &
\end{tabular}

1. All studies followed a prospective cohort design unless noted as randomized controlled trial (RCT) or non-RCT.

2. The independent variable/exposure of interest included types and/or amounts of CFB, which encompassed dietary patterns during the complementary feeding period and timing of specific CFB; this section of studies examined cereal.

3. Outcomes were organized for practicality into columns: weight status, body composition, weight, length or height, and head circumference. Results described in the respective columns are based on outcome similarity and in accordance with the analytical framework as follows: Weight status included risk/incidence/prevalence/frequency of malnutrition, healthy weight, overweight, or obesity; Body composition included measures, indices, and proxies of overall adiposity such as lean mass, fat mass (FM), \% body fat, weight-to-height ratios such as BMI, BMIZ, WLZ, central adiposity or waist circumference, and arm or thigh circumferences; Weight included weight-specific measures such as weight-for-age z-score (WAZ), Length or Height included length-specific measures such as length-for-age z-score (LAZ); Head circumference included head circumference

Abbreviations: BF, breast-fed; CFB, complementary food/beverage; EFF, exclusively formula-fed; Fe, iron; FF, formula-fed; HC, head circumference; LAZ, length for age z-score; NR, not reported; NSA, no significant association; NSGD, no significant group differences; RCT, randomized controlled trial; WAZ, weight for age z-score; WLZ, weight for length z-score 


\section{CFB with different fat/fatty acid composition}

Table 3 describes results from 4 RCTs, which examined the influence of CFB that varied in fatty acid profiles $(4,6,10,13)$. No relationship was found between groups consuming CFB that differed in fatty acid content with respect to growth, size, or body composition outcomes. Hoffman et al. (4) found no significant differences between infants randomly assigned to receive one jar/d of CFB with or without eggyolk for $6 \mathrm{mo}$ (ages 6-12 mo) in weight, length, skinfold thickness, or HC at 6, 9, or $12 \mathrm{mo}$ of age. Libuda et al. (6) randomly assigned infants to receive rapeseed oil, salmon, or corn-oil from 4-10 mo, but found no differences between groups in weight or length at 10 mo of age. Makrides et al. (10) randomly assigned infants (BF and/or FF) to consume eggs ( 4/wk, regular or omega-3 enriched) or receive no dietary intervention for $6 \mathrm{mo}$, and reported no differences in weight, length, or $\mathrm{HC}$ at 12 mo of age. Schwartz et al. (13) found no significant differences between infants randomly assigned to receive one jar/d of CFB with either rapeseed oil vs. corn oil with respect to weight at 10 mo or weight gain from 4 to 10 mo of age. 
Table 3. Studies that examined CFB with different fats/fatty acid composition and growth, size, and body composition

\begin{tabular}{|c|c|c|c|c|c|c|}
\hline $\begin{array}{l}\text { Reference }^{1} \text {, } \\
\text { country, } \\
\text { analytic N }\end{array}$ & Independent variable/exposure ${ }^{2}$ & $\begin{array}{l}\text { Results for } \\
\text { weight } \\
\text { status }\end{array}$ & $\begin{array}{l}\text { Results for } \\
\text { body } \\
\text { composition }\end{array}$ & $\begin{array}{l}\text { Results for } \\
\text { weight }\end{array}$ & $\begin{array}{l}\text { Results for } \\
\text { length/height }\end{array}$ & $\begin{array}{l}\text { Results for } \\
\text { circumference }\end{array}$ \\
\hline $\begin{array}{l}\text { Hoffman et } \\
\text { al., } 2004 \\
\text { (Hoffman, } \\
2004 \text { ) } \\
\text { RCT; U.S. } \\
\text { N: } 51\end{array}$ & $\begin{array}{l}\text { DHA-enriched group: CFB } \\
\text { enriched with DHA from egg-yolk, } \\
\text { ages } 6-12 \text { mo vs. Control: } \\
\text { unenriched CFB, ages } 6-12 \text { mo }\end{array}$ & & $\begin{array}{l}\text { Skinfold } \\
\text { thickness at } 6,9 \text {, } \\
\text { or } 12 \mathrm{mo}, \text { NSGD }\end{array}$ & $\begin{array}{l}\text { Weight at } 6,9 \text {, } \\
\text { or } 12 \mathrm{mo}, \mathrm{NSGD}\end{array}$ & $\begin{array}{l}\text { Length at } 6,9 \text {, } \\
\text { or } 12 \mathrm{mo}, \mathrm{NSGD}\end{array}$ & $\begin{array}{l}\mathrm{HC} \text { at } 6,9, \text { or } \\
12 \mathrm{mo}, \mathrm{NSGD}\end{array}$ \\
\hline $\begin{array}{l}\text { Libuda et } \\
\text { al., } 2015 \text { (6) } \\
\text { RCT; } \\
\text { Germany } \\
\text { N: 155-158 }\end{array}$ & $\begin{array}{l}\text { Rapeseed oil (ALA) group: CFB } \\
\text { with rapeseed oil, ages 4-10mo } \\
\text { vs. Fish group: Salmon 2x/wk } \\
\text { (preformed DHA), ages 4-10mo vs. } \\
\text { Corn oil (LA) group: CFB with corn } \\
\text { oil, ages 4-10mo }\end{array}$ & & & $\begin{array}{l}\text { Weight at 10mo, } \\
\text { NSGD }\end{array}$ & $\begin{array}{l}\text { Length at 10mo, } \\
\text { NSGD }\end{array}$ & \\
\hline $\begin{array}{l}\text { Makrides et } \\
\text { al., } 2002 \\
(10) \\
\text { RCT; } \\
\text { Australia } \\
\text { N: } 137\end{array}$ & $\begin{array}{l}\text { Regular egg group: } 4 \text { eggs/wk for } \\
6 \mathrm{mo} \text {, ages 6-12mo; vs. n-3 egg } \\
\text { group: } 4 \text { DHA-enriched eggs/wk } \\
\text { for 6mo, ages 6-12mo; vs. Control } \\
\text { group: Standard weaning diet of } \\
\text { choice for 6mo, ages 6- } 12 \mathrm{mo}\end{array}$ & & & $\begin{array}{l}\text { Weight at } 12 \mathrm{mo} \text {, } \\
\text { NSGD }\end{array}$ & $\begin{array}{l}\text { Length at } 12 \mathrm{mo} \text {, } \\
\text { NSGD }\end{array}$ & $\begin{array}{l}\mathrm{HC} \text { at } 12 \mathrm{mo}, \\
\text { NSGD }\end{array}$ \\
\hline $\begin{array}{l}\text { Schwartz et } \\
\text { al., } 2009 \\
(13) \\
\text { RCT; } \\
\text { Germany } \\
\text { N: } 102\end{array}$ & $\begin{array}{l}\text { Rapeseed oil group: meat-based } \\
\text { CFB with LA/ALA ratio of } 3.9 \text { for } \\
6 \mathrm{mo} \text {, ages } 4-10 \mathrm{mo} \text {; vs. Corn oil } \\
\text { group (control): meat-based CFB } \\
\text { with LA/ALA ratio of } 35.7 \text { for } 6 \mathrm{mo} \text {, } \\
\text { ages 4-10mo }\end{array}$ & & & $\begin{array}{l}\text { Weight at 10mo } \\
\text { or gain from 4- } \\
\text { 10mo, NSGD }\end{array}$ & & \\
\hline
\end{tabular}

1. All studies, except those noted as RCT or non-RCT, followed a prospective cohort design

2. The independent variable/exposure of interest included types and/or amounts of CFB, which encompassed dietary patterns during the complementary feeding period and timing of specific CFB; this section of studies examined CFB with either different fats or fatty acid composition.

3. Outcomes were organized for practicality into columns: weight status, body composition, weight, length or height, and head circumference. 
Results described in the respective columns are based on outcome similarity and in accordance with the analytical framework as follows:

Weight status included risk/incidence/prevalence/frequency of malnutrition, healthy weight, overweight, or obesity; Body composition included measures, indices, and proxies of overall adiposity such as lean mass, fat mass (FM), \% body fat, weight-to-height ratios such as BMI, BMIZ,

WLZ, central adiposity or waist circumference, and arm or thigh circumferences; Weight included weight-specific measures such as weight-forage z-score (WAZ), Length or Height included length-specific measures such as length-for-age z-score (LAZ); Head circumference included head circumference

Abbreviations: ALA, alpha-linolenic acid; BF, breast-fed; CFB, complementary food/beverage; DHA, docosahexaenoic acid; FF, formula-fed; HC, head circumference; LA, linoleic acid; NR, not reported; NSA, no significant association; NSGD, no significant group differences; RCT, randomized controlled trial 


\section{SSBs.}

Five articles examined SSB intake (26, 32, 33, 40, 43) (see Table 4). One article reported that any vs. no intake of SSBs, including during infancy was associated with higher prevalence of obesity at age 6 y and that higher frequency of SSB intake ( $\geq 3 /$ wk vs. never) at age 10-12 mo was associated with a 2-fold increase in odds of obesity at age 6 y (40). In addition, SSB introduction before age 6 mo vs. never during infancy was associated with 92\% higher odds of obesity at age $6 \mathrm{y}$. Four articles reported no association with BMI, BMIZ, odds of obesity or abdominal obesity $(26,32,33,43)$. Specifically, there were no significant associations between intake of SSBs (which included cordials, fruit drinks, and soft drinks but excluded juice) at 18mo and BMI-trajectory at 8 y (33) or from birth-11.5 y (32). Cantoral et al. (26) reported no significant association between SSB introduction (based on the sum of daily intake of soda, commercial fruit drinks, or flavored water with sugar exclusive of natural fruit juice) at or before $12 \mathrm{mo}$ vs. after $12 \mathrm{mo}$ of age and odds of obesity or abdominal obesity at age 8-14 y. Santorelli et al. (43) found no significant association between introduction of SSBs, including cola, lemonade, sweetened tea and pre-prepared 'baby' drinks, before 17 wk and BMIZ at 3 y of age.

\section{Juice drinks and $100 \%$ fruit juice.}

Six articles examined juice consumption primarily at or <1y of age (31-33, 38, 43, 45) (see Table 4). Juice was inconsistently described and juice consumption was defined differently across studies as follows: any vs. no intake of 'juice or other liquids' at ages 1, 3, 6, or 9 mo of age (38); fluid oz/d of orange juice or $100 \%$ fruit juice at $0,1-7,8-15$,or $>16$ oz/d (45); servings of "juice" at 0,1 , or $>1$ serving/2d (31); and intake of "non-milk beverages" including juice,cordials, fruit drinks, and soft drinks $(32,33)$. Two studies found significant positive associations between juice consumption and weight relative to length $(38,45)$ but both studies reported additional null results. Results from Kramer et al. show that intake of juice at 9 mo was associated with higher WLZ from 9-12 mo of age but not WAZ, LAZ, or HC at any age (38). Sonneville et al. (45) found that 8-15 oz/d of fruit juice at $1 \mathrm{y}$ vs. none was associated with increased BMIZ at $7.7 \mathrm{y}$, but lesser or greater amounts (1-7 oz, or $>16 \mathrm{oz} / \mathrm{d}$ ) were not associated with BMIZ at $7.7 \mathrm{y}$. In addition, the amount of fruit juice at $1 \mathrm{y}$ was not associated with BMIZ at $3.1 \mathrm{y}$ in fully-adjusted models. Gaffney et al. (31) found that infants who were given greater amounts of juice ( $>1$ serving of juice/2d vs. none) had significantly higher WAZ at 12 mo. However, there were no significant associations between lesser amounts ( $\leq 1$ serving of juice/2d vs. none) and WAZ at 12 mo. Garden et al. (33) and Garden et al. (32) found no association between intake of non-milk beverages which included juice, cordials, fruit drinks, and soft drinks at $18 \mathrm{mo}$ and BMI-trajectory at 8y (33) or from birth-11.5 y (32). Collectively, the findings from these observational studies suggest positive associations but are inconsistent given the variation in the definitions and amounts of juice intake and outcomes at different ages. 
Table 4. Studies that examined SSB, juice drinks and/or $100 \%$ juice and growth, size, and body composition

\begin{tabular}{|c|c|c|c|c|c|c|}
\hline $\begin{array}{l}\text { Reference }^{1} \text {, } \\
\text { country, } \\
\text { analytic N }\end{array}$ & Independent variable/exposure ${ }^{2}$ & $\begin{array}{l}\text { Results for } \\
\text { weight } \\
\text { status }\end{array}$ & $\begin{array}{l}\text { Results for } \\
\text { body } \\
\text { composition }\end{array}$ & $\begin{array}{l}\text { Results for } \\
\text { weight }\end{array}$ & $\begin{array}{l}\text { Results for } \\
\text { length/height }\end{array}$ & $\begin{array}{l}\text { Results for } \\
\text { head } \\
\text { circumference }\end{array}$ \\
\hline $\begin{array}{l}\text { Cantoral et } \\
\text { al., } 2016 \\
(26) \\
\text { Mexico } \\
\text { N: } 227\end{array}$ & $\begin{array}{l}\text { SSB introduction, } \leq 12 \text { vs }>12 \mathrm{mo} \text { : } \\
\text { sum daily intake of soda, } \\
\text { commercial fruit drinks, flavored } \\
\text { water with sugar; excludes natural } \\
\text { fruit/vegetable juice }\end{array}$ & $\begin{array}{l}\text { Obesity at 8- } \\
14 y, \text { NSA }\end{array}$ & $\begin{array}{l}\text { Abdominal } \\
\text { obesity at } 8-14 y \\
\text { NSA }\end{array}$ & & & \\
\hline \multirow{2}{*}{$\begin{array}{l}\text { Garden et } \\
\text { al., } 2011 \\
(33) \\
\text { Australia } \\
\text { N: } 362 ; 339 \\
\text { for WC }\end{array}$} & $\begin{array}{l}\text { SSB intake (g, \% energy) at age } \\
\text { 18mo; sweetened drinks including } \\
\text { cordials, fruit drinks, and soft } \\
\text { drinks }\end{array}$ & & $\begin{array}{l}\text { BMI at } 8 y, \text { NSA; } \\
\text { WC at } 8 y, N S A\end{array}$ & & & \\
\hline & $\begin{array}{l}\text { Juice+SSB intake ( } \mathrm{g}, \% \text { energy) at } \\
\text { age } 18 \mathrm{mo} \text {; non-milk beverages } \\
\text { including juice, cordials, fruit } \\
\text { drinks, and soft drinks }\end{array}$ & & $\begin{array}{l}\text { BMI at } 8 y, N S A ; \\
\text { WC at } 8 y, N S A\end{array}$ & & & \\
\hline \multirow[t]{4}{*}{$\begin{array}{l}\text { Garden et } \\
\text { al., } 2012 \\
(32) \\
\text { Australia } \\
\text { N: } 298\end{array}$} & $\begin{array}{l}\text { In boys, SSB intake ( } \mathrm{g}, \% \text { energy) } \\
\text { at age } 18 \mathrm{mo} \text {; sweetened drinks } \\
\text { including cordials, fruit drinks, and } \\
\text { soft drinks }\end{array}$ & & $\begin{array}{l}\text { BMI trajectory } \\
\text { birth-11.5y, NSA }\end{array}$ & & & \\
\hline & $\begin{array}{l}\text { In girls, SSB intake ( } \mathrm{g}, \% \text { energy) } \\
\text { at age } 18 \mathrm{mo} \text {; sweetened drinks } \\
\text { including cordials, fruit drinks, and } \\
\text { soft drinks }\end{array}$ & & $\begin{array}{l}\text { BMI trajectory } \\
\text { birth-11.5y, NSA }\end{array}$ & & & \\
\hline & $\begin{array}{l}\text { In boys, Juice+SSB intake (g, } \% \\
\text { energy) at age } 18 m o ; \text { non-milk } \\
\text { beverages including juice, cordials, } \\
\text { fruit drinks, and soft drinks }\end{array}$ & & $\begin{array}{l}\text { BMI trajectory } \\
\text { birth-11.5y, NSA }\end{array}$ & & & \\
\hline & $\begin{array}{l}\text { In girls, Juice+SSB intake (g, \% } \\
\text { energy) at age } 18 m 0 ; \text { non-milk }\end{array}$ & & $\begin{array}{l}\text { BMI trajectory } \\
\text { birth-11.5y, NSA }\end{array}$ & & & \\
\hline
\end{tabular}




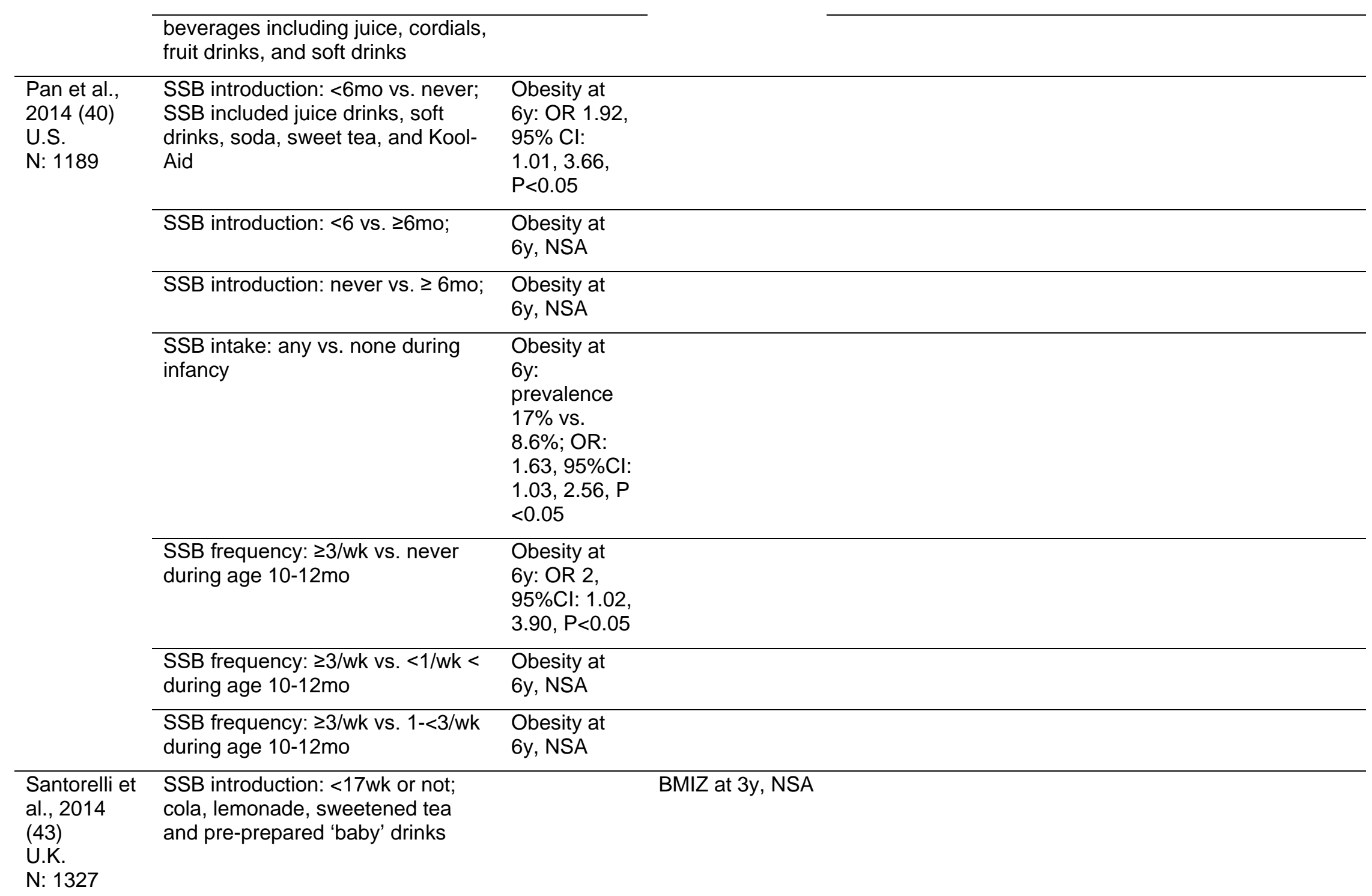




\begin{tabular}{|c|c|c|c|c|c|}
\hline \multirow{2}{*}{$\begin{array}{l}\text { Gaffney et } \\
\text { al., } 2012 \\
(31) \\
\text { U.S. } \\
\text { N: } 691\end{array}$} & $\begin{array}{l}\text { Juice intake intensity in the first } \\
\text { year: }>1 \text { vs. } 0 \text { serving/2d; type of } \\
\text { juice NR }\end{array}$ & & \multicolumn{3}{|l|}{$\begin{array}{l}\text { WAZ at } 12 \mathrm{mo} \\
\beta=0.25, P=0.002\end{array}$} \\
\hline & $\begin{array}{l}\text { Juice intake intensity in the first } \\
\text { year: } \leq 1 \text { vs. } 0 \text { serving/2d; type of } \\
\text { juice NR }\end{array}$ & & $\begin{array}{l}\text { WAZ at } 12 \mathrm{mo} \text {, } \\
\text { NSA }\end{array}$ & & \\
\hline $\begin{array}{l}\text { Kramer et } \\
\text { al., } 2004 \\
(38) \\
\text { Belarus } \\
\text { N: } 17,046\end{array}$ & $\begin{array}{l}\text { Juice/other liquids, any vs. none at } \\
1,3,6 \text {, or } 9 \mathrm{mo}\end{array}$ & $\begin{array}{l}\text { WLZ from age 9- } \\
12 \mathrm{mo}: \beta=0.061, \\
95 \% \mathrm{Cl}: 0.003, \\
0.119, \mathrm{P}=\mathrm{NR} ; \\
\text { from } 1-3,3-6, \\
\text { and } 6-9 \mathrm{mo}, \mathrm{NSA}\end{array}$ & $\begin{array}{l}\text { WAZ from age } \\
1-3,3-6,6-9 \text { or } \\
9-12 \mathrm{mo}, \mathrm{NSA}\end{array}$ & $\begin{array}{l}\text { LAZ from age } 1- \\
3,3-6,6-9 \text { or } 9- \\
12 \mathrm{mo}, \mathrm{NSA}\end{array}$ & $\begin{array}{l}\text { HC from age } 1- \\
3,3-6,6-9 \text { or } 9- \\
12 \mathrm{mo}, \mathrm{NSA}\end{array}$ \\
\hline $\begin{array}{l}\text { Sonneville } \\
\text { et al., } 2015 \\
\text { (45) } \\
\text { U.S. } \\
\text { N: } 1163\end{array}$ & $\begin{array}{l}\text { Fruit juice (orange juice or } 100 \% \\
\text { fruit juice) intake at age } 1 \mathrm{y}: 0,1-7 \text {, } \\
8-15,16-31 \text {, or }>320 z\end{array}$ & $\begin{array}{l}\text { BMIZ at 7.7y: } 1- \\
\text { 7oz: } \beta=0.07, \\
95 \% \mathrm{Cl}:-0.06, \\
0.21 ; 8-150 z: \\
\beta=0.23,95 \% \mathrm{Cl} \text { : } \\
0.005,0.40 ; \\
>160 z: \beta=0.27 \\
95 \% \mathrm{Cl}:-0.05, \\
0.59 \text { vs. 0oz, } \\
\text { P=0.05; BMIZ at } \\
\text { 3.1y, NSA }\end{array}$ & & & \\
\hline
\end{tabular}

1. All studies, except those noted as RCT or non-RCT, followed a prospective cohort design

2. The independent variable/exposure of interest included types and/or amounts of CFB, which encompassed dietary patterns during the complementary feeding period and timing of specific CFB; this section of studies examined sugar-sweetened beverage, juice drinks, and/or $100 \%$ juice.

3. Outcomes were organized for practicality into columns: weight status, body composition, weight, length or height, and head circumference. Results described in the respective columns are based on outcome similarity and in accordance with the analytical framework as follows: Weight status included risk/incidence/prevalence/frequency of malnutrition, healthy weight, overweight, or obesity; Body composition included measures, indices, and proxies of overall adiposity such as lean mass, fat mass (FM), \% body fat, weight-to-height ratios such as BMI, BMIZ, WLZ, central adiposity or waist circumference, and arm or thigh circumferences; Weight included weight-specific measures such as weight-for-age z-score (WAZ), Length or Height included length-specific measures such as length-for-age Z-score (LAZ); Head circumference included head circumference 
Abbreviations: BF, breast-fed; BMIZ, BMI z-score; CFB, complementary food/beverage; HC, head circumference; LAZ, length for age z-score; NR, not reported; NSA, no significant association; NSGD, no significant group differences; RCT, randomized controlled trial; SSB, sugarsweetened beverage; WAZ, weight for age z-score; WLZ, weight for length z-score 


\section{Other CFB}

Sixteen articles examined distinct types, amounts, groups, or introductions of other CFB $(7,8,19,21,22,27,29,30,32,33,36-38,43,44,49)$ using different assessment methods and are described in more detail in Table 5 . These other CFB were examined during intervals or at specific ages, primarily between 4 and $12 \mathrm{mo}$, relative to various outcomes ranging in age from $4 \mathrm{mo}$ up to $42 \mathrm{y}$. Although a few significant associations were identified (see Table 5), there was insufficient evidence, inconsistency, and substantial methodological limitations across these studies that prevented conclusions from being drawn.

Types of Other CFB. Lind et al. (7) reported no differences between groups randomized to receive regular-phytate vs. reduced-phytate milk-cereal drink and porridge from 6-12 mo in WAZ, LAZ, MUAC, or HC at 6, 12, or 18 mo of age (7). Liu et al. (8) found no differences between BF infants and toddlers receiving a fortified (Fe, Zn, vitamin A, calcium, folic acid) or non-fortified biscuit daily for $3 \mathrm{mo}$ in weight or length at ages 9-16 mo of age. de Silva et al. (19) reported that infants who were assigned to receive 'home-based CFB' (i.e., a CFB made with common foods including red rice, red lentils, and vegetable oil) from 4-12 mo had significantly greater weight gain from 4-12 mo than those receiving mom's choice of CFB, but found no differences in length gain 4-12 mo of age. Virtanen et al. (16) found no significant differences between infants, who were randomly assigned to receive cow's milk that was either standard-fat, low-fat, or iron-fortified with either $50 \%$ vegetable fat and vitamin C, or $100 \%$ vegetable fat, with respect to weight at $18 \mathrm{mo}$, or weight change from 12-18 mo of age. Almquist-Tangen et al. (21) found that MCD at 6 mo of age, but not porridge or semi-solid foods, was significantly associated with high BMI (>1SD) at $12 \mathrm{mo}$ and $18 \mathrm{mo}$ of age. However, several potential key confounders were not adjusted for in analyses (SES, race/ethnicity, feeding practices) and no other outcomes were examined that could inform the results. For instance, it is unknown whether high BMI was driven by gains in FM or weight or decreases in length percentiles. Carruth et al. (27) reported that consumption of meat, mixed food, and/or table food by age 8 mo was associated with a smaller weight change from age 2-8 mo, although this did not remain significant after adjusting for length slope. lanotti et al. (36) reported no differences between infants consuming animal source foods (meat, fish, egg, or milk) or other CFB (cereal, mixed or blended foods, stews, bread or other cereal products) from 612 mo of age with respect to MUAC, weight, length, or $\mathrm{HC}$ from 1-12 mo of age. Kalies et al. (37) reported a significantly lower risk of elevated weight gain (difference between weight at birth and at 24 mo of age) among infants consuming 'ready-made' vs. 'self-made' foods and 'mixed CFB' vs. 'self-made' foods. Santorelli et al. (43) found no significant association between intake of non-sweetened solid foods (e.g., baby rice, pureed vegetables, fruits or rice, and lentils/dhal) or sweetened foods (e.g. egg custard, rice pudding, sweetened rusks, biscuits and cake) and BMIZ at 3 y of age. Wosje et al. (48) found no significant differences between those consuming whole-milk vs. $2 \%$ fat milk with respect to (absolute or change in) weight, length, and body fat from 12-24 mo of age. 
Amount of Other CFB. Two articles from one observational study mentioned previously $(32,33)$ examined intake in quintiles by weight and \% total energy of additional CFB at 18 mo of age including dairy foods (milk, yogurt, cheese, ice cream, custard), milk (skim, whole and evaporated), fruits, vegetables, total extra foods (e.g., savory sauces, fats, and oils), fried potatoes, salty snacks (e.g., cheese snacks, corn chips), confectionary (e.g., chocolate, jellies), cereal foods, including bread, pasta, rice, and breakfast cereals and cereal-based products (e.g., cookies, cakes). In terms of significant findings, negative associations were identified between the amount of cereal-based products and dairy foods consumed and BMI at age $8 \mathrm{y}$. In addition, positive associations were identified between the amount of fruit intake and WC at $8 y$ of age. Although they did not reach significance, there were trends suggesting that greater intake of vegetables was associated with higher $\mathrm{BMI}$ at $8 \mathrm{y}$ whereas greater intake of confectionary foods was associated with lower $\mathrm{BMI}$ at $8 \mathrm{y}$. The amount consumed of other remaining foods (e.g., milk, cerealfoods, fried potatoes; salty snacks) were not significantly associated with BMI in either analysis $(32,33)$.

Other CFB introduction. Three articles from one observational study (Generation R) examined the age of introduction to fruit or vegetable snacks $(22,29,30)$. Two articles found no significant associations between fruit or vegetable snack introduction and body composition $(22,29)$. Durmus et al. (30) found that fruit or vegetable snack introduction at $4-5$ mo relative to $>5$ mo was significantly associated with greater thickness (total FM) at age 24 mo. Durmus et al. (30) found no other associations between introduction at $<4,4-5$, or $>5 \mathrm{mo}$ and other outcomes including total, peripheral, or central FM at 24 mo or odds of overweight or obesity at 6 y of age.

Kramer et al. (38) found that intake of "other solids" (not described) at age 9 mo was associated with significantly lower LAZ from 9-12 mo of age but found no association with WLZ, WAZ, or HC at any age interval. Carruth et al. (27) reported that age of vegetable introduction was associated with lower weight change from age 2-8 mo in the final predictive model, although this did not remain significant after adjusting for length slope. Schack-Nielsen et al. (44) reported that later introduction of vegetables and firm food were significantly associated with decreased risk of overweight at $42 \mathrm{y}$ but not with BMI at 20-34 y. Later introduction of vegetables was associated with decreased BMI at 20-34 y and $42 \mathrm{y}$. Associations between egg introduction (continuous) and overweight at ages 20-34 y or 42 y were not significant. Introduction of firm food (bread and biscuits mixed with milk) was negatively associated with BMIZ at age $1 \mathrm{y}, 10 \mathrm{y}$ and $11 \mathrm{y}$ but this did not persist at $42 \mathrm{y}$. Later introduction of spoon-feeding (continuous) was not associated with risk of overweight at $42 \mathrm{y}$ but was significantly associated with lower $\mathrm{BMI}$ at $42 \mathrm{y}$ and smaller WC at $42 \mathrm{y}$. When examined categorically, there was a non-significant trend for later introduction ( $\geq 4 \mathrm{vs}$. $<4 \mathrm{mo}$ ) of spoon-feeding to be associated with decreased risk of overweight at $42 \mathrm{y}$. Schack-Nielsen et al. (44) also found no significant associations between number of food items from the CFB groups at ages $3,4,5$, or 6 mo and risk of overweight at $42 \mathrm{y}$. Zheng et al. (49) reported that introduction to fish liver oil <3 vs. at $4-6$ mo was significantly 
associated with increased risk of overweight at $4-5 \mathrm{y}$, but not obesity at 4-5 y. There were no significant associations between introduction to other CFB examined in that study (e.g., egg yolk, liver paste, tofu) and risk of overweight or obesity at 4-5 y of age (49). 
Table 5. Studies that examined other CFB and growth, size, and body composition

\begin{tabular}{|c|c|c|c|c|c|c|}
\hline $\begin{array}{l}\text { Reference }^{1}, \\
\text { country, } \\
\text { analytic } \mathbf{N}\end{array}$ & Independent variable/exposure ${ }^{2}$ & $\begin{array}{l}\text { Results for } \\
\text { weight status }\end{array}$ & $\begin{array}{l}\text { Results for } \\
\text { body } \\
\text { composition }\end{array}$ & $\begin{array}{l}\text { Results for } \\
\text { weight }\end{array}$ & $\begin{array}{l}\text { Results for } \\
\text { length/height }\end{array}$ & $\begin{array}{l}\text { Results for } \\
\text { circumference }\end{array}$ \\
\hline \multirow{3}{*}{$\begin{array}{l}\text { Almquist- } \\
\text { Tangen et } \\
\text { al., 2013 } \\
\text { (Almquist- } \\
\text { Tangen, } \\
\text { 2013) } \\
\text { Sweden } \\
\text { N: 2,404 } \\
12 \mathrm{mo} \text {; } \\
2,241 \text { 18mo }\end{array}$} & Milk cereal drink, $\mathrm{Y} / \mathrm{N}$ at age $6 \mathrm{mo}$ & $\begin{array}{l}\text { High BMI: at } \\
\text { 12mo OR=1.66, } \\
95 \% \mathrm{Cl}: 1.07- \\
2.57, \mathrm{P}=0.02 ; \text { at } \\
\text { 18mo OR=1.58 } \\
95 \% \mathrm{Cl}: 1.04- \\
2.39, \mathrm{P}=0.03\end{array}$ & & & & \\
\hline & Porridge intake, $\mathrm{Y} / \mathrm{N}$ at age $6 \mathrm{mo}$ & $\begin{array}{l}\text { High BMI at } 12 \\
\text { or } 18 \mathrm{mo}, \mathrm{NSA}\end{array}$ & & & & \\
\hline & Semi-solids intake, $\mathrm{Y} / \mathrm{N}$ at age $6 \mathrm{mo}$ & $\begin{array}{l}\text { High BMI at } 12 \\
\text { or } 18 \mathrm{mo}, \mathrm{NSA}\end{array}$ & & & & \\
\hline $\begin{array}{l}\text { Ay et al., } \\
2008(22) \\
\text { Netherlands } \\
\text { N: } 1012\end{array}$ & $\begin{array}{l}\text { Fruit snack introduction: }<5 \text { or } \\
>5 \mathrm{mo}\end{array}$ & & $\begin{array}{l}\text { Skinfold } \\
\text { thickness at } \\
24 \mathrm{mo}, \mathrm{NSA}\end{array}$ & & & \\
\hline \multirow[t]{2}{*}{$\begin{array}{l}\text { Carruth et } \\
\text { al., } 2000 \\
(27) \\
\text { U.S. } \\
\text { N: } 94\end{array}$} & $\begin{array}{l}\text { Food cluster present by age } 8 \mathrm{mo} \text { : } \\
\text { any meat, mixed foods or table } \\
\text { foods }\end{array}$ & & & $\begin{array}{l}\text { Weight } \\
\text { change 2- } \\
8 \mathrm{mo}, \beta=- \\
0.1755, \\
P=0.0324 \text { but } \\
\text { final model, } \\
\text { NSA }\end{array}$ & & \\
\hline & Vegetable introduction, continuous & & & $\begin{array}{l}\text { Weight } \\
\text { change } 2- \\
8 \mathrm{mo}, \beta=- \\
0.0567, \\
P=0.0457 \text { but } \\
\text { final model, }\end{array}$ & & \\
\hline
\end{tabular}




\begin{tabular}{|c|c|c|c|c|c|}
\hline $\begin{array}{l}\text { de Silva et } \\
\text { al., } 2007 \\
(19) \\
\text { Non-RCT; } \\
\text { Sri Lanka } \\
\text { N: } 152\end{array}$ & $\begin{array}{l}\text { Intervention: home-based CFB + } \\
\text { recipes + mechanical blender from } \\
\text { age } 4-12 \text { mo vs. Control: CFB of } \\
\text { mothers' choice from age } 4-12 \text { mo }\end{array}$ & & & $\begin{array}{l}\text { Weight gain } \\
4-12 \mathrm{mo}: \\
2.43 \text {, } \\
\mathrm{SD}=0.72 \mathrm{~kg} \\
\text { vs. } 2.02 ; \\
\mathrm{SD}=0.62 \mathrm{~kg} \text {, } \\
\mathrm{P}=0.0002\end{array}$ & $\begin{array}{l}\text { Length gain 4- } \\
12 \mathrm{mo}, \mathrm{NSGD}\end{array}$ \\
\hline \multirow[t]{2}{*}{$\begin{array}{l}\text { Durmus et } \\
\text { al., } 2012 \\
\text { (30) } \\
\text { Netherlands } \\
\text { N: } 779\end{array}$} & $\begin{array}{l}\text { Fruit or vegetable snack } \\
\text { introduction: } 4-5 \text { vs. }>5 \mathrm{mo}\end{array}$ & & $\begin{array}{l}\text { Total, peripheral } \\
\text { or central FM at } \\
6 \mathrm{mo}, \mathrm{NSA} \text {; Total } \\
\text { FM at age } 24 \mathrm{mo} \text {, } \\
\beta=1.46,95 \% \mathrm{Cl}: \\
0.05,2.88, \\
\mathrm{P}<0.05 ; \\
\text { Peripheral or } \\
\text { central FM at } \\
24 \mathrm{mo}, \mathrm{NSA}\end{array}$ & & \\
\hline & $\begin{array}{l}\text { Fruit or vegetable snack } \\
\text { introduction: }<4 \text { vs. }>5 \mathrm{mo}\end{array}$ & & $\begin{array}{l}\text { Total, peripheral } \\
\text { or central FM at } \\
6 \text { or } 24 \mathrm{mo}, \mathrm{NSA}\end{array}$ & & \\
\hline $\begin{array}{l}\text { Durmus et } \\
\text { al., } 2014 \\
\text { (29) } \\
\text { Netherlands } \\
\text { N: } 5063\end{array}$ & $\begin{array}{l}\text { Fruit or vegetable snack } \\
\text { introduction: }<4,4-4.9, \geq 5 \mathrm{mo}\end{array}$ & $\begin{array}{l}\text { Overweight or } \\
\text { obesity at 6y, } \\
\text { NSA }\end{array}$ & $\begin{array}{l}\text { Total FM, } \\
\text { android-gynoid } \\
\text { fat ratio, } \\
\text { abdominal fat, or } \\
\text { BMl at 6y }\end{array}$ & & \\
\hline \multirow[t]{2}{*}{$\begin{array}{l}\text { Garden et } \\
\text { al., } 2011 \\
\text { (33) } \\
\text { Australia } \\
\text { N: } 362 \\
\text { (WC: 339) }\end{array}$} & $\begin{array}{l}\text { Dairy products: combined milk and } \\
\text { milk product yogurt, cheese, ice } \\
\text { cream, custard intake ( } \mathrm{g}, \% \text { total } \\
\text { energy) at age } 18 \mathrm{mo}\end{array}$ & & $\begin{array}{l}\text { BMI at } 8 y, \% \\
\text { energy, } \beta=-0.21 \text {; } \\
95 \% \mathrm{Cl}:-0.41,- \\
0.01 ; P=0.04 ; \mathrm{g} \text {, } \\
\text { NSA; WC at } 8 \mathrm{y} \text {, } \\
\text { NSA }\end{array}$ & & \\
\hline & $\begin{array}{l}\text { Milk: skim, whole, and evaporated } \\
\text { intake (g, \% total energy) at age } \\
18 \mathrm{mo}\end{array}$ & & $\begin{array}{l}\text { BMI at } 8 y, N S A ; \\
\text { WC at } 8 y, N S A\end{array}$ & & \\
\hline
\end{tabular}


Fruit intake ( $g, \%$ total energy) at age $18 \mathrm{mo}$
$\mathrm{BMI}$ at $8 \mathrm{y}, \mathrm{NSA}$;

WC at $8 \mathrm{y}, \mathrm{g}$

$\beta=0.63 ; 95 \% \mathrm{Cl}$ :

$0.05,1.2$,

$\mathrm{P}=0.03 ; \%$ total

energy $\beta=0.56$,

$95 \% \mathrm{Cl}: 0.00$,

$1.1, \mathrm{P}=0.05$

Vegetables intake $(\mathrm{g}, \%$ total energy) at age $18 \mathrm{mo}$

BMI at $8 y, g$

$\mathrm{B}=0.20 ; 95 \%$

Cl:0.00, 0.40

Trend $\mathrm{P}=0.05$,

NSA; \% energy,

NSA; WC at $8 y$,

NSA

Cereal-foods: bread, pasta, rice

breakfast cereals, etc. intake (g, \%

BMI at 8y, NSA;

WC at $8 y, N S A$

total energy) at age $18 \mathrm{mo}$

\begin{tabular}{ll}
\hline Total Extra foods: savory sauces, & BMI at 8y, NSA; \\
fats, and oils, etc. intake ( $\mathrm{g}, \%$ total & WC at 8y, NSA
\end{tabular}

energy) at age $18 \mathrm{mo}$

\begin{tabular}{|c|c|}
\hline $\begin{array}{l}\text { Fried Potatoes intake ( } \mathrm{g}, \% \text { total } \\
\text { energy) at age } 18 \mathrm{mo}\end{array}$ & $\begin{array}{l}\text { BMI at 8y, NSA; } \\
\text { WC at 8y, NSA }\end{array}$ \\
\hline $\begin{array}{l}\text { Salty snacks: potato crisps, cheese } \\
\text { snacks, corn chips intake ( } \mathrm{g}, \% \\
\text { total energy) at age } 18 \mathrm{mo}\end{array}$ & $\begin{array}{l}\text { BMI at 8y, NSA; } \\
\text { WC at } 8 y, N S A\end{array}$ \\
\hline $\begin{array}{l}\text { Confectionary Foods: chocolate, } \\
\text { jellies, energy bars intake ( } \mathrm{g}, \% \\
\text { total energy) at age } 18 \mathrm{mo}\end{array}$ & $\begin{array}{l}\text { BMI at } 8 y, \beta=- \\
0.25,95 \% \mathrm{Cl}:- \\
0.49,0.00, \text { Trend } \\
P=0.05, N S A ; \\
\text { WC at } 8 y, N S A\end{array}$ \\
\hline $\begin{array}{l}\text { Cereal-based products: cookies, } \\
\text { cakes, pies, buns, etc. intake (g, } \% \\
\text { total energy) at age } 18 \mathrm{mo}\end{array}$ & $\begin{array}{l}\text { BMI at } 8 y, g: \beta=- \\
0.23,95 \% \mathrm{Cl}:- \\
0.44,-0.22 \\
P=0.03 ; \%\end{array}$ \\
\hline
\end{tabular}


Energy, $\beta=-0.27$;

$95 \%$ Cl:-0.47, -

$0.07, P=0.01$;

$W C$ at $8 \mathrm{y} \mathrm{g} \beta=-$

$0.61 ; 95 \% \mathrm{Cl}:-$

1.17, -0.05 ,

$\mathrm{P}=0.03 ; \%$

energy, $\beta=-0.76$,

$95 \% \mathrm{Cl}:-1.29$, -

$0.23, \mathrm{P}=0.01$

\begin{tabular}{|c|c|c|}
\hline \multirow[t]{6}{*}{$\begin{array}{l}\text { Garden et } \\
\text { al., } 2012 \\
(32) \\
\text { Australia } \\
\text { N: } 298\end{array}$} & $\begin{array}{l}\text { Dairy products: combined milk and } \\
\text { milk product yogurt, cheese, ice } \\
\text { cream, custard intake ( } \mathrm{g}, \% \text { total } \\
\text { energy) at age } 18 \mathrm{mo}\end{array}$ & $\begin{array}{l}\text { BMI trajectory } \\
\text { birth-11.5y in } \\
\text { boys or girls, } \\
\text { NSA }\end{array}$ \\
\hline & $\begin{array}{l}\text { Milk: skim, whole, and evaporated } \\
\text { intake ( } \mathrm{g}, \% \text { total energy) at age } \\
\text { 18mo }\end{array}$ & $\begin{array}{l}\text { BMI trajectory } \\
\text { birth-11.5y in } \\
\text { boys or girls, } \\
\text { NSA }\end{array}$ \\
\hline & $\begin{array}{l}\text { Fruit intake ( } \mathrm{g}, \% \text { total energy) at } \\
\text { age } 18 \mathrm{mo}\end{array}$ & $\begin{array}{l}\text { BMI trajectory } \\
\text { birth-11.5y in } \\
\text { boys or girls, } \\
\text { NSA }\end{array}$ \\
\hline & $\begin{array}{l}\text { Vegetables intake ( } \mathrm{g}, \% \text { total } \\
\text { energy) at age } 18 \mathrm{mo}\end{array}$ & $\begin{array}{l}\text { BMI trajectory } \\
\text { birth-11.5y in } \\
\text { boys or girls, } \\
\text { NSA }\end{array}$ \\
\hline & $\begin{array}{l}\text { Cereal-foods: bread, pasta, rice, } \\
\text { breakfast cereals, etc. intake (g, \% } \\
\text { total energy) at age } 18 \mathrm{mo}\end{array}$ & $\begin{array}{l}\text { BMI trajectory } \\
\text { birth-11.5y in } \\
\text { boys or girls, } \\
\text { NSA }\end{array}$ \\
\hline & $\begin{array}{l}\text { Total Extra foods: savory sauces, } \\
\text { fats, and oils, etc. intake ( } \mathrm{g}, \% \text { total } \\
\text { energy) at age } 18 \mathrm{mo}\end{array}$ & $\begin{array}{l}\text { BMI trajectory } \\
\text { birth-11.5y in } \\
\text { boys or girls, } \\
\text { NSA }\end{array}$ \\
\hline
\end{tabular}


Fried Potatoes intake ( $\mathrm{g}, \%$ total energy) at age $18 \mathrm{mo}$
BMI trajectory

birth-11.5y in

boys or girls,

NSA

Salty snacks: potato crisps, cheese

snacks, corn chips intake ( $\mathrm{g}, \%$

total energy) at age $18 \mathrm{mo}$

BMI trajectory

birth-11.5y in

boys or girls,

NSA

Confectionary Foods: chocolate,

jellies, energy bars intake $(\mathrm{g}, \%$

total energy) at age $18 \mathrm{mo}$

BMI trajectory

birth-11.5y in

boys or girls,

NSA

Cereal-based products: cookies,

cakes, pies, buns, etc. intake ( $\mathrm{g}, \%$

total energy) at age $18 \mathrm{mo}$

BMI trajectory

birth-11.5y in

boys or girls,

NSA

\begin{tabular}{|c|c|c|c|c|c|}
\hline $\begin{array}{l}\text { lannotti et } \\
\text { al., } 2009 \\
(36) \\
\text { Peru } \\
\text { N: } 232\end{array}$ & $\begin{array}{l}\text { CFB vs. CFB from animal sources } \\
\text { (i.e., meat, fish, egg, or milk) at } \\
\text { age } 6-12 \text { mo }\end{array}$ & $\begin{array}{l}\text { Skinfolds from 6- } \\
12 \text { mo or MUAC } \\
\text { from 1-12mo, } \\
\text { NSA }\end{array}$ & $\begin{array}{l}\text { Weight 1- } \\
\text { 12mo, NSA }\end{array}$ & $\begin{array}{l}\text { Length 1-12mo, } \\
\text { NSA }\end{array}$ & $\begin{array}{l}\text { HC 1-12mo, } \\
\text { NSA }\end{array}$ \\
\hline \multirow{2}{*}{$\begin{array}{l}\text { Kalies et al., } \\
2005(37) \\
\text { Germany } \\
\text { N: } 2,337\end{array}$} & Mixed CFB vs. Self-made CFB & & $\begin{array}{l}\text { Weight gain } \\
\text { at } 24 \mathrm{mo}, \\
\text { NSA }\end{array}$ & & \\
\hline & $\begin{array}{l}\text { Ready-made CFB vs. Self-made } \\
\text { CFB }\end{array}$ & & $\begin{array}{l}\text { Weight gain } \\
\text { at } 24 \mathrm{mo} \text { : OR } \\
0.56,95 \% \mathrm{Cl} \text { : } \\
0.39,0.81 \text {, } \\
\text { P=NR }\end{array}$ & & \\
\hline $\begin{array}{l}\text { Kramer et } \\
\text { al., } 2004 \\
(38) \\
\text { Belarus } \\
\mathrm{N}: 17,046\end{array}$ & $\begin{array}{l}\text { Other solids intake, any vs. none at } \\
\text { ages } 1,3,6 \text {, or } 9 \mathrm{mo}\end{array}$ & $\begin{array}{l}\text { WLZ 1-3, 3-6, 6- } \\
9, \text { and } 9-12 \text { mo of } \\
\text { age, NSA }\end{array}$ & $\begin{array}{l}\text { WAZ from 1- } \\
3,3-6,6-9,9- \\
12 \text { mo of age, } \\
\text { NSA }\end{array}$ & $\begin{array}{l}\text { LAZ from age 9- } \\
12 \mathrm{mo}: \beta=-0.082 \text {, } \\
95 \% \mathrm{Cl}:-0.156 \text {, } \\
-0.008, P=\mathrm{NR} \\
1-3,3-6,6-9 \mathrm{mo}\end{array}$ & $\begin{array}{l}\text { HC from } 1-3,3- \\
6,6-9, \text { or } 9- \\
12 \text { mo of age, } \\
\text { NSA }\end{array}$ \\
\hline
\end{tabular}




\begin{tabular}{|c|c|c|c|c|c|c|}
\hline $\begin{array}{l}\text { Liu et al., } \\
1993(8) \\
\text { RCT; China } \\
\text { N: } 164\end{array}$ & $\begin{array}{l}\text { Fortified Rusk: fortified (Fe, Zn, vit. } \\
\text { A, calcium, folic acid) biscuit, } 1 / \mathrm{d} \\
\text { for } 3 \mathrm{mo} \text {, ages } 6-16 \mathrm{mo} \text { vs. } \\
\text { Unfortified Rusk: unfortified biscuit } \\
1 / \mathrm{d} \text { for } 3 \mathrm{mo} \text {, ages } 6-16 \mathrm{mo}\end{array}$ & & & $\begin{array}{l}\text { Weight or } \\
\text { increase in } \\
\text { weight at } \\
\text { ages } \sim 9- \\
\text { 16mo, NSGD }\end{array}$ & $\begin{array}{l}\text { Length or } \\
\text { increase in } \\
\text { length, at ages } \\
\sim 9-16 \mathrm{mo}, \mathrm{NSGD}\end{array}$ & \\
\hline \multirow[t]{3}{*}{$\begin{array}{l}\text { Lind et al., } \\
2004 \text { (7) } \\
\text { RCT; } \\
\text { Sweden } \\
\text { N: } 263\end{array}$} & $\begin{array}{l}\text { Regular-phytate group: commercial } \\
\text { MCD from oat and wheat flours } \\
\text { mixed with milk powder and Fe- } \\
\text { fortifed, at ages } 6 \text { to } 12 \mathrm{mo}\end{array}$ & & & $\begin{array}{l}\text { WAZ at } 6, \\
12,18 \text { mo, } \\
\text { NSGD }\end{array}$ & $\begin{array}{l}\text { LAZ at } 6,12,18 \\
\text { mo, NSGD }\end{array}$ & $\begin{array}{l}\mathrm{HC} \text { at } 6,12,18 \\
\text { mo, NSGD; } \\
\text { MUAC at } 6,12, \\
18 \text { mo, NSGD }\end{array}$ \\
\hline & $\begin{array}{l}\text { Reduced-phytate group: phytate- } \\
\text { reduced MCD from white-wheat } \\
\text { flour and porridge from age 6-12 } \\
\text { mo }\end{array}$ & & & & & \\
\hline & $\begin{array}{l}\text { Infant formula group: milk-based } \\
\text { infant formula and porridge }\end{array}$ & & & & & \\
\hline \multirow[t]{2}{*}{$\begin{array}{l}\text { Santorelli et } \\
\text { al., } 2014 \\
\text { (43) } \\
\text { U.K. } \\
\text { N: } 1327\end{array}$} & $\begin{array}{l}\text { Non-sweetened solid foods } \\
\text { introduction: baby rice, pureed } \\
\text { vegetables, fruits or rice, and } \\
\text { lentils/dhal }\end{array}$ & & BMIZ at $3 y$, NSA & & & \\
\hline & $\begin{array}{l}\text { Sweetened foods introduction: egg } \\
\text { custard, rice pudding, sweetened } \\
\text { rusks, biscuits and cake (plus non- } \\
\text { sweetened foods when given } \\
\text { together) }\end{array}$ & & BMIZ at $3 y$, NSA & & & \\
\hline $\begin{array}{l}\text { Schack- } \\
\text { Nielsen et } \\
\text { al., } 2010 \\
\text { (44) } \\
\text { Denmark } \\
\text { N: } 5068\end{array}$ & $\begin{array}{l}\text { Spoon-feeding introduction, } \\
\text { continuous }\end{array}$ & $\begin{array}{l}\text { At 42y, } \\
\text { overweight, } \\
\text { NSA; obesity, } \\
\text { NSA }\end{array}$ & $\begin{array}{l}\text { BMI ages: } 1-34 y, \\
\text { NSA; } 42 \mathrm{y}, \beta=- \\
0.046,95 \% \mathrm{Cl}:- \\
0.86,-0.006, \\
\mathrm{P}=0.03 ; \mathrm{WC} \text { at } \\
42 \mathrm{y},-0.25 \\
\mathrm{~cm} / \mathrm{mo}, 95 \% \mathrm{Cl}-\end{array}$ & & & \\
\hline
\end{tabular}




\section{$0.49,-0.01$}

\begin{tabular}{|c|c|c|}
\hline $\begin{array}{l}\text { Spoon-feeding introduction, } \geq 4 \text { vs. } \\
<4 \mathrm{mo}\end{array}$ & $\begin{array}{l}\text { Lower risk of } \\
\text { overweight at } \\
42 y, P=0.053\end{array}$ & \\
\hline Vegetable introduction, continuous & $\begin{array}{l}\text { At } 42 \mathrm{y}, \\
\text { overweight, OR } \\
0.90,95 \% \mathrm{Cl} \text { : } \\
0.81,0.98, \\
\mathrm{P}=0.014 ; \\
\text { obesity, NSA }\end{array}$ & $\begin{array}{l}\text { BMIZ at ages: } \\
20-34 \mathrm{y}, \beta=- \\
0.072 ; 95 \% \mathrm{Cl}- \\
0.133,-0.010 ; \\
42 \mathrm{y}, \beta=-0.064 ; \\
95 \% \mathrm{Cl}:-0.101,- \\
0.027\end{array}$ \\
\hline $\begin{array}{l}\text { Vegetable introduction, } \geq 4 \text { vs. } \\
<4 \mathrm{mo}\end{array}$ & $\begin{array}{l}\text { Lower risk of } \\
\text { overweight at } \\
42 y, P=0.046\end{array}$ & \\
\hline Egg introduction, continuous & $\begin{array}{l}\text { At 42y, } \\
\text { overweight, } \\
\text { NSA; obesity, } \\
\text { NSA }\end{array}$ & $\begin{array}{l}\text { BMI at 20-34y or } \\
42 y, N S A\end{array}$ \\
\hline Egg introduction, $\geq 4$ vs. $<4 \mathrm{mo}$ & $\begin{array}{l}\text { Overweight at } \\
42 y, N S A\end{array}$ & \\
\hline Firm food introduction, continuous & $\begin{array}{l}\text { At } 42 \mathrm{y}, \\
\text { overweight, OR } \\
0.92,95 \% \mathrm{Cl} \text { : } \\
0.86,0.98, \\
\mathrm{P}=0.012 ; \\
\text { obesity, NSA }\end{array}$ & $\begin{array}{l}\text { BMIZ at ages: } \\
1 \mathrm{y}, \beta=-0.053, \\
95 \% \mathrm{Cl}:-0.082,- \\
0.024 ; 10 \mathrm{y}, \beta=- \\
0.054,95 \% \mathrm{Cl}:- \\
0.096,-0.012 ; \\
11 \mathrm{y}, \beta=-0.057, \\
95 \% \mathrm{Cl}:-0.101,- \\
0.0103 ; 20-34 \mathrm{y} \\
\text { or } 42 \mathrm{y}, \mathrm{NSA}\end{array}$ \\
\hline $\begin{array}{l}\text { Firm food introduction, } \geq 4 \text { vs. } \\
<4 \mathrm{mo}\end{array}$ & $\begin{array}{l}\text { Overweight at } \\
42 y, N S A\end{array}$ & \\
\hline
\end{tabular}




\begin{tabular}{|c|c|c|c|c|c|}
\hline $\begin{array}{l}\text { Virtanen et } \\
\text { al., } 2001 \\
(16) \\
\text { RCT; } \\
\text { Sweden } \\
\text { N: } 36\end{array}$ & $\begin{array}{l}\text { Cow's milk: Low-fat or standard- } \\
\text { fat, ad libitum at age } 12-18 \mathrm{mo} \\
\text { vs. Fe-fortified cow's milk: ferrous } \\
\text { gluconate-fortified with } 50 \% \\
\text { vegetable fat or ferrous lactate- } \\
\text { fortified with } 100 \% \text { vegetable fat, } \\
\text { ad libitum at age } 12-18 \mathrm{mo}\end{array}$ & & & $\begin{array}{l}\text { Weight at } \\
\text { 18mo,NSGD; } \\
\text { weight } \\
\text { change from } \\
\text { 12-18mo, } \\
\text { NSGD }\end{array}$ & \\
\hline $\begin{array}{l}\text { Wosje et } \\
\text { al., } 2001 \\
(48) \\
\text { U.S. } \\
\text { N: } 51\end{array}$ & $\begin{array}{l}2 \% \text { cow's milk vs. whole at age } \\
12 \mathrm{mo}\end{array}$ & & $\begin{array}{l}\% \text { body fat, } \% \\
\text { body fat } z \text { score, } \\
\% \text { body fat gain, } \\
\text { or change in } \% \\
\text { body fat } z-\text { score } \\
\text { from } 12-24 m o, \\
\text { NSA }\end{array}$ & $\begin{array}{l}\text { Weight, } \\
\text { weight z- } \\
\text { score, weight } \\
\text { gain, or } \\
\text { change in } \\
\text { weight z- } \\
\text { score from } \\
\text { 12-24mo, } \\
\text { NSA }\end{array}$ & $\begin{array}{l}\text { Length, length z } \\
\text { score, length } \\
\text { gain, or change } \\
\text { in length z score } \\
\text { from } 12-24 \mathrm{mo} \text {, } \\
\text { NSA }\end{array}$ \\
\hline \multirow[t]{4}{*}{$\begin{array}{l}\text { Zheng et } \\
\text { al., } 2015 \\
\text { (49) } \\
\text { China } \\
\mathrm{N}: 40,510\end{array}$} & $\begin{array}{l}\text { Fish liver oil introduction, } \leq 3 \text { vs } 4 \text { - } \\
6 \mathrm{mo}\end{array}$ & $\begin{array}{l}\text { Overweight at } \\
4-5 y, \text { OR 1.08, } \\
95 \% \mathrm{Cl}: 0.99 \\
1.17, \mathrm{P}=0.004 \\
\text { Obesity, NSA }\end{array}$ & $\begin{array}{l}\text { Higher BMI at 4- } \\
5 y, P<0.001\end{array}$ & & \\
\hline & $\begin{array}{l}\text { Fish liver oil introduction, 4-6 vs. } \\
>6 \mathrm{mo}\end{array}$ & $\begin{array}{l}\text { Overweight at } \\
4-5 y, \text { NSA; } \\
\text { Obesity at 4-5y, } \\
\text { NSA }\end{array}$ & BMI at 4-5y, NSA & & \\
\hline & Egg yolk introduction, $\leq 3$ vs 4-6mo & $\begin{array}{l}\text { Overweight at } \\
4-5 y, \text { NSA; } \\
\text { Obesity at 4-5y, } \\
\text { NSA }\end{array}$ & $\begin{array}{l}\text { Lower BMI at 4- } \\
5 y, P=0.046\end{array}$ & & \\
\hline & $\begin{array}{l}\text { Egg yolk introduction, 4-6 vs. } \\
>6 \mathrm{mo}\end{array}$ & $\begin{array}{l}\text { Overweight at } \\
4-5 y, \text { NSA; } \\
\text { Obesity at 4-5y, } \\
\text { NSA }\end{array}$ & BMI at 4-5y, NSA & & \\
\hline
\end{tabular}


Other foods introduction $\leq 3$ vs 4 $6 \mathrm{mo}$ or $4-6 \mathrm{vs}$. $>6 \mathrm{mo}$ : fish paste, liver paste, tofu, bread/steamed bun/fine dried noodle, or pureed noodle/cookies
Overweight at

4-5y, NSA;

Obesity at $4-5 y$

NSA

1. All studies, except those noted as RCT or non-RCT, followed a prospective cohort design

2. The independent variable/exposure of interest included types and/or amounts of CFB, which encompassed dietary patterns during the complementary feeding period and timing of specific CFB; this section of studies examined various other CFB that did not fit into previously labeled sections such as milk and/or dairy products, vegetables, fruits, egg, and categories such as "ready-made" or "animal source" foods.

3. Outcomes were organized for practicality into columns: weight status, body composition, weight, length or height, and head circumference. Results described in the respective columns are based on outcome similarity and in accordance with the analytical framework as follows: Weight status included risk/incidence/prevalence/frequency of malnutrition, healthy weight, overweight, or obesity; Body composition included measures, indices, and proxies of overall adiposity such as lean mass, fat mass (FM), \% body fat, weight-to-height ratios such as BMI, BMIZ, WLZ, central adiposity or waist circumference, and arm or thigh circumferences; Weight included weight-specific measures such as weight-for-age z-score (WAZ), Length or Height included length-specific measures such as length-for-age z-score (LAZ); Head circumference included head circumference

Abbreviations: BF, breast-fed; CFB, complementary food/beverage; Fe, iron; FF, formula-fed; FM, fat mass; LAZ, length for age z-score; MUAC, mid-upper arm circumference; NR, not reported; NSA, no significant association; NSGD, no significant group differences; RCT, randomized controlled trial; WC, waist circumference; WAZ, weight for age z-score; WLZ, weight for length z-score; Zn, zinc 


\section{Dietary patterns}

Eleven articles examined distinct dietary patterns during the CF period, including one RCT (12) and 10 articles from observational studies (20, 23-25, 28, 34, 41, 42, 46, 47). Dietary patterns at different ages from the same cohort were analyzed in multiple articles as follows: Infant Feeding Practices Study $(42,47)$ and the Southampton Women's Survey $(23,41)$ (see Table 6).

Seven articles from observational studies identified various associations between the dietary patterns examined and growth, size, body composition and/or overweight or obesity status outcomes $(23,28,34,41,42,46,47)$. Results reported in these seven articles are summarized below briefly. Table 6 provides details regarding the specific dietary patterns that were compared and additional information can be found in Supplemental Table 1.

Baird et al. (33) found that adherence to the 'Infant guidelines' pattern at age 6 mo was associated with significantly greater conditional gains in weight and skinfold thickness from 6-12 mo and greater absolute skinfold thickness at 12 mo of age. Infants who were in the highest compared to lowest quartile for scores on the U.K. 'Infant guidelines' pattern at 6 mo gained $\sim 0.12 \mathrm{~kg}$ more weight and $\sim 0.49 \mathrm{~mm}$ more in skinfold thickness from 6-12 mo of age. Greater adherence to the 'Adult foods' pattern at 6 mo was significantly associated with lower weight gain from 6-12 mo of age but not with skinfold thickness (at age 12 mo or gain from 6-12 mo). There were no significant associations between either dietary pattern at $6 \mathrm{mo}$ and weight or length at $12 \mathrm{mo}$ or change in length from 6-12 mo of age.

Robinson et al. (51) reported that greater adherence to the U.K. 'Infant guidelines' pattern at age 12 mo was significantly associated with increased lean mass and lean mass index, but not with BMI, FM, or FMI at 4 y of age.

Rose et al. (52) used latent class analysis to assign infants based on frequency of intake to one of five dietary patterns described in Table 6. Outcomes were assessed based on maternal-report of height and weight. Rose et al. (52) reported that infants in the 'MXHED' group had the highest prevalence of overweight at $1 \mathrm{y}$ of age compared to all other classes. The 'MXHED' and 'FFLV' groups had significantly higher WLZ at 1 $y$ than other classes ('BFLV', 'BFFV', or 'FFFV').

Wen et al. (57) assigned adherence scores to each infant for four dietary patterns at age 6 mo, identified via principal component analysis. Outcomes were assessed based on reported weight and height. Wen et al. (57) found no significant association between adherence to the U.S. 'Infant guideline solids' pattern at 6 mo and change in BMIZ from 6-12 mo. However, greater adherence to the other three patterns at 6 mo was associated with greater change in BMIZ from 6-12 mo. Both the 'High dairy/regular cereal' and 'High sugar/fat/protein' patterns were associated with smaller increases in LAZ from age 6-12 mo.

Golley et al. (44) assigned each infant a CF utility index (CFUI) score at age 6 mo, which was derived and analyzed from dietary pattern scores as a continuous variable from 14 components such as BF duration, age of introduction to solids, textured foods, and minimizing ready-made infant foods. Higher CFUI scores reflected higher adherence to U.K. guidelines for CF. Golley et al. (44) reported that higher CFUI scores at 6 mo were not associated with BMI at $7 \mathrm{y}$ of age but were (weakly) associated with smaller WC at $7 \mathrm{y}$. 
Two articles $(28,46)$ from observational studies reported similar relationships between dietary patterns and wasting (defined according to arm-muscle-area, which was calculated from MUAC and triceps skinfold thickness) and/or malnutrition (defined as WAZ, LAZ, and/or WLZ of less than 2 SD, respectively underweight, stunting, or wasting, according to Thai references). Dagnelie and Staveren found that a 'Macrobiotic' diet compared to 'Omnivorous' diet at age 4-18 mo (see Table \#) was significantly associated with higher wasting, lower weight-for-length, lower weight velocity, lower length velocity, lower MUAC velocity, lower arm muscle area velocity, and lower $\mathrm{HC}$ velocity (37). However, there were no significant differences in crownrump length velocity, triceps or subscapular skinfold thickness velocities $(\mathrm{mm} / \mathrm{y})$, biiliacal width velocity $(\mathrm{cm} / \mathrm{y})$, or arm fat area velocity $\left(\mathrm{mm}^{2} / \mathrm{y}\right)$. Tantrecheewathorn reported that 'Inadequate' compared to 'Adequate' diets (see Table ) were significantly associated with increased relative risk of malnutrition, defined as either underweight, stunted, or wasted (55).

Four articles reported no significant associations between dietary patterns (observed, or derived by analyses) during the CF period and growth, size, and body composition outcomes $(12,20,24,25)$. Results showed no significant differences between the respective dietary patterns examined in each study and the following outcomes examined: (mean or change in) weight, length, HC, or MUAC at 6-12 mo of age (21), overweight/obesity status at $45-48 \mathrm{mo}$ (29); body composition, weight, or length at 4-6 mo (ref 33); or body composition at age 24 mo (34). 
Table 6. Studies that examined dietary patterns during the complementary feeding period and growth, size, and body composition

\begin{tabular}{|c|c|c|c|c|c|c|c|}
\hline $\begin{array}{l}\text { Reference }^{1}, \\
\text { country, analytic } \\
\mathrm{N}\end{array}$ & Dietary patterns ${ }^{2}$ & Comparison & $\begin{array}{l}\text { Results for } \\
\text { weight } \\
\text { status }\end{array}$ & $\begin{array}{l}\text { Results for body } \\
\text { composition }\end{array}$ & $\begin{array}{l}\text { Results for } \\
\text { weight }\end{array}$ & $\begin{array}{l}\text { Results for } \\
\text { length/height }\end{array}$ & $\begin{array}{l}\text { Results for } \\
\text { head } \\
\text { circumference }\end{array}$ \\
\hline $\begin{array}{l}\text { Abraham et al., } \\
2012(20) \\
\text { Scotland } \\
\text { N: } 4493\end{array}$ & $\begin{array}{l}\text { Two dietary patterns } \\
\text { were identified at age } \\
\text { 19-24mo: } \\
\text { 'Negative pattern': } \\
\text { low fruit, vegetable; } \\
\text { high sweets, crisps, } \\
\text { soft drinks, snacking } \\
\text { 'Positive pattern': } \\
\text { high fruit, vegetable; } \\
\text { low snacking }\end{array}$ & $\begin{array}{l}\text { 'Negative' vs. } \\
\text { 'Positive' } \\
\text { pattern }\end{array}$ & $\begin{array}{l}\text { Overweight } \\
\text { or obese at } \\
45-48 m o \text {, } \\
\text { NSA }\end{array}$ & & & & \\
\hline \multirow[t]{2}{*}{$\begin{array}{l}\text { Baird et al., } 2008 \\
\text { (23) } \\
\text { U.K. } \\
\text { N: } 1740\end{array}$} & $\begin{array}{l}\text { Two dietary patterns } \\
\text { were identified at age } \\
6 \text { mo: } \\
\text { 1) 'Infant guidelines': } \\
\text { high frequency of } \\
\text { consumption of } \\
\text { vegetables, fruit, } \\
\text { meat, fish, home- } \\
\text { prepared foods, } \\
\text { breast milk; low } \\
\text { frequency of } \\
\text { consumption of } \\
\text { commercial baby } \\
\text { foods in jars and } \\
\text { formula }\end{array}$ & $\begin{array}{l}\text { Higher vs. } \\
\text { lower quintiles } \\
\text { for 'Infant } \\
\text { guidelines' }\end{array}$ & & $\begin{array}{l}\text { Gain in skinfold age } \\
6-12 \mathrm{mo}, \beta=0.11, \\
95 \% \mathrm{Cl}: 0.04,0.18, \\
P=0.002 ; \\
\text { corresponding to } \\
0.26 \text { SDS; Skinfold } \\
\text { thickness at } 12 \mathrm{mo}, \\
\beta=0.13,95 \% \mathrm{Cl} \text { : } \\
0.01,025, P=0.03\end{array}$ & $\begin{array}{l}\text { Gain in weight } \\
\text { age } 6-12 \mathrm{mo}, \\
\beta=0.10, \\
95 \% \mathrm{Cl}: 0.04, \\
0.17 ; \\
P=0.002, \\
\text { corresponding } \\
\text { to } 0.24 \text { SDS; } \\
\text { Weight at } \\
12 \mathrm{mo}, \mathrm{NSA}\end{array}$ & $\begin{array}{l}\text { Gain in length age } \\
6-12 \mathrm{mo}, \mathrm{NSA} ; \\
\text { Length at } 12 \mathrm{mo} \text {, } \\
\text { NSA }\end{array}$ & \\
\hline & $\begin{array}{l}\text { 2) 'Adult foods': high } \\
\text { frequency of } \\
\text { consumption of } \\
\text { bread, savory } \\
\text { snacks, biscuits, } \\
\text { squash, breakfast } \\
\text { cereals, and crisps; }\end{array}$ & $\begin{array}{l}\text { Higher vs. } \\
\text { lower quintiles } \\
\text { for 'Adult } \\
\text { foods' }\end{array}$ & & $\begin{array}{l}\text { Gain in skinfold age } \\
6-12 \mathrm{mo}, \mathrm{NSA} ; \\
\text { Skinfold thickness at } \\
12 \mathrm{mo}, \mathrm{NSA}\end{array}$ & $\begin{array}{l}\text { Gain in weight } \\
\text { age 6-12mo, } \\
\beta=-0.08, \\
95 \% \mathrm{Cl}:-0.15 \text {, } \\
-0.02, \\
P=0.0015 ; \\
\text { Weight at }\end{array}$ & $\begin{array}{l}\text { Gain in length age } \\
6-12 \mathrm{mo}, \mathrm{NSA} ; \\
\text { Length at } 12 \mathrm{mo} \text {, } \\
\text { NSA }\end{array}$ & \\
\hline
\end{tabular}


breast milk, baby

rice, and cooked and

canned fruit

\begin{tabular}{|c|c|c|c|c|c|c|}
\hline $\begin{array}{l}\text { Barton et al., } 2002 \\
\text { (24) } \\
\text { U.S. } \\
\text { N: } 52\end{array}$ & 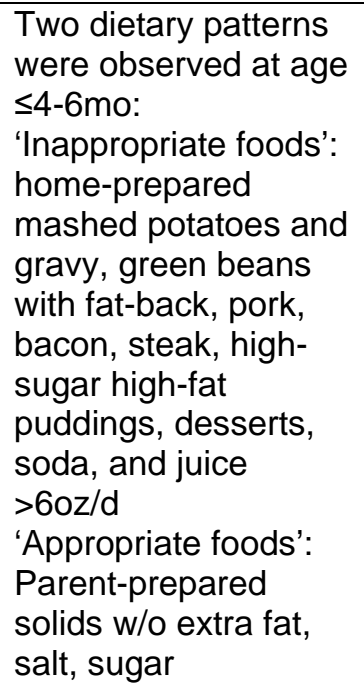 & $\begin{array}{l}\text { 'Inappropriate' } \\
\text { vs. } \\
\text { 'Appropriate' }\end{array}$ & & $\begin{array}{l}\text { Weight at 4- } \\
6 \mathrm{mo}, \mathrm{NSA}\end{array}$ & $\begin{array}{l}\text { Length at 4-6mo, } \\
\text { NSA }\end{array}$ & $\begin{array}{l}\mathrm{HC} \text { at } 4-6 \mathrm{mo} \text {, } \\
\text { NSA }\end{array}$ \\
\hline $\begin{array}{l}\text { Bell et al., } 2013 \\
\text { (25) } \\
\text { Australia } \\
\text { N: } 493\end{array}$ & $\begin{array}{l}\text { Four dietary patterns } \\
\text { were identified at age } \\
\text { 13-16mo: } \\
\text { 'Core': fruit, grains, } \\
\text { nonwhite bread, } \\
\text { vegetables, cheese, } \\
\text { eggs, nuts and seeds } \\
\text { 'Basic combination': } \\
\text { basic core + non-core } \\
\text { w/o fruit or } \\
\text { vegetables } \\
\text { 'Basic core': white } \\
\text { bread, milk } \\
\text { 'Non-core': spreads, } \\
\text { juice, ice-cream }\end{array}$ & $\begin{array}{l}\text { Each pattern } \\
\text { relative to } \\
\text { outcomes }\end{array}$ & BMIZ at 24mo, NSA & & & \\
\hline
\end{tabular}




\begin{tabular}{|c|c|c|c|c|c|c|c|}
\hline $\begin{array}{l}\text { Dagnelie and van } \\
\text { Staveren, } 1994 \text { (28) } \\
\text { Netherlands } \\
\text { N: } 106\end{array}$ & $\begin{array}{l}\text { Two dietary patterns } \\
\text { were observed at } \\
\text { ages 4-10mo } \\
\text { 'Macrobiotic diet': } \\
\text { Included unpolished } \\
\text { rice, pulses and } \\
\text { vegetables with a } \\
\text { high fiber content, } \\
\text { small additions of } \\
\text { seaweeds, fermented } \\
\text { foods, nuts, seeds, } \\
\text { and seasoned foods; } \\
\text { Avoided vit. D } \\
\text { supplements, } \\
\text { products of animal } \\
\text { origin such as meat } \\
\text { and dairy product, } \\
\text { fat/oil, and fish. } \\
\text { 'Omnivorous diet': } \\
\text { Not described }\end{array}$ & $\begin{array}{l}\text { 'Macrobiotic } \\
\text { 'vs. } \\
\text { 'Omnivorous' }\end{array}$ & $\begin{array}{l}\text { Wasting } \\
30 \% \text { vs. } \\
2 \% \\
P<0.001\end{array}$ & $\begin{array}{l}\text { MUAC velocity, } 1.0 \\
\text { vs. } 2.3 \mathrm{~cm} / \mathrm{y}, \mathrm{P}< \\
0.01 ; \text { Smaller arm } \\
\text { muscle area } \\
\text { velocity, } 413 \text { vs. } 624 \\
\mathrm{~mm}^{2} / \mathrm{y}, \mathrm{P}<0.01 ; \\
\text { Slower weight-for- } \\
\text { length, P<0.05. } \\
\text { Triceps or } \\
\text { subscapular skinfold } \\
\text { thickness velocities, } \\
\text { NSA; biiliacal width } \\
\text { velocity, NSA; arm } \\
\text { fat area velocity, } \\
\text { NSA }\end{array}$ & $\begin{array}{l}\text { Weight } \\
\text { velocity, } 3.3 \\
\text { vs. } 4.4 \mathrm{~kg} / \mathrm{y} \text {, } \\
\mathrm{P}<0.001\end{array}$ & $\begin{array}{l}\text { Length velocity, } 13.2 \\
\text { vs. } 16.7 \mathrm{~cm} / \mathrm{y}, \\
\mathrm{P}<0.001 ; \text { Crown- } \\
\text { rump length velocity, } \\
\text { NSA }\end{array}$ & $\begin{array}{l}\text { Lower HC } \\
\text { velocity, } 5.2 \text { vs. } \\
6.1 \mathrm{~cm} / \mathrm{y} . \mathrm{P}< \\
0.05\end{array}$ \\
\hline $\begin{array}{l}\text { Golley et al., } 2013 \\
\text { (34) } \\
\text { U.K. } \\
\text { N: } 7834\end{array}$ & $\begin{array}{l}\text { Each infant received } \\
\text { a CFUI score at age } \\
6 \text { mo, derived and } \\
\text { analyzed as a } \\
\text { continuous variable } \\
\text { from } 14 \text { components } \\
\text { such as BF duration, } \\
\text { textured foods, and } \\
\text { minimizing ready- } \\
\text { made infant foods }\end{array}$ & $\begin{array}{l}\text { CFUI scores } \\
\text { (higher scores } \\
\text { reflected } \\
\text { higher } \\
\text { adherence to } \\
\text { CF } \\
\text { guidelines) }\end{array}$ & & $\begin{array}{l}\text { BMI at } 7 y, N S A ; W C \\
\text { at } 7 y: \beta=-0.15,95 \% \\
C l:-0.31,-0.002, \\
P=0.046\end{array}$ & & & \\
\hline $\begin{array}{l}\text { Olaya et al., } 2013 \\
(12) \\
\text { RCT; Colombia } \\
\text { N: } 76\end{array}$ & $\begin{array}{l}\text { Intervention group: } \\
\text { individual, face-to- } \\
\text { face nutrition } \\
\text { counseling with } 3 \text { key } \\
\text { messages, 1) the } \\
\text { importance of } \\
\text { continuing BF } \\
\text { alongside CFB, 2) } \\
\text { red meat as a source }\end{array}$ & $\begin{array}{l}\text { Intervention } \\
\text { vs. Control }\end{array}$ & & $\begin{array}{l}\text { MUAC at } 12 \mathrm{mo} \text {, } \\
\text { NSGD; Change in } \\
\text { MUAC 6-12mo, } \\
\text { NSGD }\end{array}$ & $\begin{array}{l}\text { Mean WAZ at } \\
\text { 12mo, NSGD; } \\
\text { Change in } \\
\text { WAZ 6-12mo, } \\
\text { NSGD }\end{array}$ & $\begin{array}{l}\text { Mean LAZ at } 12 \mathrm{mo} \text {, } \\
\text { NSGD; Change in } \\
\text { LAZ 6-12mo, NSGD }\end{array}$ & $\begin{array}{l}\text { HC at } 12 \mathrm{mo}, \\
\text { NSGD; } \\
\text { Change in HC } \\
6-12 \mathrm{mo}, \mathrm{NSGD}\end{array}$ \\
\hline
\end{tabular}




\begin{tabular}{|c|c|c|c|c|c|}
\hline & $\begin{array}{l}\text { of Fe to prevent } \\
\text { anemia (>5 } \\
\text { portions/wk, red } \\
\text { meat, chicken liver } \\
\text { and heart), and 3) } \\
\text { daily fruit and } \\
\text { vegetables as part of } \\
\text { a healthy diet from } \\
\text { ages 6-12mo } \\
\text { Control group: } \\
\text { standard CF advice } \\
\text { from health care } \\
\text { professionals on } \\
\text { meat consumption, } \\
\text { but no advice on } \\
\text { frequency or amount } \\
\text { of foods was given, } \\
\text { from ages 6-12mo }\end{array}$ & & & & \\
\hline $\begin{array}{l}\text { Robinson et al., } \\
2009 \text { (Robinson, } \\
2009 \text { ) } \\
\text { U.K. } \\
\text { N: } 536\end{array}$ & $\begin{array}{l}\text { One dietary pattern } \\
\text { was identified at age } \\
\text { 12mo: } \\
\text { 'Infant guidelines' } \\
\text { pattern: High } \\
\text { consumption of fruit, } \\
\text { vegetables, cooked } \\
\text { meat and fish, and } \\
\text { other home-prepared } \\
\text { foods (rice, pasta), } \\
\text { and low consumption } \\
\text { of commercial baby } \\
\text { foods }\end{array}$ & $\begin{array}{l}\text { Higher vs. } \\
\text { lower 'Infant } \\
\text { guidelines' . } \\
\text { scores }\end{array}$ & & $\begin{array}{l}\text { Increased lean } \\
\text { mass at } 4 \mathrm{y}, \\
\mathrm{P}=0.003 ; \text { Increased } \\
\text { lean mass index at } \\
4 \mathrm{y}, \mathrm{P}=0.004 ; \mathrm{BMI}, \\
\text { FM, or FMI at } 4 \mathrm{y}, \\
\text { NSA }\end{array}$ & \\
\hline $\begin{array}{l}\text { Rose et al., } 2016 \\
(42) \\
\text { U.S. } \\
\text { N: } 1029\end{array}$ & $\begin{array}{l}\text { Five dietary patterns } \\
\text { were identified at age } \\
9 \text { mo: } \\
\text { BFFV, 'Breastfed } \\
\text { Fruits and } \\
\text { Vegetables': } \\
\text { Breastmilk, fruits, and } \\
\text { vegetables, and low }\end{array}$ & $\begin{array}{l}\text { Each pattern } \\
\text { relative to } \\
\text { outcomes }\end{array}$ & $\begin{array}{l}\text { Prevalence } \\
\text { of } \\
\text { overweight } \\
\text { at 1y } \\
\text { highest for } \\
\text { MXHED } \\
\text { relative to } \\
\text { prevalence }\end{array}$ & $\begin{array}{l}\text { WLZ at 1y: BFFV: } \\
0.09 ; \text { BFLV: }-0.02 ; \\
\text { FFFV: } 0.47 ; \text { FFLV: } \\
0.70, \text { MXHED: } 0.74 \\
\text { P<0.01 }\end{array}$ & $\begin{array}{l}\text { WAZ at 1y: } \\
\text { BFFV: }-0.30 ; \\
\text { BFLV: }-0.60 ; \\
\text { FFFV: }-0.06 ; \\
\text { FFLV: }-0.11 \\
\text { MXHED: }- \\
0.10 . P<0.001\end{array}$ \\
\hline
\end{tabular}




\begin{tabular}{|c|c|c|c|}
\hline & $\begin{array}{l}\text { intake of energy- } \\
\text { dense foods } \\
\text { BFLV, 'Breastfed Low } \\
\text { Variety': Breastmilk, } \\
\text { and low intake of } \\
\text { fruits and vegetables, } \\
\text { low diet variety } \\
\text { FFFV, 'Formula-Fed } \\
\text { Fruits and } \\
\text { Vegetables': } \\
\text { Formula, fruits, and } \\
\text { vegetables, and low } \\
\text { intake of energy- } \\
\text { dense foods } \\
\text { FFLV, 'Formula-Fed } \\
\text { Low Variety': } \\
\text { Formula, and low } \\
\text { intake of fruits and } \\
\text { vegetables, low diet } \\
\text { variety } \\
\text { MXHED, 'Mixed High } \\
\text { Energy Density': } \\
\text { Breastmilk and } \\
\text { formula, low intake of } \\
\text { fruits and vegetables, } \\
\text { diet variety, and } \\
\text { higher intake of } \\
\text { energy-density foods } \\
\text { (e.g. french fries, } \\
\text { sweet foods) }\end{array}$ & & $\begin{array}{l}\text { for BFFV, } \\
\text { BFLV, } \\
\text { FFFV, } \\
\text { FFLV, } \\
\text { values NR }\end{array}$ \\
\hline $\begin{array}{l}\text { Tantracheewathorn, } \\
2005(46) \\
\text { Thailand } \\
\text { N: } 140\end{array}$ & $\begin{array}{l}\text { Two dietary patterns } \\
\text { were observed prior } \\
\text { to age } 12 \mathrm{mo} \text { : } \\
\text { 'Adequate' CFB: } \\
\text { consumed a variety } \\
\text { of food from various } \\
\text { food groups (rice and } \\
\text { grains, fruits, } \\
\text { vegetables, milk, } \\
\text { meat, eggs, fat), and }\end{array}$ & $\begin{array}{l}\text { 'Inadequate' } \\
\text { vs. 'Adequate' }\end{array}$ & $\begin{array}{l}\text { Malnutrition, } \\
\text { OR 4.7, } \\
95 \% \mathrm{Cl}: 1.1 \text {, } \\
21.9, \\
\mathrm{P}=0.04\end{array}$ \\
\hline
\end{tabular}


adequate amounts of

nutrient and energy

compared with Thai

Recommended

Dietary Allowances

'Inadequate' CFB: not

described

\begin{tabular}{|c|c|c|c|c|}
\hline $\begin{array}{l}\text { Wen et al., } 2014 \\
\text { (47) } \\
\text { U.S. } \\
\text { N: } 530\end{array}$ & $\begin{array}{l}\text { Four dietary patterns } \\
\text { were identified at age } \\
6 \text { mo: } \\
\text { 'Infant guideline } \\
\text { solids': Baby cereal, } \\
\text { fruit, vegetables, } \\
\text { meat/chicken } \\
\text { 'High } \\
\text { sugar/fat/protein': } \\
\text { Sweet drinks, french } \\
\text { fries, fish/shellfish, } \\
\text { nut foods, eggs, } \\
\text { sweet foods } \\
\text { 'High dairy/regular } \\
\text { cereal': Cow's milk, } \\
\text { other dairy, 100\% } \\
\text { juice, non-baby } \\
\text { cereals/starches } \\
\text { 'Formula': Formula, } \\
\text { low intakes of breast } \\
\text { milk }\end{array}$ & $\begin{array}{l}\text { Each pattern } \\
\text { relative to } \\
\text { outcomes }\end{array}$ & $\begin{array}{l}\text { Change in BMIZ } \\
\text { from age } 6-12 \mathrm{mo} \text { : } \\
\text { High } \\
\text { sugar/fat/protein } \\
\text { pattern: } \beta=1.00 \text {, } \\
95 \% \mathrm{Cl} \text { : } 0.11,1.89 \text {; } \\
\text { Infant guideline } \\
\text { solids: } \beta=0.06, \\
\text { 95\%Cl: }-0.09,0.22 \text {; } \\
\text { Formula } \beta=0.25 \text {, } \\
95 \% \mathrm{Cl}: 0.09,0.40 ; \\
\text { High dairy/regular } \\
\text { cereal } \beta=0.32, \\
95 \% \mathrm{Cl}: 0.10,0.53\end{array}$ & $\begin{array}{l}\text { Change in LAZ from } \\
\text { age } 6-12 \text { mo, High } \\
\text { sugar/fat/protein } \\
\text { pattern: } \beta=-1.36, \\
\text { 95\%Cl: }-2.35,-0.37 \text {; } \\
\text { Infant guideline } \\
\text { solids: } \beta=0.12 \text {, } \\
\text { 95\%Cl: }-0.05,0.29 ; \\
\text { Formula } \beta=0.01, \\
\text { 95\%Cl: }-0.16,0.18 ; \\
\text { High dairy/regular } \\
\text { cereal } \beta=-0.30, \\
\text { 95\%Cl: }-0.54,-0.06\end{array}$ \\
\hline
\end{tabular}

1. All studies, except those noted as RCT or non-RCT, followed a prospective cohort design

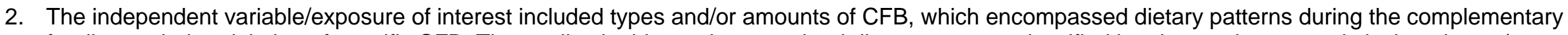
feeding period and timing of specific CFB; The studies in this section examined dietary patterns classified by observation or statistical analyses (e.g., adherence scores derived from latent class, cluster, or principal component analysis)

3. Outcomes were organized for practicality into columns: weight status, body composition, weight, length or height, and head circumference. Results described in the respective columns are based on outcome similarity and in accordance with the analytical framework as follows: Weight status included risk/incidence/prevalence/frequency of malnutrition, healthy weight, overweight, or obesity; Body composition included measures, indices, and proxies of overall adiposity such as lean mass, fat mass (FM), \% body fat, weight-to-height ratios such as BMI, BMIZ, WLZ, central adiposity or waist circumference, and arm or thigh circumferences; Weight included weight-specific measures such as weight-for-age z-score (WAZ), Length or Height 
included length-specific measures such as length-for-age z-score (LAZ), linear velocity; Head circumference included head circumference.

Abbreviations: BF, breast fed; BFFV, breast fed fruits and vegetables pattern; BFLV, breast fed low variety pattern; CFB, complementary food/beverage; CFUI, complementary feeding utility index; Fe, iron; FF, formula-fed; FFFV, formula-fed fruits and vegetables pattern; FFLV, formula-fed low variety pattern; FM, fat mass; FMI, fat mass index; LAZ, length for age z-score; MUAC, mid-upper arm circumference; MXHED, mixed high energy density pattern; NR, not reported; NSA, no significant association; NSGD, no significant group differences; RCT, randomized controlled trial; SSB, sugarsweetened beverage; WC, waist circumference; WAZ, weight for age z-score; WLZ, weight for length z-score 


\section{Discussion}

\section{Meat}

Moderate evidence indicates that higher versus lower meat intake or meat versus Fefortified cereal intake over a short duration ( $-3 \mathrm{mo})$ during the CF period does not favorably or unfavorably influence growth, size, or body composition. There is insufficient evidence to determine a relationship between meat intake and prevalence/incidence of overweight or obesity. Despite the majority of evidence coming from well-designed RCTs, these studies were not necessarily designed to determine the effects of adequate or inadequate amounts of meat consumption on growth-related outcomes. For example, the objective of Yeung and Zlotkin (18) was to prevent iron depletion in cow's milk-fed infants by testing CFBs that are higher in iron content, and collected anthropometric measurements mainly to ensure that growth was not impaired during the trial. Among the trials, there are several important methodological limitations such as short durations $\sim 3 \mathrm{mo}$, variable length of follow-up, relatively small sample sizes, insufficiently described data, statistical analyses, and/or outcome assessment methods. Findings from one study in China may be less generalizable due to participants coming from a rural community with high rates of stunting (15). All of the RCTs reported outcomes prior to $18 \mathrm{mo}$ of age and therefore do not provide information on growth, size, or body composition later in childhood.

Five studies (two RCTs and three observational studies) examined the amount of meat given and BMI only, weight only, or weight and other outcomes. Neither of the trials assessed the impact of high loss to follow-up or provided sufficient detail to determine the reliability/validity of outcome assessment $(2,3)$ and did not adjust for baseline differences between groups (3), or did not report results for all potential outcomes (2). Observational studies pointed to positive relationships between meat intake and outcomes but varied in terms of when meat intake was examined, how outcomes were assessed, and did not adjust analyses for potential key confounders (SES, maternal age, or gestational age).

\section{Cereal}

Limited evidence suggests that type or amount of cereal given does not favorably or unfavorably influence growth, size, body composition, and/or prevalence/incidence of overweight or obesity. Results from six studies (3 RCTs) provided little evidence of a strong relationship between the type or amount of cereal and the outcomes assessed. Studies varied considerably in the type or amount of cereal provided (e.g., wheat/soy vs. wheat/milk fortified weaning cereal; Fe-fortified vs. non-fortified cereal) and outcomes examined. Limitations include a lack of description regarding statistical methods, potential impact of unintended exposures due to other CFB consumed, indirectness, failure to adjust statistical analyses for multiple comparisons, and limited generalizability.

\section{CFB with different fats/ fatty acid composition}

Moderate evidence suggests that consumption of complementary foods with different fats and/or fatty acid composition does not favorably or unfavorably influence growth, size, or body composition although there is not enough evidence regarding overweight or obesity specifically. There was variation in the different CFB and/or fats/fatty acids 
tested $(4,6,10,13)$, with two studies examining egg-yolk as sources of DHA, one examining fish, and another examining a CFB meal with fatty-acids from different oil sources. None of the studies examined outcomes at ages older than 24 mo. Most of the articles lacked sufficient description of outcome assessment methods and therefore, the validity/reliability of outcomes could not be determined. Two articles did not account for high loss to follow-up $(6,13)$. One of the RCTs may not have been adequately powered to detect differences in growth (13).

\section{SSBs.}

Limited evidence suggests that SSB consumption during the CF period is associated with increased risk of obesity in childhood, but is not associated with other measures of growth, size, and body composition. Two studies examined the relationship between SSB consumption during the CF period and risk of obesity in childhood. One of those two studies demonstrated significant increased risk of obesity in childhood and was weighed more heavily than the other study due to its strength including sample size and adjustment for potential confounders. Three studies examined the relationship between SSB consumption during the CF period and other outcomes (BMI, BMI trajectory, BMIZ, and WC) in childhood, with all finding no significant associations with these other measures. The relationship between early introduction of SSBs in the CF period and later childhood overweight or obesity could reflect unmeasured confounding factors. A stronger conclusion could not be drawn due to an inadequate number of studies (all were observational), inconsistencies in how SSBs were examined (e.g., age of introduction of SSBs), and lack of information on quantities consumed.

\section{Juice drinks and $\mathbf{1 0 0 \%}$ juice.}

Limited evidence suggested a significant positive association between juice intake and infant weight-for-length and child BMI z-scores. However, there is not enough evidence to determine the relationship between juice intake and other outcomes (i.e., growth, size, and/or body composition). The evidence came from only a few observational studies, most of which examined juice intake without describing the type of fruit or \% of fruit juice in the juice, although one study specified orange juice or other $100 \%$ fruit juice (45). Notably, there were a few positive and significant associations observed between juice intake in relatively large amounts (e.g., 8-15 oz) or at young ages (e.g., at $9 \mathrm{mo}$ ) and WLZ, BMIZ, or WAZ. There was variation in types and age of outcomes assessed across studies, with most reporting weight relative to length outcomes (e.g., WLZ, BMI) at different ages. The reliability/validity of measures for outcome assessment could not be determined in several of these studies because weight and/or length was obtained from maternal report, unstandardized methods, or was not reported.

\section{Other CFB}

No conclusion could be made about the relationship between other CFB (vegetables, fruit, dairy products and/or cow's milk, cereal-based products, milk-cereal drink, and/or categories such as "ready-made" foods) and growth, size, body composition, and/or prevalence/incidence of overweight or obesity. This was primarily due to heterogeneity in study design and the types of other CFB examined (e.g., distinct CFB such as cow's milk, MCD, vegetables, fruit, tofu, biscuits/breads, and/or groupings such as dairy products, animal source foods, sweetened/confectionary foods, 'mixed' foods, and 
'ready-made' foods). The majority of evidence was observational, although data were included from several RCTs and one non-RCT. There were also the following:

- limited generalizability to the U.S. population due to CFB used or CF practices at the time of the study,

- inadequacy of statistical methods regarding adjustment for multiple comparisons,

- indirectness with which some studies examined the link between types or amounts of other CFB and outcomes,

- variation in outcome types and assessment methods, and

- inconsistency in which analyses were adjusted for potential confounders (e.g., SES, race and/or ethnicity, feeding practices, or birth size).

\section{Dietary patterns}

No conclusion could be made about the relationship between distinct dietary patterns during the CF period and growth, size, body composition, or prevalence/incidence of malnutrition, overweight or obesity (Table 8). The conflicting evidence precludes the ability to draw a conclusion due to heterogeneous analyses of dietary patterns. The studies were difficult to compare and contrast due to the wide variation in the specific dietary patterns compared, as well as the outcomes assessed. In several cases, the labelling of dietary patterns carried judgement (e.g., 'Inappropriate' or 'Inadequate'), which may or may not correspond to evidence-based infant feeding.

Several articles examined the relationship between dietary patterns that align with CF guidelines and growth, size, and/or body composition outcomes. Although some studies emphasized fruits, vegetables, and meats in a pattern labelled "Infant guidelines', there were differences in other emphasized foods, such as baby cereal (56) or commercial baby food (50), across other patterns. Several articles identified dietary patterns that do not clearly align with CF guidelines and varied widely in specific foods or food groups included (e.g., high frequency of french fries, sweet foods, fish/shellfish, nut foods, and eggs (47) compared to bread, snacks, crisps, breakfast cereals and low frequency of human milk and cooked/canned fruit (23)). These prospective studies are likely confounded by unmeasured factors that may differ between families that follow infant feeding guidelines vs. those who do not. For example, families that adhere to infant feeding guidelines may choose healthier diets and lifestyles (e.g. physical activity) later in the child's upbringing.

The results from Dagnelie and van Staveren (37) and Tantracheewathorn (55) are less generalizable to the U.S. population due to the types of dietary patterns examined (i.e., 'Macrobiotic' vs. 'Omnivorous'; 'Inadequate' vs. 'Adequate'). Neither of these observational studies adjusted for several confounding factors nor provided sufficient detail regarding comparison diets (e.g., 'Omnivorous'; 'Inadequate'). The relationship between dietary patterns during the CF period and overweight or obesity status was examined in two articles from observational studies, which varied in the specific dietary patterns assessed and reported inconsistent results.

\section{Limitations}

Across the entire body of evidence, there were concerns surrounding methodological limitations and internal validity. One methodological limitation across most of the 
observational studies includes the potential for reverse causality. That is, the child may already be growing faster or slower when decisions regarding feeding frequency, types, or amounts of CFB are made. Another limitation includes the variability in controlling for confounding factors. While most studies did account for infant milkfeeding practices, the majority of observational studies (22 of 30) did not adjust for two or more key confounders (see Figure 1 ). Most of the RCTs enrolled infants who were $\operatorname{EBF}(4,5,11-15,17)$ or $\operatorname{EFF}(1,9)$ to 4 mo of age or older.

With few exceptions, the included studies were not designed to evaluate different amounts of CFB but rather varying types of CFB relative to outcomes. In addition, many studies were designed to test the influence of CFB in relation to outcomes other than those of interest in this SR. For example, several studies aimed to test the influence of Fe-fortified cereal on iron status, using anthropometric measures as secondary outcomes. In many cases, the amount of CFB provided would not be expected to affect growth and body composition over the duration in which it was tested. Several studies examined timing of specific types of CFB as opposed to more directly comparing different types and/or amounts of CFB in relation to growth outcomes $(22,26,29,30,38,43,44,49)$.

Most of the studies examined outcomes at multiple time points or assessed change over time to capture growth. However, a few trials $(3,6,10)$ and many observational studies $(20,22,25,29,31,34,41-43,47-49)$ examined outcomes at only a single time point. Of those studies, all of the observational studies adjusted analyses for baseline or current anthropometric status $(25,29,34,47,49)$, or birth weight $(20,31,41-43$, 49). Engelmann (3) reported differences between groups in baseline anthropometrics that were not accounted for in analyses. Both Libuda et al. (6) and Makrides et al. (10) lacked sufficient detail regarding outcome assessment, though Libuda et al. (6) reported no differences in birth weight between groups at baseline.

Another limitation is the limited reliability/validity of assessment methods for both outcome assessment and assessment of types and/or amounts of CFB. Several studies used weight/height that was reported weight/height, not measured, from various sources $(31,40,42,44,47)$, did not fully describe their methods for assessing all outcomes $(10,13,17,20,24,35,49)$, or used unstandardized methods $(2,37,38)$.

Several authors of the RCTs noted limitations regarding insufficient sample size/power and/or did not assess the impact of high loss to follow-up (2, 3, 6, 13, 16-18). Most of the observational studies had adequate sample sizes to investigate the relationship between types and/or amounts of CFB and outcomes although 15 (of 30) did not account for missing data/high attrition rates. Adequacy of statistical methods in several of the RCTs was insufficient due to a lack of detail describing data in analyses or figures $(9,17,19,27,46)$. Adequacy of statistical methods in several of the observational studies could not be determined due to insufficient description and/or lack of statistical correction for multiple comparisons $(32,33,35,44,49)$. In many of the RCTs, blinding of investigators could not be determined and participants were not blinded due to receipt of specific types and/or amounts of CFB. Blinding of outcome assessors could not be determined in the majority of the observational studies 


\section{Research recommendations}

In order to better understand the relationship between types and/or amounts of CFB and growth, size, body composition, and/or risk of overweight or obesity, future research should consider:

- Rigorous study designs that directly examine the effects of specific types and amounts of CFB such as fruits, vegetables, meat, cereal, oil sources of fat/fatty acids, and dairy products on multiple growth-related outcomes over longer duration of intervention and follow-up.

- Evidence examining foods that may be historically non-traditional complementary foods in settings such as the U.S. (e.g., legumes, nuts and seeds).

- Additional observational evidence regarding consumption of CFB that are not nutrient-dense (e.g., contain added sugars, refined starches, or solid fats) during the CF period, which may influence energy balance, growth, and development

- Sufficient breadth and depth of duration of follow-up to determine short- and long-term influences of CFB on growth, size, and body composition (i.e., multiple studies that examine the relationship between types and amounts of CFB consumed and outcomes shortly after the CF period as well as into childhood, adolescence, and adulthood).

- Consistency across research investigating dietary patterns during the CF period, with respect to labeling dietary patterns (avoiding judgements about "adequacy"), analytical methods used to derive and assign patterns, foods and food groupings included; and documentation of human milk and/or formula intake.

Additional adjustments in observational studies to the extent possible for confounding factors, including: parental education, socioeconomic status, child sex, maternal age, race/ethnicity, feeding practices including dietary intake/patterns between baseline and follow-up, birth size, gestational age, baseline growth status.

\section{Included articles}

1. Davidsson, L, Mackenzie, J, Kastenmayer, $P$, et al. Dietary fiber in weaning cereals: a study of the effect on stool characteristics and absorption of energy, nitrogen, and minerals in healthy infants. Journal of pediatric gastroenterology and nutrition. 1996;22(2):167-79.

2. Dube, K, Schwartz, J, Mueller, M J, et al. Complementary food with low (8\%) or high (12\%) meat content as source of dietary iron: a double-blinded randomized controlled trial. European journal of nutrition. 2010;49(1):11-8.

3. Engelmann, M D, Sandstrom, B, Michaelsen, K F. Meat intake and iron status in late infancy: an intervention study. Journal of pediatric gastroenterology and nutrition. 1998;26(1):26-33.

4. Hoffman, D R, Theuer, R C, Castaneda, Y S, et al. Maturation of visual acuity is accelerated in breast-fed term infants fed baby food containing DHA-enriched egg yolk. The Journal of nutrition. 2004;134(9):2307-13.

5. Krebs, N F, Westcott, J E, Butler, N, et al. Meat as a first complementary food for breastfed infants: feasibility and impact on zinc intake and status. Journal of pediatric gastroenterology and nutrition. 2006;42(2):207-14. 
6. Libuda, L, Mesch, C M, Stimming, M, et al. Fatty acid supply with complementary foods and LC-PUFA status in healthy infants: results of a randomised controlled trial. European journal of nutrition. 2015.

7. Lind T, Persson L, Lonnerdal B, Stenlund H, Hernell O. Effects of weaning cereals with different phytate content on growth, development and morbidity: a randomized intervention trial in infants from 6 to 12 months of age. Acta paediatrica (Oslo, Norway: 1992). 2004;93(12):1575-82.

8. Liu, D S, Bates, C J, Yin, T A, et al. Nutritional efficacy of a fortified weaning rusk in a rural area near Beijing. The American journal of clinical nutrition. 1993;57(4):506-11. 9. Lonnerdal, B, Chen, C L. Effects of formula protein level and ratio on infant growth, plasma amino acids and serum trace elements. II. Follow-up formula. Acta paediatrica Scandinavica. 1990;79(3):266-73.

10. Makrides, M, Hawkes, J S, Neumann, M A, et al. Nutritional effect of including egg yolk in the weaning diet of breast-fed and formula-fed infants: a randomized controlled trial. The American journal of clinical nutrition. 2002;75(6):1084-92.

11. Makrides, M, Leeson, R, Gibson, Rap, et al. A randomized controlled clinical trial of increased dietary iron in breast-fed infants. The Journal of pediatrics. 1998;133(4):559-62. 12. Olaya, G A, Lawson, M, Fewtrell, M S. Efficacy and safety of new complementary feeding guidelines with an emphasis on red meat consumption: a randomized trial in Bogota, Colombia. The American journal of clinical nutrition. 2013;98(4):983-93.

13. Schwartz, J, Dube, K, Sichert H, W, et al. Modification of dietary polyunsaturated fatty acids via complementary food enhances n-3 long-chain polyunsaturated fatty acid synthesis in healthy infants: a double blinded randomised controlled trial. Archives of disease in childhood. 2009;94(11):876-82.

14. Tang, M, Krebs, N F. High protein intake from meat as complementary food increases growth but not adiposity in breastfed infants: a randomized trial. The American journal of clinical nutrition. 2014;100(5):1322-8.

15. Tang, $M$, Sheng, $X Y, K$ rebs, N F, et al. Meat as complementary food for older breastfed infants and toddlers: a randomized, controlled trial in rural China. Food and nutrition bulletin. 2014;35(4 Suppl):S188-92.

16. Virtanen MA, Svahn CJ, Viinikka LU, Raiha NC, Siimes MA, Axelsson IE. Ironfortified and unfortified cow's milk: effects on iron intakes and iron status in young children. Acta paediatrica (Oslo, Norway : 1992). 2001;90(7):724-31.

17. Walter, T, Dallman, P R, Pizarro, F, et al. Effectiveness of iron-fortified infant cereal in prevention of iron deficiency anemia. Pediatrics. 1993;91(5):976-82.

18. Yeung, G S, Zlotkin, S H. Efficacy of meat and iron-fortified commercial cereal to prevent iron depletion in cow milk-fed infants 6 to 12 months of age: a randomized controlled trial. Canadian journal of public health $=$ Revue canadienne de sante publique. 2000;91(4):263-7.

19. de Silva, D G, Rajindrajith, S, Pathmeswaran, A, et al. An intervention study to monitor weight gain in infants using a home based complementary food recipe and a hand blender. The Ceylon medical journal. 2007;52(3):79-83.

20. Abraham, E C, Godwin, J, Sherriff, A, et al. Infant feeding in relation to eating patterns in the second year of life and weight status in the fourth year. Public health nutrition. 2012;15(9):1705-14.

21. Almquist T, G, Dahlgren, J, Roswall, J, et al. Milk cereal drink increases BMI risk at 12 and 18 months, but formula does not. Acta paediatrica (Oslo, Norway : 1992).

2013;102(12):1174-9. 
22. Ay, L, Hokken K, A C, Mook K, D O, et al. Tracking and determinants of subcutaneous fat mass in early childhood: the Generation R Study. International journal of obesity (2005). 2008;32(7):1050-9.

23. Baird, J, Poole, J, Robinson, S, et al. Milk feeding and dietary patterns predict weight and fat gains in infancy. Paediatric and perinatal epidemiology. 2008;22(6):575-86. 24. Barton, S J, Howard, P K, Rayens, M K. The effects of infant feeding decisions on infant growth. Journal for specialists in pediatric nursing : JSPN. 2002;7(2):64-70.

25. Bell, L K, Golley, R K, Daniels, L, et al. Dietary patterns of Australian children aged 14 and 24 months, and associations with socio-demographic factors and adiposity. European journal of clinical nutrition. 2013;67(6):638-45.

26. Cantoral, A, Tellez R, M M, Ettinger, A S, et al. Early introduction and cumulative consumption of sugar-sweetened beverages during the pre-school period and risk of obesity at 8-14 years of age. Pediatric obesity. 2016;11(1):68-74.

27. Carruth BR, Skinner JD, Houck KS, Moran JD. Addition of supplementary foods and infant growth (2 to 24 months). Journal of the American College of Nutrition. 2000;19:40512.

28. Dagnelie, P C, van S, W A. Macrobiotic nutrition and child health: results of a population-based, mixed-longitudinal cohort study in The Netherlands. The American journal of clinical nutrition. 1994;59(5 Suppl):1187s-96s.

29. Durmus, B, Heppe, D H, Gishti, O, et al. General and abdominal fat outcomes in school-age children associated with infant breastfeeding patterns. The American journal of clinical nutrition. 2014;99(6):1351-8.

30. Durmus B, Ay L, Duijts L, Moll HA, Hokken-Koelega AC, Raat H, et al. Infant diet and subcutaneous fat mass in early childhood: the Generation R Study. European journal of clinical nutrition. 2012;66:253-60.

31. Gaffney, K F, Kitsantas, P, Cheema, J. Clinical practice guidelines for feeding behaviors and weight-for-age at 12 months: a secondary analysis of the Infant Feeding Practices Study II. Worldviews on evidence-based nursing / Sigma Theta Tau International, Honor Society of Nursing. 2012;9(4):234-42.

32. Garden, F L, Marks, G B, Simpson, J M, et al. Body mass index (BMI) trajectories from birth to 11.5 years: relation to early life food intake. Nutrients. 2012;4(10):1382-98.

33. Garden FL, Marks GB, Almqvist C, Simpson JM, Webb KL. Infant and early childhood dietary predictors of overweight at age 8 years in the CAPS population. European journal of clinical nutrition. 2011;65(4):454-62.

34. Golley, R K, Smithers, L G, Mittinty, M N, et al. Diet quality of U.K. infants is associated with dietary, adiposity, cardiovascular, and cognitive outcomes measured at 7-8 years of age. The Journal of nutrition. 2013;143(10):1611-7.

35. Hertrampf, E, Olivares, M, Pizarro, F, et al. Haemoglobin fortified cereal: a source of available iron to breast-fed infants. European journal of clinical nutrition. 1990;44(11):7938.

36. Iannotti, L L, Zavaleta, N, Leon, Z, et al. Growth and body composition of Peruvian infants in a periurban setting. Food and nutrition bulletin. 2009;30(3):245-53.

37. Kalies, H, Heinrich, J, Borte, $\mathrm{N}$, et al. The effect of breastfeeding on weight gain in infants: results of a birth cohort study. European journal of medical research. 2005;10(1):36-42.

38. Kramer, M S, Guo, T, Platt, R W, et al. Feeding effects on growth during infancy. The Journal of pediatrics. 2004;145(5):600-5. 
39. Morgan, J, Taylor, A, Fewtrell, M. Meat consumption is positively associated with psychomotor outcome in children up to 24 months of age. Journal of pediatric gastroenterology and nutrition. 2004;39(5):493-8.

40. Pan L, Li R, Park S, Galuska DA, Sherry B, Freedman DS. A longitudinal analysis of sugar-sweetened beverage intake in infancy and obesity at 6 years. Pediatrics. 2014;134 Suppl 1:S29-35.

41. Robinson SM, Marriott LD, Crozier SR, Harvey NC, Gale CR, Inskip HM, et al. Variations in infant feeding practice are associated with body composition in childhood: a prospective cohort study. The Journal of clinical endocrinology and metabolism. 2009;94:2799-805.

42. Rose, C M, Savage, J S, Birch, L L. Patterns of early dietary exposures have implications for maternal and child weight outcomes. Obesity (Silver Spring, Md). 2016;24(2):430-8.

43. Santorelli, G, Fairley, L, Petherick, E S, et al. Ethnic differences in infant feeding practices and their relationship with BMI at 3 years of age - results from the Born in Bradford birth cohort study. The British journal of nutrition. 2014;111(10):1891-7.

44. Schack-Nielsen L, Sorensen T, Mortensen EL, Michaelsen KF. Late introduction of complementary feeding, rather than duration of breastfeeding, may protect against adult overweight. The American journal of clinical nutrition. 2010;91:619-27.

45. Sonneville, K R, Long, M W, Rifas S, S L, et al. Juice and water intake in infancy and later beverage intake and adiposity: could juice be a gateway drink? Obesity (Silver Spring, Md). 2015;23(1):170-6.

46. Tantracheewathorn, S. Growth of breast-fed and formula-fed infants compared with national growth references of Thai children. Journal of the Medical Association of Thailand $=$ Chotmaihet thangphaet. 2005;88(2):168-75.

47. Wen, X, Kong, K L, Eiden, R D, et al. Sociodemographic differences and infant dietary patterns. Pediatrics. 2014;134(5):e1387-98.

48. Wosje, K S, Specker, B L, Giddens, J. No differences in growth or body composition from age 12 to 24 months between toddlers consuming $2 \%$ milk and toddlers consuming whole milk. Journal of the American Dietetic Association. 2001;101(1):53-6.

49. Zheng, J S, Liu, H, Zhao, Y M, et al. Complementary feeding and childhood adiposity in preschool-aged children in a large Chinese cohort. The Journal of pediatrics. 2015;166(2):326-31.e2.

\section{Other references}

50. United Nations Development Programme. Human Development Report 2014. Sustaining Human Progress: Reducing Vulnerabilities and Building Resilience. New York; 2014.

51. World Bank. The Little Data Book 2016 Washington, DC2016 [Available from: https://openknowledge.worldbank.org/handle/10986/23968.

\section{ANALYTIC FRAMEWORK}

The analytic framework illustrates the overall scope of the review, including the population, the interventions and/or exposures, comparators, and outcomes of interest. It also includes definitions of key terms and identifies key confounders considered in the systematic review. This is the analytic framework for the systematic reviews conducted to examine the relationship between complementary feeding and growth, size, and body composition. 
Figure 1: Analytic framework

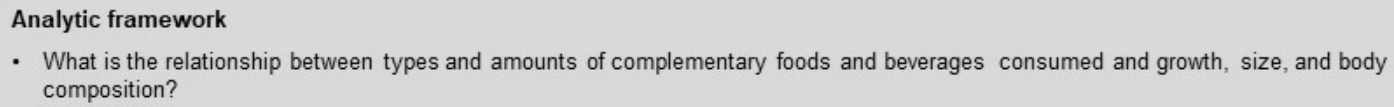

- What is the relationship between types and amounts of complementary foods and beverages consumed and growth, size, and body composition?

\begin{tabular}{|c|c|}
\hline \multicolumn{2}{|l|}{ Target Population } \\
\hline \multicolumn{2}{|c|}{$\begin{array}{l}\text { Generally healthy infants fed human milk, infant formula, or both, } \\
\text { with growth, size, and body composition examined through } \\
\text { adulthood }\end{array}$} \\
\hline & 1 \\
\hline Intervention/Exposure & Comparator \\
\hline $\begin{array}{l}\text { Types and amounts of } \\
\text { complementary foods } \\
\text { and beverages (CFB) } \\
\text { consumed }\end{array}$ & $\begin{array}{l}\text { Different types and amounts } \\
\text { of CFB }\end{array}$ \\
\hline \multicolumn{2}{|l|}{ Health Outcomes } \\
\hline $\begin{array}{l}\text { - Weight and length/heigh } \\
\text { - } \text { BMI, BMI percentile for } \\
\text { - Weight change } \\
\text { - Weight status change } \\
\text { height-for-age, length/s } \\
\text { - Change across more th } \\
\text { length-for-age, weight-fo } \\
\text { circumference for age } \\
\text { - } \% \text { fat mass, \% fat free } \mathrm{m} \\
\text { - Skinfold thickness } \\
\text { - Incidence of healthy wei } \\
\text { Incidence of underweigh } \\
\text { wasting in infants and cl }\end{array}$ & $\begin{array}{l}\text { and z-score } \\
\text { ure-for-age, weight-for-length, } \\
\text { mference for age } \\
\text { one time point of weight-for age, } \\
\text { ength, head, arm, and thigh } \\
\text { ss } \\
\text { t, overweight, obesity } \\
\text { of failure to thrive, stunting, and } \\
\text { dren }\end{array}$ \\
\hline
\end{tabular}

\section{Key Definitions}

Complementary feeding is defined as the process that starts when human milk or infant formula is complemented by other foods and beverages. The complementary feeding period typically continues to 24 months as the young child transitions fully to family foods.

Complementary foods and beverages (CFB) are foods and beverages (liquids, semisolids, and solids) other than human milk or infant formula provided to an infant or young child to provide nutrients and energy.

\begin{tabular}{|c|c|}
\hline Key Confounders & Other Confounders \\
\hline $\begin{array}{l}\text { - Education } \\
\text { - Socioeconomic status } \\
\text { - Sex } \\
\text { - Maternal age } \\
\text { - Race and/or ethnicity } \\
\text { - Milk feeding practices } \\
\text { (breast milk, infant } \\
\text { formula, or both) } \\
\text { - Birth size } \\
\text { - Gestational age }\end{array}$ & 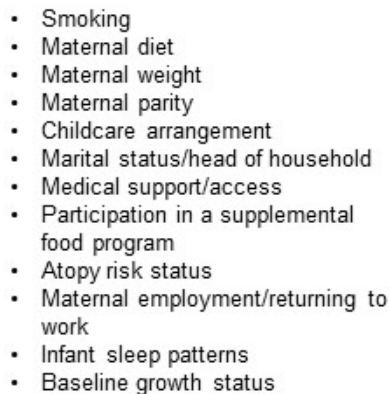 \\
\hline
\end{tabular}

\section{SEARCH PLAN AND RESULTS}

\section{Inclusion and exclusion criteria}

This table provides the inclusion and exclusion criteria for the systematic review question(s) on the types and amounts of CFB consumed and growth, size, and body composition. The inclusion and exclusion criteria are a set of characteristics to determine which studies will be included or excluded in the systematic review. 
Table 7. Inclusion and exclusion criteria

\begin{tabular}{|c|c|c|}
\hline Category & Inclusion Criteria & Exclusion Criteria \\
\hline Study design & $\begin{array}{l}\text { - } \text { Randomized controlled trials } \\
\text { - } \text { Non-randomized controlled trials } \\
\text { - } \text { Prospective cohort studies } \\
\text { - } \quad \text { Case-control studies } \\
\text { - }\end{array}$ & $\begin{array}{l}\text { - } \text { Cross-sectional studies } \\
\text { - Uncontrolled studies } \\
\text { - } \text { Pre/post studies without a control } \\
\text { - } \text { Narrative reviews } \\
\text { - Systematic reviews } \\
\text { - } \text { Meta-analyses }\end{array}$ \\
\hline $\begin{array}{l}\text { Independent } \\
\text { variable } \\
\text { (intervention or } \\
\text { exposure) }\end{array}$ & $\begin{array}{l}\text { Types and amounts of complementary foods } \\
\text { and beverages (CFB) consumed. CFB are } \\
\text { foods and beverages other than human milk } \\
\text { or infant formula (liquids, semisolids, and } \\
\text { solids) provided to an infant or young child to } \\
\text { provide nutrients and energy. }\end{array}$ & $\begin{array}{l}\text { Isolated consumption of human milk, infant } \\
\text { formulas (e.g., milk-based, soy, partially- } \\
\text { hydrolyzed, extensive-hydrolyzed, amino acid- } \\
\text { based), fluid cow's milk before } 12 \text { months of age, } \\
\text { or vitamin and mineral supplements (e.g., iron } \\
\text { drops) }\end{array}$ \\
\hline Comparator & Different types and amounts of CFB & N/A \\
\hline $\begin{array}{l}\text { Dependent } \\
\text { variables } \\
\text { (outcomes) }\end{array}$ & $\begin{array}{l}\text { - Weight and length/height } \\
\text { - } \text { BMI, BMI percentile for age and z-score } \\
\text { - Waist circumference } \\
\text { - Weight change } \\
\text { - Weight status change } \\
\text { - Weight-for-age, length/stature-for-age, weight- } \\
\text { for-length, head, arm, and thigh circumference } \\
\text { for age } \\
\text { - Change across more than one time point of } \\
\text { weight-for age, length-for-age, weight-for- }\end{array}$ & N/A \\
\hline
\end{tabular}




\begin{tabular}{|c|c|c|}
\hline & $\begin{array}{l}\text { length, head, arm, and thigh circumference for } \\
\text { age } \\
\text { - } \% \text { fat mass, \% fat free mass } \\
\text { - Skinfold thickness } \\
\text { - Incidence of healthy weight, overweight, } \\
\text { obesity } \\
\text { - Incidence of underweight or failure to thrive, } \\
\text { stunting, and wasting in infants and children }\end{array}$ & \\
\hline Date range & - January 1980 - July 2016 & \\
\hline Language & - Studies published in English & - Studies published in languages other than English \\
\hline $\begin{array}{l}\text { Publication } \\
\text { status }\end{array}$ & - Studies published in peer-reviewed journals & $\begin{array}{l}\text { Grey literature, including unpublished data, } \\
\text { manuscripts, reports, abstracts, conference } \\
\text { proceedings }\end{array}$ \\
\hline Country $^{1}$ & $\begin{array}{l}\text { - Studies conducted in Very High or High } \\
\text { Human Development Countries }\end{array}$ & $\begin{array}{l}\text { - Studies conducted in Medium or Low Human } \\
\text { Development Countries }\end{array}$ \\
\hline $\begin{array}{l}\text { Study } \\
\text { participants }\end{array}$ & $\begin{array}{l}\text { - Human subjects } \\
\text { - Males } \\
\text { - Females }\end{array}$ & $\begin{array}{l}\text { - Hospitalized patients, not including birth and } \\
\text { immediate post-partum hospitalization of healthy } \\
\text { babies }\end{array}$ \\
\hline $\begin{array}{l}\text { Age of study } \\
\text { participants }\end{array}$ & $\begin{array}{l}\text { - Age at intervention or exposure: } \\
\text { o Infants (0-12 months) } \\
\text { o Toddlers (12-24 months) } \\
\text { - Age at outcome: } \\
\text { o Infants (0-12 months) } \\
\text { o Toddlers (12-24 months) }\end{array}$ & $\begin{array}{l}\text { - Age at intervention or exposure: } \\
\begin{aligned} & \text { o } \text { Child (2-5 years) } \\
& \text { o } \text { Child (6-12 years) } \\
& \text { o } \text { Adolescents (13-18 years) } \\
& \text { o Adults (19 and older) } \\
& \text { o Older adults (65 to } 79 \text { years) }\end{aligned}\end{array}$ \\
\hline
\end{tabular}




\begin{tabular}{|c|c|c|}
\hline & $\begin{array}{ll}\text { o } & \text { Child (2-5 years) } \\
\text { o } & \text { Child (6-12 years) } \\
\text { o } & \text { Adolescents (13-18 years) } \\
\text { o } & \text { Adults (19 and older) } \\
\text { o } & \text { Older adults ( } 65 \text { to } 79 \text { years) } \\
\text { o } & \text { Older adults ( } 80+\text { years) }\end{array}$ & o $\quad$ Older adults (80+ years) \\
\hline $\begin{array}{l}\text { Health status of } \\
\text { study } \\
\text { participants }\end{array}$ & $\begin{array}{l}\text { - Studies done in generally healthy populations } \\
\text { - Studies done in populations where infants } \\
\text { were full term ( } \geq 37 \text { weeks gestational age) } \\
\text { - Studies done in populations with elevated } \\
\text { chronic disease risk, or that enroll some } \\
\text { participants with a disease or with the health } \\
\text { outcome of interest }\end{array}$ & $\begin{array}{l}\text { - Studies that exclusively enroll subjects with a } \\
\text { disease or with the health outcome of interest } \\
\text { - Studies done in hospitalized or malnourished } \\
\text { subjects } \\
\text { - Studies of exclusively pre-term babies (gestational } \\
\text { age }<37 \text { weeks) or babies that are small for } \\
\text { gestational age ( }<2500 \mathrm{~g} \text { ) } \\
\text { - Studies of subjects with infectious diseases (e.g. } \\
\text { HIVIAIDS) (or with mothers diagnosed with an } \\
\text { infectious disease) }\end{array}$ \\
\hline
\end{tabular}

${ }^{1}$ The ratings of country development (e.g., high, medium, low, very low) were based on the Human Development Report 2014 (50). When a country was not included in the Human Development Report 2014 ranking, country classification from the World Bank was used instead (51). Medium Development countries were originally included, but due to concerns about generalizability to the U.S. of study participants (i.e., baseline health status) and complementary foods and beverages typically consumed, a decision was made to exclude "Medium" countries in October 2017 


\section{Search terms and electronic databases used}

\section{PubMed:}

Date(s) Searched: 7/19/2016

Search Terms:

Final:

Complementary OR supplementary OR wean* OR transition* OR introduc* OR "Infant Nutritional Physiological Phenomena"[Mesh:noexp] OR weaning[mesh] OR ((bottle*) NOT (milk OR formula))

AND (feeding* OR food OR beverage*[tiab] OR beverages[mh] OR eating OR $\operatorname{diet[tiab]~OR~diet[mh]~OR~meal*[tiab]~OR~meals[mh]~OR~"Food~and~Beverages"[Mesh]~}$ OR diets[tiab] OR cereal*[tiab] OR "Edible Grain"[Mesh] OR bread*[tiab] OR whole grain* OR juice*[tiab] OR milk[tiab] OR "Milk"[Mesh] OR dairy[tiab] OR "Dairy Products"[Mesh] OR meat[tiab] OR cheese[tiab] OR yogurt[tiab] OR yoghurt*[tiab] OR fruit*[tiab] OR "Fruit"[Mesh] OR vegetable*[tiab] OR "Vegetables"[Mesh] OR egg*[tiab] OR "Eggs"[Mesh] OR nut[tiab] OR nuts[tiab] OR peas[tiab] OR beans[tiab] OR legume*[tiab] OR snack*[tiab] OR bread[mh] OR honey[mh] OR vegetable*[tiab] OR "Vegetables"[Mesh] OR egg*[tiab] OR "Eggs"[Mesh:noexp] OR "egg white"[mh] OR "egg yolk"[mh] OR snack*[tiab] OR candy[mh] OR "Fast Foods"[Mesh] OR meat[mh] OR molasses[mh] OR nuts[mh] OR "Raw Foods"[Mesh] OR seeds[mh])

OR "infant food"[mesh]

OR infant feed*

OR

(breast feeding[mh] OR breastfeeding[tiab] OR breast feeding*[tiab] OR breastfeeding*[tiab] OR breastfed[tiab] OR breast-fed[tiab] OR breast-feed OR breast-feeds)

OR

(Bottle feeding[mh] OR bottle feeding*[tiab]s OR bottle feeding OR bottle-feeding*[tiab] OR bottle-feedings OR bottle-fed[tiab] OR "bottle fed"[tiab])

NOT (editorial[ptyp] OR comment[ptyp] OR news[ptyp] OR letter[ptyp] OR review[ptyp] OR systematic[sb])

OR ((Solid food*) OR solids));

AND

Growth[mh:noexp] OR "Child Development"[Mesh] OR "Growth Charts"[Mesh] OR "growth and development" [Subheading] OR "growth and development"[tiab] OR "Growth and Development"[Mesh:noexp] OR "Growth"[tiab] OR development*[tiab] OR "Child Development"[Mesh] OR child develop*[tiab] OR tooth[mh] OR tooth[tiab] OR teeth[tiab] OR movement[mh] OR "Overnutrition"[Mesh] OR under-nutrition[tiab] OR undernutrition[tiab] OR "developmental delay"[tiab] OR "Motor Skills"[Mesh] OR "Nonverbal Communication"[Mesh] 
Standing[tiab] OR sitting[tiab] OR walking[tiab] OR crawling[tiab] OR "Motor Skills"[Mesh] OR Ages and Stages Questionnaire* OR ASQ[tiab]

OR Cognitive[tiab] OR cognition[mh] OR cognition OR learning OR "Learning Disorders"[Mesh] OR "Intellectual Disability"[Mesh] OR intelligence[tiab] OR intelligence[mh] OR "Achievement"[Mesh] OR "Aptitude"[Mesh] OR "Executive Function"[Mesh] OR memory OR inhibitory control*[tiab] OR "problem solving"[tiab] OR"Social-emotional development"[tiab] OR "Neurological development"[tiab] OR "mental development"[tiab] OR "Motor development"[tiab] OR anxiety[tiab] OR anxiety[mh:noexp] OR "Anxiety, Separation"[Mesh] OR depression[tiab] OR depression[mh] OR "Depression, Postpartum"[Mesh] OR "Depressive Disorder"[Mesh] OR "Visual Acuity"[Mesh] OR "Auditory Perception"[Mesh] OR "Psychological Tests"[Mesh]

OR

("Bone Density"[Mesh] OR "bone density"[tiab] OR "Bone Development"[Mesh] OR "Bone Development"[tiab] OR "Fractures, Bone"[Mesh] OR "Bone Diseases"[Mesh] OR osteoporosis[tiab] OR (bone[tiab] AND fracture*[tiab]) OR "Rickets"[Mesh] OR ricket*[tiab] OR bone mineral*[tiab] OR "bone mass"[tiab] OR bone health*[tiab] OR "Bone Demineralization, Pathologic"[Mesh] OR bone demineral*[tiab])

OR

("body size"[tiab] OR body size[mh] OR obesity[tiab] OR obese[tiab] OR overweight[mh] OR obesity[mh] OR overweight [tiab] OR adipos*[tiab] OR adiposity[mh] OR "body composition"[mh] OR body fat distribution[mh] OR "body fat"[tiab] OR "body weight"[tiab] OR body weight[mh] OR birth weight*[tiab] OR weight gain[mh] OR weight loss[mh] OR "body-weight"[tiab] OR "weight gain"[tiab] OR weightgain[tiab] OR weight loss[tiab] OR weight-loss[tiab] OR "Body Weights and Measures"[mh] OR weight[ti] OR "Anthropometry"[Mesh:noexp] OR body mass index[mh] OR "body mass index"[tiab] OR BMI[tiab] OR "weight status"[tiab] OR "adipose tissue"[mh] OR "healthy weight"[tiab] OR waist circumference[mh] OR "body mass"[ti] OR "fat mass"[tiab] OR body weight changes[mh] OR "waist circumference"[tiab] OR ideal body weight[mh] OR waist-hip ratio[mh] OR Waist Hip*[tiab] OR body height*[tiab] OR Crown-Rump Length*[tiab] OR head circumference*[tiab] OR arm circumference*[tiab] OR thigh circumference* OR limb circumference* OR fat free mass*[tiab] OR skinfold[tiab] OR skin fold*[tiab])

AND

infant* OR baby OR babies OR toddler* OR newborn*[tiab] OR "Child, Preschool"[Mesh] OR preschool*[tiab] OR pre-school*ttiab] OR "early childhood"[tiab] OR "early years"[tiab] OR pre-k[tiab] OR pre-primary[tiab] OR under five*[ti] OR young child*[ti] OR "head start"[tiab] OR prekindergarten[tiab] OR pre-kindergarten[tiab] OR weanling*

OR limit to child, preschool

for child 0-18 all develop outcomes 
for all; body wgt/comp/bone

NOT

nutritional status[mh] OR nutritional status*[tiab] OR Nutrition Status*[tiab] OR Iron[mh] OR iron[tiab] OR "Anemia"[Mesh] OR "Anemia"[tiab] OR iron deficien*[tiab] OR ferritin*[tiab] OR ferrous[tiab] OR "Transferrin"[Mesh] OR "Transferrin"[tiab] OR zinc OR "Vitamin D"[Mesh] OR "Vitamin D"[tiab] OR "Vitamin D Deficiency"[Mesh] OR "Vitamin B 12"[Mesh] OR "Vitamin B 12"[tiab] OR "Vitamin B12"[tiab] OR "Vitamin B 12 Deficiency"[Mesh] OR Cobamide*[tiab] OR Cobalamin*[tiab] OR Cyanocobalamin[tiab] OR Folate[tiab] OR "Folic Acid"[Mesh] OR folacin[tiab] OR vitamin b9*[tiab] OR Fatty acid*[tiab] OR "Fatty Acids"[Mesh:noexp] OR fatty acid*[tiab] OR "Fatty Acids, Unsaturated"[Mesh:noexp] OR Arachidonic acid*[tiab] OR linolenic acid*[tiab] OR linoleic acid*[tiab] OR Docosahexaenoic Acid*[tiab] OR Eicosapentaenoic Acid*[tiab] OR gamma-Linolenic Acid*[tiab] OR "Arachidonic Acids"[Mesh] OR "Fatty Acids, Essential"[Mesh] OR "Fatty Acids, Omega-3"[Mesh] OR "Fatty Acids, Omega-6"[Mesh] OR alpha-Linolenic Acid*[tiab] OR "Fatty Acids, Essential"[Mesh] OR "Linolenic Acids"[Mesh] OR "Trans Fatty Acids"[Mesh] OR "Fatty Acids, Monounsaturated"[Mesh]

for nonmedline[sb]: NOT animals by: NOT (sheep[ti] OR lamb[ti] OR lambs[ti] OR calving[ti] OR calves[ti] OR mice[ti] OR mouse[ti] OR pigs[ti] OR cows[ti] OR piglets[ti] OR cow[ti] OR piglet[ti] OR monkey[ti] OR rats[ti] OR rat[ti] OR animal*[ti])

\section{Embase:}

Date(s) Searched: 8/1/16

Search Terms:

(Complementary OR supplementa* OR wean* OR transition* OR introduc* OR family) NEAR/3 (feed* OR food* OR beverage* OR eating OR diet)

OR

(Complementary OR transition* OR introduct* OR wean*) AND (food/exp OR 'baby food'/exp OR 'cereal'/exp OR 'dairy product'/exp OR 'egg'/exp OR 'fruit'/exp OR 'meat'/exp OR 'sea food'/exp OR 'milk'/exp OR fish/exp OR 'poultry'/exp OR 'beverage'/exp OR 'vegetable'/exp OR nut/exp OR pea/exp OR meal/exp)

OR

(Complementary OR supplementa* OR wean* OR transition* OR introduc*) NEAR/5 ('whole grain' OR 'whole grains' OR dairy OR egg OR eggs OR meat OR poultry OR seafood OR fruit* OR milk OR fish* OR poultry OR beverage* OR vegetables* OR pea OR peas OR nut OR nuts OR cereal OR bread* OR yog*urt* OR cheese* OR juice* OR rice OR soup OR legume* OR snack* OR meal*) (for Embase)

OR 'baby food'/de OR (solid NEAR/2 food*):ab,ti

AND

(infant*:ti,ab OR infant/exp) OR (baby OR babies OR toddler* OR newborn* OR 
nurser*):ti,ab OR 'newborn'/exp OR 'newborn care'/exp OR preschool*:ti,ab OR preschool:ti,ab OR 'preschool child'/exp OR 'infancy'/exp OR "early childhood":ti,ab OR "early years" OR pre-k:ti,ab OR 'nursery'/exp OR 'nursery school'/exp OR prekindergarten:ti,ab OR pre-kindergarten:ti,ab OR weanling*

AND ([in process]/lim OR [article]/lim OR [article in press]/lim) AND ([embase]/lim NOT [medline]/lim)

AND

Limit to humans:

AND

'executive function'/exp OR 'executive function':ti,ab OR 'learning'/exp OR 'intelligence'/exp OR 'mental development'/exp OR 'mental development':ti,ab OR intelligence:ti,ab OR cogniti*:ti,ab OR 'cognition'/exp OR 'cognition assessment'/exp OR aptitude:ti,ab OR 'memory'/exp OR memory:ti,ab OR 'anxiety'/exp OR 'anxiety':ti,ab OR 'depression'/exp OR depressi*:ti,ab OR 'visual acuity'/exp OR visual:ti OR 'hearing'/exp OR hearing:ti,ab OR auditory:ti,ab OR 'postnatal development'/exp OR 'postnatal development':ti,ab OR 'overnutrition'/exp OR 'overnutrition':ti,ab OR undernutrition:ti,ab OR “developmental delay":ti,ab OR 'nonverbal communication'/exp OR

('metabolic bone disease'/exp OR osteoporosis:ti,ab OR (bone NEAR/2 (disease* OR fracture* OR injur* OR health* OR density OR mineralize* OR demineraliz*)):ti,ab OR ricket*:ti,ab OR 'bone injury'/exp OR 'bone density'/exp)

AND

'body size'/de OR 'body size':ti,ab OR 'obesity'/exp OR overweight:ab,ti OR 'macrosomia'/exp OR obese:ab,ti OR obesity:ab,ti OR 'weight gain':ab,ti OR adiposity:ab,ti OR adipose:ab,ti OR 'body weight'/exp OR 'body weight':ti,ab OR 'weight gain'/de OR 'body composition'/exp OR 'body composition':ti,ab OR 'body fat':ab,ti OR 'anthropometry'/de OR 'body mass'/de OR bmi:ab,ti OR 'body mass':ab,ti OR weight:ab,ti OR (waist NEXT/1 hip NEXT/1 ratio*) OR 'body fat'/de OR 'adipose tissue'/exp OR skinfold OR 'skin fold':ti,ab OR 'fat mass':ti,ab OR 'fat mass'/exp OR 'anthropometric parameters'/exp OR circumference OR length OR height

OR

'body growth'/exp 'body growth':ti,ab OR 'growth rate and growth regulation'/exp OR 'postnatal growth'/exp OR 'human development'/exp OR 'Bayley Scales of Infant Development'/exp OR 'cognition assessment'/exp OR 'mental function assessment'/de

Cochrane:

Date(s) Searched: 8/9/16

Search Terms: 
(feed* OR food* OR beverage*OR diet* OR 'whole grain' OR 'whole grains' OR dairy OR egg OR meat OR poultry OR seafood OR fruit* OR milk OR fish* OR poultry OR vegetables* OR pea OR beans OR legume* OR nut OR cereal OR beverage* OR bread* OR seafood OR yog*urt* OR cheese OR juice OR snack OR yogurt OR yoghurt OR nut OR nuts OR honey OR meal OR meals) NEAR/3 (Complementary OR supplementa* OR wean* OR transition* OR introduct* OR family)

\section{OR}

[mh ^^"Infant Nutritional Physiological Phenomena"] OR [mh weaning] OR ((bottle*) NOT (milk OR formula))

AND ([mh beverages] OR [mh eating] OR [mh diet] OR [mh meals] OR [mh "Food and Beverages"] OR [mh "Edible Grain"] OR [mh "Milk"] OR dairy[:ti,ab OR [mh "Dairy Products"] OR [mh "Fruit"] OR [mh "Vegetables"] OR [mh "Eggs"] OR [mh bread] OR [mh honey] OR [mh "Vegetables"] OR [mh^"Eggs"] OR [mh "egg white"] OR [mh "egg yolk"] OR [mh candy] OR [mh "Fast Foods"] OR [mh meat] OR [mh molasses] OR [mh nuts] OR [mh "Raw Foods"] OR [mh seeds])

OR ((Infant* OR baby* OR babies) NEAR/2 food*):ti,ab OR [mh "infant food"]

AND

[mh ^Growth] OR [mh "Child Development"] OR [mh "Growth Charts"] OR "growth and development" OR [mh^"Growth and Development"] OR [mh "Child Development"] OR (child NEAR/1 develop*):ti,ab OR [mh tooth] OR tooth:ti,ab OR teeth:ti,ab OR [mh movement] OR [mh "Overnutrition"] OR "under-nutrition:ti,ab OR undernutrition:ti,ab OR [mh "Motor Skills"] OR [mh "Nonverbal Communication"]

OR

'body growth':ti,ab OR 'growth rate and growth regulation' OR 'postnatal growth':ti,ab OR 'human development':ti,ab OR 'Bayley Scales of Infant Development'

OR Standing:ti,ab OR sitting:ti,ab OR walking:ti,ab OR crawling:ti,ab OR "Ages and Stages Questionnaire" OR ASQ:ti,ab

OR [mh cognition] OR [mh learning] OR [mh "Learning Disorders"] OR [mh "Intellectual Disability"] OR intelligence:ti,ab OR [mh intelligence] OR [mh "Achievement"] OR [mh "Aptitude"] OR [mh "Executive Function"] OR (inhibitory NEAR/1 control*):ti,ab OR "problem solving":ti,ab OR "Social-emotional development":ti,ab OR "Neurological development":ti,ab OR "mental development":ti,ab OR "Motor development"ti,ab OR [mh ^anxiety] OR [mh "Anxiety, Separation"] OR [mh depression] OR [mh "Depression, Postpartum"] OR [mh "Depressive Disorder"] OR [mh "Visual Acuity"] OR [mh "Auditory Perception"] OR [mh "Psychological Tests"]

OR Stunt*:ti,ab OR wasting:ti,ab

OR 
cogniti*:ti,ab OR aptitude:ti,ab OR memory:ti,ab OR [mh memory] OR 'anxiety':ti,ab OR depressi*:ti,ab OR visual:ti,ab OR vision:ti,ab OR hearing:ti,ab OR auditory:ti,ab OR 'postnatal development':ti,ab OR 'overnutrition':ti,ab OR "developmental delay":ti,ab OR 'nonverbal communication'

OR

[mh "Bone Density"] OR [mh "Bone Development"] OR [mh "Fractures, Bone"] OR [mh "Bone Diseases"] OR [mh "Rickets"] OR [mh "Bone Demineralization, Pathologic"] OR osteoporosis:ti,ab OR (bone NEAR/2 (disease* OR fracture* OR injur* OR health* OR density OR mineral* OR demineral* OR develop* OR mass)):ti,ab OR ricket*:ti,ab

OR

'body size':ti,ab OR overweight:ab,ti OR 'macrosomia':ti,ab OR obese:ab,ti OR obesity:ab,ti OR adipos*:ab,ti OR 'body weight':ti,ab OR 'weight gain':ti,ab OR 'body composition':ti,ab OR 'body fat':ab,ti OR 'anthropometr':ti,ab OR bmi:ab,ti OR 'body mass':ab,ti OR (waist NEXT/1 hip NEXT/1 ratio*) OR 'body fat':ti,ab OR 'adipose tissue':ti,ab OR skinfold:ti,ab OR 'skin fold':ti,ab OR 'fat mass':ti, ab OR circumference:ti,ab OR length:ti,ab OR height:ti,ab

([mh "body size"] OR [mh overweight] OR [mh obesity] OR [mh adiposity] OR [mh "body composition"] OR [mh "body fat distribution"] OR [mh "body weight"] OR [mh "weight gain"] OR [mh "weight loss"] OR "weight gain":ti,ab OR "weight loss":ti,ab OR "weight-loss":ti,ab OR [mh "Body Weights and Measures"] OR weight:ti OR [mh ^"Anthropometry"] OR [mh "body mass index"] OR "weight status":ti,ab OR [mh "adipose tissue"] OR "healthy weight":ti,ab OR [mh "waist circumference"] OR [mh "body weight changes"] OR [mh "ideal body weight"] OR [mh "waist-hip ratio"] OR "Waist Hip":ti,ab OR "waist-hip":ti,ab OR "Crown-Rump":ti,ab OR "fat free mass":ti,ab)

NOT (pubmed OR embase)

\section{CINAHL}

Date(s) Searched: 8/22/2016

Search Terms:

(MH "Food and Beverages+") OR (MH "Food") OR (MH "Diet") OR (MH "Eating") OR (MH "Eating Behavior") OR (MH "Taste") OR (MH "Taste Buds") OR (MH "Cereals") OR (MH "Dairy Products") OR (MH "Yogurt") OR (MH "Cheese") OR (MH "Milk") OR (MH "Eggs") OR (MH "Fruit") OR (MH "Fruit Juices") OR (MH "Meat") OR (MH "Seafood") OR (MH "Fish") OR (MH "Poultry") OR (MH "Vegetables") OR (MH "Nuts") OR (MH "Legumes") OR (MH "Bread") AND (Complementary OR supplementa* OR wean* OR transition* OR introduc*)

OR

('whole grain' OR 'whole grains' OR dairy OR egg OR eggs OR meat OR poultry OR seafood OR fruit* OR milk OR fish* OR poultry OR vegetables* OR pea OR peas OR nut OR nuts OR cereal OR beverage* OR bread* OR seafood OR yog*urt* OR 
cheese* OR juice*) N5 (Complementary OR supplementa* OR wean* OR transition* OR introduc* OR family)

OR (Infant* OR baby OR babies) N2 food*

NOT

(MH "Nutritional Status") OR "nutritional status" OR (MH "Nutritional Requirements") OR (MH "Vitamin D") OR (MH "Vitamin D Deficiency") OR (MH "Vitamin B12 Deficiency") OR (MH "Anemia") OR "anemia" OR (MH "Anemia, Iron Deficiency") OR (MH "Iron") OR (MH "Zinc") OR (MH "Vitamin B12") OR (MH "Vitamin B12 Deficiency") OR (MH "Folic Acid") OR (MH "Niacin") OR (MH "Folic Acid Deficiency") OR "folate" OR "folacin" OR cyanocobalamin* OR cobalamin* OR cobamamide* OR (MH "Fatty Acids") OR "fatty acids" OR (MH "Fatty Acids, Omega-6") OR (MH "Fatty Acids, Omega-3") OR (MH "Fatty Acids, Unsaturated") OR (MH "Trans Fatty Acids") OR (MH "Fatty Acids, Monounsaturated") OR (MH "Fatty Acids, Saturated") OR (MH "Fatty Acids, Essential") OR (MH "Arachidonic Acids") OR (MH "Docosahexaenoic Acids") OR (MH "Linolenic Acids") OR (MH "Linoleic Acids")

\section{AND} osteoporosis OR (bone n2 (disease* OR fracture* OR injur* OR health* OR density OR mineralize* OR demineraliz*)) OR ricket* OR (MH "Osteoporosis") OR (MH "Bone Density") OR

(MH "Bone Diseases+") OR (MH "Bone Diseases, Developmental+") OR (MH "Rickets+")

OR

(MH "Executive Function") OR (MH "Learning+") OR (MH "Intelligence+") OR "intelligence" OR (MH "Intelligence Tests") OR (MH "Cognition+") OR "cognition" OR "mental development" OR (MH "Aptitude") OR "aptitude" OR (MH "Aptitude Tests+") OR (MH "Memory+") OR "memory" OR (MH "Anxiety+") OR "anxiety" OR (MH "Depression+") OR "depression" OR (MH "Visual Acuity") OR (MH "Visual Perception+") OR (MH "Hearing+") OR "auditory" OR "overnutrition" OR "undernutrition" OR (MH "Nonverbal Communication+") OR "postnatal development" OR OR "developmental delay"

OR

(MH "Anthropometry+") OR (MH "Body Weights and Measures+") OR (MH "Body Weight+") OR

(MH "Bone Development+") OR (MH "Growth+") OR (MH "Human Development+") OR "bayley scales" OR "mental function" OR (MH "Body Size") OR (MH "Obesity+") OR "overweight" OR "macrosomia" OR (MH "Weight Gain+") OR (MH "Waist-Hip Ratio") OR (MH "Body Composition+") OR (MH "Adipose Tissue+") OR (MH "Abdominal Fat") OR (MH "Fat Free Mass") OR (MH "Body Mass Index") OR (MH "Skinfold Thickness") OR (MH "Head Circumference") OR (MH "Arm Circumference") OR (MH "Waist Circumference") OR (MH "Growth and Development (Omaha)") OR (MH "Body Height") OR (MH "Crown-Rump Length") OR (MH "Leg Length Inequality") OR (MH "Mean Length of Utterance") 
Figure 2: Flow chart of literature search and screening results

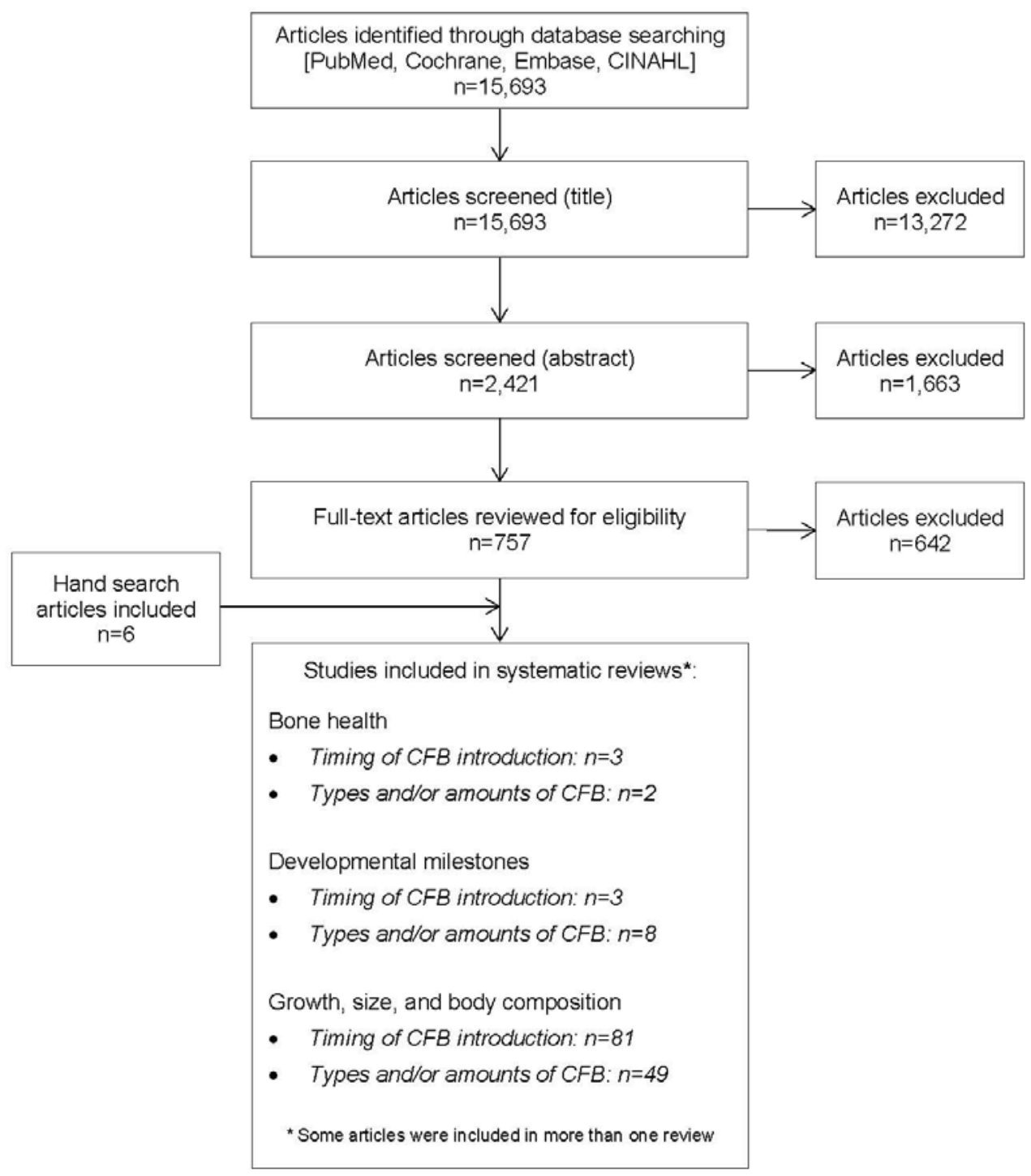

This flow chart illustrates the literature search results for articles examining the relationship between complementary feeding and growth, size, and/or body composition. The results of an electronic database search were screened independently by two NESR analysts by reviewing titles, abstracts, and full text articles to determine which articles met the criteria for inclusion. A manual search was done to ascertain articles not identified through the electronic database search. The systematic review on timing of introduction of CFB included 81 articles, and the systematic review on types and amounts of CFB consumed included 49 articles. The literature search was conducted for multiple systematic reviews that addressed complementary feeding and various health outcomes. 


\section{Excluded articles}

The table below lists the excluded articles with at least one reason for exclusion, but may not reflect all possible reasons.

\section{Table 8. Excluded articles}

\begin{tabular}{|c|c|c|}
\hline & Citation & $\begin{array}{l}\text { Rationale } \\
1\end{array}$ \\
\hline 1 & Complementary feeding in the WHO Multicentre Growth Reference Study. Acta Paediatr Suppl.2006;450:27-37. & DV \\
\hline 2 & $\begin{array}{l}\text { Weaning and the weaning diet. Report of the Working Group on the Weaning Diet of the Committee on Medical Aspects of Food } \\
\text { Policy. Rep Health Soc Subj (Lond).1994;45:1-113. }\end{array}$ & Design \\
\hline 3 & $\begin{array}{l}\text { Aarts, C.,Kylberg, E.,Hofvander, Y.,Gebre-Medhin, M. Growth under privileged conditions of healthy Swedish infants exclusively } \\
\text { breastfed from birth to 4-6 months: a longitudinal prospective study based on daily records of feeding. Acta } \\
\text { Paediatr.2003;92:145-51. }\end{array}$ & IV \\
\hline 4 & $\begin{array}{l}\text { Abarin, T.,Yan Wu, Y.,Warrington, N.,Lye, S.,Pennell, C.,Briollais, L. The impact of breastfeeding on FTO-related BMI growth } \\
\text { trajectories: an application to the Raine pregnancy cohort study. Int J Epidemiol.2012;41:1650-60. }\end{array}$ & IV \\
\hline 5 & $\begin{array}{l}\text { Abou Samra, H.,Stevens, D.,Binkley, T.,Specker, B. Determinants of bone mass and size in 7-year-old former term, late-preterm, } \\
\text { and preterm boys. Osteoporos Int.2009;20:1903-10. }\end{array}$ & Design, IV \\
\hline 6 & $\begin{array}{l}\text { Aboud, F. E.,Akhter, S. A cluster-randomized evaluation of a responsive stimulation and feeding intervention in bangladesh. } \\
\text { Pediatrics.2011;127:e1191-7. }\end{array}$ & IV \\
\hline 7 & $\begin{array}{l}\text { Aboud, F. E.,Shafique, S.,Akhter, S. A responsive feeding intervention increases children's self-feeding and maternal } \\
\text { responsiveness but not weight gain. J Nutr.2009;139:1738-43. }\end{array}$ & IV \\
\hline 8 & $\begin{array}{l}\text { Adu-Afarwuah, S.,Lartey, A.,Brown, K. H.,Zlotkin, S.,Briend, A.,Dewey, K. G. Randomized comparison of } 3 \text { types of micronutrient } \\
\text { supplements for home fortification of complementary foods in Ghana: effects on growth and motor development. Am J Clin } \\
\text { Nutr.2007;86:412-20. }\end{array}$ & IV \\
\hline 9 & $\begin{array}{l}\text { Agarwal, K. N.,Agarwal, D. K.,Gupta, A.,Bansal, A. K. Relationship of exclusive breast feeding for } 6 \text { mo to linear growth up to } 18 \\
\text { mo of age. Indian J Pediatr.2013;80:11-5. }\end{array}$ & Country \\
\hline 10 & $\begin{array}{l}\text { Aggarwal, A.,Arora, S.,Patwari, A. K. Breastfeeding among urban women of low-socioeconomic status: factors influencing } \\
\text { introduction of supplemental feeds before four months of age. Indian Pediatr.1998;35:269-73. }\end{array}$ & $\begin{array}{l}\text { Design, } \\
\text { IV,DV }\end{array}$ \\
\hline 11 & $\begin{array}{l}\text { Agostoni, C.,Fiocchi, A.,Riva, E.,Terracciano, L.,Sarratud, T.,Martelli, A.,Lodi, F.,D'Auria, E.,Zuccotti, G.,Giovannini, M. Growth of } \\
\text { infants with IgE-mediated cow's milk allergy fed different formulas in the complementary feeding period. Pediatr Allergy } \\
\text { Immunol.2007;18:599-606. }\end{array}$ & IV \\
\hline 12 & $\begin{array}{l}\text { Agostoni, C.,Grandi, F.,Gianni, M. L.,Silano, M.,Torcoletti, M.,Giovannini, M.,Riva, E. Growth patterns of breast fed and formula } \\
\text { fed infants in the first } 12 \text { months of life: an Italian study. Arch Dis Child.1999;81:395-9. }\end{array}$ & IV \\
\hline
\end{tabular}




\begin{tabular}{|c|c|c|}
\hline 13 & $\begin{array}{l}\text { Agostoni, C.,Grandi, F.,Scaglioni, S.,Gianni, M. L.,Torcoletti, M.,Radaelli, G.,Fiocchi, A.,Riva, E. Growth pattern of breastfed and } \\
\text { nonbreastfed infants with atopic dermatitis in the first year of life. Pediatrics.2000;106:E73. }\end{array}$ & IV \\
\hline 14 & $\begin{array}{l}\text { Agostoni,C.,Marangoni,F.,Lammardo,A. M.,Giovannini,M.,Riva,E.,Galli,C. Breastfeeding duration, milk fat composition and } \\
\text { developmental indices at } 1 \text { year of life among breastfed infants. Prostaglandins Leukot Essent Fatty Acids.2001;64:105-9. }\end{array}$ & IV \\
\hline 15 & $\begin{array}{l}\text { Agostoni,C.,Zuccotti,G. V.,Radaelli,G.,Besana,R.,Podesta,A.,Sterpa,A.,Rottoli,A.,Riva,E.,Giovannini,M. Docosahexaenoic acid } \\
\text { supplementation and time at achievement of gross motor milestones in healthy infants: a randomized, prospective, double-blind, } \\
\text { placebo-controlled trial. Am J Clin Nutr.2009;89:64-70. }\end{array}$ & IV \\
\hline 16 & $\begin{array}{l}\text { Allen, L.,Shrimpton, R. The International Research on Infant Supplementation study: implications for programs and further } \\
\text { research. J Nutr.2005;135:666s-669s. }\end{array}$ & Design \\
\hline 17 & $\begin{array}{l}\text { Alm,B.,Aberg,N.,Erdes,L.,Mollborg,P.,Pettersson,R.,Norvenius,S. G.,Goksor,E.,Wennergren,G. Early introduction of fish } \\
\text { decreases the risk of eczema in infants. Arch Dis Child.2009;94:11-5. }\end{array}$ & DV \\
\hline 18 & $\begin{array}{l}\text { Almqvist,C.,Garden,F.,Xuan,W.,Mihrshahi,S.,Leeder,S. R.,Oddy,W.,Webb,K.,Marks,G. B. Omega-3 and omega-6 fatty acid } \\
\text { exposure from early life does not affect atopy and asthma at age } 5 \text { years. J Allergy Clin Immunol.2007;119:1438-44. }\end{array}$ & IV, DV \\
\hline 19 & $\begin{array}{l}\text { Alvarez-Uria, G.,Midde, M.,Pakam, R.,Bachu, L.,Naik, P. K. Effect of Formula Feeding and Breastfeeding on Child Growth, Infant } \\
\text { Mortality, and HIV Transmission in Children Born to HIV-Infected Pregnant Women Who Received Triple Antiretroviral Therapy in } \\
\text { a Resource-Limited Setting: Data from an HIV Cohort Study in India. ISRN Pediatr.2012;2012:763591. }\end{array}$ & $\begin{array}{l}\text { Health } \\
\text { statu }\end{array}$ \\
\hline 20 & $\begin{array}{l}\text { Andersen, L. B.,Molgaard, C.,Michaelsen, K. F.,Carlsen, E. M.,Bro, R.,Pipper, C. B. Indicators of dietary patterns in Danish } \\
\text { infants at } 9 \text { months of age. Food Nutr Res.2015;59:27665. }\end{array}$ & Design \\
\hline 21 & $\begin{array}{l}\text { Andersen,A. D.,Michaelsen,K. F.,Hellgren,L. I.,Trolle,E.,Lauritzen,L. A randomized controlled intervention with fish oil versus } \\
\text { sunflower oil from } 9 \text { to } 18 \text { months of age: exploring changes in growth and skinfold thicknesses. Pediatr Res.2011;70:368-74. }\end{array}$ & IV \\
\hline 22 & $\begin{array}{l}\text { Andersen,L. B.,Pipper,C. B.,Trolle,E.,Bro,R.,Larnkjaer,A.,Carlsen,E. M.,Molgaard,C.,Michaelsen,K. F. Maternal obesity and } \\
\text { offspring dietary patterns at } 9 \text { months of age. Eur J Clin Nutr.2015;69:668-75. }\end{array}$ & DV \\
\hline 23 & $\begin{array}{l}\text { Anderson, G. H.,Morson-Pasut, L. A.,Bryan, H.,Cleghorn, G.,Tanaka, P.,Yeung, D.,Zimmerman, B. Age of introduction of cow's } \\
\text { milk to infants. J Pediatr Gastroenterol Nutr.1985;4:692-8. }\end{array}$ & Design \\
\hline 24 & $\begin{array}{l}\text { Anderson, V. P.,Cornwall, J.,Jack, S.,Gibson, R. S. Intakes from non-breastmilk foods for stunted toddlers living in poor urban } \\
\text { villages of Phnom Penh, Cambodia, are inadequate. Matern Child Nutr.2008;4:146-59. }\end{array}$ & $\begin{array}{l}\text { Design,He } \\
\text { alth status }\end{array}$ \\
\hline 25 & $\begin{array}{l}\text { Andres, A.,Casey, P. H.,Cleves, M. A.,Badger, T. M. Body fat and bone mineral content of infants fed breast milk, cow's milk } \\
\text { formula, or soy formula during the first year of life. J Pediatr.2013;163:49-54. }\end{array}$ & IV \\
\hline 26 & $\begin{array}{l}\text { Andres, A.,Cleves, M. A.,Bellando, J. B.,Pivik, R. T.,Casey, P. H.,Badger, T. M. Developmental status of 1-year-old infants fed } \\
\text { breast milk, cow's milk formula, or soy formula. Pediatrics.2012;129:1134-40. }\end{array}$ & IV \\
\hline 27 & $\begin{array}{l}\text { Andrissi, L.,Mottini, G.,Sebastiani, V.,Boldrini, L.,Giuliani, A. Dietary habits and growth: an urban/rural comparison in the Andean } \\
\text { region of Apurimac, Peru. Ann Ist Super Sanita.2013;49:340-6. }\end{array}$ & IV \\
\hline 28 & Anfield,L. Nutrition in the first year. Midwife Health Visit Community Nurse.1985;21:161-4. & Design \\
\hline
\end{tabular}




\begin{tabular}{|c|c|c|}
\hline 29 & $\begin{array}{l}\text { Anzman-Frasca, S.,Liu, S.,Gates, K. M.,Paul, I. M.,Rovine, M. J.,Birch, L. L. Infants' Transitions out of a Fussing/Crying State Are } \\
\text { Modifiable and Are Related to Weight Status. Infancy.2013;18:662-686. }\end{array}$ & IV \\
\hline 30 & Armstrong, J.,Reilly, J. J. Breastfeeding and lowering the risk of childhood obesity. Lancet.2002;359:2003-4. & IV \\
\hline 31 & $\begin{array}{l}\text { Arsenault,J. E.,Havel,P. J.,Lopez de Romana,D.,Penny,M. E.,Van Loan,M. D.,Brown,K. H. Longitudinal measures of circulating } \\
\text { leptin and ghrelin concentrations are associated with the growth of young Peruvian children but are not affected by zinc } \\
\text { supplementation. Am J Clin Nutr.2007;86:1111-9. }\end{array}$ & $\begin{array}{l}\text { Health } \\
\text { status }\end{array}$ \\
\hline 32 & Arvas, A.,Elgormus, Y.,Gur, E.,Alikasifoglu, M.,Celebi, A. Iron status in breast-fed full-term infants. Turk J Pediatr.2000;42:22-6. & IV \\
\hline 33 & $\begin{array}{l}\text { Asha Bai, P. V.,Leela, M.,Subramaniam, V. R. Adequacy of breast milk for optimal growth of infants. Trop Geogr } \\
\text { Med.1980;32:158-62. }\end{array}$ & IV \\
\hline 34 & $\begin{array}{l}\text { Assuncao, M. L.,Ferreira, H. S.,Coutinho, S. B.,Santos, L. M.,Horta, B. L. Protective effect of breastfeeding against overweight } \\
\text { can be detected as early as the second year of life: a study of children from one of the most socially-deprived areas of Brazil. J } \\
\text { Health Popul Nutr.2015;33:85-91. }\end{array}$ & $\begin{array}{l}\text { Design, } \\
\text { Health } \\
\text { status, IV }\end{array}$ \\
\hline 35 & $\begin{array}{l}\text { Atladottir, H., Thorsdottir, I. Energy intake and growth of infants in Iceland-a population with high frequency of breast-feeding and } \\
\text { high birth weight. Eur J Clin Nutr.2000;54:695-701. }\end{array}$ & IV \\
\hline 36 & Auestad,N. Infant nutrition--brain development--disease in later life. An introduction. Dev Neurosci.2000;22:472-3. & Design \\
\hline 37 & $\begin{array}{l}\text { Augusto,R. A.,Souza,J. M. Effectiveness of a supplementary feeding program in child weight gain. Rev Saude } \\
\text { Publica.2010;44:793-801. }\end{array}$ & Design, IV \\
\hline 38 & $\begin{array}{l}\text { Axelsson,I. E.,Jakobsson,I.,Raiha,N. C. Formula with reduced protein content: effects on growth and protein metabolism during } \\
\text { weaning. Pediatr Res.1988;24:297-301. }\end{array}$ & IV \\
\hline 39 & $\begin{array}{l}\text { Azad, M. B.,Konya, T.,Maughan, H.,Guttman, D. S.,Field, C. J.,Chari, R. S.,Sears, M. R.,Becker, A. B.,Scott, J. A.,Kozyrskyj, A. } \\
\text { L. Gut microbiota of healthy Canadian infants: profiles by mode of delivery and infant diet at } 4 \text { months. Cmaj.2013;185:385-94. }\end{array}$ & DV \\
\hline 40 & Badger, T. Effects of soy infant formula on growth and development in the first year of life. Food Nutr Bull.2013;34:252-3. & Design, IV \\
\hline 41 & $\begin{array}{l}\text { Bahamondes L,Bahamondes MV,Modesto W,Tilley IB,Magalhaes A,Pinto e Silva JL,Amaral E, Jr. Mishell DR. Effect of hormonal } \\
\text { contraceptives during breastfeeding on infant's milk ingestion and growth. Fertil Steril.2013;100:445-50. }\end{array}$ & IV \\
\hline 42 & $\begin{array}{l}\text { Bai, K. I.,Sastry, V. N.,Reddy, C. C. A comparative study of feeding pattern of infants in rural and urban areas. Indian J } \\
\text { Pediatr.1981;48:277-80. }\end{array}$ & Design, IV \\
\hline 43 & $\begin{array}{l}\text { Balaban, G., Motta, M. E.,Silva, G. A. Early weaning and other potential risk factors for overweight among preschool children. } \\
\text { Clinics (Sao Paulo).2010;65:181-7. }\end{array}$ & IV, Age \\
\hline 44 & $\begin{array}{l}\text { Balogun,T. A.,Lombard,M. J.,McLachlan,M. The nutrient intake of children aged 12-36 months living in two communities in the } \\
\text { Breede Valley, Western Cape province, South Africa. South African Family Practice.2015;57:1-7 7p. }\end{array}$ & Design \\
\hline 45 & $\begin{array}{l}\text { Baranowski, T.,Bryan, G. T.,Harrison, J. A.,Rassin, D. K.,Greaves, K. A.,Baranowski, J. H. Height, infant-feeding practices and } \\
\text { cardiovascular functioning among } 3 \text { or } 4 \text { year old children in three ethnic groups. J Clin Epidemiol.1992;45:513-8. }\end{array}$ & DV \\
\hline
\end{tabular}




\begin{tabular}{|c|c|c|}
\hline 46 & $\begin{array}{l}\text { Bartok, C. J.,Schaefer, E. W.,Beiler, J. S.,Paul, I. M. Role of body mass index and gestational weight gain in breastfeeding } \\
\text { outcomes. Breastfeed Med.2012;7:448-56. }\end{array}$ & IV, DV \\
\hline 47 & Beal, V. A. Nutrition and growth-patterns of young children. ASDC J Dent Child.1983;50:139-41. & Design \\
\hline 48 & $\begin{array}{l}\text { Begum, H. A.,Mascie-Taylor, C.,Nahar, S. The impact of food supplementation on infant weight gain in rural Bangladesh; an } \\
\text { assessment of the Bangladesh Integrated Nutritional Program (BINP). Public Health Nutr.2007;10:49-54. }\end{array}$ & IV \\
\hline 49 & $\begin{array}{l}\text { Beinner,M. A.,Velasquez-Melendez,G.,Pessoa,M. C.,Greiner,T. Iron-fortified rice is as efficacious as supplemental iron drops in } \\
\text { infants and young children. J Nutr.2010;140:49-53. }\end{array}$ & IV, DV \\
\hline 50 & $\begin{array}{l}\text { Ben,X. M.,Zhou,X. Y.,Zhao,W. H.,Yu,W. L.,Pan,W.,Zhang,W. L.,Wu,S. M.,Van Beusekom,C. M.,Schaafsma,A. Growth and } \\
\text { development of term infants fed with milk with long-chain polyunsaturated fatty acid supplementation. Chin Med J } \\
\text { (Engl).2004;117:1268-70. }\end{array}$ & IV \\
\hline 51 & $\begin{array}{l}\text { Bennett,W. E.,Jr.,Hendrix,K. S.,Thompson-Fleming,R. T.,Downs,S. M.,Carroll,A. E. Early cow's milk introduction is associated } \\
\text { with failed personal-social milestones after } 1 \text { year of age. Eur J Pediatr.2014;173:887-92. }\end{array}$ & IV \\
\hline 52 & $\begin{array}{l}\text { Bergmann, K. E.,Bergmann, R. L.,Von Kries, R.,Bohm, O.,Richter, R.,Dudenhausen, J. W.,Wahn, U. Early determinants of } \\
\text { childhood overweight and adiposity in a birth cohort study: role of breast-feeding. Int J Obes Relat Metab Disord.2003;27:162-72. }\end{array}$ & IV \\
\hline 53 & $\begin{array}{l}\text { Bernal, M. J.,Periago, M. J.,Martinez, R.,Ortuno, I.,Sanchez-Solis, M.,Ros, G.,Romero, F.,Abellan, P. Effects of infant cereals with } \\
\text { different carbohydrate profiles on colonic function--randomised and double-blind clinical trial in infants aged between } 6 \text { and } 12 \\
\text { months--pilot study. Eur J Pediatr.2013;172:1535-42. }\end{array}$ & IV \\
\hline 54 & $\begin{array}{l}\text { Berni Canani R,Nocerino R,Terrin G,Frediani T,Lucarelli S,Cosenza L,Passariello A,Leone L,Granata V,Di Costanzo M,Pezzella } \\
\text { V,Troncone R. Formula selection for management of children with cow's milk allergy influences the rate of acquisition of } \\
\text { tolerance: a prospective multicenter study. J Pediatr.2013;163:771-7.e1. }\end{array}$ & IV, DV \\
\hline 55 & $\begin{array}{l}\text { Betoko, A.,Charles, M. A.,Hankard, R.,Forhan, A.,Bonet, M.,Regnault, N.,Botton, J.,Saurel-Cubizolles, M. J.,de Lauzon-Guillain, } \\
\text { B. Determinants of infant formula use and relation with growth in the first } 4 \text { months. Matern Child Nutr.2014;10:267-79. }\end{array}$ & IV \\
\hline 56 & $\begin{array}{l}\text { Betoko, A.,Charles, M. A.,Hankard, R.,Forhan, A.,Bonet, M.,Saurel-Cubizolles, M. J.,Heude, B.,de Lauzon-Guillain, B. Infant } \\
\text { feeding patterns over the first year of life: influence of family characteristics. Eur J Clin Nutr.2013;67:631-7. }\end{array}$ & DV \\
\hline 57 & $\begin{array}{l}\text { Bhandari, N.,Bahl, R.,Nayyar, B.,Khokhar, P.,Rohde, J. E.,Bhan, M. K. Food supplementation with encouragement to feed it to } \\
\text { infants from } 4 \text { to } 12 \text { months of age has a small impact on weight gain. J Nutr.2001;131:1946-51. }\end{array}$ & Country \\
\hline 58 & $\begin{array}{l}\text { Bhandari, N.,Mazumder, S.,Bahl, R.,Martines, J.,Black, R. E.,Bhan, M. K. An educational intervention to promote appropriate } \\
\text { complementary feeding practices and physical growth in infants and young children in rural Haryana, India. J } \\
\text { Nutr.2004;134:2342-8. }\end{array}$ & IV \\
\hline 59 & $\begin{array}{l}\text { Bhatia, B. D.,Banerjee, D.,Agarwal, D. K.,Agarwal, K. N. Exterogestate growth: relationship with maternal body size and dietary } \\
\text { intakes. Indian J Pediatr.1983;50:241-6. }\end{array}$ & $\begin{array}{l}\text { Health } \\
\text { status, IV }\end{array}$ \\
\hline 60 & $\begin{array}{l}\text { Bindon, J. R.,Cabrera, C. Infant feeding patterns and growth of infants in American Samoa during the first year of life. Hum } \\
\text { Biol.1988;60:81-92. }\end{array}$ & $\begin{array}{l}\text { Design, IV, } \\
\text { DV }\end{array}$ \\
\hline
\end{tabular}




\begin{tabular}{|c|c|c|}
\hline 61 & $\begin{array}{l}\text { Bindon, J. R. The body build and composition of Samoan children: relationships to infant feeding patterns and infant weight-for- } \\
\text { length status. Am J Phys Anthropol.1984;63:379-88. }\end{array}$ & IV \\
\hline 62 & Bindon, J. R. The influence of infant feeding patterns on growth of children in American Samoa. Med Anthropol.1985;9:183-95. & Country \\
\hline 63 & $\begin{array}{l}\text { Birch,E. E.,Garfield,S.,Castaneda,Y.,Hughbanks-Wheaton,D.,Uauy,R.,Hoffman,D. Visual acuity and cognitive outcomes at } 4 \\
\text { years of age in a double-blind, randomized trial of long-chain polyunsaturated fatty acid-supplemented infant formula. Early Hum } \\
\text { Dev.2007;83:279-84. }\end{array}$ & IV \\
\hline 64 & $\begin{array}{l}\text { Bisimwa, G.,Owino, V. O.,Bahwere, P.,Dramaix, M.,Donnen, P.,Dibari, F.,Collins, S. Randomized controlled trial of the } \\
\text { effectiveness of a soybean-maize-sorghum-based ready-to-use complementary food paste on infant growth in South Kivu, } \\
\text { Democratic Republic of Congo. Am J Clin Nutr.2012;95:1157-64. }\end{array}$ & IV \\
\hline 65 & $\begin{array}{l}\text { Bjorke-Monsen, A. L. Is exclusive breastfeeding ensuring an optimal micronutrient status and psychomotor development in } \\
\text { infants?. Clin Biochem.2014;47:714. }\end{array}$ & Design \\
\hline 66 & Block,S. L. Delayed introduction of solid foods to infants: not so fast!. Pediatr Ann.2013;42:143-7. & Design \\
\hline 67 & $\begin{array}{l}\text { Bogen, D. L.,Hanusa, B. H.,Whitaker, R. C. The effect of breast-feeding with and without formula use on the risk of obesity at } 4 \\
\text { years of age. Obes Res.2004;12:1527-35. }\end{array}$ & IV \\
\hline 68 & $\begin{array}{l}\text { Bonuck, K.,Avraham, S. B.,Lo, Y.,Kahn, R.,Hyden, C. Bottle-weaning intervention and toddler overweight. J } \\
\text { Pediatr.2014;164:306-12.e1-2. }\end{array}$ & IV \\
\hline 69 & $\begin{array}{l}\text { Borschel, M. W.,Baggs, G. E.,Barrett-Reis, B. Growth of healthy term infants fed ready-to-feed and powdered forms of an } \\
\text { extensively hydrolyzed casein-based infant formula: a randomized, blinded, controlled trial. Clin Pediatr (Phila).2014;53:585-92. }\end{array}$ & IV \\
\hline 70 & $\begin{array}{l}\text { Boulton J. Nutrition in childhood and its relationships to early somatic growth, body fat, blood pressure, and physical fitness. Acta } \\
\text { Paediatr Scand Suppl.1981;284:1-85. }\end{array}$ & Design,DV \\
\hline 71 & $\begin{array}{l}\text { Brakohiapa, L. A.,Yartey, J.,Bille, A.,Harrison, E.,Quansah, E.,Armar, M. A., Kishi, K.,Yamamoto, S. Does prolonged } \\
\text { breastfeeding adversely affect a child's nutritional status?. Lancet.1988;2:416-8. }\end{array}$ & IV, DV \\
\hline 72 & $\begin{array}{l}\text { Brazionis, L., Golley, R. K.,Mittinty, M. N.,Smithers, L. G.,Emmett, P.,Northstone, K.,Lynch, J. W. Diet spanning infancy and } \\
\text { toddlerhood is associated with child blood pressure at age } 7.5 \text { y. Am J Clin Nutr.2013;97:1375-86. }\end{array}$ & DV \\
\hline 73 & $\begin{array}{l}\text { Breij, L. M.,Mulder, M. T.,van Vark-van der Zee, L. C.,Hokken-Koelega, A. C. Appetite-regulating hormones in early life and } \\
\text { relationships with type of feeding and body composition in healthy term infants. Eur J Nutr.2016. }\end{array}$ & IV \\
\hline 74 & $\begin{array}{l}\text { Brekke, H. K.,van Odijk, J.,Ludvigsson, J. Predictors and dietary consequences of frequent intake of high-sugar, low-nutrient } \\
\text { foods in 1-year-old children participating in the ABIS study. Br J Nutr.2007;97:176-81. }\end{array}$ & DV \\
\hline 75 & $\begin{array}{l}\text { Brew,B. K.,Toelle,B. G.,Webb,K. L.,Almqvist,C.,Marks,G. B. Omega-3 supplementation during the first } 5 \text { years of life and later } \\
\text { academic performance: a randomised controlled trial. Eur J Clin Nutr.2015;69:419-24. }\end{array}$ & IV \\
\hline 76 & $\begin{array}{l}\text { Briend,A.,Bari,A. Breastfeeding improves survival, but not nutritional status, of 12-35 months old children in rural Bangladesh. } \\
\text { Eur J Clin Nutr.1989;43:603-8. }\end{array}$ & $\begin{array}{l}\text { Health } \\
\text { status, IV }\end{array}$ \\
\hline
\end{tabular}




\begin{tabular}{|c|c|c|}
\hline 77 & $\begin{array}{l}\text { Briend,A.,Darmon,N. Determining limiting nutrients by linear programming: A new approach to predict insufficient intakes from } \\
\text { complementary foods. Pediatrics.2000;106:1288-9. }\end{array}$ & Design \\
\hline 78 & $\begin{array}{l}\text { Brito,A.,Olivares,M.,Pizarro,T.,Rodriguez,L.,Hertrampf,E. Chilean complementary feeding program reduces anemia and improves } \\
\text { iron status in children aged } 11 \text { to } 18 \text { months. Food Nutr Bull.2013;34:378-85. }\end{array}$ & Design \\
\hline 79 & Brown A,Lee MD. Early influences on child satiety-responsiveness: the role of weaning style. Pediatr Obes.2015;10:57-66. & IV \\
\hline 80 & $\begin{array}{l}\text { Brown, A.,Lee, M. Breastfeeding during the first year promotes satiety responsiveness in children aged 18-24 months. Pediatr } \\
\text { Obes.2012;7:382-90. }\end{array}$ & IV \\
\hline 81 & $\begin{array}{l}\text { Brown,K. H.,Lopez de Romana,D.,Arsenault,J. E.,Peerson,J. M.,Penny,M. E. Comparison of the effects of zinc delivered in a } \\
\text { fortified food or a liquid supplement on the growth, morbidity, and plasma zinc concentrations of young Peruvian children. Am J } \\
\text { Clin Nutr.2007;85:538-47. }\end{array}$ & IV \\
\hline 82 & $\begin{array}{l}\text { Brown,L. V.,Zeitlin,M. F.,Peterson,K. E.,Chowdhury,A. M.,Rogers,B. L.,Weld,L. H.,Gershoff,S. N. Evaluation of the impact of } \\
\text { weaning food messages on infant feeding practices and child growth in rural Bangladesh. Am J Clin Nutr.1992;56:994-1003. }\end{array}$ & IV \\
\hline 83 & $\begin{array}{l}\text { Brulotte, J.,Bukutu, C.,Vohra, S. Complementary, holistic, and integrative medicine: fish oils and neurodevelopmental disorders. } \\
\text { Pediatr Rev.2009;30:e29-33. }\end{array}$ & Design \\
\hline 84 & $\begin{array}{l}\text { Bulk-Bunschoten, A. M.,van Bodegom, S.,Reerink, J. D.,de Jong, P. C.,de Groot, C. J. Weight and weight gain at } 4 \text { months (The } \\
\text { Netherlands 1998): influences of nutritional practices, socio-economic and ethnic factors. Paediatr Perinat } \\
\text { Epidemiol.2002;16:361-9. }\end{array}$ & IV \\
\hline 85 & $\begin{array}{l}\text { Burnham, L.,Matlak, S.,Makrigiorgos, G.,Braun, N.,Knapp, B. P.,Merewood, A. Breastfeeding and coffee consumption in children } \\
\text { younger than } 2 \text { years in Boston, Massachusetts, USA. J Hum Lact.2015;31:267-72. }\end{array}$ & DV \\
\hline 86 & $\begin{array}{l}\text { Caleyachetty A,Krishnaveni GV,Veena SR,Hill J,Karat SC,Fall CH,Wills AK. Breastfeeding duration, age of starting solids and } \\
\text { high BMI risk and adiposity in Indian children. Matern Child Nutr.2013;9:199-216. }\end{array}$ & $\begin{array}{l}\text { Design,Co } \\
\text { untry }\end{array}$ \\
\hline 87 & Calvo,E. B.,Galindo,A. C.,Aspres,N. B. Iron status in exclusively breast-fed infants. Pediatrics.1992;90:375-9. & IV, DV \\
\hline 88 & $\begin{array}{l}\text { Calvo,E.,Hertrampf,E.,Pablo,S.,Amar,M.,Stekel,A. Haemoglobin-fortified cereal: an alternative weaning food with high iron } \\
\text { bioavailability. European journal of clinical nutrition.1989;43:237-43. }\end{array}$ & $\begin{array}{l}\text { Design, } \\
\text { DV }\end{array}$ \\
\hline 89 & $\begin{array}{l}\text { Cameron, S. L.,Heath, A. L.,Gray, A. R., Churcher, B.,Davies, R. S.,Newlands, A., Galland, B. C.,Sayers, R. M.,Lawrence, J. } \\
\text { A.,Taylor, B. J.,Taylor, R. W. Lactation Consultant Support from Late Pregnancy with an Educational Intervention at } 4 \text { Months of } \\
\text { Age Delays the Introduction of Complementary Foods in a Randomized Controlled Trial. J Nutr.2015;145:1481-90. }\end{array}$ & DV \\
\hline 90 & $\begin{array}{l}\text { Capozzi,L.,Russo,R.,Bertocco,F.,Ferrara,D.,Ferrara,M. Diet and iron deficiency in the first year of life: a retrospective study. } \\
\text { Hematology.2010;15:410-3. }\end{array}$ & DV \\
\hline 91 & $\begin{array}{l}\text { Capozzi,L.,Russo,R.,Bertocco,F.,Ferrara,D.,Ferrara,M. Effect on haematological and anthropometric parameters of iron } \\
\text { supplementation in the first } 2 \text { years of life. Risks and benefits. Hematology.2011;16:261-4. }\end{array}$ & IV \\
\hline 92 & $\begin{array}{l}\text { Carruth,B. R.,Nevling,W.,Skinner,J. D. Developmental and food profiles of infants born to adolescent and adult mothers. J } \\
\text { Adolesc Health.1997;20:434-41. }\end{array}$ & $\begin{array}{l}\text { IV, DV, } \\
\text { Age }\end{array}$ \\
\hline
\end{tabular}




\begin{tabular}{|c|c|c|}
\hline 93 & $\begin{array}{l}\text { Casiday, R. E.,Wright, C. M.,Panter-Brick, C.,Parkinson, K. N. Do early infant feeding patterns relate to breast-feeding } \\
\text { continuation and weight gain? Data from a longitudinal cohort study. Eur J Clin Nutr.2004;58:1290-6. }\end{array}$ & IV \\
\hline 94 & $\begin{array}{l}\text { Castillo-Duran,C.,Perales,C. G.,Hertrampf,E. D.,Marin,V. B.,Rivera,F. A., Icaza,G. Effect of zinc supplementation on development } \\
\text { and growth of Chilean infants. J Pediatr.2001;138:229-35. }\end{array}$ & IV \\
\hline 95 & $\begin{array}{l}\text { Chaimay, B.,Ruagdaraganon, N.,Thinkhamrop, B.,Thinkhamrop, J. Association between infant feeding practices and first } \\
\text { meaningful words at first year of life: a prospective cohort study of Thai children. Asia Pac J Public Health.2015;27:Np1071-84. }\end{array}$ & IV \\
\hline 96 & $\begin{array}{l}\text { Chan,G. M.,Roberts,C. C.,Folland,D.,Jackson,R. Growth and bone mineralization of normal breast-fed infants and the effects of } \\
\text { lactation on maternal bone mineral status. Am J Clin Nutr.1982;36:438-43. }\end{array}$ & IV \\
\hline 97 & $\begin{array}{l}\text { Chang, S. Y.,He, W.,Chen, C. M. Complementary feeding and growth of infant and young child in China. Biomed Environ } \\
\text { Sci.2008;21:264-8. }\end{array}$ & Design \\
\hline 98 & Chatterjee, M. K. Feeding pattern practised by the mothers attending an under five clinic. Indian J Public Health.1987;31:268-9. & Design \\
\hline 99 & Chavez A,Martinez C,Schlaepfer L. Health effects of supplementary feeding programs. Prog Clin Biol Res.1981;67:129-39. & Design \\
\hline 100 & Chawla, P.,Puri, R.,Pershad, D. Impact of pre-school supplementary feeding on mental abilities. Indian Pediatr.1983;20:513-6. & Age \\
\hline 101 & Chawla, P.,Puri, R. Impact of pre-school supplementary feeding programme on anthropometry. Indian Pediatr.1983;20:363-7. & Age \\
\hline 102 & $\begin{array}{l}\text { Cheng, T. S.,Loy, S. L.,Cheung, Y. B.,Chan, J. K.,Pang, W. W.,Godfrey, K. M.,Gluckman, P. D.,Kwek, K.,Saw, S. M.,Chong, Y. } \\
\text { S.,Lee, Y. S.,Lek, N.,Yap, F. Sexually dimorphic response to feeding mode in the growth of infants. Am J Clin } \\
\text { Nutr.2016;103:398-405. }\end{array}$ & IV \\
\hline 103 & $\begin{array}{l}\text { Chirmulay, D.,Nisal, R. Nutritional status of tribal underfive children in Ahmadnagar District, Maharashtra in relation to } \\
\text { weaning/feeding practices. Indian Pediatr.1993;30:215-22. }\end{array}$ & Design \\
\hline 104 & $\begin{array}{l}\text { Chitra, P. Development of banana-based weaning food mixes for infants and its nutritional quality evaluation. Rev Environ } \\
\text { Health.2015;30:125-30. }\end{array}$ & IV \\
\hline 105 & $\begin{array}{l}\text { Chivers, P.,Hands, B.,Parker, H.,Bulsara, M.,Beilin, L. J.,Kendall, G. E.,Oddy, W. H. Body mass index, adiposity rebound and } \\
\text { early feeding in a longitudinal cohort (Raine Study). Int J Obes (Lond).2010;34:1169-76. }\end{array}$ & IV \\
\hline 106 & $\begin{array}{l}\text { Cho, H. N.,Hong, S.,Lee, S. H.,Yum, H. Y. Nutritional status according to sensitized food allergens in children with atopic } \\
\text { dermatitis. Allergy, Asthma and Immunology Research.2010;3:53-57. }\end{array}$ & $\begin{array}{l}\text { Design, } \\
\text { IV, DV }\end{array}$ \\
\hline 107 & $\begin{array}{l}\text { Chorell,E.,Karlsson Videhult,F.,Hernell,O.,Antti,H.,West,C. E. Impact of probiotic feeding during weaning on the serum lipid profile } \\
\text { and plasma metabolome in infants. Br J Nutr.2013;110:116-26. }\end{array}$ & IV \\
\hline 108 & $\begin{array}{l}\text { Choudhury, N.,Bromage, S.,Alam, M. A.,Ahmed, A. M.,Islam, M. M.,Hossain, M. I.,Mahfuz, M.,Mondal, D.,Haque, M. R.,Ahmed, } \\
\text { T. Intervention study shows suboptimal growth among children receiving a food supplement for five months in a slum in } \\
\text { Bangladesh. Acta Paediatr.2016. }\end{array}$ & $\begin{array}{l}\text { Health } \\
\text { status, IV }\end{array}$ \\
\hline 109 & Christoffel, K. A pediatric perspective on vegetarian nutrition. Clin Pediatr (Phila).1981;20:632-43. & Design \\
\hline
\end{tabular}




\begin{tabular}{|c|c|c|}
\hline 110 & Christopher, G. C. First food: the essential role of breastfeeding. Breastfeed Med.2009;4 Suppl 1:S9-s10. & Design \\
\hline 111 & $\begin{array}{l}\text { Chuang, C. H.,Yang, S. H.,Chang, P. J.,Chen, P. C.,Chen, Y. C. Dietary supplement intake by 6-month-old Taiwanese infants. J } \\
\text { Pediatr Gastroenterol Nutr.2012;54:71-6. }\end{array}$ & DV \\
\hline 112 & $\begin{array}{l}\text { Closa-Monasterolo, R.,Gispert-Llaurado, M.,Luque, V.,Ferre, N.,Rubio-Torrents, C.,Zaragoza-Jordana, M.,Escribano, J. Safety } \\
\text { and efficacy of inulin and oligofructose supplementation in infant formula: results from a randomized clinical trial. Clin } \\
\text { Nutr.2013;32:918-27. }\end{array}$ & IV \\
\hline 113 & $\begin{array}{l}\text { Cloutier, M. M.,Wiley, J.,Wang, Z.,Grant, A.,Gorin, A. A. The Early Childhood Obesity Prevention Program (ECHO): an } \\
\text { ecologically-based intervention delivered by home visitors for newborns and their mothers. BMC Public Health.2015;15:584. }\end{array}$ & Design \\
\hline 114 & Cockburn,F. Neonatal brain and dietary lipids. Arch Dis Child Fetal Neonatal Ed.1994;70:F1-2. & Design \\
\hline 115 & $\begin{array}{l}\text { Cohen RJ,Brown KH,Canahuati J,Rivera LL,Dewey KG. Effects of age of introduction of complementary foods on infant breast } \\
\text { milk intake, total energy intake, and growth: a randomised intervention study in Honduras. Lancet.1994;344:288-93. }\end{array}$ & Country \\
\hline 116 & $\begin{array}{l}\text { Cohen, R. J.,Brown, K. H.,Canahuati, J.,Rivera, L. L.,Dewey, K. G. Determinants of growth from birth to } 12 \text { months among } \\
\text { breast-fed Honduran infants in relation to age of introduction of complementary foods. Pediatrics.1995;96:504-10. }\end{array}$ & IV \\
\hline 117 & Coleman,B. L. Early introduction of non-formula cow's milk to southern Ontario infants. Can J Public Health.2006;97:187-90. & IV, DV \\
\hline 118 & $\begin{array}{l}\text { Colombo,J.,Carlson,S. E.,Cheatham,C. L.,Shaddy,D. J.,Kerling,E. H.,Thodosoff,J. M.,Gustafson,K. M.,Brez,C. Long-term effects } \\
\text { of LCPUFA supplementation on childhood cognitive outcomes. Am J Clin Nutr.2013;98:403-12. }\end{array}$ & IV \\
\hline 119 & $\begin{array}{l}\text { Coppi, S.,lacoponi, F.,Fommei, C.,Strambi, M. Growth trend during the first six months of life in male infants with different type of } \\
\text { feeding. Minerva Pediatr.2013;65:51-9. }\end{array}$ & IV \\
\hline 120 & $\begin{array}{l}\text { Costom, B. H.,Shore, D. Effect of a comprehensive nutritional program on the growth and ponderosity of infants. Clin Pediatr } \\
\text { (Phila).1983;22:105-11. }\end{array}$ & Design \\
\hline 121 & $\begin{array}{l}\text { Courage, M. L.,McCloy, U. R.,Herzberg, G. R.,Andrews, W. L.,Simmons, B. S.,McDonald, A. C.,Mercer, C. N.,Friel, J. K. Visual } \\
\text { acuity development and fatty acid composition of erythrocytes in full-term infants fed breast milk, commercial formula, or } \\
\text { evaporated milk. J Dev Behav Pediatr.1998;19:9-17. }\end{array}$ & IV \\
\hline 122 & Cusack, R. Dietary management of obese children and adolescents. Pediatr Ann.1984;13:455, 458-9, 462-4. & Design \\
\hline 123 & $\begin{array}{l}\text { Dagan, R.,Sofer, S.,Klish, W. J.,Hundt, G.,Saltz-Rennert, H.,Moses, S. W. Infant feeding practices among Bedouins in transition } \\
\text { from seminomadic to settlement conditions in the Negev area of Israel. Isr J Med Sci.1984;20:1029-34. }\end{array}$ & $\begin{array}{l}\text { Design, } \\
\text { DV }\end{array}$ \\
\hline 124 & $\begin{array}{l}\text { Dagnelie,P. C.,van Staveren,W. A.,Hautvast,J. G. Stunting and nutrient deficiencies in children on alternative diets. Acta Paediatr } \\
\text { Scand Suppl.1991;374:111-8. }\end{array}$ & DV \\
\hline 125 & $\begin{array}{l}\text { Dagnelie,P. C.,van Staveren,W. A.,Vergote,F. J.,Dingjan,P. G.,van den Berg,H.,Hautvast,J. G. Increased risk of vitamin B-12 and } \\
\text { iron deficiency in infants on macrobiotic diets. Am J Clin Nutr.1989;50:818-24. }\end{array}$ & $\begin{array}{l}\text { Design, } \\
\text { DV }\end{array}$ \\
\hline 126 & $\begin{array}{l}\text { Dagnelie,P. C.,van Staveren,W. A.,Verschuren,S. A.,Hautvast,J. G. Nutritional status of infants aged } 4 \text { to } 18 \text { months on } \\
\text { macrobiotic diets and matched omnivorous control infants: a population-based mixed-longitudinal study. I. Weaning pattern, }\end{array}$ & $\begin{array}{l}\text { Design, } \\
\text { DV }\end{array}$ \\
\hline
\end{tabular}




\begin{tabular}{|c|c|c|}
\hline & energy and nutrient intake. Eur J Clin Nutr.1989;43:311-23. & \\
\hline 127 & $\begin{array}{l}\text { Daniels, L. A.,Mallan, K. M.,Battistutta, D.,Nicholson, J. M.,Meedeniya, J. E.,Bayer, J. K.,Magarey, A. Child eating behavior } \\
\text { outcomes of an early feeding intervention to reduce risk indicators for child obesity: the NOURISH RCT. Obesity (Silver } \\
\text { Spring).2014;22:E104-11. }\end{array}$ & DV \\
\hline 128 & $\begin{array}{l}\text { Daniels, L. A., Mallan, K. M.,Battistutta, D.,Nicholson, J. M.,Perry, R.,Magarey, A. Evaluation of an intervention to promote } \\
\text { protective infant feeding practices to prevent childhood obesity: outcomes of the NOURISH RCT at } 14 \text { months of age and } 6 \\
\text { months post the first of two intervention modules. Int J Obes (Lond).2012;36:1292-8. }\end{array}$ & IV, DV \\
\hline 129 & $\begin{array}{l}\text { Daniels, L. A.,Mallan, K. M.,Nicholson, J. M.,Battistutta, D.,Magarey, A. Outcomes of an early feeding practices intervention to } \\
\text { prevent childhood obesity. Pediatrics.2013;132:e109-18. }\end{array}$ & IV \\
\hline 130 & $\begin{array}{l}\text { Daniels, L. A.,Mallan, K. M.,Nicholson, J. M.,Thorpe, K.,Nambiar, S.,Mauch, C. E., Magarey, A. An Early Feeding Practices } \\
\text { Intervention for Obesity Prevention. Pediatrics.2015;136:e40-9. }\end{array}$ & IV \\
\hline 131 & Daniels, M. C.,Adair, L. S. Breast-feeding influences cognitive development in Filipino children. J Nutr.2005;135:2589-95. & IV \\
\hline 132 & $\begin{array}{l}\text { Davidsson,L.,Sarker,S. A.,Jamil,K. A.,Sultana,S.,Hurrell,R. Regular consumption of a complementary food fortified with ascorbic } \\
\text { acid and ferrous fumarate or ferric pyrophosphate is as useful as ferrous sulfate in maintaining hemoglobin concentrations }>105 \\
\text { g/L in young Bangladeshi children. Am J Clin Nutr.2009;89:1815-20. }\end{array}$ & IV, DV \\
\hline 133 & $\begin{array}{l}\text { de Hoog ML,van Eijsden M,Stronks K,Gemke RJ,Vrijkotte TG. The role of infant feeding practices in the explanation for ethnic } \\
\text { differences in infant growth: the Amsterdam Born Children and their Development study. Br J Nutr.2011;106:1592-601. }\end{array}$ & Design \\
\hline 134 & $\begin{array}{l}\text { de Kanashiro, H. C.,Brown, K. H.,Lopez de Romana, G.,Lopez, T.,Black, R. E. Consumption of food and nutrients by infants in } \\
\text { Huascar (Lima), Peru. Am J Clin Nutr.1990;52:995-1004. }\end{array}$ & DV \\
\hline 135 & $\begin{array}{l}\text { de Villiers, A.,Senekal, M. Determinants of growth failure in 12-24-month-old children in a high-density urban slum community in } \\
\text { East London, South Africa. Eur J Clin Nutr.2002;56:1231-41. }\end{array}$ & Country \\
\hline 136 & $\begin{array}{l}\text { de Zegher, F.,Sebastiani, G.,Diaz, M.,Sanchez-Infantes, D.,Lopez-Bermejo, A.,Ibanez, L. Body composition and circulating high- } \\
\text { molecular-weight adiponectin and IGF-I in infants born small for gestational age: breast- versus formula-feeding. } \\
\text { Diabetes.2012;61:1969-73. }\end{array}$ & $\begin{array}{l}\text { Health } \\
\text { status, IV }\end{array}$ \\
\hline 137 & Delport, S. D.,Becker, P. J.,Bergh, A. Growth, feeding practices and infections in black infants. S Afr Med J.1997;87:57-61. & IV, DV \\
\hline 138 & $\begin{array}{l}\text { Dewey, K. G.,Cohen, R. J.,Rivera, L. L.,Canahuati, J.,Brown, K. H. Do exclusively breast-fed infants require extra protein?. } \\
\text { Pediatr Res.1996;39:303-7. }\end{array}$ & IV \\
\hline 139 & $\begin{array}{l}\text { Dewey, K. G.,Hawck, M. G.,Brown, K. H.,Lartey, A.,Cohen, R. J.,Peerson, J. M. Infant weight-for-length is positively associated } \\
\text { with subsequent linear growth across four different populations. Matern Child Nutr.2005;1:11-20. }\end{array}$ & IV \\
\hline 140 & $\begin{array}{l}\text { Dewey, K. G.,Heinig, M. J.,Nommsen, L. A.,Lonnerdal, B. Adequacy of energy intake among breast-fed infants in the DARLING } \\
\text { study: relationships to growth velocity, morbidity, and activity levels. Davis Area Research on Lactation, Infant Nutrition and } \\
\text { Growth. J Pediatr.1991;119:538-47. }\end{array}$ & IV \\
\hline
\end{tabular}




\begin{tabular}{|c|c|c|}
\hline 141 & $\begin{array}{l}\text { Dewey, K. G.,Lonnerdal, B. Milk and nutrient intake of breast-fed infants from } 1 \text { to } 6 \text { months: relation to growth and fatness. J } \\
\text { Pediatr Gastroenterol Nutr.1983;2:497-506. }\end{array}$ & IV \\
\hline 142 & $\begin{array}{l}\text { Dewey, K. G.,Peerson, J. M.,Brown, K. H.,Krebs, N. F.,Michaelsen, K. F.,Persson, L. A., Salmenpera, L.,Whitehead, R. G.,Yeung, } \\
\text { D. L. Growth of breast-fed infants deviates from current reference data: a pooled analysis of US, Canadian, and European data } \\
\text { sets. World Health Organization Working Group on Infant Growth. Pediatrics.1995;96:495-503. }\end{array}$ & Design \\
\hline 143 & $\begin{array}{l}\text { Dewey, K. G.,Peerson, J. M.,Heinig, M. J.,Nommsen, L. A.,Lonnerdal, B.,Lopez de Romana, G.,de Kanashiro, H. C.,Black, R. } \\
\text { E.,Brown, K. H. Growth patterns of breast-fed infants in affluent (United States) and poor (Peru) communities: implications for } \\
\text { timing of complementary feeding. Am J Clin Nutr.1992;56:1012-8. }\end{array}$ & IV, DV \\
\hline 144 & Dewey, K. G. Complementary feeding and infant growth and body composition. Pediatrics.2000;106:1281. & Design \\
\hline 145 & $\begin{array}{l}\text { Dewey,K. G.,Cohen,R. J.,Brown,K. H.,Rivera,L. L. Effects of exclusive breastfeeding for four versus six months on maternal } \\
\text { nutritional status and infant motor development: results of two randomized trials in Honduras. J Nutr.2001;131:262-7. }\end{array}$ & Country \\
\hline 146 & $\begin{array}{l}\text { Dewey,K. G.,Cohen,R. J.,Rivera,L. L.,Brown,K. H. Effects of age of introduction of complementary foods on iron status of breast- } \\
\text { fed infants in Honduras. Am J Clin Nutr.1998;67:878-84. }\end{array}$ & DV \\
\hline 147 & $\begin{array}{l}\text { Dewey,K. G.,Huffman,S. L. Maternal, infant, and young child nutrition: combining efforts to maximize impacts on child growth and } \\
\text { micronutrient status. Food Nutr Bull.2009;30:S187-9. }\end{array}$ & Design \\
\hline 148 & $\begin{array}{l}\text { Dewey,K. G.,Romero-Abal,M. E.,Quan de Serrano,J.,Bulux,J.,Peerson,J. M.,Eagle,P.,Solomons,N. W. Effects of discontinuing } \\
\text { coffee intake on iron status of iron-deficient Guatemalan toddlers: a randomized intervention study. Am J Clin Nutr.1997;66:168- } \\
76 .\end{array}$ & DV \\
\hline 149 & $\begin{array}{l}\text { Diaz, S.,Herreros, C.,Aravena, R.,Casado, M. E.,Reyes, M. V.,Schiappacasse, V. Breast-feeding duration and growth of fully } \\
\text { breast-fed infants in a poor urban Chilean population. Am J Clin Nutr.1995;62:371-6. }\end{array}$ & IV, DV \\
\hline 150 & $\begin{array}{l}\text { Doak, C. M.,van der Starre, R. E.,van Beusekom, I.,Campos Ponce, M.,Vossenaar, M.,Solomons, N. W. Earlier introduction of } \\
\text { aguitas is associated with higher risk of stunting in infants and toddlers in the Western Highlands of Guatemala. Am J Clin } \\
\text { Nutr.2013;97:631-6. }\end{array}$ & Design \\
\hline 151 & $\begin{array}{l}\text { Domellof,M.,Cohen,R. J.,Dewey,K. G.,Hernell,O.,Rivera,L. L.,Lonnerdal,B. Iron supplementation of breast-fed Honduran and } \\
\text { Swedish infants from } 4 \text { to } 9 \text { months of age. J Pediatr.2001;138:679-87. }\end{array}$ & IV, DV \\
\hline 152 & $\begin{array}{l}\text { Dong,C.,Ge,P.,Ren,X.,Wang,J.,Fan,H.,Yan,X.,Yin,S. A. Prospective study on the effectiveness of complementary food } \\
\text { supplements on improving status of elder infants and young children in the areas affected by Wenchuan earthquake. PLoS } \\
\text { One.2013;8:e72711. }\end{array}$ & $\begin{array}{l}\text { Design, } \\
\text { Health } \\
\text { status }\end{array}$ \\
\hline 153 & Donma, M. M.,Donma, O. Infant feeding and growth: a study on Turkish infants from birth to 6 months. Pediatr Int.1999;41:542-8. & IV \\
\hline 154 & $\begin{array}{l}\text { Donma, M. M.,Donma, O. The influence of feeding patterns on head circumference among Turkish infants during the first } 6 \\
\text { months of life. Brain Dev.1997;19:393-7. }\end{array}$ & IV \\
\hline 155 & $\begin{array}{l}\text { Dubakiene, R.,Rudzeviciene, O.,Butiene, I.,Sezaite, I.,Petronyte, M.,Vaicekauskaite, D.,Zvirbliene, A. Studies on early allergic } \\
\text { sensitization in the Lithuanian birth cohort. ScientificWorldJournal.2012;2012:909524. }\end{array}$ & IV, DV \\
\hline
\end{tabular}




\begin{tabular}{|c|c|c|}
\hline 156 & $\begin{array}{l}\text { Dubois, L.,Girard, M. Breast-feeding, day-care attendance and the frequency of antibiotic treatments from } 1.5 \text { to } 5 \text { years: a } \\
\text { population-based longitudinal study in Canada. Soc Sci Med.2005;60:2035-44. }\end{array}$ & IV, DV \\
\hline 157 & $\begin{array}{l}\text { Dubois, L., Girard, M. Social inequalities in infant feeding during the first year of life. The Longitudinal Study of Child Development } \\
\text { in Quebec (LSCDQ 1998-2002). Public Health Nutr.2003;6:773-83. }\end{array}$ & IV, DV \\
\hline 158 & $\begin{array}{l}\text { Dubowitz, T.,Levinson, D.,Peterman, J. N.,Verma, G.,Jacob, S.,Schultink, W. Intensifying efforts to reduce child malnutrition in } \\
\text { India: an evaluation of the Dular program in Jharkhand, India. Food Nutr Bull.2007;28:266-73. }\end{array}$ & IV \\
\hline 159 & $\begin{array}{l}\text { Duggan,C.,Penny,M. E.,Hibberd,P.,Gil,A.,Huapaya,A.,Cooper,A.,Coletta,F.,Emenhiser,C.,Kleinman,R. E. Oligofructose- } \\
\text { supplemented infant cereal: } 2 \text { randomized, blinded, community-based trials in Peruvian infants. Am J Clin Nutr.2003;77:937-42. }\end{array}$ & IV \\
\hline 160 & Dunne,A. Nutrition in infancy: achieving nutrition needs for new mothers and children. Br J Community Nurs.2012;Suppl:S22. & Design \\
\hline 161 & Edmondson, L. What toddlers eat really matters. J Fam Health Care.2011;21:33-41. & Design \\
\hline 162 & $\begin{array}{l}\text { El-Sayed H,Martines J,Rakha M,Zekry O,Abdel-Hak M,Abbas H. The effectiveness of the WHO training course on } \\
\text { complementary feeding counseling in a primary care setting, Ismailia, Egypt. J Egypt Public Health Assoc.2014;89:1-8. }\end{array}$ & IV \\
\hline 163 & $\begin{array}{l}\text { Elwood, P. C.,Haley, T. J.,Hughes, S. J.,Sweetnam, P. M.,Gray, O. P.,Davies, D. P. Child growth (0-5 years), and the effect of } \\
\text { entitlement to a milk supplement. Arch Dis Child.1981;56:831-5. }\end{array}$ & IV \\
\hline 164 & $\begin{array}{l}\text { Emmett,P. M.,Jones,L. R. Diet and growth in infancy: relationship to socioeconomic background and to health and development } \\
\text { in the Avon Longitudinal Study of Parents and Children. Nutr Rev.2014;72:483-506. }\end{array}$ & Design \\
\hline 165 & $\begin{array}{l}\text { Emond A,Drewett R,Blair P,Emmett P. Postnatal factors associated with failure to thrive in term infants in the Avon Longitudinal } \\
\text { Study of Parents and Children. Arch Dis Child.2007;92:115-9. }\end{array}$ & IV \\
\hline 166 & $\begin{array}{l}\text { Eneroth,H.,El Arifeen,S.,Persson,L. A., Kabir,I,Lonnerdal,B.,Hossain,M. B.,Ekstrom,E. C. Duration of exclusive breast-feeding } \\
\text { and infant iron and zinc status in rural Bangladesh. J Nutr.2009;139:1562-7. }\end{array}$ & IV, DV \\
\hline 167 & $\begin{array}{l}\text { Engelmann,M. D.,Davidsson,L.,Sandstrom,B.,Walczyk,T.,Hurrell,R. F.,Michaelsen,K. F. The influence of meat on nonheme iron } \\
\text { absorption in infants. Pediatr Res.1998;43:768-73. }\end{array}$ & DV \\
\hline 168 & $\begin{array}{l}\text { England, L.,Brenner, R.,Bhaskar, B.,Simons-Morton, B.,Das, A., Revenis, M.,Mehta, N.,Clemens, J. Breastfeeding practices in a } \\
\text { cohort of inner-city women: the role of contraindications. BMC Public Health.2003;3:28. }\end{array}$ & IV, DV \\
\hline 169 & $\begin{array}{l}\text { Escribano, J.,Luque, V.,Ferre, N.,Mendez-Riera, G.,Koletzko, B.,Grote, V.,Demmelmair, H.,Bluck, L.,Wright, A.,Closa- } \\
\text { Monasterolo, R. Effect of protein intake and weight gain velocity on body fat mass at } 6 \text { months of age: the EU Childhood Obesity } \\
\text { Programme. Int J Obes (Lond).2012;36:548-53. }\end{array}$ & IV \\
\hline 170 & $\begin{array}{l}\text { Esfarjani, F.,Azar, M. R.,Gafarpour, M. IDDM and early exposure of infant to cow's milk and solid food. Indian J } \\
\text { Pediatr.2001;68:107-10. }\end{array}$ & DV \\
\hline 171 & Evans, D.,Hansen, J. D.,Moodie, A. D.,van der Spuy, H. I. Intellectual development and nutrition. J Pediatr.1980;97:358-63. & $\begin{array}{l}\text { Health } \\
\text { status, IV }\end{array}$ \\
\hline 172 & $\begin{array}{l}\text { Exl, B. M.,Deland, U.,Secretin, M. C.,Preysch, U.,Wall, M.,Shmerling, D. H. Improved general health status in an unselected } \\
\text { infant population following an allergen reduced dietary intervention programme. The ZUFF-study-programme. Part I: Study design }\end{array}$ & DV \\
\hline
\end{tabular}




\begin{tabular}{|c|c|c|}
\hline & and 6-month nutritional behaviour. Eur J Nutr.2000;39:89-102. & \\
\hline 173 & $\begin{array}{l}\text { Exl, B. M.,Deland, U.,Secretin, M. C.,Preysch, U.,Wall, M.,Shmerling, D. H. Improved general health status in an unselected } \\
\text { infant population following an allergen-reduced dietary intervention programme: the ZUFF-STUDY-PROGRAMME. Part II: infant } \\
\text { growth and health status to age } 6 \text { months. ZUg-FrauenFeld. Eur J Nutr.2000;39:145-56. }\end{array}$ & IV \\
\hline 174 & $\begin{array}{l}\text { Faber,M.,Kvalsvig,J. D.,Lombard,C. J.,Benade,A. J. Effect of a fortified maize-meal porridge on anemia, micronutrient status, and } \\
\text { motor development of infants. Am J Clin Nutr.2005;82:1032-9. }\end{array}$ & Country \\
\hline 175 & $\begin{array}{l}\text { Faber,M. Dietary intake and anthropometric status differ for anaemic and non-anaemic rural South African infants aged 6-12 } \\
\text { months. J Health Popul Nutr.2007;25:285-93. }\end{array}$ & Design \\
\hline 176 & $\begin{array}{l}\text { Fabiansen, C.,Phelan, K. P.,Cichon, B.,Ritz, C.,Briend, A.,Michaelsen, K. F.,Friis, H.,Shepherd, S. Short children with a low } \\
\text { midupper arm circumference respond to food supplementation: an observational study from Burkina Faso. Am J Clin } \\
\text { Nutr.2016;103:415-21. }\end{array}$ & $\begin{array}{l}\text { Health } \\
\text { status }\end{array}$ \\
\hline 177 & $\begin{array}{l}\text { Fabius, R. J.,Merritt, R. J.,Fleiss, P. M.,Ashley, J. M. Malnutrition associated with a formula of barley water, corn syrup, and whole } \\
\text { milk. Am J Dis Child.1981;135:615-7. }\end{array}$ & Design \\
\hline 178 & Falkner, F. Introduction of food to infants. Genetic-environmental considerations. Am J Clin Nutr.1985;41:436-9. & Design \\
\hline 179 & $\begin{array}{l}\text { Fall CH,Borja JB,Osmond C,Richter L,Bhargava SK,Martorell R,Stein AD,Barros FC,Victora CG. Infant-feeding patterns and } \\
\text { cardiovascular risk factors in young adulthood: data from five cohorts in low- and middle-income countries. Int J } \\
\text { Epidemiol.2011;40:47-62. }\end{array}$ & Design \\
\hline 180 & $\begin{array}{l}\text { Farris, R. P.,Frank, G. C.,Webber, L. S., Srinivasan, S. R.,Berenson, G. S. Influence of milk source on serum lipids and } \\
\text { lipoproteins during the first year of life, Bogalusa heart study. Am J Clin Nutr.1982;35:42-9. }\end{array}$ & IV \\
\hline 181 & Farrow, C. V.,Blissett, J. Controlling feeding practices: cause or consequence of early child weight?. Pediatrics.2008;121:e164-9. & IV \\
\hline 182 & Farrow, C.,Blissett, J. Does maternal control during feeding moderate early infant weight gain?. Pediatrics.2006;118:e293-8. & IV \\
\hline 183 & Fawcett, J. N. Feeding from birth to 18 months. Nursing (Lond).1981:956-8. & Design \\
\hline 184 & $\begin{array}{l}\text { Feldens CA,Vitolo MR, Rauber F,Cruz LN,Hilgert JB. Risk factors for discontinuing breastfeeding in southern Brazil: a survival } \\
\text { analysis. Matern Child Health J.2012;16:1257-65. }\end{array}$ & IV, DV \\
\hline 185 & $\begin{array}{l}\text { Feldens, C. A.,Ardenghi, T. M.,Cruz, L. N.,Scalco, G. P.,Vitolo, M. R. Advising mothers about breastfeeding and weaning reduced } \\
\text { pacifier use in the first year of life: a randomized trial. Community Dent Oral Epidemiol.2013;41:317-26. }\end{array}$ & IV, DV \\
\hline 186 & $\begin{array}{l}\text { Feldens, C. A.,Kramer, P. F.,Sequeira, M. C.,Rodrigues, P. H.,Vitolo, M. R. Maternal education is an independent determinant of } \\
\text { cariogenic feeding practices in the first year of life. Eur Arch Paediatr Dent.2012;13:70-5. }\end{array}$ & DV \\
\hline 187 & $\begin{array}{l}\text { Fergusson, D. M.,Woodward, L. J. Breast feeding and later psychosocial adjustment. Paediatr Perinat Epidemiol.1999;13:144- } \\
57 .\end{array}$ & IV \\
\hline 188 & Fernandes, T. A.,Werneck, G. L.,Hasselmann, M. H. Prepregnancy weight, weight gain during pregnancy, and exclusive & IV, DV \\
\hline
\end{tabular}




\begin{tabular}{|c|c|c|}
\hline & breastfeeding in the first month of Life in Rio de Janeiro, Brazil. J Hum Lact.2012;28:55-61. & \\
\hline 189 & $\begin{array}{l}\text { Fernstrom, J. D.,Navia, J. L. Introduction to the workshop. Low-calorie sweeteners and weight control--what the science tells us. } \\
\text { J Nutr.2012;142:1132s-3s. }\end{array}$ & Design \\
\hline 190 & $\begin{array}{l}\text { Ferrara,M.,Bertocco,F.,Ricciardi,A.,Ferrara,D.,Incarnato,L.,Capozzi,L. Iron deficiency screening in the first three years of life: a } \\
\text { three-decade-long retrospective case study. Hematology.2014;19:239-43. }\end{array}$ & DV \\
\hline 191 & $\begin{array}{l}\text { Fildes, A.,van Jaarsveld, C. H.,Llewellyn, C.,Wardle, J.,Fisher, A. Parental control over feeding in infancy. Influence of infant } \\
\text { weight, appetite and feeding method. Appetite.2015;91:101-6. }\end{array}$ & IV, DV \\
\hline 192 & $\begin{array}{l}\text { Fisher, J. O.,Birch, L. L.,Smiciklas-Wright, H.,Picciano, M. F. Breast-feeding through the first year predicts maternal control in } \\
\text { feeding and subsequent toddler energy intakes. J Am Diet Assoc.2000;100:641-6. }\end{array}$ & IV, DV \\
\hline 193 & $\begin{array}{l}\text { Flax, V. L.,Bentley, M. E.,Chasela, C. S.,Kayira, D.,Hudgens, M. G.,Kacheche, K. Z.,Chavula, C.,Kourtis, A. P.,Jamieson, D. } \\
\text { J.,van der Horst, C. M.,Adair, L. S. Lipid-based nutrient supplements are feasible as a breastmilk replacement for HIV-exposed } \\
\text { infants from } 24 \text { to } 48 \text { weeks of age. J Nutr.2013;143:701-7. }\end{array}$ & $\begin{array}{l}\text { Health } \\
\text { status, IV }\end{array}$ \\
\hline 194 & $\begin{array}{l}\text { Fomon SJ,Ziegler EE,Nelson SE,Edwards BB. Sweetness of diet and food consumption by infants. Proc Soc Exp Biol } \\
\text { Med.1983;173:190-3. }\end{array}$ & IV, DV \\
\hline 195 & $\begin{array}{l}\text { Fomon, S. J.,Rogers, R. R.,Ziegler, E. E.,Nelson, S. E.,Thomas, L. N. Indices of fatness and serum cholesterol at age eight years } \\
\text { in relation to feeding and growth during early infancy. Pediatr Res.1984;18:1233-8. }\end{array}$ & IV, Date \\
\hline 196 & $\begin{array}{l}\text { Forns,J.,Torrent,M.,Garcia-Esteban,R.,Caceres,A.,Pilar Gomila,M.,Martinez,D.,Morales,E.,Julvez,J.,Grimalt,J. O.,Sunyer,J. } \\
\text { Longitudinal association between early life socio-environmental factors and attention function at the age } 11 \text { years. Environ } \\
\text { Res.2012;117:54-9. }\end{array}$ & IV \\
\hline 197 & $\begin{array}{l}\text { Foroushani, A. R.,Mohammad, K.,Mahmoodi, M.,Siassi, F. Effect of breastfeeding on cognitive performance in a British birth } \\
\text { cohort. East Mediterr Health J.2010;16:202-8. }\end{array}$ & IV \\
\hline 198 & $\begin{array}{l}\text { Franks, A. J.,Jurgensen, C. Nutrition and health in the first year of life on a Pacific atoll. Observations on Abemama Atoll, Central } \\
\text { Pacific. Trans R Soc Trop Med Hyg.1985;79:681-4. }\end{array}$ & IV, DV \\
\hline 199 & $\begin{array}{l}\text { Frederiksen,B. N.,Seifert,J.,Kroehl,M.,Lamb,M. M.,Milne,G. L.,Rewers,M.,Norris,J. M. Timing of solid food introduction is } \\
\text { associated with urinary F2-isoprostane concentrations in childhood. Pediatric Research.2015;78:451-456. }\end{array}$ & DV \\
\hline 200 & $\begin{array}{l}\text { Freeman, V.,van't Hof, M.,Haschke, F. Patterns of milk and food intake in infants from birth to age } 36 \text { months: the Euro-growth } \\
\text { study. J Pediatr Gastroenterol Nutr.2000;31 Suppl 1:S76-85. }\end{array}$ & DV \\
\hline 201 & $\begin{array}{l}\text { Freeman,V. E.,Mulder,J.,van't Hof,M. A.,Hoey,H. M.,Gibney,M. J. A longitudinal study of iron status in children at } 12,24 \text { and } 36 \\
\text { months. Public Health Nutr.1998;1:93-100. }\end{array}$ & DV \\
\hline 202 & $\begin{array}{l}\text { Friel,J. K.,Andrews,W. L.,Simmons,B. S.,L'Abbe,M. R.,Mercer,C.,MacDonald,A.,McCloy,U. R. Evaluation of full-term infants fed } \\
\text { an evaporated milk formula. Acta Paediatr.1997;86:448-53. }\end{array}$ & IV \\
\hline 203 & $\begin{array}{l}\text { Froozani, M. D.,Malekafzali, H.,Bahrini, B. Growth of a group of low income infants in the first year of life. J Trop } \\
\text { Pediatr.1980;26:96-8. }\end{array}$ & Design, IV \\
\hline
\end{tabular}




\begin{tabular}{|c|c|c|}
\hline 204 & $\begin{array}{l}\text { Fuchs lii, G. J.,Gastanaduy, A. S.,Suskind, R. M. Comparative metabolic study of older infants fed infant formula, transition } \\
\text { formula, or whole cow's milk. Nutrition Research.1992;12:1467-1478. }\end{array}$ & IV \\
\hline 205 & $\begin{array}{l}\text { Fuchs, G. J.,Farris, R. P.,DeWier, M.,Hutchinson, S.,Strada, R.,Suskind, R. M. Effect of dietary fat on cardiovascular risk factors } \\
\text { in infancy. Pediatrics.1994;93:756-63. }\end{array}$ & IV \\
\hline 206 & $\begin{array}{l}\text { Gabriel, C. G.,Corso, A. C.,Caldeira, G. V.,Gimeno, S. G.,Schmitz Bde, A.,de Vasconcelos Fde, A. Overweight and obesity } \\
\text { related factors in schoolchildren in Santa Catarina State, Brazil. Arch Latinoam Nutr.2010;60:332-9. }\end{array}$ & Design \\
\hline 207 & $\begin{array}{l}\text { Gaffney, K. F.,Brito, A. V.,Kitsantas, P.,Kermer, D. A. Early Feeding Practices and Weight Status at One Year of Age: A } \\
\text { Comparison of Hispanic Immigrant Mother-Infant Dyads with Participants of the Infant Feeding Practices Study II. Child } \\
\text { Obes.2016. }\end{array}$ & IV, DV \\
\hline 208 & $\begin{array}{l}\text { Gale, C.,Thomas, E. L.,Jeffries, S.,Durighel, G.,Logan, K. M.,Parkinson, J. R.,Uthaya, S.,Santhakumaran, S.,Bell, J. D.,Modi, N. } \\
\text { Adiposity and hepatic lipid in healthy full-term, breastfed, and formula-fed human infants: a prospective short-term longitudinal } \\
\text { cohort study. Am J Clin Nutr.2014;99:1034-40. }\end{array}$ & IV \\
\hline 209 & $\begin{array}{l}\text { Galler, J. R.,Ramsey, F. C.,Harrison, R. H.,Brooks, R.,Weiskopf-Bock, S. Infant feeding practices in Barbados predict later } \\
\text { growth. J Nutr.1998;128:1328-35. }\end{array}$ & IV \\
\hline 210 & $\begin{array}{l}\text { Gallo PV. Physiological and behavioral consequences of maternal and post-weaning protein restriction. Physiol } \\
\text { Behav.1981;26:77-84. }\end{array}$ & $\begin{array}{l}\text { Design, } \\
\text { Health } \\
\text { status }\end{array}$ \\
\hline 211 & $\begin{array}{l}\text { Galtry, J. Punching above its weight: does New Zealand's responsibility for protecting, promoting, and supporting breastfeeding } \\
\text { extend beyond its own borders?. J Hum Lact.2013;29:128-31. }\end{array}$ & Design \\
\hline 212 & $\begin{array}{l}\text { Garza, C. The INTERGROWTH-21st project and the multicenter growth reference study: enhanced opportunities for monitoring } \\
\text { growth from early pregnancy to } 5 \text { years of age. Breastfeed Med.2014;9:341-4. }\end{array}$ & Design \\
\hline 213 & $\begin{array}{l}\text { Geuns, M.,Huisinga, C.,van Staveren, W. A.,Deurenberg, P.,Hautvast, J. G. Intakes of energy, protein and calcium and weaning } \\
\text { pattern of a group of Dutch infants aged 6-12 months. Tijdschr Kindergeneeskd.1985;53:50-6. }\end{array}$ & $\begin{array}{l}\text { Design, IV, } \\
\text { DV }\end{array}$ \\
\hline 214 & $\begin{array}{l}\text { Ghorashi,Z.,Nezami,N.,Ghalehgolab Behbahan,A.,Ghorashi,S. Supplemental food may not prevent iron-deficiency anemia in } \\
\text { infants. Indian J Pediatr.2008;75:1121-4. }\end{array}$ & DV \\
\hline 215 & $\begin{array}{l}\text { Ghosh,S.,Kilaru,A.,Ganapathy,S. Nutrition education and infant growth in rural Indian infants: narrowing the gender gap?. J } \\
\text { Indian Med Assoc.2002;100:483-4, 486-8, 490. }\end{array}$ & IV \\
\hline 216 & $\begin{array}{l}\text { Gianni, M. L.,Roggero, P.,Morlacchi, L.,Garavaglia, E.,Piemontese, P.,Mosca, F. Formula-fed infants have significantly higher fat- } \\
\text { free mass content in their bodies than breastfed babies. Acta Paediatr.2014;103:e277-81. }\end{array}$ & IV \\
\hline 217 & Gibson,R. S.,Hotz,C. The adequacy of micronutrients in complementary foods. Pediatrics.2000;106:1298-9. & Design \\
\hline 218 & $\begin{array}{l}\text { Gill, D. G.,Vincent, S.,Segal, D. S. Follow-on formula in the prevention of iron deficiency: a multicentre study. Acta } \\
\text { Paediatr.1997;86:683-9. }\end{array}$ & IV \\
\hline 219 & $\begin{array}{l}\text { Gillman, M. W.,Rifas-Shiman, S. L.,Camargo, C. A., Jr.,Berkey, C. S.,Frazier, A. L.,Rockett, H. R.,Field, A. E.,Colditz, G. A. Risk } \\
\text { of overweight among adolescents who were breastfed as infants. Jama.2001;285:2461-7. }\end{array}$ & Design \\
\hline
\end{tabular}




\begin{tabular}{|c|c|c|}
\hline 220 & $\begin{array}{l}\text { Gokcay, G.,Turan, J. M.,Partalci, A.,Neyzi, O. Growth of infants during the first year of life according to feeding regimen in the first } \\
4 \text { months. J Trop Pediatr.2003;49:6-12. }\end{array}$ & IV \\
\hline 221 & $\begin{array}{l}\text { Golley,R. K.,Smithers,L. G.,Mittinty,M. N.,Brazionis,L.,Emmett,P.,Northstone,K.,Campbell,K.,McNaughton,S. A.,Lynch,J. W. An } \\
\text { index measuring adherence to complementary feeding guidelines has convergent validity as a measure of infant diet quality. J } \\
\text { Nutr.2012;142:901-8. }\end{array}$ & IV, DV \\
\hline 222 & $\begin{array}{l}\text { Gomez Santos, S. F.,Estevez Santiago, R.,Palacios Gil-Antunano, N.,Leis Trabazo, M. R.,Tojo Sierra, R.,Cuadrado Vives, } \\
\text { C.,Beltran de Miguel, B.,Avila Torres, J. M.,Varela Moreiras, G.,Casas Esteve, R. THAO-CHILD HEALTH PROGRAMME: } \\
\text { COMMUNITY BASED INTERVENTION FOR HEALTHY LIFESTYLES PROMOTION TO CHILDREN AND FAMILIES: RESULTS } \\
\text { OF A COHORT STUDY. Nutr Hosp.2015;32:2584-7. }\end{array}$ & Age \\
\hline 223 & $\begin{array}{l}\text { Gomez-Sanchiz, M.,Canete, R.,Rodero, I.,Baeza, J. E.,Avila, O. Influence of breast-feeding on mental and psychomotor } \\
\text { development. Clin Pediatr (Phila).2003;42:35-42. }\end{array}$ & IV \\
\hline 224 & $\begin{array}{l}\text { Gomez-Sanchiz, M.,Canete, R.,Rodero, I.,Baeza, J. E.,Gonzalez, J. A. Influence of breast-feeding and parental intelligence on } \\
\text { cognitive development in the 24-month-old child. Clin Pediatr (Phila).2004;43:753-61. }\end{array}$ & IV \\
\hline 225 & $\begin{array}{l}\text { Gong, Y. H.,Ji, C. Y.,Zheng, X. X.,Shan, J. P.,Hou, R. Correlation of 4-month infant feeding modes with their growth and iron } \\
\text { status in Beijing. Chin Med J (Engl).2008;121:392-8. }\end{array}$ & IV \\
\hline 226 & $\begin{array}{l}\text { Gooze, R. A.,Anderson, S. E.,Whitaker, R. C. Prolonged bottle use and obesity at } 5.5 \text { years of age in US children. J } \\
\text { Pediatr.2011;159:431-6. }\end{array}$ & IV \\
\hline 227 & $\begin{array}{l}\text { Greene, L. C., Lucas, A.,Livingstone, M. B.,Harland, P. S.,Baker, B. A. Relationship between early diet and subsequent cognitive } \\
\text { performance during adolescence. Biochem Soc Trans.1995;23:376s. }\end{array}$ & Design, IV \\
\hline 228 & $\begin{array}{l}\text { Greer,F. R.,Searcy,J. E.,Levin,R. S.,Steichen,J. J.,Steichen-Asche,P. S.,Tsang,R. C. Bone mineral content and serum 25- } \\
\text { hydroxyvitamin D concentrations in breast-fed infants with and without supplemental vitamin D: one-year follow-up. J } \\
\text { Pediatr.1982;100:919-22. }\end{array}$ & IV \\
\hline 229 & $\begin{array}{l}\text { Grote, V.,von Kries, R.,Closa-Monasterolo, R., Scaglioni, S., Gruszfeld, D.,Sengier, A.,Langhendries, J. P.,Koletzko, B. Protein } \\
\text { intake and growth in the first } 24 \text { months of life. J Pediatr Gastroenterol Nutr.2010;51 Suppl 3:S117-8. }\end{array}$ & Design, IV \\
\hline 230 & $\begin{array}{l}\text { Gruszfeld, D.,Weber, M.,Nowakowska-Rysz, M.,Janas, R.,Kozlik-Feldmann, R.,Xhonneux, A.,Carlier, C.,Riva, E.,Verduci, } \\
\text { E.,Closa-Monasterolo, R.,Escribano, J.,Dobrzanska, A.,Koletzko, B. Protein intake in infancy and carotid intima media thickness } \\
\text { at } 5 \text { years--a secondary analysis from a randomized trial. Ann Nutr Metab.2015;66:51-9. }\end{array}$ & IV \\
\hline 231 & $\begin{array}{l}\text { Gubbels, J. S., Thijs, C., Stafleu, A.,van Buuren, S.,Kremers, S. P. Association of breast-feeding and feeding on demand with child } \\
\text { weight status up to } 4 \text { years. Int J Pediatr Obes.2011;6:e515-22. }\end{array}$ & IV, DV \\
\hline 232 & $\begin{array}{l}\text { Gunderson, E. P.,Hurston, S. R.,Dewey, K. G.,Faith, M. S.,Charvat-Aguilar, N.,Khoury, V. C.,Nguyen, V. T.,Quesenberry, C. P., } \\
\text { Jr. The study of women, infant feeding and type } 2 \text { diabetes after GDM pregnancy and growth of their offspring (SWIFT Offspring } \\
\text { study): prospective design, methodology and baseline characteristics. BMC Pregnancy Childbirth.2015;15:150. }\end{array}$ & Design \\
\hline 233 & $\begin{array}{l}\text { Gunnarsdottir I,Schack-Nielsen L,Michaelsen KF, Sorensen TI,Thorsdottir I. Infant weight gain, duration of exclusive breast- } \\
\text { feeding and childhood BMI - two similar follow-up cohorts. Public Health Nutr.2010;13:201-7. }\end{array}$ & IV \\
\hline
\end{tabular}




\begin{tabular}{|c|c|c|}
\hline 234 & $\begin{array}{l}\text { Gunnarsdottir, I.,Thorsdottir, I. Relationship between growth and feeding in infancy and body mass index at the age of } 6 \text { years. } \\
\text { Int J Obes Relat Metab Disord.2003;27:1523-7. }\end{array}$ & IV \\
\hline 235 & $\begin{array}{l}\text { Gunther, A. L.,Buyken, A. E.,Kroke, A. Protein intake during the period of complementary feeding and early childhood and the } \\
\text { association with body mass index and percentage body fat at } 7 \text { y of age. Am J Clin Nutr.2007;85:1626-33. }\end{array}$ & IV \\
\hline 236 & $\begin{array}{l}\text { Gunther, A. L.,Buyken, A. E.,Kroke, A. The influence of habitual protein intake in early childhood on BMI and age at adiposity } \\
\text { rebound: results from the DONALD Study. Int J Obes (Lond).2006;30:1072-9. }\end{array}$ & IV \\
\hline 237 & $\begin{array}{l}\text { Gurnida, D. A., Rowan, A. M.,Idjradinata, P.,Muchtadi, D.,Sekarwana, N. Association of complex lipids containing gangliosides } \\
\text { with cognitive development of 6-month-old infants. Early Hum Dev.2012;88:595-601. }\end{array}$ & IV \\
\hline 238 & $\begin{array}{l}\text { Hamilton, K.,Daniels, L.,White, K. M.,Murray, N.,Walsh, A. Predicting mothers' decisions to introduce complementary feeding at } 6 \\
\text { months. An investigation using an extended theory of planned behaviour. Appetite.2011;56:674-81. }\end{array}$ & IV, DV \\
\hline 239 & $\begin{array}{l}\text { Hammer, L. D.,Bryson, S.,Agras, W. S. Development of feeding practices during the first } 5 \text { years of life. Arch Pediatr Adolesc } \\
\text { Med.1999;153:189-94. }\end{array}$ & DV \\
\hline 240 & $\begin{array}{l}\text { Han,Y. H.,Yon,M.,Han,H. S.,Johnston,K. E.,Tamura,T.,Hyun,T. Zinc status and growth of Korean infants fed human milk, casein- } \\
\text { based, or soy-based formula: three-year longitudinal study. Nutr Res Pract.2011;5:46-51. }\end{array}$ & IV \\
\hline 241 & $\begin{array}{l}\text { Harbild, H. L., Harslof, L. B.,Christensen, J. H.,Kannass, K. N.,Lauritzen, L. Fish oil-supplementation from } 9 \text { to } 12 \text { months of age } \\
\text { affects infant attention in a free-play test and is related to change in blood pressure. Prostaglandins Leukot Essent Fatty } \\
\text { Acids.2013;89:327-33. }\end{array}$ & IV \\
\hline 242 & $\begin{array}{l}\text { Harit D,Faridi MM,Aggarwal A,Sharma SB. Lipid profile of term infants on exclusive breastfeeding and mixed feeding: a } \\
\text { comparative study. Eur J Clin Nutr.2008;62:203-9. }\end{array}$ & IV \\
\hline 243 & $\begin{array}{l}\text { Harrington,M.,Hotz,C.,Zeder,C.,Polvo,G. O.,Villalpando,S.,Zimmermann,M. B.,Walczyk,T.,Rivera,J. A.,Hurrell,R. F. A comparison } \\
\text { of the bioavailability of ferrous fumarate and ferrous sulfate in non-anemic Mexican women and children consuming a sweetened } \\
\text { maize and milk drink. Eur J Clin Nutr.2011;65:20-5. }\end{array}$ & IV, DV \\
\hline 244 & Harris, R. Inadequate diets: short- and long-term problems. J Fam Health Care.2002;12:6. & Design \\
\hline 245 & $\begin{array}{l}\text { Hasan,J.,Ray,J.,Khan,Z. Role of weaning in the nutritional status of infant--a longitudinal study in the rural area of Aligarh. J } \\
\text { Indian Med Assoc.1996;94:169, } 215 \text {. }\end{array}$ & $\begin{array}{l}\text { Design, IV, } \\
\text { DV }\end{array}$ \\
\hline 246 & $\begin{array}{l}\text { Haschke, F.,Pietschnig, B.,Vanura, H.,Heil, M.,Steffan, I.,Hobiger, G.,Schuster, E.,Camaya, Z. Iron intake and iron nutritional } \\
\text { status of infants fed iron-fortified beikost with meat. Am J Clin Nutr.1988;47:108-12. }\end{array}$ & IV \\
\hline 247 & $\begin{array}{l}\text { Hawley, N. L.,Johnson, W.,Nu'usolia, O.,McGarvey, S. T. The contribution of feeding mode to obesogenic growth trajectories in } \\
\text { American Samoan infants. Pediatr Obes.2014;9:e1-e13. }\end{array}$ & IV \\
\hline 248 & $\begin{array}{l}\text { Hay,G.,Johnston,C.,Whitelaw,A.,Trygg,K.,Refsum,H. Folate and cobalamin status in relation to breastfeeding and weaning in } \\
\text { healthy infants. Am J Clin Nutr.2008;88:105-14. }\end{array}$ & DV \\
\hline 249 & $\begin{array}{l}\text { Hediger, M. L., Overpeck, M. D.,Ruan, W. J.,Troendle, J. F. Early infant feeding and growth status of US-born infants and children } \\
\text { aged 4-71 mo: analyses from the third National Health and Nutrition Examination Survey, 1988-1994. Am J Clin } \\
\text { Nutr.2000;72:159-67. }\end{array}$ & Design, IV \\
\hline
\end{tabular}




\begin{tabular}{|c|c|c|}
\hline 250 & $\begin{array}{l}\text { Hegar, B.,Dewanti, N. R.,Kadim, M.,Alatas, S.,Firmansyah, A.,Vandenplas, Y. Natural evolution of regurgitation in healthy infants. } \\
\text { Acta Paediatr.2009;98:1189-93. }\end{array}$ & IV, DV \\
\hline 251 & $\begin{array}{l}\text { Heine, W.,Lapsien, C. Influence of early breast milk and formula feeding on body weight in children born in Rostock since } 1945 . \\
\text { Bibl Nutr Dieta.1982:17-8. }\end{array}$ & Design \\
\hline 252 & $\begin{array}{l}\text { Herbst, A.,Diethelm, K.,Cheng, G.,Alexy, U.,Icks, A.,Buyken, A. E. Direction of associations between added sugar intake in early } \\
\text { childhood and body mass index at age } 7 \text { years may depend on intake levels. J Nutr.2011;141:1348-54. }\end{array}$ & IV \\
\hline 253 & $\begin{array}{l}\text { Hess,S. Y.,Abbeddou,S.,Jimenez,E. Y.,Somé,J. W.,Vosti,S. A.,Ouédraogo,Z. P.,Guissou,R. M.,Ouédraogo,J. B.,Brown,K. H. } \\
\text { Small-quantity lipid-based nutrient supplements, regardless of their zinc content, increase growth and reduce the prevalence of } \\
\text { stunting and Wasting in young burkinabe children: A cluster-randomized trial. PLoS ONE.2015;10. }\end{array}$ & $\begin{array}{l}\text { IV, } \\
\text { Country }\end{array}$ \\
\hline 254 & $\begin{array}{l}\text { Hettiarachchi,M.,Lekamwasam,S.,Liyanage,C. Long-term cereal-based nutritional supplementation improved the total spine bone } \\
\text { mineral density amongst Sri Lankan preschool children: a randomized controlled study. J Pediatr Endocrinol Metab.2010;23:555- } \\
63 .\end{array}$ & IV, Age \\
\hline 255 & $\begin{array}{l}\text { Hijazi, S. S.,Abulaban, A.,Waterlow, J. C. The duration for which exclusive breast-feeding is adequate. A study in Jordan. Acta } \\
\text { Paediatr Scand.1989;78:23-8. }\end{array}$ & IV \\
\hline 256 & $\begin{array}{l}\text { Hillis, S. D.,Weigle, K.,Miranda, C. M.,McCann, M.,Bender, D.,Stewart, P. Supplementary feeding in Colombian child-care centers } \\
\text { and growth velocity. Pediatrics.1994;94:1066-9. }\end{array}$ & IV \\
\hline 257 & $\begin{array}{l}\text { Hitchcock, N. E.,Gracey, M.,Gilmour, A. I. The growth of breast fed and artificially fed infants from birth to twelve months. Acta } \\
\text { Paediatr Scand.1985;74:240-5. }\end{array}$ & IV \\
\hline 258 & $\begin{array}{l}\text { Hitchcock, N. E.,McGuiness, D.,Gracey, M. Growth and feeding practices of Western Australian infants. Med J Aust.1982;1:372- } \\
6 .\end{array}$ & $\begin{array}{l}\text { Design, IV, } \\
\text { DV, Date }\end{array}$ \\
\hline 259 & Hitchcock, N. E.,Owles, E. N.,Gracey, M. Breast feeding and growth of healthy infants. Med J Aust.1981;2:536-7. & $\begin{array}{l}\text { IV, DV, } \\
\text { Date }\end{array}$ \\
\hline 260 & $\begin{array}{l}\text { Hoffman, D. R.,Garfield, S.,Morale, S. E.,Bosworth, R. G.,Castaneda, Y. S.,Wheaton, D. K. H.,Theuer, R. C.,Birch, E. E. Visual } \\
\text { and neural development of breast-fed infants receiving docosahexaenoic acid (dha)-enriched baby food: a randomized clinical } \\
\text { trial. Iovs.2004;45:ARVO E-abstract } 3510 .\end{array}$ & Design \\
\hline 261 & $\begin{array}{l}\text { Hokama,T. Levels of serum ferritin and total body iron among infants with different feeding regimens. Acta Paediatr } \\
\text { Jpn.1993;35:298-301. }\end{array}$ & IV, DV \\
\hline 262 & $\begin{array}{l}\text { Holgerson PL,Vestman NR,Claesson R,Ohman C,Domellof M,Tanner AC,Hernell O,Johansson I. Oral microbial profile } \\
\text { discriminates breast-fed from formula-fed infants. J Pediatr Gastroenterol Nutr.2013;56:127-36. }\end{array}$ & $\begin{array}{l}\text { Design, IV, } \\
\text { DV }\end{array}$ \\
\hline 263 & $\begin{array}{l}\text { Hop le, T.,Berger, J. Multiple micronutrient supplementation improves anemia, micronutrient nutrient status, and growth of } \\
\text { Vietnamese infants: double-blind, randomized, placebo-controlled trial. J Nutr.2005;135:660s-665s. }\end{array}$ & IV \\
\hline 264 & $\begin{array}{l}\text { Hop, L. T.,Gross, R.,Giay, T.,Sastroamidjojo, S.,Schultink, W.,Lang, N. T. Premature complementary feeding is associated with } \\
\text { poorer growth of vietnamese children. J Nutr.2000;130:2683-90. }\end{array}$ & Country \\
\hline 265 & Hop, L. T.,Gross, R.,Giay, T.,Schultink, W.,Thuan, B. T.,Sastroamidjojo, S. Longitudinal observation of growth of Vietnamese & IV, DV \\
\hline
\end{tabular}




\begin{tabular}{|c|c|c|}
\hline & children in Hanoi, Vietnam from birth to 10 years of age. Eur J Clin Nutr.1997;51:164-71. & \\
\hline 266 & $\begin{array}{l}\text { Hopkins, D.,Steer, C. D.,Northstone, K.,Emmett, P. M. Effects on childhood body habitus of feeding large volumes of cow or } \\
\text { formula milk compared with breastfeeding in the latter part of infancy. Am J Clin Nutr.2015;102:1096-103. }\end{array}$ & IV \\
\hline 267 & $\begin{array}{l}\text { Hopkins,D.,Emmett,P.,Steer,C.,Rogers,I.,Noble,S.,Emond,A. Infant feeding in the second } 6 \text { months of life related to iron status: } \\
\text { an observational study. Arch Dis Child.2007;92:850-4. }\end{array}$ & DV \\
\hline 268 & $\begin{array}{l}\text { Hoppe, C., Molgaard, C.,Thomsen, B. L.,Juul, A.,Michaelsen, K. F. Protein intake at } 9 \text { mo of age is associated with body size but } \\
\text { not with body fat in 10-y-old Danish children. Am J Clin Nutr.2004;79:494-501. }\end{array}$ & IV \\
\hline 269 & $\begin{array}{l}\text { Horodynski, M. A.,Baker, S.,Van Egeren, L.,Olson, B.,Brophy-Herb, H.,Auld, G. The healthy babies curriculum. J Nutr Educ } \\
\text { Behav.2014;46:151-2. }\end{array}$ & Design, IV \\
\hline 270 & $\begin{array}{l}\text { Horta, B. L.,Bas, A.,Bhargava, S. K.,Fall, C. H.,Feranil, A.,de Kadt, J.,Martorell, R.,Richter, L. M.,Stein, A. D.,Victora, C. G. Infant } \\
\text { feeding and school attainment in five cohorts from low- and middle-income countries. PLoS One.2013;8:e71548. }\end{array}$ & Design \\
\hline 271 & Horwood, L. J.,Fergusson, D. M. Breastfeeding and later cognitive and academic outcomes. Pediatrics.1998;101:E9. & IV \\
\hline 272 & $\begin{array}{l}\text { Hosaka, M.,Asayama, K.,Staessen, J. A.,Ohkubo, T.,Hayashi, K.,Tatsuta, N.,Kurokawa, N.,Satoh, M.,Hashimoto, T.,Hirose, } \\
\text { T.,Obara, T.,Metoki, H.,Inoue, R.,Kikuya, M.,Nakai, K.,Imai, Y.,Satoh, H. Breastfeeding leads to lower blood pressure in 7-year- } \\
\text { old Japanese children: Tohoku Study of Child Development. Hypertens Res.2013;36:117-22. }\end{array}$ & IV, DV \\
\hline 273 & $\begin{array}{l}\text { Hudara S,Mimouni F,Rachman Y,Dayan B,Silbermintz A,Turner D. Retrospective cohort study of a new infant formula during the } \\
\text { first } 6 \text { months of life: reflections on growth curves, human milk and formula feeding. Isr Med Assoc J.2010;12:676-80. }\end{array}$ & IV \\
\hline 274 & $\begin{array}{l}\text { Hurley, K. M.,Black, M. M. Introduction to a supplement on responsive feeding: promoting healthy growth and development for } \\
\text { infants and toddlers. J Nutr.2011;141:489. }\end{array}$ & Design \\
\hline 275 & $\begin{array}{l}\text { Husaini, M. A.,Karyadi, L.,Husaini, Y. K.,Sandjaja,,Karyadi, D.,Pollitt, E. Developmental effects of short-term supplementary } \\
\text { feeding in nutritionally-at-risk Indonesian infants. Am J Clin Nutr.1991;54:799-804. }\end{array}$ & Country \\
\hline 276 & $\begin{array}{l}\text { Inostroza, J.,Haschke, F.,Steenhout, P.,Grathwohl, D.,Nelson, S. E.,Ziegler, E. E. Low-protein formula slows weight gain in } \\
\text { infants of overweight mothers. J Pediatr Gastroenterol Nutr.2014;59:70-7. }\end{array}$ & IV \\
\hline 277 & $\begin{array}{l}\text { Isherwood,R. J.,Dimond,C.,Longhurst,S. Breast feeding and weaning practices in relation to nutritional status of under-5 children } \\
\text { in north Bangladesh. J Trop Pediatr.1988;34:28-31. }\end{array}$ & Design \\
\hline 278 & $\begin{array}{l}\text { Islam, M. M.,Peerson, J. M.,Ahmed, T.,Dewey, K. G.,Brown, K. H. Effects of varied energy density of complementary foods on } \\
\text { breast-milk intakes and total energy consumption by healthy, breastfed Bangladeshi children. Am J Clin Nutr.2006;83:851-8. }\end{array}$ & IV, DV \\
\hline 279 & $\begin{array}{l}\text { Jackson, D. A.,Imong, S. M.,Wongsawasdii, L.,Silprasert, A.,Preunglampoo, S.,Leelapat, P.,Drewett, R. F.,Amatayakul, K.,Baum, } \\
\text { J. D. Weaning practices and breast-feeding duration in Northern Thailand. Br J Nutr.1992;67:149-64. }\end{array}$ & IV, DV \\
\hline 280 & $\begin{array}{l}\text { Jackson,M. I. Early childhood WIC participation, cognitive development and academic achievement. Soc Sci Med.2015;126:145- } \\
\text { 53. }\end{array}$ & IV \\
\hline 281 & $\begin{array}{l}\text { Jacobson, S. W.,Chiodo, L. M.,Jacobson, J. L. Breastfeeding effects on intelligence quotient in 4- and 11-year-old children. } \\
\text { Pediatrics.1999;103:e71. }\end{array}$ & IV \\
\hline
\end{tabular}




\begin{tabular}{|c|c|c|}
\hline 282 & $\begin{array}{l}\text { Jain,V.,Klein,B. P.,Nash,M.,Chapman-Novakofski,K. Two feasibility studies for introduction of multimicronutrient soy/whey-based } \\
\text { supplements in rural homes in Honduras. Journal of Hunger and Environmental Nutrition.2011;6:247-263. }\end{array}$ & IV \\
\hline 283 & Jansen,G.R.,O'B Hourihane. The nutritional status of preschool children in Egypt. World Rev Nutr Diet.1985;45:42-67. & Design \\
\hline 284 & $\begin{array}{l}\text { Jatanasen,A.,Sacholvicharn,V.,Ongkulna,P. An evaluation of supplementary feedings of Thai infants in urban slum communities: } \\
\text { effect on growth, health and nutritional status. J Med Assoc Thai.1983;66 Suppl 1:20-9. }\end{array}$ & $\begin{array}{l}\text { Design, } \\
\text { Health } \\
\text { status }\end{array}$ \\
\hline 285 & $\begin{array}{l}\text { Jensen, B. W.,Nichols, M.,Allender, S.,de Silva-Sanigorski, A.,Millar, L.,Kremer, P.,Lacy, K.,Swinburn, B. Inconsistent } \\
\text { associations between sweet drink intake and 2-year change in BMI among Victorian children and adolescents. Pediatr } \\
\text { Obes.2013;8:271-83. }\end{array}$ & Age \\
\hline 286 & $\begin{array}{l}\text { Jensen, S. M.,Ritz, C.,Ejlerskov, K. T.,Molgaard, C.,Michaelsen, K. F. Infant BMI peak, breastfeeding, and body composition at } \\
\text { age } 3 \text { y. Am J Clin Nutr.2015;101:319-25. }\end{array}$ & IV \\
\hline 287 & $\begin{array}{l}\text { Jensen,C. L.,Prager,T. C.,Zou,Y.,Fraley,J. K.,Maude,M.,Anderson,R. E.,Heird,W. C. Effects of maternal docosahexaenoic acid } \\
\text { supplementation on visual function and growth of breast-fed term infants. Lipids.1999;34 Suppl:S225. }\end{array}$ & Design, IV \\
\hline 288 & $\begin{array}{l}\text { Jones, G.,Hynes, K. L.,Dwyer, T. The association between breastfeeding, maternal smoking in utero, and birth weight with bone } \\
\text { mass and fractures in adolescents: a 16-year longitudinal study. Osteoporos Int.2013;24:1605-11. }\end{array}$ & IV \\
\hline 289 & $\begin{array}{l}\text { Jones, G.,Riley, M.,Dwyer, T. Breastfeeding in early life and bone mass in prepubertal children: a longitudinal study. Osteoporos } \\
\text { Int.2000;11:146-52. }\end{array}$ & IV \\
\hline 290 & $\begin{array}{l}\text { Jooste, P. L.,Rossouw, L. J.,Steenkamp, H. J.,Rossouw, J. E.,Swanepoel, A. S.,Charlton, D. O. Effect of breast feeding on the } \\
\text { plasma cholesterol and growth of infants. J Pediatr Gastroenterol Nutr.1991;13:139-42. }\end{array}$ & IV \\
\hline 291 & $\begin{array}{l}\text { Joseph, N.,Unnikrishnan, B.,Naik, V. A.,Mahantshetti, N. S.,Mallapur, M. D.,Kotian, S. M.,Nelliyanil, M. Infant rearing practices in } \\
\text { South India: a longitudinal study. J Family Med Prim Care.2013;2:37-43. }\end{array}$ & Country \\
\hline 292 & $\begin{array}{l}\text { Joshi N,Agho KE,Dibley MJ,Senarath U,Tiwari K. Determinants of inappropriate complementary feeding practices in young } \\
\text { children in Nepal: secondary data analysis of Demographic and Health Survey 2006. Matern Child Nutr.2012;8 Suppl 1:45-59. }\end{array}$ & $\begin{array}{l}\text { Design, } \\
\text { Country }\end{array}$ \\
\hline 293 & $\begin{array}{l}\text { Juez, G.,Diaz, S.,Casado, M. E.,Duran, E.,Salvatierra, A. M.,Peralta, O.,Croxatto, H. B. Growth pattern of selected urban Chilean } \\
\text { infants during exclusive breast-feeding. Am J Clin Nutr.1983;38:462-8. }\end{array}$ & IV \\
\hline 294 & $\begin{array}{l}\text { Jung, E.,Czajka-Narins, D. M. Birth weight doubling and tripling times: an updated look at the effects of birth weight, sex, race and } \\
\text { type of feeding. Am J Clin Nutr.1985;42:182-9. }\end{array}$ & IV \\
\hline 295 & $\begin{array}{l}\text { Kagura, J.,Feeley, A. B.,Micklesfield, L. K.,Pettifor, J. M.,Norris, S. A. Association between infant nutrition and anthropometry, } \\
\text { and pre-pubertal body composition in urban South African children. J Dev Orig Health Dis.2012;3:415-23. }\end{array}$ & Country \\
\hline 296 & $\begin{array}{l}\text { Kainonen E,Rautava S,Isolauri E. Immunological programming by breast milk creates an anti-inflammatory cytokine milieu in } \\
\text { breast-fed infants compared to formula-fed infants. Br J Nutr.2013;109:1962-70. }\end{array}$ & IV, DV \\
\hline 297 & $\begin{array}{l}\text { Kajantie, E.,Barker, D. J.,Osmond, C., Forsen, T.,Eriksson, J. G. Growth before } 2 \text { years of age and serum lipids } 60 \text { years later: the } \\
\text { Helsinki Birth Cohort study. Int J Epidemiol.2008;37:280-9. }\end{array}$ & DV \\
\hline
\end{tabular}




\begin{tabular}{|c|c|c|}
\hline 298 & $\begin{array}{l}\text { Kallio, M. J.,Salmenpera, L.,Siimes, M. A.,Perheentupa, J.,Miettinen, T. A. Tracking of serum cholesterol and lipoprotein levels } \\
\text { from the first year of life. Pediatrics.1993;91:949-54. }\end{array}$ & IV, DV \\
\hline 299 & $\begin{array}{l}\text { Kallio,M. J.,Salmenpera,L.,Siimes,M. A.,Perheentupa,J.,Miettinen,T. A. Exclusive breast-feeding and weaning: effect on serum } \\
\text { cholesterol and lipoprotein concentrations in infants during the first year of life. Pediatrics.1992;89:663-6. }\end{array}$ & IV, DV \\
\hline 300 & $\begin{array}{l}\text { Karaolis-Danckert, N.,Buyken, A. E.,Kulig, M.,Kroke, A.,Forster, J.,Kamin, W.,Schuster, A.,Hornberg, C.,Keil, T.,Bergmann, R. } \\
\text { L.,Wahn, U.,Lau, S. How pre- and postnatal risk factors modify the effect of rapid weight gain in infancy and early childhood on } \\
\text { subsequent fat mass development: results from the Multicenter Allergy Study 90. Am J Clin Nutr.2008;87:1356-64. }\end{array}$ & IV \\
\hline 301 & $\begin{array}{l}\text { Karlsland Akeson, P. K.,Axelsson, I. E.,Raiha, N. C.,Warm, A.,Minoli, I.,Moro, G. Protein intake and metabolism in formula-fed } \\
\text { infants given Swedish or Italian weaning foods. Acta Paediatr.2000;89:158-64. }\end{array}$ & IV \\
\hline 302 & $\begin{array}{l}\text { Karlsson Videhult, F.,Ohlund, I.,Stenlund, H.,Hernell, O.,West, C. E. Probiotics during weaning: a follow-up study on effects on } \\
\text { body composition and metabolic markers at school age. Eur J Nutr.2015;54:355-63. }\end{array}$ & IV \\
\hline 303 & $\begin{array}{l}\text { Kattelmann,K. K.,Ho,M.,Specker,B. L. Effect of timing of introduction of complementary foods on iron and zinc status of formula } \\
\text { fed infants at 12, 24, and } 36 \text { months of age. J Am Diet Assoc.2001;101:443-7. }\end{array}$ & DV \\
\hline 304 & $\begin{array}{l}\text { Kavanagh, K. F.,Cohen, R. J.,Heinig, M. J.,Dewey, K. G. Educational intervention to modify bottle-feeding behaviors among } \\
\text { formula-feeding mothers in the WIC program: impact on infant formula intake and weight gain. J Nutr Educ Behav.2008;40:244- } \\
50 .\end{array}$ & IV \\
\hline 305 & $\begin{array}{l}\text { Kavle, J. A.,Flax, V. L.,Abdelmegeid, A.,Salah, F.,Hafez, S.,Ramzy, M.,Hamed, D.,Saleh, G.,Galloway, R. Factors associated } \\
\text { with early growth in Egyptian infants: implications for addressing the dual burden of malnutrition. Matern Child Nutr.2016;12:139- } \\
51 .\end{array}$ & Country \\
\hline 306 & $\begin{array}{l}\text { Kersting, M.,Alexy, U.,Sichert-Hellert, W.,Manz, F.,Schoch, G. Measured consumption of commercial infant food products in } \\
\text { German infants: results from the DONALD study. Dortmund Nutritional and Anthropometrical Longitudinally Designed. J Pediatr } \\
\text { Gastroenterol Nutr.1998;27:547-52. }\end{array}$ & DV \\
\hline 307 & $\begin{array}{l}\text { Kesaree, N.,Shivamurty, K. S.,Prakash, B. S.,Ramachandra,,Haridas, C. K. Feeding pattern of infants in Devangere. Indian J } \\
\text { Pediatr.1981;48:281-4. }\end{array}$ & Design, IV \\
\hline 308 & Khaldi, F.,Bouguerra, F. Feeding practices, growth, and morbidity in Tunisia. Pediatrics.2000;106:1275-6. & $\begin{array}{l}\text { Design, } \\
\text { Date }\end{array}$ \\
\hline 309 & $\begin{array}{l}\text { Khan, A. I.,Kabir, I.,Hawkesworth, S.,Ekström, E. C.,Arifeen, S.,Frongillo, E. A.,Persson, L. A. Early invitation to food and/or } \\
\text { multiple micronutrient supplementation in pregnancy does not affect body composition in offspring at } 54 \text { months: Follow-up of the } \\
\text { MINIMat randomised trial, Bangladesh. Maternal and Child Nutrition.2015;11:385-397. }\end{array}$ & IV, Age \\
\hline 310 & Khan, M. U. Breastfeeding, growth and diarrhoea in rural Bangladesh children. Hum Nutr Clin Nutr.1984;38:113-9. & IV \\
\hline 311 & Khan, M. Infant feeding practices in rural Meheran, Comilla, Bangladesh. Am J Clin Nutr.1980;33:2356-64. & IV, DV \\
\hline 312 & $\begin{array}{l}\text { Kholdi N,Zayeri F,Bagheban AA,Khodakarim S,Ramezankhani A. A study of growth failure and its related factors in children from } \\
0 \text { to } 2 \text { years in Tehran, Iran. Turk J Pediatr.2012;54:38-44. }\end{array}$ & Design \\
\hline
\end{tabular}




\begin{tabular}{|c|c|c|}
\hline 313 & $\begin{array}{l}\text { Kiefte-de Jong, J. C., de Vries, J. H.,Escher, J. C., Jaddoe, V. W.,Hofman, A., Raat, H.,Moll, H. A. Role of dietary patterns, } \\
\text { sedentary behaviour and overweight on the longitudinal development of childhood constipation: the Generation R study. Matern } \\
\text { Child Nutr.2013;9:511-23. }\end{array}$ & DV \\
\hline 314 & $\begin{array}{l}\text { Kilaru, A.,Griffiths, P. L.,Ganapathy, S.,Ghosh, S. Community-based nutrition education for improving infant growth in rural } \\
\text { Karnataka. Indian Pediatr.2005;42:425-32. }\end{array}$ & IV \\
\hline 315 & $\begin{array}{l}\text { King,S.,Prawitz,A. D.,Umoren,J.,O'Gorman,T. The impact of high diastase malted barley flour on weight and height of } \\
\text { malnourished children in Panama. Journal of Hunger and Environmental Nutrition.2007;1:23-35. }\end{array}$ & $\begin{array}{l}\text { Health } \\
\text { status, } \\
\text { Age }\end{array}$ \\
\hline 316 & $\begin{array}{l}\text { Klag, E. A.,McNamara, K., Geraghty, S. R.,Keim, S. A. Associations Between Breast Milk Feeding, Introduction of Solid Foods, } \\
\text { and Weight Gain in the First } 12 \text { Months of Life. Clin Pediatr (Phila).2015;54:1059-67. }\end{array}$ & Design \\
\hline 317 & Kleinman, R. E. Complementary feeding and neuromuscular development. Pediatrics.2000;106:1279. & Design \\
\hline 318 & $\begin{array}{l}\text { Kolacek, S.,Kapetanovic, T.,Zimolo, A.,Luzar, V. Early determinants of cardiovascular risk factors in adults. A. Plasma lipids. } \\
\text { Acta Paediatr.1993;82:699-704. }\end{array}$ & DV \\
\hline 319 & $\begin{array}{l}\text { Koletzko, B.,Dokoupil, K.,Reitmayr, S.,Weimert-Harendza, B.,Keller, E. Dietary fat intakes in infants and primary school children } \\
\text { in Germany. Am J Clin Nutr.2000;72:1392s-1398s. }\end{array}$ & IV, DV \\
\hline 320 & $\begin{array}{l}\text { Koletzko, B.,von Kries, R.,Closa, R.,Escribano, J.,Scaglioni, S.,Giovannini, M.,Beyer, J.,Demmelmair, H.,Anton, B.,Gruszfeld, } \\
\text { D.,Dobrzanska, A.,Sengier, A.,Langhendries, J. P.,Rolland Cachera, M. F.,Grote, V. Can infant feeding choices modulate later } \\
\text { obesity risk?. Am J Clin Nutr.2009;89:1502s-1508s. }\end{array}$ & Design, IV \\
\hline 321 & $\begin{array}{l}\text { Koletzko, B.,von Kries, R.,Closa, R.,Escribano, J.,Scaglioni, S., Giovannini, M.,Beyer, J.,Demmelmair, H.,Gruszfeld, } \\
\text { D.,Dobrzanska, A., Sengier, A.,Langhendries, J. P.,Rolland Cachera, M. F., Grote, V. Lower protein in infant formula is associated } \\
\text { with lower weight up to age } 2 \text { y: a randomized clinical trial. Am J Clin Nutr.2009;89:1836-45. }\end{array}$ & IV \\
\hline 322 & Koletzko, B. Complementary foods and the development of food allergy. Pediatrics.2000;106:1285. & Design \\
\hline 323 & $\begin{array}{l}\text { Konstantynowicz, J.,Nguyen, T. V.,Kaczmarski, M.,Jamiolkowski, J.,Piotrowska-Jastrzebska, J.,Seeman, E. Fractures during } \\
\text { growth: potential role of a milk-free diet. Osteoporos Int.2007;18:1601-7. }\end{array}$ & Age \\
\hline 324 & $\begin{array}{l}\text { Kramer, M. S.,Fombonne, E.,Matush, L.,Bogdanovich, N.,Dahhou, M.,Platt, R. W. Long-term behavioural consequences of infant } \\
\text { feeding: the limits of observational studies. Paediatr Perinat Epidemiol.2011;25:500-6. }\end{array}$ & IV \\
\hline 325 & $\begin{array}{l}\text { Kramer, M. S.,Guo, T.,Platt, R. W.,Shapiro, S.,Collet, J. P.,Chalmers, B.,Hodnett, E.,Sevkovskaya, Z.,Dzikovich, I.,Vanilovich, I. } \\
\text { Breastfeeding and infant growth: biology or bias?. Pediatrics.2002;110:343-7. }\end{array}$ & IV \\
\hline 326 & $\begin{array}{l}\text { Kramer, M. S.,Moodie, E. E.,Dahhou, M.,Platt, R. W. Breastfeeding and infant size: evidence of reverse causality. Am J } \\
\text { Epidemiol.2011;173:978-83. }\end{array}$ & IV, DV \\
\hline 327 & $\begin{array}{l}\text { Kramer, M. S.,Moodie, E. E.,Platt, R. W. Infant feeding and growth: can we answer the causal question?. } \\
\text { Epidemiology.2012;23:790-4. }\end{array}$ & Design \\
\hline 328 & Kramer, M. S. Do breast-feeding and delayed introduction of solid foods protect against subsequent obesity?. J & Design \\
\hline
\end{tabular}




\begin{tabular}{|c|c|c|}
\hline & Pediatr.1981;98:883-7. & \\
\hline 329 & $\begin{array}{l}\text { Krebs,N. F. Culbertson D. L. Westcott J. L. Sherlock L. Hambidge K. M. Normal Iron Status in Breastfed Infants Consuming Meat } \\
\text { as an Early Complementary Food. Pediatric Academic Societies Annual Meeting.2011. }\end{array}$ & Design \\
\hline 330 & $\begin{array}{l}\text { Krebs,N. F.,Hambidge,K. M.,Westcott,J. E.,Miller,L. V.,Sian,L.,Bell,M.,Grunwald,G. Exchangeable zinc pool size in infants is } \\
\text { related to key variables of zinc homeostasis. J Nutr.2003;133:1498s-501s. }\end{array}$ & DV \\
\hline 331 & $\begin{array}{l}\text { Krebs,N. F.,Mazariegos,M.,Chomba,E.,Sami,N.,Pasha,O.,Tshefu,A.,Carlo,W. A.,Goldenberg,R. L.,Bose,C. L.,Wright,L. L.,Koso- } \\
\text { Thomas,M.,Goco,N.,Kindem,M.,McClure,E. M.,Westcott,J.,Garces,A.,Lokangaka,A.,Manasyan,A.,Imenda,E.,Hartwell,T. } \\
\text { D.,Hambidge,K. M. Randomized controlled trial of meat compared with multimicronutrient-fortified cereal in infants and toddlers } \\
\text { with high stunting rates in diverse settings. Am J Clin Nutr.2012;96:840-7. }\end{array}$ & Country \\
\hline 332 & $\begin{array}{l}\text { Krebs,N. F.,Westcott,J. E.,Culbertson,D. L.,Sian,L.,Miller,L. V.,Hambidge,K. M. Comparison of complementary feeding strategies } \\
\text { to meet zinc requirements of older breastfed infants. Am J Clin Nutr.2012;96:30-5. }\end{array}$ & DV \\
\hline 333 & $\begin{array}{l}\text { Kronborg, H.,Foverskov, E.,Vaeth, M. Predictors for early introduction of solid food among Danish mothers and infants: an } \\
\text { observational study. BMC Pediatr.2014;14:243. }\end{array}$ & $\begin{array}{l}\text { Design, } \\
\text { DV }\end{array}$ \\
\hline 334 & $\begin{array}{l}\text { Kuklina, E. V.,Ramakrishnan, U.,Stein, A. D.,Barnhart, H. H.,Martorell, R. Growth and diet quality are associated with the } \\
\text { attainment of walking in rural Guatemalan infants. J Nutr.2004;134:3296-300. }\end{array}$ & IV \\
\hline 335 & $\begin{array}{l}\text { Kumar, V.,Sharma, S.,Khanna, P.,Vanaja, K. Breast vs bottle feeding-impact on growth in urban infants. Indian J } \\
\text { Pediatr.1981;48:271-5. }\end{array}$ & IV, DV \\
\hline 336 & $\begin{array}{l}\text { Kusin, J. A., Kardjati, S.,van Steenbergen, W. M.,Renqvist, U. H. Nutritional transition during infancy in East Java, Indonesia: } 2 \text {. A } \\
\text { longitudinal study of growth in relation to the intake of breast milk and additional foods. Eur J Clin Nutr.1991;45:77-84. }\end{array}$ & IV \\
\hline 337 & Kusin, J. A.,Kardjati, S.,van Steenbergen, W. Traditional infant feeding practices: right or wrong?. Soc Sci Med.1985;21:283-6. & $\begin{array}{l}\text { IV, } \\
\text { Country }\end{array}$ \\
\hline 338 & $\begin{array}{l}\text { Kwok, M. K.,Leung, G. M.,Lam, T. H.,Schooling, C. M. Breastfeeding, childhood milk consumption, and onset of puberty. } \\
\text { Pediatrics.2012;130:e631-9. }\end{array}$ & DV \\
\hline 339 & $\begin{array}{l}\text { Laitinen,K.,Kalliomaki,M.,Poussa,T.,Lagstrom,H.,Isolauri,E. Evaluation of diet and growth in children with and without atopic } \\
\text { eczema: follow-up study from birth to } 4 \text { years. Br J Nutr.2005;94:565-74. }\end{array}$ & IV, DV \\
\hline 340 & $\begin{array}{l}\text { Lampe,J. B.,Velez,N. The effect of prolonged bottle feeding on cow's milk intake and iron stores at } 18 \text { months of age. Clin } \\
\text { Pediatr (Phila).1997;36:569-72. }\end{array}$ & Design \\
\hline 341 & Lang B,Moynihan P. The weaning diet: promoting growth while safeguarding dental health. Quintessence Int.2006;37:632-6. & Design \\
\hline 342 & $\begin{array}{l}\text { Larnkjaer, A.,Hoppe, C., Molgaard, C.,Michaelsen, K. F. The effects of whole milk and infant formula on growth and IGF-I in late } \\
\text { infancy. Eur J Clin Nutr.2009;63:956-63. }\end{array}$ & IV \\
\hline 343 & $\begin{array}{l}\text { Lasky, P. A., Eichelberger, K. M. Implications, considerations, and nursing interventions of obesity in neonatal and preschool } \\
\text { patients. Nurs Clin North Am.1982;17:199-205. }\end{array}$ & Design \\
\hline
\end{tabular}




\begin{tabular}{|c|c|c|}
\hline 344 & $\begin{array}{l}\text { Lauzon-Guillain, Bd,Wijndaele, K.,Clark, M.,Acerini, C. L.,Hughes, I. A.,Dunger, D. B.,Wells, J. C., Ong, K. K. Breastfeeding and } \\
\text { infant temperament at age three months. PLoS One.2012;7:e29326. }\end{array}$ & Design, IV \\
\hline 345 & $\begin{array}{l}\text { Lawlor, D. A.,Riddoch, C. J.,Page, A. S.,Andersen, L. B.,Wedderkopp, N.,Harro, M.,Stansbie, D.,Smith, G. D. Infant feeding and } \\
\text { components of the metabolic syndrome: findings from the European Youth Heart Study. Arch Dis Child.2005;90:582-8. }\end{array}$ & IV \\
\hline 346 & Lee, K. Crying and behavior pattern in breast- and formula-fed infants. Early Hum Dev.2000;58:133-40. & $\begin{array}{l}\text { Design, IV, } \\
\text { DV }\end{array}$ \\
\hline 347 & $\begin{array}{l}\text { Leermakers, E. T.,Kiefte-de Jong, J. C.,Hofman, A.,Jaddoe, V. W.,Franco, O. H. Lutein intake at the age of } 1 \text { year and } \\
\text { cardiometabolic health at the age of } 6 \text { years: the Generation R Study. Br J Nutr.2015;114:970-8. }\end{array}$ & IV \\
\hline 348 & Legovic, M.,Ostric, L. The effects of feeding methods on the growth of the jaws in infants. ASDC J Dent Child.1991;58:253-5. & $\begin{array}{l}\text { Design, IV, } \\
\text { DV }\end{array}$ \\
\hline 349 & $\begin{array}{l}\text { Lei, D. L.,Chaves, S. P.,Paes, A. T.,Escuder, M. M.,Ribeiro, A. B.,Freire, R. D.,Lerner, B. R. Risk of linear growth retardation } \\
\text { during the first two years of life: a new approach. Eur J Clin Nutr.1999;53:456-60. }\end{array}$ & IV \\
\hline 350 & $\begin{array}{l}\text { Leonard, W. R.,Dewalt, K. M.,Stansbury, J. P.,McCaston, M. K. Influence of dietary quality on the growth of highland and coastal } \\
\text { Ecuadorian children. Am J Hum Biol.2000;12:825-837. }\end{array}$ & IV \\
\hline 351 & $\begin{array}{l}\text { Leroy, J. L.,Ruel, M.,Habicht, J. P.,Frongillo, E. A. Using height-for-age differences (HAD) instead of height-for-age z-scores } \\
\text { (HAZ) for the meaningful measurement of population-level catch-up in linear growth in children less than } 5 \text { years of age. BMC } \\
\text { Pediatr.2015;15:145. }\end{array}$ & IV \\
\hline 352 & $\begin{array}{l}\text { Leung, S. S.,Peng, C. X.,Xu, Y. Y.,Liu, K. M.,Quan, X. J.,Lui, S.,Davies, D. P. Comparative study of growth of Chinese infants: } \\
\text { Hong Kong versus Guangzhou. J Trop Pediatr.1994;40:166-71. }\end{array}$ & IV, DV \\
\hline 353 & Leung,S.,Davies,D. P. Infant feeding and growth of Chinese infants: birth to 2 years. Paediatr Perinat Epidemiol.1994;8:301-13. & IV, DV \\
\hline 354 & $\begin{array}{l}\text { Leventakou, V.,Roumeliotaki, T.,Koutra, K.,Vassilaki, M.,Mantzouranis, E.,Bitsios, P.,Kogevinas, M.,Chatzi, L. Breastfeeding } \\
\text { duration and cognitive, language and motor development at } 18 \text { months of age: Rhea mother-child cohort in Crete, Greece. J } \\
\text { Epidemiol Community Health.2015;69:232-9. }\end{array}$ & IV \\
\hline 355 & $\begin{array}{l}\text { Li, C.,Kaur, H.,Choi, W. S.,Huang, T. T.,Lee, R. E.,Ahluwalia, J. S. Additive interactions of maternal prepregnancy BMI and } \\
\text { breast-feeding on childhood overweight. Obes Res.2005;13:362-71. }\end{array}$ & IV \\
\hline 356 & $\begin{array}{l}\text { Li, R.,Magadia, J.,Fein, S. B.,Grummer-Strawn, L. M. Risk of bottle-feeding for rapid weight gain during the first year of life. Arch } \\
\text { Pediatr Adolesc Med.2012;166:431-6. }\end{array}$ & IV \\
\hline 357 & $\begin{array}{l}\text { Lin, S. L.,Leung, G. M.,Lam, T. H.,Schooling, C. M. Timing of solid food introduction and obesity: Hong Kong's "children of 1997" } \\
\text { birth cohort. Pediatrics.2013;131:e1459-67. }\end{array}$ & Design \\
\hline 358 & $\begin{array}{l}\text { Lind,T.,Lonnerdal,B.,Persson,L. A.,Stenlund,H.,Tennefors,C.,Hernell,O. Effects of weaning cereals with different phytate contents } \\
\text { on hemoglobin, iron stores, and serum zinc: a randomized intervention in infants from } 6 \text { to } 12 \text { mo of age. Am J Clin } \\
\text { Nutr.2003;78:168-75. }\end{array}$ & DV \\
\hline 359 & Livingstone V. Failure to thrive while breastfeeding. Breastfeed Med.2006;1:108-11. & Design \\
\hline
\end{tabular}




\begin{tabular}{|c|c|c|}
\hline 360 & $\begin{array}{l}\text { Lozoff, B.,De Andraca, I.,Castillo, M.,Smith, J. B.,Walter, T.,Pino, P. Behavioral and developmental effects of preventing iron- } \\
\text { deficiency anemia in healthy full-term infants. Pediatrics.2003;112:846-54. }\end{array}$ & IV \\
\hline 361 & $\begin{array}{l}\text { Lucas, R.,Judge, M.,Sajdlowska, J.,Cong, X.,McGrath, J. M.,Brandon, D. Effect of Maternal Body Mass Index on Infant } \\
\text { Breastfeeding Behaviors and Exclusive Direct Breastfeeding. J Obstet Gynecol Neonatal Nurs.2015;44:772-83. }\end{array}$ & DV \\
\hline 362 & $\begin{array}{l}\text { Lutter, C. K.,Mora, J. O.,Habicht, J. P.,Rasmussen, K. M.,Robson, D. S.,Herrera, M. G. Age-specific responsiveness of weight } \\
\text { and length to nutritional supplementation. Am J Clin Nutr.1990;51:359-64. }\end{array}$ & IV \\
\hline 363 & $\begin{array}{l}\text { Lutter, C. K.,Mora, J. O.,Habicht, J. P.,Rasmussen, K. M.,Robson, D. S.,Sellers, S. G.,Super, C. M.,Herrera, M. G. Nutritional } \\
\text { supplementation: effects on child stunting because of diarrhea. Am J Clin Nutr.1989;50:1-8. }\end{array}$ & IV \\
\hline 364 & $\begin{array}{l}\text { Lutter,C. K.,Rodriguez,A.,Fuenmayor,G.,Avila,L.,Sempertegui,F.,Escobar,J. Growth and micronutrient status in children receiving } \\
\text { a fortified complementary food. J Nutr.2008;138:379-88. }\end{array}$ & IV \\
\hline 365 & $\begin{array}{l}\text { Luukkainen,P.,Salo,M. K.,Visakorpi,J. K.,Raiha,N. C.,Nikkari,T. Impact of solid food on plasma arachidonic and docosahexaenoic } \\
\text { acid status of term infants at } 8 \text { months of age. J Pediatr Gastroenterol Nutr.1996;23:229-34. }\end{array}$ & IV, DV \\
\hline 366 & MacCarthy, D. Psychological influences affecting growth. Health Visit.1980;53:470-6. & Design \\
\hline 367 & $\begin{array}{l}\text { Magarey, A.,Kavian, F.,Scott, J. A.,Markow, K.,Daniels, L. Feeding Mode of Australian Infants in the First } 12 \text { Months of Life: An } \\
\text { Assessment against National Breastfeeding Indicators. J Hum Lact.2015. }\end{array}$ & DV \\
\hline 368 & $\begin{array}{l}\text { Maimaitiming, T.,Wang, Y. P. Feeding and intellectual development in infants and children from Uygur, Kazak, and Han } \\
\text { nationality: A comparison of } 454 \text { cases. Journal of Clinical Rehabilitative Tissue Engineering Research.2007;11:10710-10712. }\end{array}$ & Design \\
\hline 369 & $\begin{array}{l}\text { Makrides,M.,Gould,J. F.,Gawlik,N. R.,Yelland,L. N.,Smithers,L. G.,Anderson,P. J.,Gibson,R. A. Four-year follow-up of children } \\
\text { born to women in a randomized trial of prenatal DHA supplementation. Jama.2014;311:1802-4. }\end{array}$ & IV \\
\hline 370 & $\begin{array}{l}\text { Male,C.,Persson,L. A.,Freeman,V.,Guerra,A.,van't Hof,M. A.,Haschke,F. Prevalence of iron deficiency in 12-mo-old infants from } \\
11 \text { European areas and influence of dietary factors on iron status (Euro-Growth study). Acta Paediatr.2001;90:492-8. }\end{array}$ & DV \\
\hline 371 & $\begin{array}{l}\text { Mallan, K. M.,Fildes, A.,Magarey, A. M.,Daniels, L. A. The Relationship between Number of Fruits, Vegetables, and Noncore } \\
\text { Foods Tried at Age } 14 \text { Months and Food Preferences, Dietary Intake Patterns, Fussy Eating Behavior, and Weight Status at Age } \\
\text { 3.7 Years. J Acad Nutr Diet.2016;116:630-7. }\end{array}$ & DV \\
\hline 372 & $\begin{array}{l}\text { Mallard,S. R.,Houghton,L. A.,Filteau,S.,Mullen,A.,Nieuwelink,J.,Chisenga,M.,Siame,J.,Gibson,R. S. Dietary diversity at } 6 \text { months } \\
\text { of age is associated with subsequent growth and mediates the effect of maternal education on infant growth in urban Zambia. J } \\
\text { Nutr.2014;144:1818-25. }\end{array}$ & Country \\
\hline 373 & $\begin{array}{l}\text { Mamabolo, R. L.,Alberts, M.,Mbenyane, G. X.,Steyn, N. P.,Nthangeni, N. G.,Delemarre-Van De Waal, H. A.,Levitt, N. S. Feeding } \\
\text { practices and growth of infants from birth to } 12 \text { months in the central region of the Limpopo Province of South Africa. } \\
\text { Nutrition.2004;20:327-33. }\end{array}$ & IV, DV \\
\hline 374 & $\begin{array}{l}\text { Mamabolo,R. L.,Alberts,M.,Levitt,N. S.,Delemarre-van de Waal,H. A.,Steyn,N. P. Association between insulin-like growth factor-1, } \\
\text { insulin-like growth factor-binding protein-1 and leptin levels with nutritional status in 1-3-year-old children, residing in the central } \\
\text { region of Limpopo Province, South Africa. Br J Nutr.2007;98:762-9. }\end{array}$ & IV \\
\hline
\end{tabular}




\begin{tabular}{|c|c|c|}
\hline 375 & $\begin{array}{l}\text { Mamun, A. A.,Lawlor, D. A.,O'Callaghan, M. J.,Williams, G. M.,Najman, J. M. Family and early life factors associated with } \\
\text { changes in overweight status between ages } 5 \text { and } 14 \text { years: findings from the Mater University Study of Pregnancy and its } \\
\text { outcomes. Int J Obes (Lond).2005;29:475-82. }\end{array}$ & IV \\
\hline 376 & $\begin{array}{l}\text { Manjrekar, C.,Vishalakshi, M. P.,Begum, N. J.,Padma, G. N. Breast feeding ability of undernourished mothers and physical } \\
\text { development of their infants during 0-1 year. Indian Pediatr.1985;22:801-9. }\end{array}$ & IV, DV \\
\hline 377 & $\begin{array}{l}\text { Marques,R. C.,Dorea,J. G.,Bernardi,J. V.,Bastos,W. R.,Malm,O. Maternal fish consumption in the nutrition transition of the } \\
\text { Amazon Basin: growth of exclusively breastfed infants during the first } 5 \text { years. Ann Hum Biol.2008;35:363-77. }\end{array}$ & IV \\
\hline 378 & $\begin{array}{l}\text { Marquis, G. S.,Habicht, J. P.,Lanata, C. F.,Black, R. E.,Rasmussen, K. M. Association of breastfeeding and stunting in Peruvian } \\
\text { toddlers: an example of reverse causality. Int J Epidemiol.1997;26:349-56. }\end{array}$ & Design \\
\hline 379 & $\begin{array}{l}\text { Marquis, G. S.,Habicht, J. P.,Lanata, C. F.,Black, R. E.,Rasmussen, K. M. Breast milk or animal-product foods improve linear } \\
\text { growth of Peruvian toddlers consuming marginal diets. Am J Clin Nutr.1997;66:1102-9. }\end{array}$ & Design \\
\hline 380 & $\begin{array}{l}\text { Martin, R. M.,McCarthy, A.,Smith, G. D.,Davies, D. P.,Ben-Shlomo, Y. Infant nutrition and blood pressure in early adulthood: the } \\
\text { Barry Caerphilly Growth study. Am J Clin Nutr.2003;77:1489-97. }\end{array}$ & IV, DV \\
\hline 381 & $\begin{array}{l}\text { Martin, R. M.,Smith, G. D.,Mangtani, P.,Frankel, S.,Gunnell, D. Association between breast feeding and growth: the Boyd-Orr } \\
\text { cohort study. Arch Dis Child Fetal Neonatal Ed.2002;87:F193-201. }\end{array}$ & IV \\
\hline 382 & $\begin{array}{l}\text { Martines, J. C.,Habicht, J. P.,Ashworth, A.,Kirkwood, B. R. Weaning in southern Brazil: is there a "weanling's dilemma"?. J } \\
\text { Nutr.1994;124:1189-98. }\end{array}$ & IV \\
\hline 383 & $\begin{array}{l}\text { Matsuzaki,M.,Kuper,H.,Kulkarni,B.,Radhakrishna,K. V.,Viljakainen,H.,Taylor,A. E.,Sullivan,R.,Bowen,L.,Tobias,J. H.,Ploubidis,G. } \\
\text { B.,Wells,J. C.,Prabhakaran,D.,Smith,G. D.,Ebrahim,S.,Ben-Shlomo,Y.,Kinra,S. Life-course determinants of bone mass in young } \\
\text { adults from a transitional rural community in India: The Andhra Pradesh Children and Parents Study (APCAPS). American } \\
\text { Journal of Clinical Nutrition.2014;99:1450-1459. }\end{array}$ & $\begin{array}{l}\text { Design, IV, } \\
\text { Age }\end{array}$ \\
\hline 384 & $\begin{array}{l}\text { May, A. L.,Dietz, W. H. The Feeding Infants and Toddlers Study 2008: opportunities to assess parental, cultural, and } \\
\text { environmental influences on dietary behaviors and obesity prevention among young children. J Am Diet Assoc.2010;110:S11-5. }\end{array}$ & Design \\
\hline 385 & $\begin{array}{l}\text { Mazariegos,M.,Hambidge,K. M.,Westcott,J. E.,Solomons,N. W.,Raboy,V.,Das,A.,Goco,N.,Kindem,M.,Wright,L. L.,Krebs,N. F. } \\
\text { Neither a zinc supplement nor phytate-reduced maize nor their combination enhance growth of 6- to 12-month-old Guatemalan } \\
\text { infants. J Nutr.2010;140:1041-8. }\end{array}$ & Country \\
\hline 386 & McGuire, E. Breastfeeding and high maternal body mass index. Breastfeed Rev.2013;21:7-14. & Design \\
\hline 387 & $\begin{array}{l}\text { McNeill, G. Birth weight, feeding practices and weight-for-age of Punjabi children in the UK and in the rural Punjab. Hum Nutr } \\
\text { Clin Nutr.1985;39:69-72. }\end{array}$ & Design \\
\hline 388 & $\begin{array}{l}\text { Mehta KC,Specker BL,Bartholmey S,Giddens J,Ho ML. Trial on timing of introduction to solids and food type on infant growth. } \\
\text { Pediatrics.1998;102:569-73. }\end{array}$ & IV \\
\hline 389 & $\begin{array}{l}\text { Mei, H.,Guo, B.,Yin, B.,Liang, X.,Adair, L.,Thompson, A.,Zhang, J. Interactive Effects of Early Exclusive Breastfeeding and Pre- } \\
\text { Pregnancy Maternal Weight Status on Young Children's BMI - A Chinese Birth Cohort. PLoS One.2015;10:e0144357. }\end{array}$ & IV \\
\hline
\end{tabular}




\begin{tabular}{|c|c|c|}
\hline 390 & $\begin{array}{l}\text { Meldrum,S. J.,D'Vaz,N.,Simmer,K.,Dunstan,J. A.,Hird,K.,Prescott,S. L. Effects of high-dose fish oil supplementation during early } \\
\text { infancy on neurodevelopment and language: a randomised controlled trial. Br J Nutr.2012;108:1443-54. }\end{array}$ & IV \\
\hline 391 & $\begin{array}{l}\text { Melnik, B. Growth and puberty in German children: is there still a positive secular trend? Consumption of milk as a vital factor in } \\
\text { growth development..Bettina Gohlke, Woelfle JF. volume 23/2009. Deutsches Aerzteblatt International.2009;106:656-656. }\end{array}$ & Design \\
\hline 392 & $\begin{array}{l}\text { Mennella, J. A.,Castor, S. M. Sensitive period in flavor learning: effects of duration of exposure to formula flavors on food likes } \\
\text { during infancy. Clin Nutr.2012;31:1022-5. }\end{array}$ & DV \\
\hline 393 & $\begin{array}{l}\text { Merten, S.,Dratva, J.,Ackermann-Liebrich, U. Do baby-friendly hospitals influence breastfeeding duration on a national level?. } \\
\text { Pediatrics.2005;116:e702-8. }\end{array}$ & Design, IV \\
\hline 394 & $\begin{array}{l}\text { Michaelsen, K. F.,Johansen, J. S., Samuelson, G.,Price, P. A.,Christiansen, C. Serum bone gamma-carboxyglutamic acid protein } \\
\text { in a longitudinal study of infants: lower values in formula-fed infants. Pediatr Res.1992;31:401-5. }\end{array}$ & IV \\
\hline 395 & Michaelsen, K. F. Are there negative effects of an excessive protein intake?. Pediatrics.2000;106:1293. & Design \\
\hline 396 & $\begin{array}{l}\text { Michaelsen,K. F.,Milman,N.,Samuelson,G. A longitudinal study of iron status in healthy Danish infants: effects of early iron status, } \\
\text { growth velocity and dietary factors. Acta Paediatr.1995;84:1035-44. }\end{array}$ & IV, DV \\
\hline 397 & Michaelsen,K. F. Cows' milk in complementary feeding. Pediatrics.2000;106:1302-3. & Design \\
\hline 398 & Michaelsen,K. F. Nutrition and growth during infancy. The Copenhagen Cohort Study. Acta Paediatr Suppl.1997;420:1-36. & Design, IV \\
\hline 399 & $\begin{array}{l}\text { Michels, K. B.,Willett, W. C., Graubard, B. I.,Vaidya, R. L.,Cantwell, M. M.,Sansbury, L. B.,Forman, M. R. A longitudinal study of } \\
\text { infant feeding and obesity throughout life course. Int J Obes (Lond).2007;31:1078-85. }\end{array}$ & IV \\
\hline 400 & $\begin{array}{l}\text { Mihrshahi, S.,Battistutta, D.,Magarey, A.,Daniels, L. A. Determinants of rapid weight gain during infancy: baseline results from the } \\
\text { NOURISH randomised controlled trial. BMC Pediatr.2011;11:99. }\end{array}$ & Design \\
\hline 401 & $\begin{array}{l}\text { Millar, L.,Kremer, P.,de Silva-Sanigorski, A.,McCabe, M. P.,Mavoa, H.,Moodie, M.,Utter, J.,Bell, C.,Malakellis, M.,Mathews, } \\
\text { L.,Roberts, G.,Robertson, N.,Swinburn, B. A. Reduction in overweight and obesity from a 3-year community-based intervention in } \\
\text { Australia: the 'It's Your Move!' project. Obes Rev.2011;12 Suppl 2:20-8. }\end{array}$ & IV, Age \\
\hline 402 & $\begin{array}{l}\text { Mimouni-Bloch, A.,Kachevanskaya, A.,Mimouni, F. B.,Shuper, A.,Raveh, E.,Linder, N. Breastfeeding may protect from developing } \\
\text { attention-deficit/hyperactivity disorder. Breastfeed Med.2013;8:363-7. }\end{array}$ & IV \\
\hline 403 & $\begin{array}{l}\text { Mittal, S.,Gupta, M. C. Evaluation of a supplementary feeding programme through take home system. J Trop Pediatr.1980;26:50- } \\
\text { 3. }\end{array}$ & IV \\
\hline 404 & $\begin{array}{l}\text { Miura T,Fukuda M,Mizuno M,Ohte N. Need for public awareness regarding low birth weight and bottle feeding. Hypertens } \\
\text { Res.2016. }\end{array}$ & Design \\
\hline 405 & $\begin{array}{l}\text { Molgaard, C.,Larnkjaer, A.,Mark, A. B.,Michaelsen, K. F. Are early growth and nutrition related to bone health in adolescence? } \\
\text { The Copenhagen Cohort Study of infant nutrition and growth. Am J Clin Nutr.2011;94:1865s-1869s. }\end{array}$ & IV \\
\hline 406 & $\begin{array}{l}\text { Moller, L. M.,de Hoog, M. L.,van Eijsden, M.,Gemke, R. J.,Vrijkotte, T. G. Infant nutrition in relation to eating behaviour and fruit } \\
\text { and vegetable intake at age } 5 \text { years. Br J Nutr.2013;109:564-71. }\end{array}$ & DV \\
\hline
\end{tabular}




\begin{tabular}{|c|c|c|}
\hline 407 & $\begin{array}{l}\text { Monterrosa EC,Frongillo EA,Neufeld LM,Egan KA,Ramakrishnan U,Rasmussen KM. Maternal pre-pregnancy body mass index is } \\
\text { not associated with infant and young child feeding in low-income Mexican children 1-24 months old. Matern Child } \\
\text { Nutr.2015;11:215-28. }\end{array}$ & DV \\
\hline 408 & $\begin{array}{l}\text { Monterrosa,E. C.,Frongillo,E. A.,Vasquez-Garibay,E. M.,Romero-Velarde,E.,Casey,L. M.,Willows,N. D. Predominant breast- } \\
\text { feeding from birth to six months is associated with fewer gastrointestinal infections and increased risk for iron deficiency among } \\
\text { infants. J Nutr.2008;138:1499-504. }\end{array}$ & IV \\
\hline 409 & $\begin{array}{l}\text { Monti G,Viola S,Baro C,Cresi F,Tovo PA,Moro G,Ferrero MP,Conti A,Bertino E. Tolerability of donkey's milk in } 92 \text { highly- } \\
\text { problematic cow's milk allergic children. J Biol Regul Homeost Agents.2012;26:75-82. }\end{array}$ & IV \\
\hline 410 & $\begin{array}{l}\text { Moore,S. E.,Prentice,A. M.,Wagatsuma,Y.,Fulford,A. J.,Collinson,A. C.,Raqib,R.,Vahter,M.,Persson,L. A.,Arifeen,S. E. Early-life } \\
\text { nutritional and environmental determinants of thymic size in infants born in rural Bangladesh. Acta Paediatr.2009;98:1168-75. }\end{array}$ & IV, DV \\
\hline 411 & Moreno M. Early infant feeding and obesity risk. JAMA Pediatr.2014;168:1084. & Design \\
\hline 412 & Morgan JB,Mumford PM. A follow-up study of nutrition and anthropometry in pre-school children. Proc Nutr Soc.1980;39:5a. & Design \\
\hline 413 & $\begin{array}{l}\text { Morgan, J. B.,Lucas, A.,Fewtrell, M. S. Does weaning influence growth and health up to } 18 \text { months?. Archives of Disease in } \\
\text { Childhood: Education and Practice Edition.2004;89:728-733. }\end{array}$ & Design \\
\hline 414 & $\begin{array}{l}\text { Morley,R.,Abbott,R.,Fairweather-Tait,S.,MacFadyen,U.,Stephenson,T.,Lucas,A. Iron fortified follow on formula from } 9 \text { to } 18 \\
\text { months improves iron status but not development or growth: a randomised trial. Arch Dis Child.1999;81:247-52. }\end{array}$ & IV \\
\hline 415 & $\begin{array}{l}\text { Morrow-Tlucak, M.,Haude, R. H.,Ernhart, C. B. Breastfeeding and cognitive development in the first } 2 \text { years of life. Soc Sci } \\
\text { Med.1988;26:635-9. }\end{array}$ & IV \\
\hline 416 & Morton,R. E.,Nysenbaum,A.,Price,K. Iron status in the first year of life. J Pediatr Gastroenterol Nutr.1988;7:707-12. & DV \\
\hline 417 & $\begin{array}{l}\text { Mumford, P.,Morgan, J. B. A longitudinal study of nutrition and growth of infants initially on the upper and lower centile for weight } \\
\text { and age. Int J Obes.1982;6:335-41. }\end{array}$ & IV, DV \\
\hline 418 & $\begin{array}{l}\text { Musaad, S. M.,Donovan, S. M.,Fiese, B. H. Parental perception of child weight in the first two years-of-life: a potential link } \\
\text { between infant feeding and preschoolers' diet. Appetite.2015;91:90-100. }\end{array}$ & $\begin{array}{l}\text { Design, } \\
\text { DV }\end{array}$ \\
\hline 419 & $\begin{array}{l}\text { Nagahara, K.,Dobashi, K., Itabashi, K. Feeding choice has a gender-associated effect on infant growth. Pediatr Int.2013;55:481- } \\
7 .\end{array}$ & IV \\
\hline 420 & $\begin{array}{l}\text { Nakao, R. M. Effects of an education program on the health and illness profile of rural breast-fed babies. Philipp J } \\
\text { Nurs.1988;58:12-8. }\end{array}$ & IV \\
\hline 421 & $\begin{array}{l}\text { Narese, F.,Puccio, G.,Mazzucco, W.,Falzone, A.,Venturella, V.,Narese, D.,Capra, E. Earlier appearance of the ossification center } \\
\text { of the femoral head in breast-fed versus formula-fed infants. Nutrition.2011;27:1108-11. }\end{array}$ & Design, IV \\
\hline 422 & $\begin{array}{l}\text { Nauta,A. J.,Garssen,J. Nutritional programming of immune defense against infections in early life. Nutricia Research, Utrecht, } \\
\text { Netherlands.2014;12:113-126. }\end{array}$ & Design \\
\hline 423 & $\begin{array}{l}\text { Newman,J. E.,Garces,A.,Mazariegos,M.,Michael Hambidge,K.,Manasyan,A.,Tshefu,A.,Lokangaka,A.,Sami,N.,Carlo,W. } \\
\text { A.,Bose,C. L.,Pasha,O.,Goco,N.,Chomba,E.,Goldenberg,R. L.,Wright,L. L.,Koso-Thomas,M.,Krebs,N. F. Theory-driven process }\end{array}$ & Design, \\
\hline
\end{tabular}




\begin{tabular}{|c|c|c|}
\hline & evaluation of a complementary feeding trial in four countries. Health Educ Res.2014;29:297-305. & DV \\
\hline 424 & $\begin{array}{l}\text { Ng, S. C.,Chong, Y. S.,Rauff, M.,Myo, Z. M.,Nurfarah, C.,Deurenberg, P. R. The influence of breast feeding compared to formula } \\
\text { feeding on infant adiposity. Ann Acad Med Singapore.2004;33:S75. }\end{array}$ & Design, IV \\
\hline 425 & $\begin{array}{l}\text { Nguyen, N. D.,Allen, J. R.,Peat, J. K., Schofield, W. N.,Nossar, V.,Eisenbruch, M.,Gaskin, K. J. Growth and feeding practices of } \\
\text { Vietnamese infants in Australia. Eur J Clin Nutr.2004;58:356-62. }\end{array}$ & IV, DV \\
\hline 426 & $\begin{array}{l}\text { Nielsen GA, Thomsen BL,Michaelsen KF. Influence of breastfeeding and complementary food on growth between } 5 \text { and } 10 \\
\text { months. Acta Paediatr.1998;87:911-7. }\end{array}$ & Design \\
\hline 427 & $\begin{array}{l}\text { Niinikoski, H.,Lagstrom, H.,Jokinen, E.,Siltala, M.,Ronnemaa, T.,Viikari, J., Raitakari, O. T.,Jula, A.,Marniemi, J.,Nanto-Salonen, } \\
\text { K.,Simell, O. Impact of repeated dietary counseling between infancy and } 14 \text { years of age on dietary intakes and serum lipids and } \\
\text { lipoproteins: the STRIP study. Circulation.2007;116:1032-40. }\end{array}$ & IV \\
\hline 428 & $\begin{array}{l}\text { Northstone, K.,Emmett, P.,Nethersole, F. The effect of age of introduction to lumpy solids on foods eaten and reported feeding } \\
\text { difficulties at } 6 \text { and } 15 \text { months. J Hum Nutr Diet.2001;14:43-54. }\end{array}$ & DV \\
\hline 429 & $\begin{array}{l}\text { Novotny, R., Coleman, P.,Tenorio, L.,Davison, N.,Camacho, T.,Ramirez, V.,Vijayadeva, V.,Untalan, P.,Tudela, M. D. } \\
\text { Breastfeeding is associated with lower body mass index among children of the Commonwealth of the Northern Mariana Islands. } \\
\text { J Am Diet Assoc.2007;107:1743-6. }\end{array}$ & Design, IV \\
\hline 430 & $\begin{array}{l}\text { Ntouva, A., Rogers, I.,MacAdam, A.,Emmett, P. Weaning practices and iron status of exclusively breast fed infants. Journal of } \\
\text { Human Nutrition \& Dietetics.2011;24:297-298 2p. }\end{array}$ & Design \\
\hline 431 & $\begin{array}{l}\text { Nwaru BI,Takkinen HM,Niemela O,Kaila M,Erkkola M,Ahonen S,Haapala AM,Kenward MG,Pekkanen J,Lahesmaa R,Kere } \\
\text { J,Simell O,Veijola R,Ilonen J,Hyoty H,Knip M,Virtanen SM. Timing of infant feeding in relation to childhood asthma and allergic } \\
\text { diseases. J Allergy Clin Immunol.2013;131:78-86. }\end{array}$ & DV \\
\hline 432 & Obatolu, V. A. Growth pattern of infants fed with a mixture of extruded malted maize and cowpea. Nutrition.2003;19:174-8. & Country \\
\hline 433 & $\begin{array}{l}\text { Oddy, W. H.,Kendall, G. E.,Blair, E.,De Klerk, N. H.,Stanley, F. J.,Landau, L. I.,Silburn, S.,Zubrick, S. Breast feeding and } \\
\text { cognitive development in childhood: a prospective birth cohort study. Paediatr Perinat Epidemiol.2003;17:81-90. }\end{array}$ & IV \\
\hline 434 & $\begin{array}{l}\text { Oddy, W. H.,Robinson, M.,Kendall, G. E.,Li, J.,Zubrick, S. R.,Stanley, F. J. Breastfeeding and early child development: a } \\
\text { prospective cohort study. Acta Paediatr.2011;100:992-9. }\end{array}$ & IV \\
\hline 435 & $\begin{array}{l}\text { Oddy, W. H.,Sherriff, J. L. Breastfeeding, body mass index, asthma and atopy in children. Asia Pac J Public Health.2003;15 } \\
\text { Suppl:S15-7. }\end{array}$ & IV \\
\hline 436 & $\begin{array}{l}\text { O'Donovan,S. M.,O'B Hourihane J,Murray,D. M.,Kenny,L. C.,Khashan,A. S.,Chaoimh,C. N.,Irvine,A. D.,Kiely,M. Neonatal } \\
\text { adiposity increases the risk of atopic dermatitis during the first year of life. J Allergy Clin Immunol.2015. }\end{array}$ & DV \\
\hline 437 & $\begin{array}{l}\text { Oelofse,A.,Van Raaij,J. M.,Benade,A. J.,Dhansay,M. A.,Tolboom,J. J.,Hautvast,J. G. The effect of a micronutrient-fortified } \\
\text { complementary food on micronutrient status, growth and development of 6- to 12-month-old disadvantaged urban South African } \\
\text { infants. Int J Food Sci Nutr.2003;54:399-407. }\end{array}$ & Country \\
\hline 438 & Ong, K. K.,Emmett, P. M.,Noble, S.,Ness, A.,Dunger, D. B. Dietary energy intake at the age of 4 months predicts postnatal weight & IV \\
\hline
\end{tabular}




\begin{tabular}{|c|c|c|}
\hline & gain and childhood body mass index. Pediatrics.2006;117:e503-8. & \\
\hline 439 & $\begin{array}{l}\text { Ong, K. K.,Preece, M. A.,Emmett, P. M.,Ahmed, M. L.,Dunger, D. B. Size at birth and early childhood growth in relation to } \\
\text { maternal smoking, parity and infant breast-feeding: longitudinal birth cohort study and analysis. Pediatr Res.2002;52:863-7. }\end{array}$ & IV \\
\hline 440 & $\begin{array}{l}\text { Onyango, A. W.,Borghi, E.,de Onis, M.,Casanovas Mdel, C.,Garza, C. Complementary feeding and attained linear growth among } \\
\text { 6-23-month-old children. Public Health Nutr.2014;17:1975-83. }\end{array}$ & Design \\
\hline 441 & $\begin{array}{l}\text { Ou, X.,Andres, A.,Cleves, M. A.,Pivik, R. T.,Snow, J. H.,Ding, Z.,Badger, T. M. Sex-specific association between infant diet and } \\
\text { white matter integrity in 8-y-old children. Pediatr Res.2014;76:535-43. }\end{array}$ & IV \\
\hline 442 & $\begin{array}{l}\text { Ounsted, M. K.,Moar, V. A.,Scott, A. Large-for-dates babies at the age of four years: health, handicap and developmental status. } \\
\text { Early Hum Dev.1983;9:9-19. }\end{array}$ & IV \\
\hline 443 & Pachucki MA. Food pattern analysis over time: unhealthful eating trajectories predict obesity. Int J Obes (Lond).2012;36:686-94. & Age \\
\hline 444 & $\begin{array}{l}\text { Parry, J. E.,Ip, D. K.,Chau, P. Y.,Wu, K. M.,Tarrant, M. Predictors and consequences of in-hospital formula supplementation for } \\
\text { healthy breastfeeding newborns. J Hum Lact.2013;29:527-36. }\end{array}$ & IV, DV \\
\hline 445 & Parsons, T. J.,Power, C.,Manor, O. Infant feeding and obesity through the lifecourse. Arch Dis Child.2003;88:793-4. & IV \\
\hline 446 & $\begin{array}{l}\text { Patsourou, A., Konstantinides, T.,Mantadakis, E.,Tsalkidis, A.,Zarras, C.,Balaska, A.,Simopoulos, K.,Chatzimichael, A. Growth of } \\
\text { exclusively breastfed and self-weaned children of Greece aged 0-36 months. Breastfeed Med.2012;7:521-5. }\end{array}$ & IV \\
\hline 447 & $\begin{array}{l}\text { Paul IM,Savage JS,Anzman SL,Beiler JS,Marini ME,Stokes JL,Birch LL. Preventing obesity during infancy: a pilot study. Obesity } \\
\text { (Silver Spring).2011;19:353-61. }\end{array}$ & IV \\
\hline 448 & Paul, A.,Whitehead, R. Infant feeding: the weighting game. Community Outlook.1986:11-7. & Design \\
\hline 449 & Paul, S. P.,Smith, B. A.,Taylor, T. M.,Walker, J. Take with a grain of salt. Clin Chem.2013;59:348-51. & Design \\
\hline 450 & $\begin{array}{l}\text { Peat,J. K.,Mihrshahi,S.,Kemp,A. S.,Marks,G. B.,Tovey,E. R.,Webb,K.,Mellis,C. M.,Leeder,S. R. Three-year outcomes of dietary } \\
\text { fatty acid modification and house dust mite reduction in the Childhood Asthma Prevention Study. J Allergy Clin } \\
\text { Immunol.2004;114:807-13. }\end{array}$ & IV, DV \\
\hline 451 & $\begin{array}{l}\text { Penny,M. E.,Creed-Kanashiro,H. M.,Robert,R. C.,Narro,M. R.,Caulfield,L. E.,Black,R. E. Effectiveness of an educational } \\
\text { intervention delivered through the health services to improve nutrition in young children: a cluster-randomised controlled trial. } \\
\text { Lancet.2005;365:1863-72. }\end{array}$ & IV \\
\hline 452 & $\begin{array}{l}\text { Penrod,J. C.,Anderson,K.,Acosta,P. B. Impact on iron status of introducing cow's milk in the second six months of life. J Pediatr } \\
\text { Gastroenterol Nutr.1990;10:462-7. }\end{array}$ & IV, DV \\
\hline 453 & $\begin{array}{l}\text { Perez-Escamilla, R.,Cohen, R. J.,Brown, K. H.,Rivera, L. L.,Canahuati, J.,Dewey, K. G. Maternal anthropometric status and } \\
\text { lactation performance in a low-income Honduran population: evidence for the role of infants. Am J Clin Nutr.1995;61:528-34. }\end{array}$ & IV, DV \\
\hline 454 & Persson LA. Infant feeding and growth--a longitudinal study in three Swedish communities. Ann Hum Biol.1985;12:41-52. & IV \\
\hline
\end{tabular}




\begin{tabular}{|c|c|c|}
\hline 455 & $\begin{array}{l}\text { Persson,L. A.,Lundstrom,M.,Lonnerdal,B.,Hernell,O. Are weaning foods causing impaired iron and zinc status in 1-year-old } \\
\text { Swedish infants? A cohort study. Acta Paediatr.1998;87:618-22. }\end{array}$ & IV, DV \\
\hline 456 & $\begin{array}{l}\text { Peters,R. L.,Allen,K. J.,Dharmage,S. C.,Lodge,C. J.,Koplin,J. J.,Ponsonby,A. L.,Wake,M.,Lowe,A. J.,Tang,M. L.,Matheson,M. } \\
\text { C.,Gurrin,L. C. Differential factors associated with challenge-proven food allergy phenotypes in a population cohort of infants: a } \\
\text { latent class analysis. Clin Exp Allergy.2015;45:953-63. }\end{array}$ & DV \\
\hline 457 & $\begin{array}{l}\text { Pfluger M,Winkler C,Hummel S,Ziegler AG. Early infant diet in children at high risk for type } 1 \text { diabetes. Horm Metab } \\
\text { Res.2010;42:143-8. }\end{array}$ & IV \\
\hline 458 & $\begin{array}{l}\text { Pham,V. P.,Nguyen,V. H.,Salvignol,B., Treche,S.,Wieringa,F. T.,Dijkhuizen,M. A.,Nguyen,C. K.,Pham,D. T.,Schwartz,H.,Berger,J. } \\
\text { A six-month intervention with two different types of micronutrient-fortified complementary foods had distinct short- and long-term } \\
\text { effects on linear and ponderal growth of Vietnamese infants. J Nutr.2012;142:1735-40. }\end{array}$ & Country \\
\hline 459 & $\begin{array}{l}\text { Phu,P. V.,Hoan,N. V.,Salvignol,B., Treche,S.,Wieringa,F. T.,Khan,N. C., Tuong,P. D.,Berger,J. Complementary foods fortified with } \\
\text { micronutrients prevent iron deficiency and anemia in Vietnamese infants. J Nutr.2010;140:2241-7. }\end{array}$ & DV \\
\hline 460 & $\begin{array}{l}\text { Piemontese, P.,Gianni, M. L.,Braegger, C. P.,Chirico, G.,Gruber, C., Riedler, J.,Arslanoglu, S.,van Stuijvenberg, M.,Boehm, } \\
\text { G.,Jelinek, J.,Roggero, P. Tolerance and safety evaluation in a large cohort of healthy infants fed an innovative prebiotic formula: } \\
\text { a randomized controlled trial. PLoS One.2011;6:e28010. }\end{array}$ & IV \\
\hline 461 & $\begin{array}{l}\text { Pimpin, L.,Jebb, S.,Johnson, L.,Wardle, J.,Ambrosini, G. L. Dietary protein intake is associated with body mass index and weight } \\
\text { up to } 5 \text { y of age in a prospective cohort of twins. Am J Clin Nutr.2016;103:389-97. }\end{array}$ & IV \\
\hline 462 & $\begin{array}{l}\text { Pivik, R. T.,Andres, A.,Badger, T. M. Effects of diet on early stage cortical perception and discrimination of syllables differing in } \\
\text { voice-onset time: a longitudinal ERP study in } 3 \text { and } 6 \text { month old infants. Brain Lang.2012;120:27-41. }\end{array}$ & IV \\
\hline 463 & $\begin{array}{l}\text { Pivik, R. T.,Dykman, R. A.,Jing, H.,Gilchrist, J. M.,Badger, T. M. The influence of infant diet on early developmental changes in } \\
\text { processing human voice speech stimuli: ERP variations in breast and milk formula-fed infants at } 3 \text { and } 6 \text { months after birth. Dev } \\
\text { Neuropsychol.2007;31:279-335. }\end{array}$ & IV \\
\hline 464 & $\begin{array}{l}\text { Piwoz, E. G.,Black, R. E.,Lopez de Romana, G.,Creed de Kanashiro, H.,Brown, K. H. The relationship between infants' preceding } \\
\text { appetite, illness, and growth performance and mothers' subsequent feeding practice decisions. Soc Sci Med.1994;39:851-60. }\end{array}$ & IV, DV \\
\hline 465 & $\begin{array}{l}\text { Piwoz, E. G.,Creed de Kanashiro, H.,Lopez de Romana, G.,Black, R. E.,Brown, K. H. Within- and between-individual variation in } \\
\text { energy intakes by low-income Peruvian infants. Eur J Clin Nutr.1994;48:333-40. }\end{array}$ & IV, DV \\
\hline 466 & $\begin{array}{l}\text { Piwoz,E. G.,Lopez de Romana,G.,Creed de Kanashiro,H.,Black,R. E.,Brown,K. H. Indicators for monitoring the growth of } \\
\text { peruvian infants: weight and length gain vs attained weight and length. Am J Public Health.1994;84:1132-8. }\end{array}$ & IV \\
\hline 467 & $\begin{array}{l}\text { Plagemann, A.,Harder, T.,Kohlhoff, R.,Fahrenkrog, S.,Rodekamp, E.,Franke, K.,Dudenhausen, J. W. Impact of early neonatal } \\
\text { breast-feeding on psychomotor and neuropsychological development in children of diabetic mothers. Diabetes } \\
\text { Care.2005;28:573-8. }\end{array}$ & IV \\
\hline 468 & $\begin{array}{l}\text { Plonka, K. A.,Pukallus, M. L.,Barnett, A.,Holcombe, T. F.,Walsh, L. J.,Seow, W. K. A controlled, longitudinal study of home visits } \\
\text { compared to telephone contacts to prevent early childhood caries. Int J Paediatr Dent.2013;23:23-31. }\end{array}$ & DV \\
\hline 469 & $\begin{array}{l}\text { Poh,Bee Koon,Ng,Boon Koon,Siti Haslinda,Mohd Din,Nik Shanita,Safii,Wong,Jyh Eiin,Budin,Siti Balkis,Ruzita,Abd Talib,Ng,Lai } \\
\text { Oon,Khouw,Ilse,Norimah,A. Karim. Nutritional status and dietary intakes of children aged } 6 \text { months to } 12 \text { years: findings of the }\end{array}$ & Design, IV \\
\hline
\end{tabular}




\begin{tabular}{|c|c|c|}
\hline & Nutrition Survey of Malaysian Children (SEANUTS Malaysia). British Journal of Nutrition.2013;110:S21-35 1p. & \\
\hline 470 & $\begin{array}{l}\text { Polańska, K.,Muszyński, P.,Sobala, W.,Dziewirska, E.,Merecz-Kot, D.,Hanke, W. Maternal lifestyle during pregnancy and child } \\
\text { psychomotor development - Polish Mother and Child Cohort study. Early Human Development.2015;91:317-325. }\end{array}$ & IV \\
\hline 471 & $\begin{array}{l}\text { Pollitt, E.,Gorman, K. S.,Engle, P. L.,Rivera, J. A.,Martorell, R. Nutrition in early life and the fulfillment of intellectual potential. J } \\
\text { Nutr.1995;125:1111s-1118s. }\end{array}$ & Design, IV \\
\hline 472 & $\begin{array}{l}\text { Pollitt, E.,Watkins, W. E.,Husaini, M. A. Three-month nutritional supplementation in Indonesian infants and toddlers benefits } \\
\text { memory function } 8 \text { y later. Am J Clin Nutr.1997;66:1357-63. }\end{array}$ & Country \\
\hline 473 & Potur, A. H.,Kalmaz, N. An investigation into feeding errors of 0-4-month-old infants. J Trop Pediatr.1995;41:120-2. & $\begin{array}{l}\text { Design, } \\
\text { IV,DV }\end{array}$ \\
\hline 474 & Potur, A. H.,Kalmaz, N. An investigation into feeding errors of 0-4-month-old infants. J Trop Pediatr.1996;42:173-5. & $\begin{array}{l}\text { Design, } \\
\text { IV,DV }\end{array}$ \\
\hline 475 & $\begin{array}{l}\text { Prentice P,Koulman A,Matthews L,Acerini CL,Ong KK,Dunger DB. Lipidomic analyses, breast- and formula-feeding, and growth } \\
\text { in infants. J Pediatr.2015;166:276-81.e6. }\end{array}$ & IV \\
\hline 476 & $\begin{array}{l}\text { Pridham, K. F. Infant feeding and anticipatory care: supporting the adaptation of parents to their new babies. Matern Child Nurs } \\
\text { J.1981;10:111-26. }\end{array}$ & Design \\
\hline 477 & $\begin{array}{l}\text { Priego, T.,Sanchez, J.,Pico, C.,Ahrens, W.,Bammann, K.,De Henauw, S.,Fraterman, A.,lacoviello, L.,Lissner, L.,Molnar, } \\
\text { D.,Moreno, L. A.,Siani, A.,Tornaritis, M.,Veidebaum, T.,Palou, A. Influence of breastfeeding on blood-cell transcript-based } \\
\text { biomarkers of health in children. Pediatr Obes.2014;9:463-70. }\end{array}$ & IV \\
\hline 478 & $\begin{array}{l}\text { Prodam, F.,Roccio, M.,Trovato, L.,Ricotti, R.,Moia, S.,Giglione, E.,Petri, A.,Walker, G. E.,Bellone, S.,Bona, G. Adiponectin } \\
\text { oligomers are similarly distributed in adequate-for-gestational-age obese children irrespective of feeding in their first year. Pediatr } \\
\text { Res.2015;77:808-13. }\end{array}$ & IV, DV \\
\hline 479 & $\begin{array}{l}\text { Puri, R.,Chawla, P.,Sharma, M.,Pershad, D. Impact of an on-going supplementary feeding programme on the mental abilities of } \\
\text { children. Indian J Pediatr.1984;51:653-7. }\end{array}$ & IV \\
\hline 480 & $\begin{array}{l}\text { Purwestri, R. C.,Scherbaum, V.,Inayati, D. A.,Wirawan, N. N.,Suryantan, J.,Bloem, M. A.,Pangaribuan, R. V.,Stuetz, } \\
\text { W.,Hoffmann, V.,Qaim, M.,Biesalski, H. K.,Bellows, A. C. Supplementary feeding with locally-produced Ready-to-Use Food } \\
\text { (RUF) for mildly wasted children on Nias Island, Indonesia: comparison of daily and weekly program outcomes. Asia Pac J Clin } \\
\text { Nutr.2012;21:374-9. }\end{array}$ & $\begin{array}{l}\text { Health } \\
\text { status, IV }\end{array}$ \\
\hline 481 & $\begin{array}{l}\text { Qureshi, B.,Morgan, J. B.,Kimer, A. C.,Donaldson, D.,Dickerson, J. W. Feeding practices and birth weights of infants in Southall, } \\
\text { Middlesex. J R Soc Health.1988;108:77-80. }\end{array}$ & IV, DV \\
\hline 482 & $\begin{array}{l}\text { Radhakrishna,K. V.,Hemalatha,R.,Geddam,J. J.,Kumar,P. A.,Balakrishna,N.,Shatrugna,V. Effectiveness of zinc supplementation } \\
\text { to full term normal infants: a community based double blind, randomized, controlled, clinical trial. PLoS One.2013;8:e61486. }\end{array}$ & IV \\
\hline 483 & $\begin{array}{l}\text { Ramokolo, V.,Lombard, C.,Chhagan, M.,Engebretsen, I. M.,Doherty, T.,Goga, A. E.,Fadnes, L. T.,Zembe, W.,Jackson, D. J.,Van } \\
\text { den Broeck, J. Effects of early feeding on growth velocity and overweight/obesity in a cohort of HIV unexposed South African } \\
\text { infants and children. Int Breastfeed J.2015;10:14. }\end{array}$ & IV \\
\hline
\end{tabular}




\begin{tabular}{|c|c|c|}
\hline 484 & $\begin{array}{l}\text { Rao,S., Rajpathak,V. Breastfeeding and weaning practices in relation to nutritional status of infants. Indian Pediatr.1992;29:1533- } \\
\text { 9. }\end{array}$ & IV, DV \\
\hline 485 & Rapley, G. Talking about weaning. Community Pract.2011;84:40-1. & Design \\
\hline 486 & $\begin{array}{l}\text { Rask-Nissila,L.,Jokinen,E.,Terho,P.,Tammi,A.,Hakanen,M.,Ronnemaa,T.,Viikari,J.,Seppanen,R.,Valimaki,I.,Helenius,H.,Simell,O. } \\
\text { Effects of diet on the neurologic development of children at } 5 \text { years of age: the STRIP project. J Pediatr.2002;140:328-33. }\end{array}$ & IV \\
\hline 487 & $\begin{array}{l}\text { Ravelli, A. C.,van der Meulen, J. H.,Osmond, C.,Barker, D. J.,Bleker, O. P. Infant feeding and adult glucose tolerance, lipid } \\
\text { profile, blood pressure, and obesity. Arch Dis Child.2000;82:248-52. }\end{array}$ & IV \\
\hline 488 & $\begin{array}{l}\text { Reifsnider, E. Reversing growth deficiency in children: the effect of a community-based intervention. J Pediatr Health } \\
\text { Care.1998;12:305-12. }\end{array}$ & $\begin{array}{l}\text { Health } \\
\text { status, IV }\end{array}$ \\
\hline 489 & $\begin{array}{l}\text { Requejo,A. M.,Navia,B.,Ortega,R. M.,Lopez-Sobaler,A. M.,Quintas,E.,Gaspar,M. J.,Osorio,O. The age at which meat is first } \\
\text { included in the diet affects the incidence of iron deficiency and ferropenic anaemia in a group of pre-school children from Madrid. } \\
\text { Int J Vitam Nutr Res.1999;69:127-31. }\end{array}$ & Design \\
\hline 490 & $\begin{array}{l}\text { Richards, M.,Wadsworth, M.,Rahimi-Foroushani, A.,Hardy, R.,Kuh, D.,Paul, A. Infant nutrition and cognitive development in the } \\
\text { first offspring of a national UK birth cohort. Dev Med Child Neurol.1998;40:163-7. }\end{array}$ & IV \\
\hline 491 & $\begin{array}{l}\text { Rifas-Shiman SL,Sherry B,Scanlon K,Birch LL,Gillman MW,Taveras EM. Does maternal feeding restriction lead to childhood } \\
\text { obesity in a prospective cohort study?. Arch Dis Child.2011;96:265-9. }\end{array}$ & IV \\
\hline 492 & $\begin{array}{l}\text { Rios-Castillo, I.,Cerezo, S.,Corvalan, C.,Martinez, M.,Kain, J. Risk factors during the prenatal period and the first year of life } \\
\text { associated with overweight in 7-year-old low-income Chilean children. Matern Child Nutr.2015;11:595-605. }\end{array}$ & Design \\
\hline 493 & $\begin{array}{l}\text { Rivera,J. A.,Habicht,J. P. Effect of supplementary feeding on the prevention of mild-to-moderate wasting in conditions of endemic } \\
\text { malnutrition in Guatemala. Bull World Health Organ.2002;80:926-32. }\end{array}$ & IV \\
\hline 494 & Roberts, D. W. Growth of breast fed and bottle fed infants. N Z Med J.1980;92:45-6. & IV \\
\hline 495 & $\begin{array}{l}\text { Robinson, S. M.,Simmonds, S. J.,Jameson, K. A.,Syddall, H. E.,Dennison, E. M.,Cooper, C.,Sayer, A. A. Muscle strength in older } \\
\text { community-dwelling men is related to type of milk feeding in infancy. J Gerontol A Biol Sci Med Sci.2012;67:990-6. }\end{array}$ & IV \\
\hline 496 & $\begin{array}{l}\text { Robinson, S.,Ntani, G.,Simmonds, S.,Syddall, H.,Dennison, E.,Sayer, A. A.,Barker, D.,Cooper, C. Type of milk feeding in infancy } \\
\text { and health behaviours in adult life: findings from the Hertfordshire Cohort Study. Br J Nutr.2013;109:1114-22. }\end{array}$ & IV, DV \\
\hline 497 & Rogan, W. J.,Gladen, B. C. Breast-feeding and cognitive development. Early Hum Dev.1993;31:181-93. & IV \\
\hline 498 & $\begin{array}{l}\text { Rolland-Cachera,M. F.,Maillot,M.,Deheeger,M.,Souberbielle,J. C.,Peneau,S.,Hercberg,S. Association of nutrition in early life with } \\
\text { body fat and serum leptin at adult age. Int J Obes (Lond).2013;37:1116-22. }\end{array}$ & IV \\
\hline 499 & $\begin{array}{l}\text { Rosado,J. L.,Lopez,P.,Garcia,O. P.,Alatorre,J.,Alvarado,C. Effectiveness of the nutritional supplement used in the Mexican } \\
\text { Oportunidades programme on growth, anaemia, morbidity and cognitive development in children aged 12-24 months. Public } \\
\text { Health Nutr.2011;14:931-7. }\end{array}$ & IV \\
\hline 500 & Routi, T.,Ronnemaa, T.,Lapinleimu, H.,Salo, P.,Viikari, J.,Leino, A.,Valimaki, I.,Jokinen, E.,Simell, O. Effect of weaning on serum & IV, DV \\
\hline
\end{tabular}




\begin{tabular}{|c|c|c|}
\hline & lipoprotein(a) concentration: the STRIP baby study. Pediatr Res.1995;38:522-7. & \\
\hline 501 & $\begin{array}{l}\text { Rowland, M. G. The "why" and "when" of introducing food to infants: growth in young breast-fed infants and some nutritional } \\
\text { implications. Am J Clin Nutr.1985;41:459-63. }\end{array}$ & Design \\
\hline 502 & $\begin{array}{l}\text { Roy, S. K.,Fuchs, G. J.,Mahmud, Z.,Ara, G.,Islam, S., Shafique, S.,Akter, S. S.,Chakraborty, B. Intensive nutrition education with } \\
\text { or without supplementary feeding improves the nutritional status of moderately-malnourished children in Bangladesh. J Health } \\
\text { Popul Nutr.2005;23:320-30. }\end{array}$ & $\begin{array}{l}\text { Health } \\
\text { status }\end{array}$ \\
\hline 503 & $\begin{array}{l}\text { Rudnicka, A. R., Owen, C. G.,Richards, M.,Wadsworth, M. E.,Strachan, D. P. Effect of breastfeeding and sociodemographic } \\
\text { factors on visual outcome in childhood and adolescence. Am J Clin Nutr.2008;87:1392-9. }\end{array}$ & IV \\
\hline 504 & Rudy,C. A. Vegetarian diets for children. Pediatr Nurs.1984;10:329-33. & Design \\
\hline 505 & $\begin{array}{l}\text { Ruel, M. T.,Rivera, J.,Habicht, J. P.,Martorell, R. Differential response to early nutrition supplementation: long-term effects on } \\
\text { height at adolescence. Int J Epidemiol.1995;24:404-12. }\end{array}$ & IV, Date \\
\hline 506 & $\begin{array}{l}\text { Russell, C. G.,Taki, S.,Azadi, L.,Campbell, K. J.,Laws, R.,Elliott, R.,Denney-Wilson, E. A qualitative study of the infant feeding } \\
\text { beliefs and behaviours of mothers with low educational attainment. BMC Pediatr.2016;16:69. }\end{array}$ & DV \\
\hline 507 & Ryan, A. S.,Gussler, J. D. Biocultural factors affecting infant feeding and growth. Med Anthropol.1985;9:93-5. & Design \\
\hline 508 & $\begin{array}{l}\text { Rzehak, P.,Sausenthaler, S.,Koletzko, S.,Reinhardt, D.,von Berg, A.,Kramer, U.,Berdel, D.,Bollrath, C., Grubl, A.,Bauer, C. } \\
\text { P.,Wichmann, H. E.,Heinrich, J. Long-term effects of hydrolyzed protein infant formulas on growth--extended follow-up to } 10 \text { y of } \\
\text { age: results from the German Infant Nutritional Intervention (GINI) study. Am J Clin Nutr.2011;94:1803s-1807s. }\end{array}$ & IV \\
\hline 509 & $\begin{array}{l}\text { Saco-Pollitt, C.,Triana, N.,Harahap, H.,Husaini, M.,Jahari, A. B.,Pollitt, E. The eco-cultural context of the undernourished children } \\
\text { in a study on the effects of early supplementary feeding in Indonesia. Eur J Clin Nutr.2000;54 Suppl 2:S11-5. }\end{array}$ & $\begin{array}{l}\text { Design, } \\
\text { Health } \\
\text { status }\end{array}$ \\
\hline 510 & $\begin{array}{l}\text { Sacrey, L. A.,Karl, J. M.,Whishaw, I. Q. Development of rotational movements, hand shaping, and accuracy in advance and } \\
\text { withdrawal for the reach-to-eat movement in human infants aged 6-12 months. Infant Behav Dev.2012;35:543-60. }\end{array}$ & IV, DV \\
\hline 511 & $\begin{array}{l}\text { Saha, K. K.,Frongillo, E. A.,Alam, D. S.,Arifeen, S. E.,Persson, L. A., Rasmussen, K. M. Appropriate infant feeding practices result } \\
\text { in better growth of infants and young children in rural Bangladesh. Am J Clin Nutr.2008;87:1852-9. }\end{array}$ & IV \\
\hline 512 & $\begin{array}{l}\text { Samuel, T. M.,Thomas, T.,Bhat, S.,Kurpad, A. V. Are infants born in baby-friendly hospitals being exclusively breastfed until } 6 \\
\text { months of age?. Eur J Clin Nutr.2012;66:459-65. }\end{array}$ & IV \\
\hline 513 & Saner G,Dagoglu T,Uzkan I,Neyzi O. Promotion of breastfeeding in the postpartum mother. Turk J Pediatr.1985;27:63-8. & IV \\
\hline 514 & Sanger, R. G.,Bystrom, E. B. Breast feeding: does it affect oral facial growth?. Dent Hyg (Chic).1982;56:44-7. & Design \\
\hline 515 & $\begin{array}{l}\text { Santos, I. S.,Matijasevich, A.,Assuncao, M. C.,Valle, N. C.,Horta, B. L.,Goncalves, H. D.,Gigante, D. P.,Martines, J. C.,Pelto, } \\
\text { G.,Victora, C. G. Promotion of Weight Gain in Early Childhood Does Not Increase Metabolic Risk in Adolescents: A 15-Year } \\
\text { Follow-Up of a Cluster-Randomized Controlled Trial. J Nutr.2015;145:2749-55. }\end{array}$ & IV \\
\hline
\end{tabular}




\begin{tabular}{|c|c|c|}
\hline 516 & $\begin{array}{l}\text { Santos,I.,Victora,C. G.,Martines,J.,Goncalves,H.,Gigante,D. P.,Valle,N. J.,Pelto,G. Nutrition counseling increases weight gain } \\
\text { among Brazilian children. J Nutr.2001;131:2866-73. }\end{array}$ & IV \\
\hline 517 & $\begin{array}{l}\text { Satter, Ma,Jabin, Sa,Abedin, N.,Mf, Mf,Parvin, R.,Dhali, M.,Amin, Mz. Development and Evaluation of Weaning Foods Using } \\
\text { Locally Available Nutritious Fruits in Bangladesh. Malaysian Journal of Nutrition.2014;20:83-92. }\end{array}$ & $\begin{array}{l}\text { Design, IV, } \\
\text { DV }\end{array}$ \\
\hline 518 & $\begin{array}{l}\text { Savino, F.,Maccario, S.,Cresi, F.,Grasso, G.,Oggero, R.,Silvestro, L.,Mussa, G. C. Bioimpedance vector analysis in breastfed and } \\
\text { formula-fed infants in the first six months of life. Adv Exp Med Biol.2004;554:501-4. }\end{array}$ & Design, IV \\
\hline 519 & $\begin{array}{l}\text { Savino, F.,Sorrenti, M.,Benetti, S.,Lupica, M. M.,Liguori, S. A.,Oggero, R. Resistin and leptin in breast milk and infants in early } \\
\text { life. Early Hum Dev.2012;88:779-82. }\end{array}$ & Design, IV \\
\hline 520 & Sawley, L. Infant feeding. Nursing (Lond).1989;3:18-23. & Design \\
\hline 521 & $\begin{array}{l}\text { Sazawal,S.,Dhingra,P.,Dhingra,U.,Gupta,S.,Iyengar,V.,Menon,V. P.,Sarkar,A.,Black,R. E. Compliance with home-based } \\
\text { fortification strategies for delivery of iron and zinc: its effect on haematological and growth markers among 6-24 months old } \\
\text { children in north India. J Health Popul Nutr.2014;32:217-26. }\end{array}$ & Country \\
\hline 522 & $\begin{array}{l}\text { Scaglioni, S.,Agostoni, C.,Notaris, R. D.,Radaelli, G.,Radice, N.,Valenti, M.,Giovannini, M.,Riva, E. Early macronutrient intake and } \\
\text { overweight at five years of age. Int J Obes Relat Metab Disord.2000;24:777-81. }\end{array}$ & IV \\
\hline 523 & $\begin{array}{l}\text { Scheiwe, A., Hardy, R.,Watt, R. G. Four-year follow-up of a randomized controlled trial of a social support intervention on infant } \\
\text { feeding practices. Matern Child Nutr.2010;6:328-37. }\end{array}$ & IV \\
\hline 524 & Schmalz, M.,Boos, K.,Schmalz, G.,Huntington, M. K. Failure to thrive. J Fam Pract.2009;58:539-44. & Design \\
\hline 525 & $\begin{array}{l}\text { Schmidt,M. K.,Muslimatun,S.,West,C. E.,Schultink,W.,Gross,R.,Hautvast,J. G. Nutritional status and linear growth of Indonesian } \\
\text { infants in west java are determined more by prenatal environment than by postnatal factors. J Nutr.2002;132:2202-7. }\end{array}$ & Country \\
\hline 526 & $\begin{array}{l}\text { Schroeder, D. G.,Martorell, R.,Rivera, J. A.,Ruel, M. T.,Habicht, J. P. Age differences in the impact of nutritional supplementation } \\
\text { on growth. J Nutr.1995;125:1051s-1059s. }\end{array}$ & IV \\
\hline 527 & $\begin{array}{l}\text { Schroeder, N.,Rushovich, B.,Bartlett, E.,Sharma, S.,Gittelsohn, J.,Caballero, B. Early Obesity Prevention: A Randomized Trial of } \\
\text { a Practice-Based Intervention in 0-24-Month Infants. J Obes.2015;2015:795859. }\end{array}$ & IV \\
\hline 528 & $\begin{array}{l}\text { Schwartz, R.,Vigo, A., de Oliveira, L. D.,Justo Giugliani, E. R. The Effect of a Pro-Breastfeeding and Healthy Complementary } \\
\text { Feeding Intervention Targeting Adolescent Mothers and Grandmothers on Growth and Prevalence of Overweight of Preschool } \\
\text { Children. PLoS One.2015;10:e131884. }\end{array}$ & IV \\
\hline 529 & $\begin{array}{l}\text { Scott, J. A.,Binns, C. W.,Graham, K. I.,Oddy, W. H. Predictors of the early introduction of solid foods in infants: results of a cohort } \\
\text { study. BMC Pediatr.2009;9:60. }\end{array}$ & DV \\
\hline 530 & $\begin{array}{l}\text { Scott, J. A.,Dashti, M.,Al-Sughayer, M.,Edwards, C. A. Timing and Determinants of the Introduction of Complementary Foods in } \\
\text { Kuwait: Results of a Prospective Cohort Study. J Hum Lact.2015;31:467-73. }\end{array}$ & DV \\
\hline 531 & Scully, T. Obesity. Nature.2014;508:S49. & Design \\
\hline 532 & Seal, N.,Broome, M. E. Prepregnancy Body Mass Index and Feeding Practices in Relation to Infants' Growth. J Nurse & Design \\
\hline
\end{tabular}




\begin{tabular}{|c|c|c|}
\hline & Pract.2013;9. & \\
\hline 533 & $\begin{array}{l}\text { Seksaria,S. A., Sheth,M. K. Mass media as a means to bring about behavioral changes in infant and young child feeding practices } \\
\text { amongst tribal mothers of Chikhli taluka, Gujarat. Indian Journal of Public Health Research and Development.2015;6:113-118. }\end{array}$ & Design, IV \\
\hline 534 & $\begin{array}{l}\text { Sellen, D. W.,Thompson, A. L.,Hruschka, D. J.,Stein, A. D.,Martorell, R. Early determinants of non-exclusive breastfeeding } \\
\text { among Guatemalan infants. Adv Exp Med Biol.2004;554:299-301. }\end{array}$ & IV, DV \\
\hline 535 & $\begin{array}{l}\text { Senarath, U.,Godakandage, S. S.,Jayawickrama, H.,Siriwardena, I.,Dibley, M. J. Determinants of inappropriate complementary } \\
\text { feeding practices in young children in Sri Lanka: secondary data analysis of Demographic and Health Survey 2006-2007. Matern } \\
\text { Child Nutr.2012;8 Suppl 1:60-77. }\end{array}$ & Design,DV \\
\hline 536 & $\begin{array}{l}\text { Sethi, V.,Kashyap, S.,Seth, V. Effect of nutrition education of mothers on infant feeding practices. Indian J Pediatr.2003;70:463- } \\
6 .\end{array}$ & IV \\
\hline 537 & $\begin{array}{l}\text { Sezer,R. G.,Aydemir,G.,Akcan,A. B.,Bayoglu,D. S.,Guran,T.,Bozaykut,A. Effect of breastfeeding on serum zinc levels and growth } \\
\text { in healthy infants. Breastfeed Med.2013;8:159-63. }\end{array}$ & Design \\
\hline 538 & $\begin{array}{l}\text { Shaternikov,V. A.,Fateeva,E. M.,Chernikov,M. N. Protein nutrition in early infancy and subsequent periods: its effect on further } \\
\text { development. Bibl Nutr Dieta.1982:95-111. }\end{array}$ & Design \\
\hline 539 & $\begin{array}{l}\text { Shehadeh, N.,Weitzer-Kish, H.,Shamir, R., Shihab, S.,Weiss, R. Impact of early postnatal weight gain and feeding patterns on } \\
\text { body mass index in adolescence. J Pediatr Endocrinol Metab.2008;21:9-15. }\end{array}$ & IV \\
\hline 540 & $\begin{array}{l}\text { Shi,L.,Zhang,J.,Wang,Y.,Caulfield,L. E.,Guyer,B. Effectiveness of an educational intervention on complementary feeding } \\
\text { practices and growth in rural China: a cluster randomised controlled trial. Public Health Nutr.2010;13:556-65. }\end{array}$ & IV \\
\hline 541 & $\begin{array}{l}\text { Shim, J. E.,Kim, J.,Mathai, R. A. Associations of infant feeding practices and picky eating behaviors of preschool children. J Am } \\
\text { Diet Assoc.2011;111:1363-8. }\end{array}$ & DV \\
\hline 542 & $\begin{array}{l}\text { Simell, O.,Niinikoski, H.,Viikari, J.,Rask-Nissila, L.,Tammi, A., Ronnemaa, T. Cardiovascular disease risk factors in young children } \\
\text { in the STRIP baby project. Special Turku coronary Risk factor Intervention Project for children. Ann Med.1999;31 Suppl 1:55-61. }\end{array}$ & IV \\
\hline 543 & $\begin{array}{l}\text { Simondon, K. B.,Gartner, A.,Berger, J.,Cornu, A.,Massamba, J. P.,San Miguel, J. L.,Ly, C.,Missotte, I., Simondon, F., Traissac, } \\
\text { P.,Delpeuch, F.,Maire, B. Effect of early, short-term supplementation on weight and linear growth of 4-7-mo-old infants in } \\
\text { developing countries: a four-country randomized trial. Am J Clin Nutr.1996;64:537-45. }\end{array}$ & IV,Country \\
\hline 544 & $\begin{array}{l}\text { Singhal A,Cole TJ,Fewtrell M,Kennedy K,Stephenson T,Elias-Jones A,Lucas A. Promotion of faster weight gain in infants born } \\
\text { small for gestational age: is there an adverse effect on later blood pressure?. Circulation.2007;115:213-20. }\end{array}$ & $\begin{array}{l}\text { Health } \\
\text { status, IV }\end{array}$ \\
\hline 545 & Singhal, A.,Lucas, A. Early origins of cardiovascular disease: is there a unifying hypothesis?. Lancet.2004;363:1642-5. & Design \\
\hline 546 & $\begin{array}{l}\text { Skau,J. K.,Touch,B.,Chhoun,C.,Chea,M.,Unni,U. S.,Makurat,J.,Filteau,S.,Wieringa,F. T.,Dijkhuizen,M. A.,Ritz,C.,Wells,J. } \\
\text { C.,Berger,J.,Friis,H.,Michaelsen,K. F.,Roos,N. Effects of animal source food and micronutrient fortification in complementary food } \\
\text { products on body composition, iron status, and linear growth: a randomized trial in Cambodia. Am J Clin Nutr.2015;101:742-51. }\end{array}$ & IV \\
\hline 547 & $\begin{array}{l}\text { Skledar, M. T.,Milosevic, M. Breastfeeding and time of complementary food introduction as predictors of obesity in children. Cent } \\
\text { Eur J Public Health.2015;23:26-31. }\end{array}$ & Design \\
\hline
\end{tabular}




\begin{tabular}{|c|c|c|}
\hline 548 & $\begin{array}{l}\text { Sloan, S.,Gildea, A.,Stewart, M.,Sneddon, H.,Iwaniec, D. Early weaning is related to weight and rate of weight gain in infancy. } \\
\text { Child Care Health Dev.2008;34:59-64. }\end{array}$ & Design \\
\hline 549 & $\begin{array}{l}\text { Snijders, B. E.,Thijs, C.,van Ree, R.,van den Brandt, P. A. Age at first introduction of cow milk products and other food products } \\
\text { in relation to infant atopic manifestations in the first } 2 \text { years of life: the KOALA Birth Cohort Study. Pediatrics.2008;122:e115-22. }\end{array}$ & DV \\
\hline 550 & $\begin{array}{l}\text { Soto-Ramirez, N.,Karmaus, W.,Zhang, H.,Davis, S.,Agarwal, S.,Albergottie, A. Modes of infant feeding and the occurrence of } \\
\text { coughing/wheezing in the first year of life. J Hum Lact.2013;29:71-80. }\end{array}$ & IV, DV \\
\hline 551 & Sparks, J. W. Fetal growth and diet. Mead Johnson Symp Perinat Dev Med.1984:21-7. & Design \\
\hline 552 & $\begin{array}{l}\text { Specker BL,Beck A,Kalkwarf H,Ho M. Randomized trial of varying mineral intake on total body bone mineral accretion during the } \\
\text { first year of life. Pediatrics.1997;99:E12. }\end{array}$ & IV \\
\hline 553 & $\begin{array}{l}\text { Spence,A. C.,Campbell,K. J.,Crawford,D. A.,McNaughton,S. A.,Hesketh,K. D. Mediators of improved child diet quality following a } \\
\text { health promotion intervention: the Melbourne InFANT Program. Int J Behav Nutr Phys Act.2014;11:137. }\end{array}$ & IV, DV \\
\hline 554 & $\begin{array}{l}\text { Sreedhara, M. S.,Banapurmath, C. R. A study of nutritional status of infants in relation to their complementary feeding practices. } \\
\text { Current Pediatric Research.2014;18:39-41. }\end{array}$ & Design \\
\hline 555 & Stahl, M. D.,Guida, D. A. Slow weight gain in the breast-fed infant: management options. Pediatr Nurs.1984;10:117-20, 164. & Design \\
\hline 556 & Stang,J. Improving the eating patterns of infants and toddlers. J Am Diet Assoc.2006;106:S7-9. & Design \\
\hline 557 & $\begin{array}{l}\text { Stifter, C. A.,Anzman-Frasca, S.,Birch, L. L.,Voegtline, K. Parent use of food to soothe infant/toddler distress and child weight } \\
\text { status. An exploratory study. Appetite.2011;57:693-9. }\end{array}$ & Design, IV \\
\hline 558 & $\begin{array}{l}\text { Strbak, V.,Skultetyova, M.,Hromadova, M.,Randuskova, A.,Macho, L. Late effects of breast-feeding and early weaning: seven- } \\
\text { year prospective study in children. Endocr Regul.1991;25:53-7. }\end{array}$ & IV \\
\hline 559 & $\begin{array}{l}\text { Stuff, J. E.,Garza, C.,Boutte, C.,Fraley, J. K.,Smith, E. O.,Klein, E. R.,Nichols, B. L. Sources of variance in milk and caloric } \\
\text { intakes in breast-fed infants: implications for lactation study design and interpretation. Am J Clin Nutr.1986;43:361-6. }\end{array}$ & Design, IV \\
\hline 560 & Stuff, J. E.,Nichols, B. L. Nutrient intake and growth performance of older infants fed human milk. J Pediatr.1989;115:959-68. & DV \\
\hline 561 & $\begin{array}{l}\text { Stunkard, A. J.,Berkowitz, R. I.,Schoeller, D.,Maislin, G.,Stallings, V. A. Predictors of body size in the first } 2 \text { y of life: a high-risk } \\
\text { study of human obesity. Int J Obes Relat Metab Disord.2004;28:503-13. }\end{array}$ & IV \\
\hline 562 & $\begin{array}{l}\text { Stunkard, A. J.,Berkowitz, R. I.,Stallings, V. A.,Schoeller, D. A. Energy intake, not energy output, is a determinant of body size in } \\
\text { infants. Am J Clin Nutr.1999;69:524-30. }\end{array}$ & IV \\
\hline 563 & $\begin{array}{l}\text { Super, C. M.,Herrera, M. G.,Mora, J. O. Long-term effects of food supplementation and psychosocial intervention on the physical } \\
\text { growth of Colombian infants at risk of malnutrition. Child Dev.1990;61:29-49. }\end{array}$ & IV \\
\hline 564 & $\begin{array}{l}\text { Svahn,J. C.,Feldl,F.,Raiha,N. C.,Koletzko,B.,Axelsson,I. E. Different quantities and quality of fat in milk products given to young } \\
\text { children: effects on long chain polyunsaturated fatty acids and trans fatty acids in plasma. Acta Paediatr.2002;91:20-9. }\end{array}$ & DV \\
\hline 565 & $\begin{array}{l}\text { Taitz, L. S.,Lukmanji, Z. Alterations in feeding patterns and rates of weight gain in South Yorkshire infants, 1971-1977. Hum } \\
\text { Biol.1981;53:313-20. }\end{array}$ & IV, Date \\
\hline
\end{tabular}




\begin{tabular}{|c|c|c|}
\hline 566 & Taitz, L. Feeding children in the first year of life. Midwife Health Visitor \& Community Nurse.1990;26:81-84. & Design \\
\hline 567 & Tann, S. P.,Wheeler, E. F. Food intakes and growth of young Chinese children in London. Community Med.1980;2:20-4. & IV, DV \\
\hline 568 & $\begin{array}{l}\text { Tantracheewathorn,S.,Lohajaroensub,S. Incidence and risk factors of iron deficiency anemia in term infants. J Med Assoc } \\
\text { Thai.2005;88:45-51. }\end{array}$ & IV, DV \\
\hline 569 & $\begin{array}{l}\text { Tanzer F,Gumuser C. A study of the growth of } 200 \text { newborn babies for a period of } 6 \text { months according to the type of nutrition. } \\
\text { Ann Trop Paediatr.1989;9:54-8. }\end{array}$ & IV \\
\hline 570 & $\begin{array}{l}\text { Tarrant, M.,Fong, D. Y.,Wu, K. M.,Lee, I. L.,Wong, E. M.,Sham, A.,Lam, C., Dodgson, J. E. Breastfeeding and weaning practices } \\
\text { among Hong Kong mothers: a prospective study. BMC Pregnancy Childbirth.2010;10:27. }\end{array}$ & DV \\
\hline 571 & $\begin{array}{l}\text { Taveras EM,Blackburn K,Gillman MW,Haines J,McDonald J,Price S,Oken E. First steps for mommy and me: a pilot intervention } \\
\text { to improve nutrition and physical activity behaviors of postpartum mothers and their infants. Matern Child Health J.2011;15:1217- } \\
27 \text {. }\end{array}$ & IV \\
\hline 572 & $\begin{array}{l}\text { Tawia, S. Breastfeeding, brain structure and function, cognitive development and educational attainment. Breastfeed } \\
\text { Rev.2013;21:15-20. }\end{array}$ & Design \\
\hline 573 & Tawia, S. Childhood obesity and being breastfed. Breastfeed Rev.2013;21:42-8. & Design \\
\hline 574 & $\begin{array}{l}\text { Taylor,A.,Redworth,E. W.,Morgan,J. B. Influence of diet on iron, copper, and zinc status in children under } 24 \text { months of age. Biol } \\
\text { Trace Elem Res.2004;97:197-214. }\end{array}$ & DV \\
\hline 575 & $\begin{array}{l}\text { Thakur, R.,Singh, M. G.,Chaudhary, S.,Manuja, N. Effect of mode of delivery and feeding practices on acquisition of oral } \\
\text { Streptococcus mutans in infants. Int J Paediatr Dent.2012;22:197-202. }\end{array}$ & DV \\
\hline 576 & $\begin{array}{l}\text { Theron, M.,Amissah, A.,Kleynhans, I. C.,Albertse, E.,Maclntyre, U. E. Inadequate dietary intake is not the cause of stunting } \\
\text { amongst young children living in an informal settlement in Gauteng and rural Limpopo Province in South Africa: the NutriGro } \\
\text { study. Public Health Nutr.2007;10:379-89. }\end{array}$ & Design \\
\hline 577 & $\begin{array}{l}\text { Thomson, J. L.,Tussing-Humphreys, L. M.,Goodman, M. H. Delta Healthy Sprouts: a randomized comparative effectiveness trial } \\
\text { to promote maternal weight control and reduce childhood obesity in the Mississippi Delta. Contemp Clin Trials.2014;38:82-91. }\end{array}$ & Design, IV \\
\hline 578 & $\begin{array}{l}\text { Thorisdottir, B., Gunnarsdottir, I.,Thorisdottir, A. V.,Palsson, G. I.,Halldorsson, T. I.,Thorsdottir, I. Nutrient intake in infancy and } \\
\text { body mass index at six years in two population-based cohorts recruited before and after revision of infant dietary } \\
\text { recommendations. Ann Nutr Metab.2013;63:145-51. }\end{array}$ & IV \\
\hline 579 & $\begin{array}{l}\text { Thorsdottir, I.,Gunnarsdottir, I.,Palsson, G. I. Birth weight, growth and feeding in infancy: relation to serum lipid concentration in } \\
\text { 12-month-old infants. Eur J Clin Nutr.2003;57:1479-85. }\end{array}$ & IV, DV \\
\hline 580 & $\begin{array}{l}\text { Timby, N.,Domellof, E.,Hernell, O.,Lonnerdal, B.,Domellof, M. Neurodevelopment, nutrition, and growth until } 12 \text { mo of age in } \\
\text { infants fed a low-energy, low-protein formula supplemented with bovine milk fat globule membranes: a randomized controlled } \\
\text { trial. Am J Clin Nutr.2014;99:860-8. }\end{array}$ & IV \\
\hline 581 & $\begin{array}{l}\text { Townsend, E.,Pitchford, N. J. Baby knows best? The impact of weaning style on food preferences and body mass index in early } \\
\text { childhood in a case-controlled sample. BMJ Open.2012;2:e000298. }\end{array}$ & IV \\
\hline
\end{tabular}




\begin{tabular}{|c|c|c|}
\hline 582 & $\begin{array}{l}\text { Tripathy, R.,Das, R. N.,Das, M. M.,Parija, A. C. Growth in the first year in children following IAP Policy on Infant Feeding. Indian } \\
\text { Pediatr.2000;37:1051-9. }\end{array}$ & IV \\
\hline 583 & $\begin{array}{l}\text { Tulldahl, J.,Pettersson, K.,Andersson, S. W.,Hulthen, L. Mode of infant feeding and achieved growth in adolescence: early } \\
\text { feeding patterns in relation to growth and body composition in adolescence. Obes Res.1999;7:431-7. }\end{array}$ & Design \\
\hline 584 & $\begin{array}{l}\text { Umer, A.,Hamilton, C.,Britton, C. M.,Mullett, M. D.,John, C.,Neal, W.,Lilly, C. L. Association between Breastfeeding and } \\
\text { Childhood Obesity: Analysis of a Linked Longitudinal Study of Rural Appalachian Fifth-Grade Children. Child Obes.2015;11:449- } \\
55 .\end{array}$ & IV \\
\hline 585 & $\begin{array}{l}\text { Unni, J. C.,Richard, J. Growth and morbidity of breast-fed and artificially-fed infants in urban south Indian families. J Trop } \\
\text { Pediatr.1988;34:179-81. }\end{array}$ & IV \\
\hline 586 & $\begin{array}{l}\text { Vail, B.,Prentice, P.,Dunger, D. B.,Hughes, I. A.,Acerini, C. L.,Ong, K. K. Age at Weaning and Infant Growth: Primary Analysis } \\
\text { and Systematic Review. Journal of Pediatrics.2015;167:317-324.e1. }\end{array}$ & Design \\
\hline 587 & Valman, H. B. The first year of life: feeding and feeding problems. Br Med J.1980;280:457-60. & Design \\
\hline 588 & $\begin{array}{l}\text { van der Willik, E. M.,Vrijkotte, T. G.,Altenburg, T. M.,Gademan, M. G.,Kist-van Holthe, J. Exclusively breastfed overweight infants } \\
\text { are at the same risk of childhood overweight as formula fed overweight infants. Arch Dis Child.2015;100:932-7. }\end{array}$ & IV \\
\hline 589 & $\begin{array}{l}\text { van Dijk, C. E.,Innis, S. M. Growth-curve standards and the assessment of early excess weight gain in infancy. } \\
\text { Pediatrics.2009;123:102-8. }\end{array}$ & IV, DV \\
\hline 590 & $\begin{array}{l}\text { van Eijsden, M.,Meijers, C. M.,Jansen, J. E.,de Kroon, M. L.,Vrijkotte, T. G. Cultural variation in early feeding pattern and } \\
\text { maternal perceptions of infant growth. Br J Nutr.2015;114:481-8. }\end{array}$ & DV \\
\hline 591 & $\begin{array}{l}\text { van Rheenen,P. F.,de Moor,L. T.,Eschbach,S.,Brabin,B. J. A cohort study of haemoglobin and zinc protoporphyrin levels in term } \\
\text { Zambian infants: effects of iron stores at birth, complementary food and placental malaria. Eur J Clin Nutr.2008;62:1379-87. }\end{array}$ & Country \\
\hline 592 & $\begin{array}{l}\text { van t Hof Msc, M. A. The influence of breastfeeding and complementary foods on growth until three years of age in the Euro- } \\
\text { Growth Study. Pediatrics.2000;106:1281a-1281. }\end{array}$ & Design \\
\hline 593 & $\begin{array}{l}\text { Vazir,S.,Engle,P.,Balakrishna,N.,Griffiths,P. L.,Johnson,S. L.,Creed-Kanashiro,H.,Fernandez Rao,S.,Shroff,M. R.,Bentley,M. E. } \\
\text { Cluster-randomized trial on complementary and responsive feeding education to caregivers found improved dietary intake, growth } \\
\text { and development among rural Indian toddlers. Matern Child Nutr.2013;9:99-117. }\end{array}$ & IV \\
\hline 594 & $\begin{array}{l}\text { Veena SR,Krishnaveni GV,Srinivasan K,Wills AK,Hill JC,Kurpad AV,Muthayya S,Karat SC,Nalinakshi M,Fall CH. Infant feeding } \\
\text { practice and childhood cognitive performance in South India. Arch Dis Child.2010;95:347-54. }\end{array}$ & Country \\
\hline 595 & $\begin{array}{l}\text { Veena, S. R.,Krishnaveni, G. V.,Wills, A. K.,Hill, J. C.,Karat, S. C.,Fall, C. H. Glucose tolerance and insulin resistance in Indian } \\
\text { children: relationship to infant feeding pattern. Diabetologia.2011;54:2533-7. }\end{array}$ & Country \\
\hline 596 & $\begin{array}{l}\text { Vehapoglu, A.,Yazici, M.,Demir, A. D.,Turkmen, S.,Nursoy, M.,Ozkaya, E. Early infant feeding practice and childhood obesity: the } \\
\text { relation of breast-feeding and timing of solid food introduction with childhood obesity. J Pediatr Endocrinol Metab.2014;27:1181- } \\
7 \text {. }\end{array}$ & Design \\
\hline 597 & $\begin{array}{l}\text { Venancio, S. I.,Saldiva, S. R.,Mondini, L.,Levy, R. B.,Escuder, M. M. Early interruption of exclusive breastfeeding and associated } \\
\text { factors, state of Sao Paulo, Brazil. J Hum Lact.2008;24:168-74. }\end{array}$ & $\begin{array}{l}\text { Design, } \\
\text { DV }\end{array}$ \\
\hline
\end{tabular}




\begin{tabular}{|c|c|c|}
\hline 598 & $\begin{array}{l}\text { Verd S,Barriuso L,Gich I,Gutierrez A,Nadal-Amat J,Carreras E. Risk of early breastfeeding cessation among symmetrical, small } \\
\text { for gestational age infants. Ann Hum Biol.2013;40:146-51. }\end{array}$ & $\begin{array}{l}\text { Health } \\
\text { status, DV }\end{array}$ \\
\hline 599 & $\begin{array}{l}\text { Victora, C. G.,Matijasevich, A.,Santos, I. S.,Barros, A. J.,Horta, B. L.,Barros, F. C. Breastfeeding and feeding patterns in three } \\
\text { birth cohorts in Southern Brazil: trends and differentials. Cad Saude Publica.2008;24 Suppl 3:S409-16. }\end{array}$ & IV, DV \\
\hline 600 & $\begin{array}{l}\text { Victora,C. G.,Vaughan,J. P.,Martines,J. C.,Barcelos,L. B. Is prolonged breast-feeding associated with malnutrition?. Am J Clin } \\
\text { Nutr.1984;39:307-14. }\end{array}$ & IV \\
\hline 601 & Villalpando, S. Feeding mode, infections, and anthropometric status in early childhood. Pediatrics.2000;106:1282-3. & Design \\
\hline 602 & $\begin{array}{l}\text { Virtanen, S. M.,Laara, E.,Hypponen, E.,Reijonen, H.,Rasanen, L.,Aro, A.,Knip, M.,llonen, J.,Akerblom, H. K. Cow's milk } \\
\text { consumption, HLA-DQB1 genotype, and type } 1 \text { diabetes: a nested case-control study of siblings of children with diabetes. } \\
\text { Childhood diabetes in Finland study group. Diabetes.2000;49:912-7. }\end{array}$ & DV \\
\hline 603 & $\begin{array}{l}\text { Virtanen, S. M.,Rasanen, L., Ylonen, K.,Aro, A.,Clayton, D.,Langholz, B.,Pitkaniemi, J.,Savilahti, E.,Lounamaa, R., Tuomilehto, } \\
\text { J.,et al.,. Early introduction of dairy products associated with increased risk of IDDM in Finnish children. The Childhood in } \\
\text { Diabetes in Finland Study Group. Diabetes.1993;42:1786-90. }\end{array}$ & DV \\
\hline 604 & $\begin{array}{l}\text { Vobecky,J. S.,Vobecky,J.,Shapcott,D.,Demers,P. P. Nutrient intake patterns and nutritional status with regard to relative weight in } \\
\text { early infancy. Am J Clin Nutr.1983;38:730-8. }\end{array}$ & IV \\
\hline 605 & $\begin{array}{l}\text { Wandel, M.,Fagerli, R. Aa,Olsen, P. T.,Borch-Iohnsen, B.,Ek, J. Iron status and weaning practices among Norwegian and } \\
\text { immigrant infants. Nutrition Research.1996;16:251-265. }\end{array}$ & Design \\
\hline 606 & $\begin{array}{l}\text { Wang RJ,Trehan I,LaGrone LN,Weisz AJ,Thakwalakwa CM,Maleta KM,Manary MJ. Investigation of food acceptability and } \\
\text { feeding practices for lipid nutrient supplements and blended flours used to treat moderate malnutrition. J Nutr Educ } \\
\text { Behav.2013;45:258-63. }\end{array}$ & $\begin{array}{l}\text { Health } \\
\text { status, } \\
\text { Country }\end{array}$ \\
\hline 607 & $\begin{array}{l}\text { Watt, R. G.,Tull, K. I.,Hardy, R.,Wiggins, M.,Kelly, Y.,Molloy, B.,Dowler, E.,Apps, J.,McGlone, P. Effectiveness of a social support } \\
\text { intervention on infant feeding practices: randomised controlled trial. J Epidemiol Community Health.2009;63:156-62. }\end{array}$ & IV, DV \\
\hline 608 & $\begin{array}{l}\text { Weber, M.,Grote, V.,Closa-Monasterolo, R.,Escribano, J.,Langhendries, J. P.,Dain, E.,Giovannini, M.,Verduci, E.,Gruszfeld, } \\
\text { D.,Socha, P.,Koletzko, B. Lower protein content in infant formula reduces BMI and obesity risk at school age: follow-up of a } \\
\text { randomized trial. Am J Clin Nutr.2014;99:1041-51. }\end{array}$ & IV \\
\hline 609 & $\begin{array}{l}\text { Weijs, P. J.,Kool, L. M.,van Baar, N. M.,van der Zee, S. C. High beverage sugar as well as high animal protein intake at infancy } \\
\text { may increase overweight risk at } 8 \text { years: a prospective longitudinal pilot study. Nutr J.2011;10:95. }\end{array}$ & IV \\
\hline 610 & $\begin{array}{l}\text { Wen, L. M.,Baur, L. A.,Simpson, J. M.,Xu, H.,Hayes, A. J.,Hardy, L. L.,Williams, M.,Rissel, C. Sustainability of Effects of an Early } \\
\text { Childhood Obesity Prevention Trial Over Time: A Further 3-Year Follow-up of the Healthy Beginnings Trial. JAMA } \\
\text { Pediatr.2015;169:543-51. }\end{array}$ & IV \\
\hline 611 & $\begin{array}{l}\text { West, C. E.,Hernell, O.,Andersson, Y.,Sjostedt, M.,Hammarstrom, M. L. Probiotic effects on T-cell maturation in infants during } \\
\text { weaning. Clin Exp Allergy.2012;42:540-9. }\end{array}$ & IV, DV \\
\hline 612 & Westphal, R.,Phillips, G.,Irwig, L. M. Infant care and feeding in an urban black population. S Afr Med J.1981;60:778-81. & DV, Date \\
\hline
\end{tabular}




\begin{tabular}{|c|c|c|}
\hline 613 & $\begin{array}{l}\text { Weyermann, M.,Rothenbacher, D.,Brenner, H. Duration of breastfeeding and risk of overweight in childhood: a prospective birth } \\
\text { cohort study from Germany. Int J Obes (Lond).2006;30:1281-7. }\end{array}$ & IV \\
\hline 614 & $\begin{array}{l}\text { Wharf,S. G.,Fox,T. E.,Fairweather-Tait,S. J.,Cook,J. D. Factors affecting iron stores in infants 4-18 months of age. Eur J Clin } \\
\text { Nutr.1997;51:504-9. }\end{array}$ & Design \\
\hline 615 & $\begin{array}{l}\text { Whitehead, R. G.,Paul, A. A.,Ahmed, E. A. Weaning practices in the United Kingdom and variations in anthropometric } \\
\text { development. Acta Paediatr Scand Suppl.1986;323:14-23. }\end{array}$ & Design, IV \\
\hline 616 & Whitehead, R. G.,Paul, A. A. Infant growth and human milk requirements. A fresh approach. Lancet.1981;2:161-3. & IV \\
\hline 617 & $\begin{array}{l}\text { Whitten, C. F.,Stewart, R. A. The effect of dietary sodium in infancy on blood pressure and related factors. Studies of infants fed } \\
\text { salted and unsalted diets for five months at eight months and eight years of age. Acta Paediatr Scand Suppl.1980;279:1-17. }\end{array}$ & IV \\
\hline 618 & $\begin{array}{l}\text { Wiberger, M.,Eiben, G.,Lissner, L.,Mehlig, K.,Papoutsou, S.,Hunsberger, M. Children consuming milk cereal drink are at } \\
\text { increased risk for overweight: The IDEFICS Sweden study, on behalf of the IDEFICS Consortium. Scand J Public } \\
\text { Health.2014;42:518-24. }\end{array}$ & Design \\
\hline 619 & $\begin{array}{l}\text { Wigg, N. R.,Tong, S.,McMichael, A. J.,Baghurst, P. A.,Vimpani, G.,Roberts, R. Does breastfeeding at six months predict cognitive } \\
\text { development?. Aust N Z J Public Health.1998;22:232-6. }\end{array}$ & IV \\
\hline 620 & $\begin{array}{l}\text { Wijga,A.,Vyas,U.,Vyas,A.,Sharma,V.,Pandya,N.,Nabarro,D. Feeding, illness and nutritional status of young children in rural } \\
\text { Gujarat. Hum Nutr Clin Nutr.1983;37:255-69. }\end{array}$ & Design, IV \\
\hline 621 & $\begin{array}{l}\text { Williams, D. M.,Martin, R. M.,Davey Smith, G.,Alberti, K. G.,Ben-Shlomo, Y.,McCarthy, A. Associations of infant nutrition with } \\
\text { insulin resistance measures in early adulthood: evidence from the Barry-Caerphilly Growth (BCG) study. PLoS } \\
\text { One.2012;7:e34161. }\end{array}$ & IV, DV \\
\hline 622 & $\begin{array}{l}\text { Williams, J.,Wolff, A.,Daly, A.,MacDonald, A.,Aukett, A.,Booth, I. W. Iron supplemented formula milk related to reduction in } \\
\text { psychomotor decline in infants from inner city areas: randomised study. Bmj.1999;318:693-7. }\end{array}$ & IV \\
\hline 623 & Winick, M. The role of early nutrition in subsequent development and optimal future health. Bull N Y Acad Med.1989;65:1020-5. & Design \\
\hline 624 & Winkelstein,M. L. Overfeeding in infancy: the early introduction of solid foods. Pediatr Nurs.1984;10:205-8, 236. & Design \\
\hline 625 & $\begin{array}{l}\text { Wölfle, J. Growth and puberty in German children: is there still a positive secular trend? In reply..Consumption of milk as a vital } \\
\text { factor in growth development. Melnik B, Dtsch Arzetebl 2009, volume 206. Deutsches Aerzteblatt International.2009;106:656- } \\
656 .\end{array}$ & Design \\
\hline 626 & $\begin{array}{l}\text { Wright, C. M.,Parkinson, K. N.,Drewett, R. F. Why are babies weaned early? Data from a prospective population based cohort } \\
\text { study. Arch Dis Child.2004;89:813-6. }\end{array}$ & DV \\
\hline 627 & $\begin{array}{l}\text { Wright, C. M.,Parkinson, K.,Scott, J. Breast-feeding in a UK urban context: who breast-feeds, for how long and does it matter?. } \\
\text { Public Health Nutr.2006;9:686-91. }\end{array}$ & IV \\
\hline 628 & $\begin{array}{l}\text { Wright, M. J.,Bentley, M. E.,Mendez, M. A.,Adair, L. S. The interactive association of dietary diversity scores and breast-feeding } \\
\text { status with weight and length in Filipino infants aged 6-24 months. Public Health Nutr.2015;18:1762-73. }\end{array}$ & Country \\
\hline
\end{tabular}




\begin{tabular}{|c|c|c|}
\hline 629 & $\begin{array}{l}\text { Yew, K. S.,Webber, B.,Hodges, J.,Carter, N. J. Clinical inquiries: are there any known health risks to early introduction of solids to } \\
\text { an infant's diet?. J Fam Pract.2009;58:219-20. }\end{array}$ & Design \\
\hline 630 & $\begin{array}{l}\text { Young RJ,Antonson DL,Ferguson PW,Murray ND,Merkel K,Moore TE. Neonatal and infant feeding: effect on bone density at } 4 \\
\text { years. J Pediatr Gastroenterol Nutr.2005;41:88-93. }\end{array}$ & Design \\
\hline 631 & $\begin{array}{l}\text { Yousafzai, A. K.,Rasheed, M. A.,Rizvi, A.,Armstrong, R.,Bhutta, Z. A. Effect of integrated responsive stimulation and nutrition } \\
\text { interventions in the Lady Health Worker programme in Pakistan on child development, growth, and health outcomes: a cluster- } \\
\text { randomised factorial effectiveness trial. Lancet.2014;384:1282-93. }\end{array}$ & Country \\
\hline 632 & $\begin{array}{l}\text { Ystrom, E. Breastfeeding cessation and symptoms of anxiety and depression: a longitudinal cohort study. BMC Pregnancy } \\
\text { Childbirth.2012;12:36. }\end{array}$ & IV, DV \\
\hline 633 & $\begin{array}{l}\text { Zadik Z,Borondukov E,Zung A,Reifen R. Adult height and weight of breast-fed and bottle-fed Israeli infants. J Pediatr } \\
\text { Gastroenterol Nutr.2003;37:462-7. }\end{array}$ & IV \\
\hline 634 & $\begin{array}{l}\text { Zaman, S.,Jalil, F., Saleemi, M. A.,Mellander, L.,Ashraf, R. N.,Hanson, L. A. Changes in feeding patterns affect growth in children } \\
0-24 \text { months of age living in socioeconomically different areas of Lahore, Pakistan. Adv Exp Med Biol.2002;503:49-56. }\end{array}$ & Country \\
\hline 635 & $\begin{array}{l}\text { Zaman,S.,Ashraf,R. N.,Martines,J. Training in complementary feeding counselling of healthcare workers and its influence on } \\
\text { maternal behaviours and child growth: a cluster-randomized controlled trial in Lahore, Pakistan. J Health Popul } \\
\text { Nutr.2008;26:210-22. }\end{array}$ & $\begin{array}{l}\text { IV, } \\
\text { Country }\end{array}$ \\
\hline 636 & $\begin{array}{l}\text { Zavaleta,N.,Kvistgaard,A. S.,Graverholt,G.,Respicio,G.,Guija,H.,Valencia,N.,Lonnerdal,B. Efficacy of an MFGM-enriched } \\
\text { complementary food in diarrhea, anemia, and micronutrient status in infants. J Pediatr Gastroenterol Nutr.2011;53:561-8. }\end{array}$ & DV \\
\hline 637 & $\begin{array}{l}\text { Zhang,J.,Shi,L.,Chen,D. F.,Wang,J.,Wang,Y. Effectiveness of an educational intervention to improve child feeding practices and } \\
\text { growth in rural China: updated results at } 18 \text { months of age. Matern Child Nutr.2013;9:118-29. }\end{array}$ & IV \\
\hline 638 & $\begin{array}{l}\text { Zhu, B.,Zhang, J.,Qiu, L.,Binns, C.,Shao, J.,Zhao, Y.,Zhao, Z. Breastfeeding Rates and Growth Charts--the Zhejiang Infant } \\
\text { Feeding Trial. Int J Environ Res Public Health.2015;12:7337-47. }\end{array}$ & IV, DV \\
\hline 639 & $\begin{array}{l}\text { Ziegler, E. E.,Fields, D. A.,Chernausek, S. D.,Steenhout, P.,Grathwohl, D.,Jeter, J. M.,Nelson, S. E.,Haschke, F. Adequacy of } \\
\text { Infant Formula With Protein Content of } 1.6 \text { g/100 kcal for Infants Between } 3 \text { and } 12 \text { Months. J Pediatr Gastroenterol } \\
\text { Nutr.2015;61:596-603. }\end{array}$ & IV \\
\hline 640 & $\begin{array}{l}\text { Ziegler,E. E.,Fomon,S. J.,Nelson,S. E.,Rebouche,C. J.,Edwards,B. B.,Rogers,R. R.,Lehman,L. J. Cow milk feeding in infancy: } \\
\text { further observations on blood loss from the gastrointestinal tract. J Pediatr.1990;116:11-8. }\end{array}$ & IV, DV \\
\hline 641 & $\begin{array}{l}\text { Zive, M. M.,McKay, H.,Frank-Spohrer, G. C.,Broyles, S. L.,Nelson, J. A.,Nader, P. R. Infant-feeding practices and adiposity in 4-y- } \\
\text { old Anglo- and Mexican-Americans. Am J Clin Nutr.1992;55:1104-8. }\end{array}$ & Design \\
\hline 642 & $\begin{array}{l}\text { Zutavern, A.,Brockow, I.,Schaaf, B.,von Berg, A.,Diez, U.,Borte, M.,Kraemer, U.,Herbarth, O.,Behrendt, H.,Wichmann, H. } \\
\text { E.,Heinrich, J. Timing of solid food introduction in relation to eczema, asthma, allergic rhinitis, and food and inhalant sensitization } \\
\text { at the age of } 6 \text { years: results from the prospective birth cohort study LISA. Pediatrics.2008;121:e44-52. }\end{array}$ & DV \\
\hline
\end{tabular}

1. 
${ }^{1}$ Abbreviations: DV- Dependent variable; IV- Independent variable/exposure/intervention 


\section{APPENDIX}

This table describes the characteristics of included studies in alphabetical order of first author's last name.

\section{Supplemental Table S1. Description of studies examining types and amounts of complementary foods and beverages consumed and growth, size, and body composition.}

\begin{tabular}{|c|c|c|c|}
\hline Study & Intervention/Exposures & Outcomes & Confounders \& Limitations \\
\hline $\begin{array}{l}\text { Abraham, } 2012 \\
\text { Prospective Cohort Study; Scotland } \\
\text { Sample Size: } \\
\text { Baseline N: } 5,217 \\
\text { Analytic N: } 4,493 \\
\text { Attrition: } 13.9 \% \\
\text { Power Analysis: NR } \\
\text { Sex: } \\
\text { NR } \\
\text { Race/Ethnicity: } \\
\text { 4\% non-white ethnic group (Bradshaw, 2007) } \\
\text { Background Diet: } \\
\text { BF at 45-48mo: } 61.0 \% \text { ever BF, 39.0\% never } \\
\text { BF } \\
\text { Infants in the negative pattern: } 69 \% \text { ever BF; } \\
\text { started CFB at 0-3mo (20\%), 4-5mo (64\%), } \\
\text { and 6-10mo (16\%) } \\
\text { Infants in the positive pattern: } 50 \% \text { ever BF; } \\
\text { started CFB at 0-3mo (12\%), 4-5mo (69\%), } \\
\text { and 6-10mo (20\%) }\end{array}$ & $\begin{array}{l}\text { Two dietary patterns were } \\
\text { identified at 19-24mo using } \\
\text { cluster analysis, and each infant } \\
\text { was classified by cluster } \\
\text { membership: } \\
\text { Negative pattern: low fruit, } \\
\text { vegetable; high sweets, crisps, } \\
\text { soft drinks, snacking } \\
\text { Positive pattern: high fruit, } \\
\text { vegetable; low snacking } \\
\text { Age:0-24mo } \\
\text { Assessment Methods } \\
\text { Cluster analysis of survey at 19- } \\
24 \text { mo }\end{array}$ & $\begin{array}{l}\text { Weight status } \\
\text { Age: } 45-48 m o \\
\text { Assessment Methods } \\
\text { Weight status: frequency of } \\
\text { overweight/obese based on BMIZ } \\
\text { >1.04; not overweight/obese } \leq \\
1.04 \text { (UK } 1990 \text { ref. curves); } \\
\text { methods used to obtain weight } \\
\text { and height NR }\end{array}$ & $\begin{array}{l}\text { SES: } X \\
\text { Birth size: } X \\
\text { Limitations: } \\
\text { Cannot determine whether groups } \\
\text { were similar at baseline on key } \\
\text { characteristics; Key confounders } \\
\text { from the analytic framework were NR } \\
\text { or adjusted for in analyses including } \\
\text { sex, race/ethnicity, maternal age, or } \\
\text { birth size/gestational age; Cannot } \\
\text { determine if outcome assessors } \\
\text { were blinded, primary interviewers } \\
\text { were unblinded } \\
\text { Other: IV/Exposure was self-report; } \\
\text { Bradshaw, } 2007 \text { summarizes Sweep } \\
1 \text { baseline characteristics }\end{array}$ \\
\hline $\begin{array}{l}\text { Almquist-Tangen, } 2013 \\
\text { Prospective Cohort Study; Sweden } \\
\text { Sample Size: } \\
\text { Baseline N: } 2,666 \\
\text { Analytic N at } 12 \mathrm{mo}: 2,404 \\
\text { Analytic N at } 18 \mathrm{mo}: 2,241 \\
\text { Attrition at } 12 \mathrm{mo}: 9.8 \% \\
\text { Attrition at } 18 \mathrm{mo}: 15.9 \%\end{array}$ & $\begin{array}{l}\text { Milk cereal drink (MCD) vs. } \\
\text { porridge vs. semi-solids } \\
\text { MCD (68kcal/100mL) defined as } \\
\text { a soup-like liquid offered in a } \\
\text { bottle containing: } 1.8 \mathrm{~g} \text { protein, } \\
8.7 \mathrm{~g} \text { CHO and } 2.9 \mathrm{~g} \text { fat, fortified } \\
\text { with calcium, Fe, } \mathrm{n} \text {, iodine and } \\
\text { vitamins } \mathrm{A}, \mathrm{D}, \mathrm{E}, \mathrm{C} \text {, thiamine, } \\
\text { niacin, } \mathrm{B} 6 \text { folic acid, } \mathrm{B} 12 \text { and }\end{array}$ & $\begin{array}{l}\text { Outcomes: } \\
\text { Weight status } \\
\text { Age: } 12 \mathrm{mo}, 18 \mathrm{mo} \\
\text { Assessment Methods } \\
\text { Weight status: "high BMI" defined } \\
\text { as 1SD above study population; } \\
\text { BMI calculated from measured } \\
\text { weight (digital scale) and height } \\
\text { (stadiometer) }\end{array}$ & $\begin{array}{l}\text { Confounders accounted for: } \\
\text { Education: } X \\
\text { SES: } \\
\text { Sex: } X \\
\text { Maternal age: } \\
\text { Race/ethnicity: } \\
\text { Feeding practices: } \\
\text { Birth size: } X\end{array}$ \\
\hline
\end{tabular}




\begin{tabular}{|c|c|c|c|}
\hline $\begin{array}{l}\text { Power Analysis: NR } \\
\text { Sex: } \\
\text { 49.4\% female } \\
\text { Race/Ethnicity: } \\
\text { NR } \\
\text { Background Diet: } \\
\text { At } 4 \mathrm{mo}: 78.7 \% \text { BF, } 74.4 \% \text { EBF; } 21.3 \% \text { FF; } \\
4.3 \% \text { MF (BF and FF); At } 6 \text { mo, } 58.3 \% \text { BF; } \\
1.6 \% \text { EBF }\end{array}$ & $\begin{array}{l}\text { pantothenic acid; Porridge and } \\
\text { semi-solids not defined } \\
\text { Age:18mo } \\
\text { Assessment Methods } \\
\text { Y/N consumption of CFB at } 6 \mathrm{mo}\end{array}$ & & $\begin{array}{l}\text { Gestational age: } X \\
\text { Other: maternal obesity; paternal } \\
\text { obesity; paternal education; maternal } \\
\text { smoking; BMI at 1, 4, and } 6 \text { mo. } \\
\text { Limitations: } \\
\text { Cannot determine whether groups } \\
\text { were similar at baseline on key } \\
\text { characteristics; Cannot determine } \\
\text { reliability/validity of survey items; Did } \\
\text { not adjust for potential key } \\
\text { confounders (SES, race/ethnicity, } \\
\text { feeding practices) }\end{array}$ \\
\hline $\begin{array}{l}\text { Ay, } 2008 \\
\text { Prospective Cohort Study; The Netherlands } \\
\text { Sample Size: } \\
\text { Baseline N: } 1232 \\
\text { Analytic N: } 1012 \\
\text { Attrition: } 17.9 \% \\
\text { Power Analysis/Sample Size Calculation: NR } \\
\text { Sex: } \\
48.2 \% \text { Female } \\
\text { Race/Ethnicity: } \\
100 \% \text { "Dutch ethnicity" } \\
\text { Background Diet: } \\
90 \% \text { ever BF, duration of BF }=\sim 5 \mathrm{mo}\end{array}$ & $\begin{array}{l}\text { Age of CFB introduction: }<5 \text { mo or } \\
>5 \text { mo } \\
\text { CFB: Fruit snack } \\
\text { Age: } 2,6 \text {, and } 12 \text { mo } \\
\text { Assessment Methods: } \\
\text { Caregiver questionnaire }\end{array}$ & $\begin{array}{l}\text { Outcomes: } \\
\text { Body composition (Adiposity) } \\
\text { Age: } 24 \text { mo } \\
\text { Assessment Methods: } \\
\text { Body composition: sum of skinfold } \\
\text { thickness (biceps, triceps, } \\
\text { suprailiacal, subscapular) } \\
\text { measured by study personnel } \\
\text { using calipers }\end{array}$ & $\begin{array}{l}\text { Confounders accounted for: } \\
\text { Education: } X \\
\text { Sex: } X \\
\text { Maternal age: } X \\
\text { Gestational age: } X \\
\text { Other: Smoking_ } \\
\text { Limitations: } \\
\text { Cannot determine whether groups } \\
\text { were similar at baseline on key } \\
\text { characteristics; Cannot determine } \\
\text { whether outcome assessors were } \\
\text { blinded; Did not adjust for any key } \\
\text { confounders (SES, } \\
\text { race/ethnicity/feeding practices, birth } \\
\text { size) }\end{array}$ \\
\hline $\begin{array}{l}\text { Baird, } 2008 \\
\text { Prospective Cohort Study; United Kingdom } \\
\text { Sample Size: } \\
\text { Baseline } N=1,973 \\
\text { Analytic } N=1,740 \\
\text { Attrition }=11.8 \% \\
\text { Power Analysis and Sufficient Sample Size: } \\
\text { NR }\end{array}$ & $\begin{array}{l}\text { Two dietary patterns were } \\
\text { identified at 6mo using principal } \\
\text { component analysis, and each } \\
\text { infant received a score for } \\
\text { adherence to the pattern: } \\
\text { Infant Guidelines: high frequency } \\
\text { of consumption of vegetables, } \\
\text { fruit, meat, fish, home-prepared } \\
\text { foods, breast milk; low frequency }\end{array}$ & $\begin{array}{l}\text { Outcomes: } \\
\text { Body composition; Weight; } \\
\text { Length } \\
\text { Age: Birth, 6mo, 12mo, 0-6mo; 6- } \\
12 \mathrm{mo} \\
\text { Assessment Methods } \\
\text { Body composition: triceps and } \\
\text { subscapular skinfold calipers; }\end{array}$ & $\begin{array}{l}\text { Confounders accounted for: } \\
\text { Education: } X \\
\text { Sex: } X \\
\text { Other: Parity; Smoking } \\
\text { Limitations: } \\
\text { Cannot determine whether groups } \\
\text { were similar at baseline; Unclear } \\
\text { whether outcome assessors were } \\
\text { blinded to the infants' feeding }\end{array}$ \\
\hline
\end{tabular}




\begin{tabular}{|c|c|c|c|}
\hline $\begin{array}{l}\text { Sex: } \\
\text { 46.9\% female } \\
\text { Race/Ethnicity: } \\
\text { 94\% white } \\
\text { Background Diet: } \\
\text { 0-6mo: } 7.5 \% \text { BF; } ~ 21 \% \mathrm{FF}, \sim 71.5 \% \mathrm{MF} \\
\text { combination of BF and FF assessed via } \\
\text { caregiver-report at } 6 \mathrm{mo}\end{array}$ & $\begin{array}{l}\text { of consumption of commercial } \\
\text { baby foods in jars and formula } \\
\text { Adult Foods: high frequency of } \\
\text { consumption of bread, savory } \\
\text { snacks, biscuits, squash, } \\
\text { breakfast cereals, and crisps; low } \\
\text { frequency of breast milk, baby } \\
\text { rice, and cooked and canned fruit } \\
\text { Age:12mo } \\
\text { Assessment Methods } \\
\text { Timing: Maternal report } \\
\text { Type: FFQ over 7d at } 6 \text { mo; FFQ } \\
\text { over } 28 d \text { at } 12 \text { mo; Dietary } \\
\text { patterns identified by PCA }\end{array}$ & $\begin{array}{l}\text { crude and thickness SD score } \\
\text { from 0-6mo and 6-12mo- } \\
\text { Weight: digital scale; crude and } \\
\text { change in weight SD score from } \\
0-6 \mathrm{mo} \text { and } 6-12 \mathrm{mo} \\
\text { Length: infantometer; crude and } \\
\text { change in length SD score from } \\
0-6 \mathrm{mo} \text { and } 6-12 \mathrm{mo}\end{array}$ & $\begin{array}{l}\text { histories; Did not adjust for potential } \\
\text { key confounders (SES, maternal } \\
\text { age, race/ethnicity, feeding } \\
\text { practices, birth size, gestational age) } \\
\text { BF duration and infant diet was } \\
\text { retrospectively self-reported by } \\
\text { mothers at } 6 \text { and } 12 \text { mo, thus may } \\
\text { have been biased; ethnic minorities } \\
\text { were underrepresented in this } \\
\text { sample. }\end{array}$ \\
\hline $\begin{array}{l}\text { Barton, } 2002 \\
\text { Prospective Cohort Study; United States } \\
\text { Sample Size: } \\
\text { Baseline } N=52 \\
\text { Analytic } N=52 \\
\text { Attrition }=0 \% \\
\text { Power Analysis and Sufficient Sample Size: } \\
\text { NR } \\
\text { Sex: } \\
\text { NR } \\
\frac{\text { Race/Ethnicity: }}{N R} \\
\text { Background Diet: } \\
46 \% \text { BF, } 54 \% \text { FF at birth } \\
33 \% \text { BF, } 67 \% \text { FF at 1-2mo } \\
83 \% \text { received CFB }<4 \mathrm{mo}\end{array}$ & $\begin{array}{l}\text { Two dietary patterns were } \\
\text { observed in infants based on } \\
\text { intake before or at 4-6mo: } \\
\text { Inappropriate foods: home- } \\
\text { prepared mashed potatoes and } \\
\text { gravy, green beans with fat-back, } \\
\text { pork, bacon, steak, high-sugar } \\
\text { high-fat puddings, desserts, soda, } \\
\text { and juice >80z/d } \\
\text { Appropriate foods: Parent- } \\
\text { prepared solids w/o extra fat, salt, } \\
\text { sugar } \\
\text { Age:4-6mo } \\
\text { Assessment Methods } \\
\text { Caregiver report }\end{array}$ & $\begin{array}{l}\text { Outcomes: } \\
\text { Weight, length, HC } \\
\text { Age: 1-2mo; 4-6mo } \\
\text { Assessment Methods } \\
\text { Weight: measured by study } \\
\text { personnel on balance-beam scale } \\
\text { Length: measured by trained } \\
\text { personnel, on standard length } \\
\text { board } \\
\text { HC: measured by study personnel } \\
\text { with nonfabric measuring tape_ }\end{array}$ & $\begin{array}{l}\text { Confounders accounted for: } \\
\text { Other: NR } \\
\text { Limitations: } \\
\text { Cannot determine whether groups } \\
\text { differed at baseline on key } \\
\text { characteristics; Cannot determine } \\
\text { whether outcome assessors were } \\
\text { blinded; Length of follow-up varied } \\
\text { from } 4 \text { to } 6 \text { mo of age; Cannot } \\
\text { determined validity/reliability of } \\
\text { measures used to assess outcomes; } \\
\text { Did not adjust for any potential key } \\
\text { confounders (including education, } \\
\text { SES, sex, maternal age, } \\
\text { race/ethnicity, feeding practices, } \\
\text { birth size, gestational age) } \\
\text { Did not adjust for baseline values } \\
\text { though weight/length at } 1-2 \text { mo was } \\
\text { similar between groups; Groups } \\
\text { were unbalanced (40 infants in the } \\
\text { CFB <4mo group vs. } 8 \text { infants in the } \\
>4 \text { mo group). }\end{array}$ \\
\hline
\end{tabular}




\begin{tabular}{|c|c|c|c|}
\hline $\begin{array}{l}\text { Bell, } 2013 \\
\text { Prospective Cohort Study; Australia } \\
\text { Sample Size: } \\
\text { Baseline } N=552 \\
\text { Analytic } N=493 \\
\text { Attrition = } 10.7 \% \\
\text { Power Analysis: NR } \\
\text { Sex: } \\
54 \% \text { female } \\
\text { Race/Ethnicity: } \\
\text { NR } \\
\text { Background Diet: } \\
3 \% \text { never BF, } 34 \% \text { BF>6 mo, } 29 \% \text { BF } 6-12 \\
\text { mo, } 29 \% \text { BF>12 mo, } 6 \% \text { missing } \\
\text { Age of introduction to solids: } 20.9 \text { wk } \\
\text { (SD=5.1) }\end{array}$ & $\begin{array}{l}\text { Four dietary patterns were } \\
\text { identified at 13-16mo using } \\
\text { principal component analysis, and } \\
\text { each infant received a score for } \\
\text { adherence to the pattern: } \\
\text { Core: fruit, grains, nonwhite } \\
\text { bread, vegetables, cheese, eggs, } \\
\text { nuts and seeds } \\
\text { Basic combination: basic core + } \\
\text { non-core w/o fruit or vegetables } \\
\text { Basic core: white bread, milk } \\
\text { Non-core: spreads, juice, ice- } \\
\text { cream } \\
\text { Age:13-16mo } \\
\text { Assessment Methods } \\
3 d \text { multiple-pass } 24 h r \text { recalls (2d } \\
\text { week, 1d weekend); Dietary } \\
\text { patterns identified by PCA }\end{array}$ & $\begin{array}{l}\text { Outcomes: } \\
\text { BMIZ } \\
\text { Age: } 24 m o \\
\text { Assessment Methods } \\
\text { Body composition: age and sex- } \\
\text { specific BMIZ calculated from } \\
\text { measured weight/height } \\
\text { (measured by trained personnel, } \\
\text { physicians, nurses without shoes } \\
\text { or garments) }\end{array}$ & $\begin{array}{l}\text { Confounders accounted for: } \\
\text { Education: X } \\
\text { SES: X (SEIFA decile) } \\
\text { Sex: X } \\
\text { Maternal age: X } \\
\text { Feeding practices: X } \\
\text { Other: smoking status, marital } \\
\text { status, weight status, parity, child } \\
\text { age, age of introduction to solids } \\
\text { Limitations: } \\
\text { Cannot determine whether groups } \\
\text { differed at baseline on key } \\
\text { characteristics; Cannot detrmined } \\
\text { wheter outcome assessors were } \\
\text { blinded; Cannot determine reliability } \\
\text { of outcome assessment, } 17 \% \text { of } \\
\text { outcomes measured by general } \\
\text { practitioners or child health nurses, } \\
\text { not study staff; Did not adjust for } \\
\text { birth size, gestational age, or } \\
\text { race/ethnicity } \\
\text { Mothers may have reported more } \\
\text { favorable dietary intakes (highly } \\
\text { educated sample who may have } \\
\text { greater knowledge of dietary } \\
\text { recommendations) }\end{array}$ \\
\hline
\end{tabular}




\begin{tabular}{|c|c|c|c|}
\hline $\begin{array}{l}\text { Cantoral, } 2016 \\
\text { Prospective Cohort Study; Mexico } \\
\text { Sample Size: } \\
\text { Baseline N: } 622 \text { (enrolled in F/U) } \\
\text { Analytic N: } 227 \\
\text { Attrition: } ~ 64 \% \\
\text { Power Analysis and Sufficient Sample Size: } \\
\text { NR } \\
\text { Sex: } \\
54 \% \text { female } \\
\text { Race/Ethnicity: } \\
\text { NR } \\
\text { Background Diet: } \\
31 \% \text { at least partial BF; } 73 \% \text { introduced to } \\
\text { SSB <12mo }\end{array}$ & $\begin{array}{l}\text { Age of CFB introduction: } \leq 12 \mathrm{mo} \\
\text { vs }>12 \mathrm{mo} \\
\text { CFB: SSB: sum of daily intake of } \\
\text { soda, commercial fruit drinks, } \\
\text { flavored water with sugar; Not } \\
\text { including natural fruit or vegetable } \\
\text { juice } \\
\text { Age: } 12 \mathrm{mo} \text {; every } 6 \mathrm{mo} \text { until } 5 \mathrm{y} \text {; at } \\
8-14 \mathrm{y} \\
\text { Assessment Methods: } \\
\text { 116-item FFQ }\end{array}$ & $\begin{array}{l}\text { Weight status; WC } \\
\text { Age: } 8-14 y \\
\text { Assessment Methods: } \\
\text { Weight status: risk of obesity } \\
\text { classified as BMI>2 SD of } z- \\
\text { score; BMI from measured weight } \\
\text { (digital scale to } 0.1 \mathrm{~kg} \text { ) and height } \\
\text { (stadiometer to } 0.1 \mathrm{~cm} \text { ) } \\
\text { WC: measuring tape to } 0.1 \mathrm{~cm} \text { for } \\
\text { abdominal obesity: WC } \geq 90 \text { th } \\
\text { \%tile }\end{array}$ & $\begin{array}{l}\text { Confounders accounted for: } \\
\text { SES: } X \\
\text { Sex: } X \\
\text { Feeding practices: } X \\
\text { Other: non-SSB intake, TV watching, } \\
\text { physical activity, maternal obesity at } \\
12 \text { mo post-partum. } \\
\text { Limitations: } \\
\text { Cannot determine whether groups } \\
\text { differed at baseline on key } \\
\text { characteristics; Cannot determine if } \\
\text { outcome assessors were blinded; } \\
\text { Did not account for high attrition rate; } \\
\text { Did not adjust for key confounders of } \\
\text { education, maternal age, } \\
\text { race/ethnicity, birth size or } \\
\text { gestational age } \\
\text { Risk for measurement error } \\
\text { associated with FFQ; Assumes that } \\
\text { SSB intake was constant during the } \\
\text { months evaluated on FFQ }\end{array}$ \\
\hline $\begin{array}{l}\text { Carruth, } 2000 \\
\text { Prospective Cohort Study; United States } \\
\text { Sample Size: } \\
\text { Baseline } N=98 \\
\text { Analytic } N=94 \\
\text { Attrition }=4.1 \% \\
\text { Power Analysis and Sufficient Sample Size: } \\
\text { Use of an incomplete block design } \\
\text { maintained statistical power } \\
\text { Sex: } \\
48.0 \% \text { female (Skinner, 1997) } \\
\text { Race/Ethnicity: } \\
100 \% \text { White } \\
\text { Background Diet: } \\
33 \% \text { any BF, 33\% EBF at } 4 \mathrm{mo}, 33 \% \mathrm{MF} \text { at } \\
4 \mathrm{mo} ; 12 \% \text { EBF at } 6 \mathrm{mo}\end{array}$ & $\begin{array}{l}\text { Food cluster: yes/no if any meats, } \\
\text { mixed foods or table foods } \\
\text { Vegetables: yes/no } \\
\text { CFB: } 1 \text { or more foods including } \\
\text { cereal, juice, fruits, vegetables, } \\
\text { meat, mixed food, and table } \\
\text { foods; Infant could still be BF or } \\
\text { FF with CFB; Mean age of } \\
\text { introduction of cereal }=4.0 \mathrm{mo}, \\
\text { juice }=4.5 \mathrm{mo} \text {, fruit }=5.0 \mathrm{mo}, \\
\text { vegetables }=5.5 \mathrm{mo}, \text { food cluster } \\
\text { (mixed foods, table foods, meat) } \\
=7.0 \mathrm{mo} \\
\text { Age: } 2,3,4,6,8,10,12,16,20 \text {, } \\
\text { and } 24 \mathrm{mo} \\
\text { Assessment Methods } \\
24 \mathrm{~h} \text { recall }\end{array}$ & $\begin{array}{l}\text { Weight change } \\
\text { Age: } 2-8 m o \\
\text { Assessment Methods } \\
\text { Weight slope: } \mathrm{kg} / \mathrm{mo} \text {; standard } \\
\text { protocol } \\
\text { Length slope: } \mathrm{cm} / \mathrm{mo} \text {; standard } \\
\text { protocol } \\
\text { Interview schedules were done } \\
\text { using an incomplete block design, } \\
\text { such that the number of times } \\
\text { measures were taken for each } \\
\text { infant } 3-5 \text { times from } 2 \text { to } 10 \mathrm{mo} \text {, } \\
\text { and } 2-4 \text { times from } 12 \text { to } 24 \mathrm{mo}\end{array}$ & $\begin{array}{l}\text { Confounders accounted for: } \\
\text { Sex: } X \\
\text { Other: Final model 2-8mo rate of } \\
\text { change weight: gender, length slope } \\
\text { Limitations: } \\
\text { Cannot determine whether groups } \\
\text { differed at baseline on key } \\
\text { characteristics; Cannot determine } \\
\text { whether outcome assessors were } \\
\text { blinded; Cannot determine adequacy } \\
\text { of statistical methods (prior versions } \\
\text { of regression models not described, } \\
\text { data not shown); Did not adjust for } \\
\text { potential key confounders } \\
\text { (education, SES, maternal age, } \\
\text { race/ethnicity, birth size, or } \\
\text { gestational age); Limited }\end{array}$ \\
\hline
\end{tabular}




\begin{tabular}{|c|c|c|c|}
\hline $\begin{array}{l}-64 \% \text { CFB by } 4 \mathrm{mo} \text {; Median age for } \\
\text { introducing CFB: cereal } 4.0 \text { (range } .50-6.5 \\
\text { mo), juice } 4.50 \text { ( } 1-11 \text { mo), fruit } 5.0(.50-8.2 \\
\text { mo), vegetables } 5.5 \text { ( } 1-7.7 \text { mo) and the food } \\
\text { cluster (mixed foods, table foods, meat) } 7.0 \\
(3-12 \text { mo) }\end{array}$ & & & $\begin{array}{l}\text { generalizability (small sample of } \\
\text { white middle- to upper class subjects } \\
\text { from TN); Results reports only age of } \\
\text { intro of vegetables and food cluster } \\
\text { remained as significant predictors in } \\
\text { rate of change in weight but age of } \\
\text { any foods not significant predictor in } \\
\text { weight gain } 12-24 m o ; \text { Unclear how } \\
\text { addition of cereal } \leq 4 \text { or }>4 \text { mo was } \\
\text { analyzed in relation to weight } \\
\text { outcomes_ }\end{array}$ \\
\hline $\begin{array}{l}\text { Dagnelie, } 1994 \\
\text { Prospective Cohort Study; The Netherlands } \\
\text { Sample Size: } \\
\text { Baseline N: } 110 \\
\text { Analytic N: } 106 \\
\text { Attrition: } 3.6 \% \\
\text { Power Analysis/Sample Size Calculation: NR } \\
\text { Sex: } \\
\text { R9.0\% Female } \\
\text { Race/Ethnicity: } \\
\text { 100\% White } \\
\text { Background Diet: } \\
\text { Macrobiotic: BF for } \sim 13 \mathrm{mo} \\
\text { Omnivorous: BF for } \sim 6.5 \mathrm{mo}\end{array}$ & $\begin{array}{l}\text { Two dietary patterns were } \\
\text { observed in infants based on diet } \\
\text { followed at weaning, 4-10mo: } \\
\text { Macrobiotic diet: Included } \\
\text { unpolished rice, pulses and } \\
\text { vegetables with a high fiber } \\
\text { content, small additions of } \\
\text { seaweeds, fermented foods, nuts, } \\
\text { seeds, and seasoned foods; } \\
\text { Avoided vitamin D supplements, } \\
\text { products of animal origin such as } \\
\text { meat and dairy product, fat/oil, } \\
\text { and fish. } \\
\text { Omnivorous diet: Not described } \\
\text { Age:4mo-18mo, each cohort } \\
\text { followed for } 6 \text { mo Assessment } \\
\text { Methods } \\
\text { Food record, 3d, weighed }\end{array}$ & $\begin{array}{l}\text { Weight status; Body composition; } \\
\text { Weight; Length; Circumferences } \\
\text { Age: } 4-18 \text { mo } \\
\text { Assessment Methods } \\
\text { Results in Dagnelie, } 1989 \\
\text { reported as velocities (units/year) } \\
\text { Weight, length, sitting height: } \\
\text { measured without clothing on } \\
\text { Seca scale; flexible steel tape; } \\
\text { used to obtain weight-for-length } \\
\text { Crown-heel length, crown-rump } \\
\text { length: supine infantometer (for } \\
\text { infants <2y) } \\
\text { HC, MUAC, biiliacal (pelvic) } \\
\text { width: plastic insertion tape; used } \\
\text { to obtain fat and muscle areas of } \\
\text { arm } \\
\text { Skinfold thickness: Triceps and } \\
\text { subscapular via caliper to } 0.2 \mathrm{~mm} \\
\text { Wasting: arm-muscle-area } \\
\text { calculated from MUAC and tricep } \\
\text { skinfold_ }\end{array}$ & $\begin{array}{l}\text { Confounders accounted for: } \\
\text { Education: X } \\
\text { Sex: } X \\
\text { Other: Birthweight self-reported; } \\
\text { unclear if adjusted for rickets } \\
\text { Limitations: } \\
\text { Strategy to recruit/allocate } \\
\text { participants was not similar across } \\
\text { groups; Groups differed at baseline } \\
\text { on birth weight and feeding practices } \\
\text { and cannot determine if these were } \\
\text { adjusted for in analyses; Cannot } \\
\text { determine the level of adherence to } \\
\text { macrobiotic diet, or omnivorous } \\
\text { control diet, as specific details } \\
\text { regarding diet not provided; Did not } \\
\text { adjust for potential key confounders } \\
\text { (SES, maternal age, race/ethnicity, } \\
\text { feeding practices, birth size, } \\
\text { gestational age; Cannot determine } \\
\text { when outcomes were assessed } \\
\\
\text { Growth deficit in macrobiotic infants } \\
\text { driven by the 8-14mo cohort, with } \\
\text { significantly lower triceps skinfold, } \\
\text { arm fat area, and lower growth rate, } \\
\text { relative to omnivorous infants. }\end{array}$ \\
\hline
\end{tabular}




\begin{tabular}{|c|c|c|c|}
\hline & & & $\begin{array}{l}\text { Combination of lack of energy and } \\
\text { protein may have caused gowth } \\
\text { retardation in weight and MUAC } \\
\text { Cannot determine if rickets and } \\
\text { vitamin D deficiency were adjusted } \\
\text { for as macrobiotic vs. omnivorous } \\
\text { infants had greater rates of both. }\end{array}$ \\
\hline $\begin{array}{l}\text { Davidsson, } 1996 \\
\text { Cross-Over Study; Scotland } \\
\text { Sample Size: } \\
\text { Baseline N: } 57 \\
\text { Analytic N: } 57 \\
\text { Attrition: } 0 \% \\
\text { Power Analysis and Sufficient Sample Size: } \\
\text { NR } \\
\frac{\text { Sex: }}{\sim 53 \% \text { Female }} \\
\frac{\text { Race/Ethnicity: }}{\text { NR }} \\
\text { Background Diet: } \\
100 \% \text { FF (CM, no soy) }\end{array}$ & $\begin{array}{l}\text { Cereal varied by fiber content for } \\
4 \text { wk: } \\
\text { Wheat/soy: } 8 \% \text { fiber (A) or } 1.8 \% \\
\text { fiber (B) } \\
\text { Wheat/milk: } 5.3 \% \text { fiber (C) or } 2 \% \\
\text { fiber (D) } \\
\text { Cereal ad lib ( } 10-60 \text { g servings); } \\
\text { Additional weaning foods were } \\
\text { provided upon request (apple } \\
\text { puree, apple juice, exotic fruit } \\
\text { juice, and maize puree); } \\
\text { Age: } 7-17 \text { wk } \\
\text { Assessment Methods } \\
\text { Cereal intake was quantified by } \\
\text { weighing the containers before } \\
\text { the start of the study and at each } \\
\text { visit to the homes every } 14 d\end{array}$ & $\begin{array}{l}\text { Weight; Length; Circumferences } \\
\text { Age: } 7-17 \text { wk } \\
\text { Assessment Methods } \\
\text { Weight, height, arm and chest } \\
\text { circumference in cm, and HC in } \\
\text { cm were measured monthly_ }\end{array}$ & $\begin{array}{l}\text { Confounders accounted for: } \\
\text { Other: NR } \\
\text { Limitations: } \\
\text { Cannot determine whether groups } \\
\text { differed at baseline on key } \\
\text { characteristics; Cannot determine if } \\
\text { outcome assessors or investigators } \\
\text { were blinded; Cannot determine } \\
\text { influence from intake of other } \\
\text { weaning foods provided; Adherence } \\
\text { not described; Cannot determine } \\
\text { relability/validity of outcome } \\
\text { assessment } \\
\text { Cross-over design but characteristics } \\
\text { not described. }\end{array}$ \\
\hline
\end{tabular}




\begin{tabular}{|c|c|c|c|}
\hline $\begin{array}{l}\text { de Silva, } 2007 \\
\text { Non-Randomized Controlled Trial; Sri Lanka } \\
\text { Sample Size: } \\
\text { Baseline N: } 182 \\
\text { Analytic N: } 152 \\
\text { Attrition: } 16.5 \% \\
\text { Power: NR } \\
\frac{\text { Sex: }}{\sim 62 \% \text { female }} \\
\text { Race/Ethnicity: } \\
\text { NR } \\
\text { Background Diet: } \\
\sim 22.9 \% \text { receiving formula } \\
\sim 75 \% \text { EBF for } 4 \mathrm{mo}\end{array}$ & $\begin{array}{l}\text { Intervention: home-based CFB } \\
\text { (containing } 110-130 \mathrm{kcal} / 100 \mathrm{ml}) \\
+ \text { recipes + mechanical blender } \\
\text { from } 4-12 \mathrm{mo} \\
\text { Control: CFB of mothers' choice } \\
\text { from } 4-12 \mathrm{mo} \\
\text { Age: } 8 \mathrm{mo} \\
\text { Assessment Methods } \\
\text { Maternal questionnaire and } \\
\text { interview }\end{array}$ & $\begin{array}{l}\text { Weight; Length } \\
\text { Age: 4-12mo } \\
\text { Assessment Methods } \\
\text { Weight: gain; measuerd via digital } \\
\text { scale monthly } \\
\text { Length: gain, measured via } \\
\text { standard infantometer monthly_ }\end{array}$ & $\begin{array}{l}\text { Confounders accounted for: } \\
\text { Education: X } \\
\text { SES: X } \\
\text { Maternal age: X } \\
\text { Birth size: X } \\
\text { Limitations: } \\
\text { Group allocation methods were not } \\
\text { described; Cannot determine } \\
\text { whether groups differed at baseline } \\
\text { on key characteristics; Cannot } \\
\text { determine if investigators and } \\
\text { outcome assessors were blinded; } \\
\text { Statistical methods were not } \\
\text { described; Cannot determine } \\
\text { validity/reliabiilty of outcome } \\
\text { assessment; Did not adjust for } \\
\text { potential key confounders (sex, } \\
\text { race/ethnicity, feeding practices } \\
\text { though \# of feeds identical, or } \\
\text { gestational age) } \\
\text { Influence of having the recipes and } \\
\text { blender available could be } \\
\text { concurrent IV/Exposure aside from } \\
\text { CFB itself; Race/ethnicity data was } \\
\text { lacking; information on maternal } \\
\text { health was lacking; data on z scores } \\
\text { for weight for age not adequately } \\
\text { presented_ }\end{array}$ \\
\hline $\begin{array}{l}\text { Dube, } 2010 \\
\text { Randomized Controlled Trial; Germany } \\
\text { Sample Size: } \\
\text { Baseline N: } 132 \\
\text { Analytic N : } 97 \\
\text { Attrition: } 26.6 \% \\
\text { Sample Size Calculation: } \mathrm{N}=74 \text { to detect a } \\
\text { 1SD difference in } \mathrm{Hb}\end{array}$ & $\begin{array}{l}\text { High Meat Group (HM): Received } \\
\text { commercial baby jars from } 4- \\
11 \text { mo with meat content of } 12 \% \\
\text { by weight (according to pediatric } \\
\text { guidelines); } 20 \mathrm{~g} / \mathrm{d} 4-7 \mathrm{mo}, 28.6 \mathrm{~g} / \mathrm{d} \\
8-10 \mathrm{mo} \\
\text { Low Meat Group (LM): Received } \\
\text { meals 4-11mo with meat content }\end{array}$ & $\begin{array}{l}\text { Weight } \\
\text { Age: } 4,7 \text {, and } 10 \text { mo } \\
\text { Assessment Methods } \\
\text { Weight and length were } \\
\text { measured at the local clinic_. }\end{array}$ & $\begin{array}{l}\text { Confounders accounted for: } \\
\text { Sex: } X \\
\text { Feeding practices: } X \\
\text { Birth size: All >2.5kg } \\
\text { Gestational age: All full-term } \\
\text { Limitations: }\end{array}$ \\
\hline
\end{tabular}




\begin{tabular}{|c|c|c|c|}
\hline 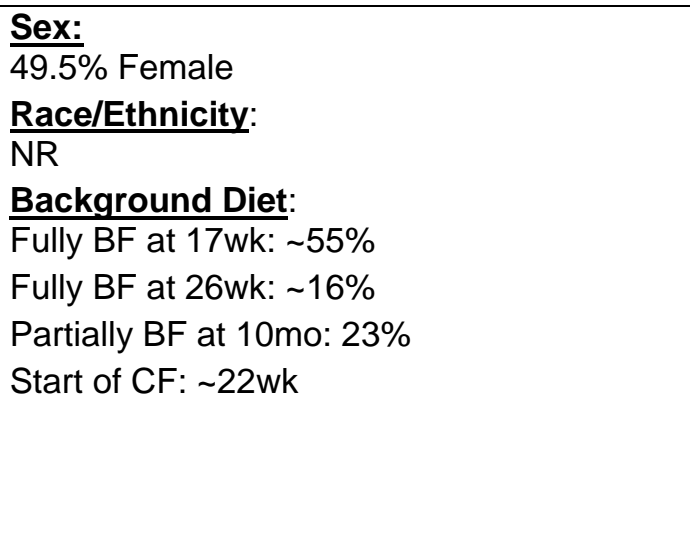 & $\begin{array}{l}8 \% \text { by weight (the lowest level of } \\
\text { EU law); } 15 \mathrm{~g} / \mathrm{d} 4-7 \mathrm{mo} ; 17.6 \mathrm{~g} / \mathrm{d} \\
8-10 \mathrm{mo} \\
50 \% \text { of jars contained beef, } 50 \% \\
\text { contained poultry; Parents were } \\
\text { advised to start CF by using the } \\
\text { study food between } 4-6 \mathrm{mo} \text {, and } \\
\text { to continue until } 10 \mathrm{~m} \text {, with a } \\
\text { frequency of } 1 \text { jar/d at least } 5 \\
\text { times/wk } \\
\text { Age: } 6 \mathrm{mo} \\
\text { Assessment Methods } \\
\text { Diet record }\end{array}$ & & $\begin{array}{l}\text { Did not assess the impact of high } \\
\text { loss to follow-up ( } 27 \%) \text {; Cannot } \\
\text { determine validity of outcome } \\
\text { measurement (weight NR) } \\
\text { The small difference between LM } \\
\text { (8\%) vs. HM (12\%) was } \\
\text { acknowledged as a limitation } \\
\text { Length was measured but not } \\
\text { reported in results_ }\end{array}$ \\
\hline 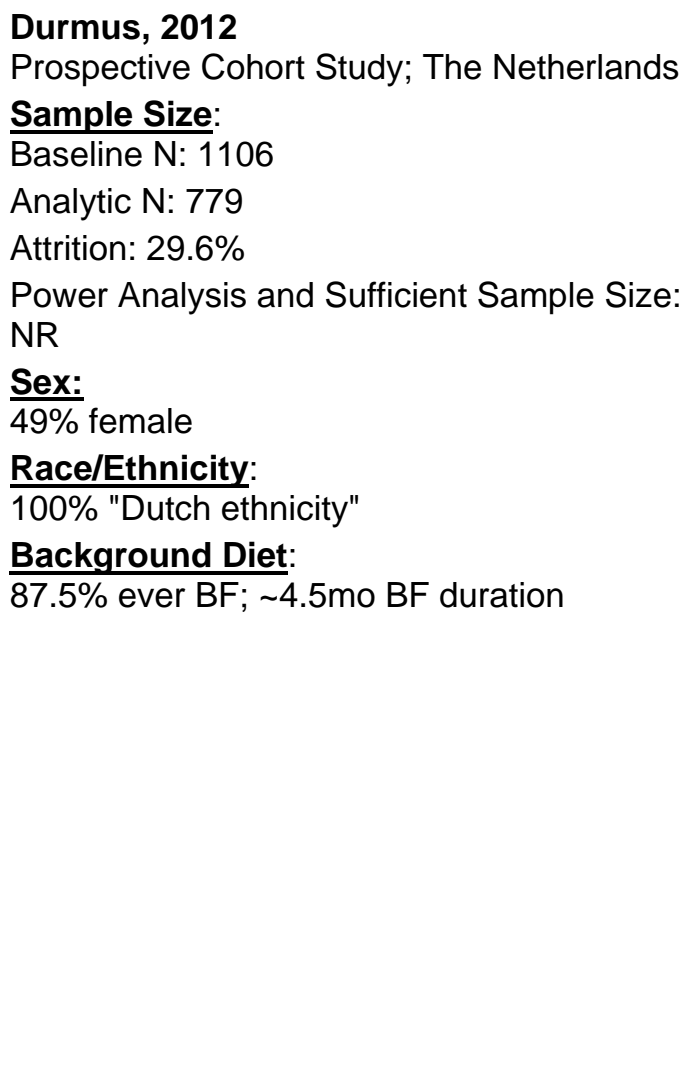 & $\begin{array}{l}\text { Fruit and/or vegetable snack first } \\
\text { given }(<4,4-5,>5 \mathrm{mo}) \\
\text { Age: } 2,6 \text {, and } 12 \mathrm{mo} \\
\text { Assessment Methods: } \\
\text { Caregiver questionnaire }\end{array}$ & $\begin{array}{l}\text { Body composition (Adiposity) } \\
\text { Age: } 6 \text { mo, } 24 \text { mo } \\
\text { Assessment Methods: } \\
\text { Body composition: } \\
\text { - Subcutaneous fat mass via } \\
\text { skinfold thickness (biceps, } \\
\text { triceps, suprailiacal, } \\
\text { subscapular) measured by } \\
\text { study personnel using } \\
\text { calipers }\end{array}$ & $\begin{array}{l}\text { Confounders accounted for: } \\
\text { Education: X } \\
\text { Sex: } X \\
\text { Feeding practices: } X \\
\text { Birth size: X (Birth weight) } \\
\text { Gestational age: X } \\
\text { Other: Maternal BMI, Smoking; } \\
\text { Parity; Current height; Observer. } \\
\text { Limitations: } \\
\text { Cannot determine whether groups } \\
\text { were similar at baseline on all key } \\
\text { characteristics; Cannot determine } \\
\text { whether outcome assessors were } \\
\text { blinded; Did not assess the impact of } \\
\text { high loss to follow-up ( } 27 \% \text { ); Did } \\
\text { not adjust for key confounders (SES, } \\
\text { maternal age, race/ethicity) } \\
\text { BF information only available in 78\% } \\
\text { of sample; CFB included only a fruit } \\
\text { or vegetable snack and other } \\
\text { products could have been } \\
\text { introduced; Homogenous, highly- } \\
\text { educated sample; } \\
\text { Limited generalizability }\end{array}$ \\
\hline
\end{tabular}




\begin{tabular}{|c|c|c|c|}
\hline $\begin{array}{l}\text { Durmus, } 2014 \\
\text { Prospective Cohort Study; The Netherlands } \\
\text { Sample Size: } \\
\text { Baseline N: } 6054 \\
\text { Analytic N: } 5063 \\
\text { Attrition: } 16.4 \% \\
\text { Power Analysis and Sufficient Sample Size: } \\
\text { NR } \\
\text { Sex: } \\
50.2 \% \text { female } \\
\text { Race/Ethnicity: } \\
100 \% \text { "Dutch ethnicity" } \\
\text { Background Diet: } \\
92.4 \% \text { ever BF; } 20.4 \% \text { EBF to } 4 \mathrm{mo}\end{array}$ & $\begin{array}{l}\text { Fruit and/or vegetable snack first } \\
\text { given }(<4,4-4.9, \geq 5 \mathrm{mo}) \\
\text { Age: } 2,6 \text {, and } 12 \mathrm{mo} \\
\text { Assessment Methods: } \\
\text { Caregiver questionnaire }\end{array}$ & $\begin{array}{l}\text { Outcomes: } \\
\text { Weight status; Body composition; } \\
\text { WC } \\
\text { Age: } 6 y \\
\text { Assessment Methods: } \\
\text { Weight status: risk of overweight } \\
\text { or obesity based on IOTF } \\
\text { categories for BMI } \\
\text { Body composition: } \\
\text { - Adiposity: total fat mass, } \\
\text { android-gynoid ratio (DXA) } \\
\text { BMl: calculated from } \\
\quad \text { measured height/weight } \\
\quad \text { (stadiometer/ mechanical } \\
\quad \text { scale) } \\
\text { Abdominal/WC: abdomial fat via } \\
\text { ultra-sound }\end{array}$ & $\begin{array}{l}\text { Confounders accounted for: } \\
\text { Education: } X \\
\text { Sex: } X \\
\text { Maternal age: X } \\
\text { Race/ethnicity: X } \\
\text { Birth size: X } \\
\text { Gestational age: X } \\
\text { Other: Child age, Child height; } \\
\text { Parity; Maternal BMI, Smoking; TV } \\
\text { watching_ } \\
\text { Limitations: } \\
\text { Cannot determine whether groups } \\
\text { were similar at baseline on all key } \\
\text { characteristics; Cannot determine } \\
\text { whether outcome assessors were } \\
\text { blinded; Did not adjust for key } \\
\text { confounders (SES or feeding } \\
\text { practices) } \\
\text { Did not collect information on BM } \\
\text { consumption or composition }\end{array}$ \\
\hline $\begin{array}{l}\text { Engelmann, } 1998 \\
\text { Randomized Controlled Trial; Denmark } \\
\text { Sample Size: } \\
\text { Baseline N: } 55 \\
\text { Analytic N: } 41 \\
\text { Attrition: } 25.5 \% \\
\text { Power Analysis/Sample Size Calculation: NR } \\
\text { Sex: } \\
29.3 \% \text { Female } \\
\text { Race/Ethnicity: } \\
\text { NR } \\
\text { Background Diet: } \\
100 \% \text { BF (for } \geq 1 / d) ; H M \text { consumed more } \\
\text { formula ( }=0.06) \text { than LM; LM consumed } \\
\text { more Fe-fortified gruel than HM ( } p=0.03 \text { ). } \\
\text { Fish, cow's milk, fruits, vegetables, and other } \\
\text { foods (NS) }\end{array}$ & $\begin{array}{l}\text { Low-meat group (LM): Received a } \\
\text { diet with } 10 \mathrm{~g} / \mathrm{d} \text { of meat } \\
\text { High-meat group (HM): Received } \\
\text { a diet with } 27 \mathrm{~g} / \mathrm{d} \text { of meat } \\
\text { Parents choose from } 7 \text { purees } \\
\text { containing vegetables and meat } \\
\text { (beef, pork, lamb, turkey, cod) } \\
\text { prepared in low- and high-meat } \\
\text { versions. All other foods were } \\
\text { served ad libitum. } \\
\text { Age: } 8-10 \text { mo } \\
\text { Assessment Methods } \\
\text { Food record, weighed 1/wk }\end{array}$ & $\begin{array}{l}\text { Outcomes: } \\
\text { Body composition; Weight; } \\
\text { Length; MUAC } \\
\text { Age: } 10 \text { mo } \\
\text { Assessment Methods } \\
\text { Body composition: triceps skinfold } \\
\text { via calipers } \\
\text { Weight: Electronic scale to 1g } \\
\text { Length (crown-heel): Electronic } \\
\text { measuring board to 0.1cm } \\
\text { MUAC: non-stretchable tape; _ }\end{array}$ & $\begin{array}{l}\text { Confounders accounted for: } \\
\text { Other: all full-term, >2.5kg; Baseline } \\
\text { growth measures NSD between } \\
\text { groups; birth weight and length } \\
\text { significantly higher in LMG } \\
\text { Limitations: } \\
\text { Cannot determine whether group } \\
\text { allocation was concealed; Groups } \\
\text { differed at baseline (varied in } \\
\text { consumption of formula and gruel) } \\
\text { and differences were not adjusted for } \\
\text { in analyses; Cannot determine } \\
\text { whether subjects or investigators } \\
\text { were blinded; Cannot determine } \\
\text { validity and reliability of outcome } \\
\text { assessment; Did not assess the } \\
\text { impact of high loss to follow-up } \\
\text { ( 26\%); Did not adjust analyses for }\end{array}$ \\
\hline
\end{tabular}




\begin{tabular}{|c|c|c|c|}
\hline 4600) & & & $\begin{array}{l}\text { potential key confounders } \\
\text { (education, SES, sex, feeding } \\
\text { practices, race/ethnicity, birth weight, } \\
\text { or gestational age) } \\
\text { Groups differed on birth weight and } \\
\text { length at baseline, and consumption } \\
\text { of formula and gruel, and these } \\
\text { differences were not controlled for in } \\
\text { the analyses. }\end{array}$ \\
\hline $\begin{array}{l}\text { Gaffney, } 2012 \\
\text { Prospective Cohort Study; United States } \\
\text { Sample Size: } \\
\text { Baseline } N=4902 \\
\text { Analytic } N=691 \\
\text { Attrition = 85.9\% } \\
\text { Power Analysis and Sufficient Sample Size: } \\
\text { NR } \\
\text { Sex: } \\
49.3 \% \text { Female } \\
\text { Race/Ethnicity: } \\
\text { NR } \\
\text { Background Diet: } \\
\text { BF intensity in late infancy: } 52.1 \% \text { low, } \\
24.3 \% \text { medium, } 23.6 \% \text { high }\end{array}$ & $\begin{array}{l}\text { Juice intake intensity according to } \\
\text { servings per } 2 \mathrm{~d} \text { : } \\
0 \text { juice/2d, } 1 \text { juice/2d, >1 juice/2d } \\
\text { Age:1, } 2,3,4,5,6,7,9,10 \text {, and } \\
12 \mathrm{mo} \\
\text { Assessment Methods } \\
\text { Maternal questionnaire }\end{array}$ & $\begin{array}{l}\text { WAZ } \\
\text { Age: } 12 \mathrm{mo} \\
\text { Assessment Methods } \\
\text { WAZ: maternal-report from recent } \\
\text { doctor visit; calculated age and } \\
\text { sex-specific } z \text { scores by CDC } \\
\text { standards. }\end{array}$ & $\begin{array}{l}\text { Confounders accounted for: } \\
\text { Education: } X \\
\text { SES: } X \\
\text { Maternal age: X } \\
\text { Race/ethnicity: X } \\
\text { Feeding practices: X } \\
\text { Birth size: X } \\
\text { Other: Mother's smoking status, } \\
\text { weight gain in pregnancy, pregravid } \\
\text { BMI } \\
\text { Limitations: } \\
\text { Cannot determine whether groups } \\
\text { were similar at baseline on key } \\
\text { characteristics; Cannot determine } \\
\text { reliability/validity of outcome } \\
\text { assessment and outcome assessors } \\
\text { were not blinded due to both feeding } \\
\text { and outcome data self-reported by } \\
\text { mothers; Did not assess the impact } \\
\text { of high loss to follow-up ( } 40 \%) ; \text { Did } \\
\text { not adjust analyses for potential } \\
\text { confounders (sex, gestational age) } \\
\text { Generalizability limited due to } \\
\text { sample not being representative } \\
\text { (Data not derived from a nationally } \\
\text { representative sample, } \\
\text { underrepresented minority groups; }\end{array}$ \\
\hline
\end{tabular}




\begin{tabular}{|c|c|c|c|}
\hline & & & $\begin{array}{l}\text { sample biased toward mothers with } \\
\text { more education and higher SES) }\end{array}$ \\
\hline $\begin{array}{l}\text { Garden, } 2011 \\
\text { Prospective Cohort Study; Australia } \\
\text { Sample Size: } \\
\text { Baseline N: } 616 \\
\text { Analytic N: } 362 \text { (339 WC) } \\
\text { Attrition: } 41.2 \% \text { (44.5\%) } \\
\text { Power Analysis and Sufficient Sample Size: } \\
\text { NR } \\
\text { Sex: } \\
\text { N:362 for BM: } 49.5 \% \text { female } \\
\text { N:339 for WC: } 48.7 \% \text { female } \\
\text { Race/Ethnicity: } \\
\text { N:362 for BMI: } 55 \% \text { Caucasian, } 8.8 \% \\
\text { European, 3.6\% Middle Eastern, } \\
5 \% \text { Indian 3.9\% Asian, } 23.8 \% \text { Undefined } \\
\text { N: } 339 \text { for WC: } \\
54.3 \% \text { Caucasian, 8.8\% European, 3.5\% } \\
\text { Middle Eastern, } \\
5 \% \text { Indian } 4.1 \% \text { Asian, } 24.2 \% \text { Undefined } \\
\text { Background Diet: } \\
\text { N:362 for BMl: } 41.7 \% \text { BF } \geq 6 \text { mo } \\
\text { N:339 for WC: } 42.2 \% \text { BF } \geq 6 \text { mo }\end{array}$ & $\begin{array}{l}\text { Quintiles of grams (g) and \% total } \\
\text { energy intake (\%kcal) from CFB } \\
\text { of core and extra foods at 18mo: } \\
\text { Dairy: combined milk and milk } \\
\text { products: yogurt, cheese, ice } \\
\text { cream, custard } \\
\text { Milk: skim, whole and evaporated } \\
\text { Fruit } \\
\text { Vegetables } \\
\text { Cereal: bread, pasta, rice, } \\
\text { breakfast cereals, etc. } \\
\text { Meats: chicken nuggets, ground } \\
\text { beef, beef sausages, ham, etc } \\
\text { Total extra foods: savory sauces, } \\
\text { fats, and oils } \\
\text { Non-milk beverages: juice, } \\
\text { cordial, fruit drinks and soft drinks } \\
\text { Sweetened drinks: cordial, fruit } \\
\text { drinks and soft drinks; } \\
\text { Fried potatoes } \\
\text { Salty snacks: potato crisps, } \\
\text { cheese snacks, corn chips } \\
\text { Confectionary: e.g., chocolate, } \\
\text { jellies, energy bars } \\
\text { Cereal-based products: e.g., } \\
\text { cookies, cakes, pies, buns } \\
\text { Age:18mo } \\
\text { Assessment Methods } \\
\text { Food record, 3d, weighed }\end{array}$ & $\begin{array}{l}\text { Body composition; WC } \\
\text { Age: } 8 y \\
\text { Assessment Methods } \\
\text { Body composition: BMI calculated } \\
\text { from measured weight and length } \\
\text { using } \mathrm{kg} / \mathrm{m} 2 \\
\text { Weight: electronic bathroom } \\
\text { scale; to } 1 \mathrm{~kg} \\
\text { Length: portable stadiometer to } \\
1 \mathrm{~cm} \\
\text { WC: flexible, steel tape below } \\
\text { costal border and iliac crest to } \\
0.1 \mathrm{~cm} \\
\text { Measurements made by study } \\
\text { nurses }\end{array}$ & $\begin{array}{l}\text { Confounders accounted for: } \\
\text { Education: } X \\
\text { Sex: } X \\
\text { Maternal age: X } \\
\text { Race/ethnicity: } X \\
\text { Feeding practices: } X \\
\text { Birth size: } X \\
\text { Gestational age:X } \\
\text { Other: Parent obesity; smoking; } \\
\text { daycare; n3 v. n6 group; Maternal } \\
\text { and Gestational age were removed } \\
\text { from model } \\
\text { Limitations: } \\
\text { Cannot determine whether groups } \\
\text { were similar on baseline } \\
\text { characteristics; Cannot determine } \\
\text { whether outcome assessors were } \\
\text { blinded; Did not account for high } \\
\text { attrition rate/lost to follow-up (22\%); } \\
\text { Did not adjust for potential key } \\
\text { confounders (SES) } \\
\text { Study was not powered to detect } \\
\text { differences in obesity outcomes; Did } \\
\text { not measure physical activity; } \\
\text { Did not calculate intake from total } \\
\text { core foods but calculated, analyzed, } \\
\text { and reported intake from total extra } \\
\text { foods }\end{array}$ \\
\hline
\end{tabular}




\begin{tabular}{|c|c|c|c|}
\hline 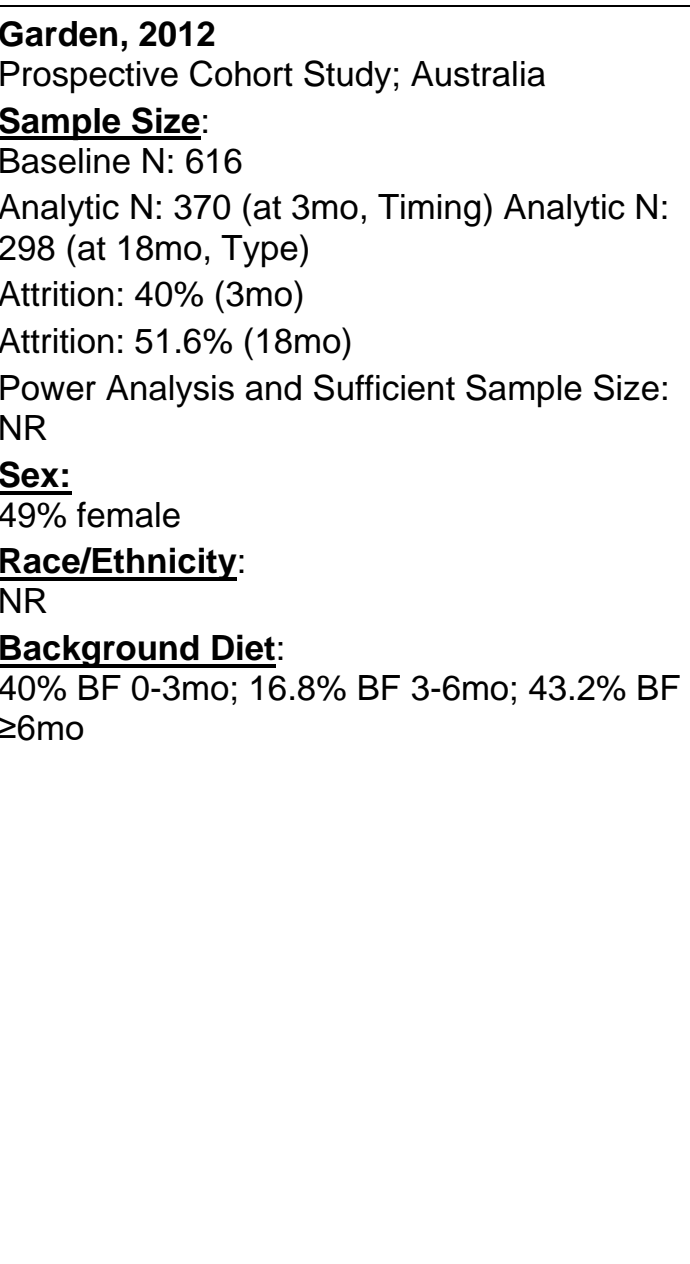 & $\begin{array}{l}\text { Grams (g) and \% total energy } \\
\text { intake (\%kcal) from CFB at 18mo: } \\
\text { Dairy: combined milk and milk } \\
\text { products: yogurt, cheese, ice } \\
\text { cream, custard } \\
\text { Milk: skim, whole and evaporated } \\
\text { Fruit } \\
\text { Vegetables } \\
\text { Cereal: bread, pasta, rice, } \\
\text { breakfast cereals, etc. } \\
\text { Meats: chicken nuggets, ground } \\
\text { beef, beef sausages, ham, etc. } \\
\text { Total extra foods: savory sauces, } \\
\text { fats, and oils } \\
\text { Non-milk beverages: juice, } \\
\text { cordial, fruit drinks and soft drinks } \\
\text { Sweetened drinks: cordial, fruit } \\
\text { drinks and soft drinks; } \\
\text { Fried potatoes } \\
\text { Salty snacks: potato crisps, } \\
\text { cheese snacks, corn chips } \\
\text { Confectionary: e.g., chocolate, } \\
\text { jellies, energy bars } \\
\text { Cereal-based products: e.g., } \\
\text { cookies, cakes, pies, buns } \\
\text { Age: 3mo; 18mo Assessment } \\
\text { Methods } \\
\text { Questionnaire; Food record, 3d, } \\
\text { weighed }\end{array}$ & $\begin{array}{l}\text { Body composition } \\
\text { Age: } 0-11.5 y \\
\text { Assessment Methods } \\
\text { Body composition: BMI trajectory } \\
\text { calculated in } \mathrm{kg} / \mathrm{m} 2 \text { based on } \\
\text { measured weight and height } \\
\text { (weight, electronic bathroom } \\
\text { scale to } 1 \mathrm{~kg} \text {; length: portable } \\
\text { stadiometer to } 1 \mathrm{~cm} \text { ); categorized } \\
\text { using CDC \%tile curves for BMI: } \\
\text { Normal: tracks at 50th } \\
\text { Early and Persistent: at } 75 \text { th at } 2 \mathrm{y} \\
\text { crossing to } 95 \text { th at } 11.5 \mathrm{y} \\
\text { Late Increase: tracks at } 50 \text { th at } \\
2 \mathrm{y} \text {; crossed to } 85 \text { th at } 8 \mathrm{y}, \text { and } \\
90 \text { th at } 11.5 \mathrm{y} \\
\text { Measurements made by study } \\
\text { nurses at } 1,3,6 \text {, and } 9 \mathrm{mo} \text {; every } \\
6 \mathrm{mo} \text { from } 9 \text { mo-5y, at } 8 \mathrm{y} \text {, at } 11.5 \mathrm{y} \\
\text { WC measured but NR }\end{array}$ & $\begin{array}{l}\text { Confounders accounted for: } \\
\text { Education: } X \\
\text { Sex: } X \\
\text { Race/ethnicity: X } \\
\text { Feeding practices: X } \\
\text { Other: n3 vs. n6 intervention group; } \\
\text { parent obesity; smoking } \\
\text { Limitations: } \\
\text { Cannot determine whether groups } \\
\text { were similar on baseline } \\
\text { characteristics; Cannot determine } \\
\text { whether outcome assessors were } \\
\text { blinded; Did not account for high } \\
\text { attrition rate/lost to follow-up (40\%); } \\
\text { Did not adjust for potential key } \\
\text { confounders (SES, maternal age, } \\
\text { birth size, gestational age) }\end{array}$ \\
\hline
\end{tabular}




\begin{tabular}{|c|c|c|c|}
\hline $\begin{array}{l}\text { Golley, } 2013 \\
\text { Prospective Cohort Study; United Kingdom } \\
\text { Sample Size: } \\
\text { Baseline N: 13,978 } \\
\text { Analytical N: 7y: 7834; 8y: } 7170 \\
\text { Attrition: 7y: 44\%; 8y: 48.7\% } \\
\text { Power: NR } \\
\text { Sex: } \\
\text { 48.3\% female } \\
\text { Race/Ethnicity: } \\
\text { NR } \\
\text { Background Diet: } \\
\text { Dietary pattern scores from FFQ collected at } \\
\text { 7y; CFUl scores were negatively associated } \\
\text { with a "processed" dietary pattern but } \\
\text { positively associated with a "health } \\
\text { conscious" dietary pattern }\end{array}$ & $\begin{array}{l}\text { Each infant received a } \\
\text { complementary feeding utility } \\
\text { index (CFUI) score at } 6 \text { mo, which } \\
\text { was derived and analyzed as a } \\
\text { continuous variable from } 14 \\
\text { components (BF duration, age of } \\
\text { introduction to solids, textured } \\
\text { foods, and minimizing ready- } \\
\text { made infant foods. Higher CFUI } \\
\text { scores reflected higher } \\
\text { adherence to CF guidelines. } \\
\text { Dietary patterns were not } \\
\text { analyzed in relation to growth } \\
\text { outcomes. } \\
\text { Age: 6mo } \\
\text { Assessment Methods } \\
\text { CFUI calculation from FFQ- } \\
\text { derived dietary patterns }\end{array}$ & $\begin{array}{l}\text { Outcomes: } \\
\text { Body composition; WC } \\
\text { Age: } 7.5 y \\
\text { Assessment Methods } \\
\text { Body composition: BMI calculated } \\
\text { from measured height/weight } \\
\text { (stadiometer/Tanita scale) } \\
\text { WC: flexible tape to the nearest } \\
1 \mathrm{~mm} \text {. }\end{array}$ & $\begin{array}{l}\text { Confounders accounted for: } \\
\text { Education: } X \\
\text { SES: } X \\
\text { Sex: } X \\
\text { Maternal age: } X \\
\text { Race/ethnicity: } X \\
\text { Feeding practices: X (CFUI score) } \\
\text { Birth size: } X \\
\text { Gestational age: } X \\
\text { Other: marital status, maternal } \\
\text { smoking, maternal weight status, } \\
\text { other children, singleton/twin and } \\
\text { stimulating in the home environment; } \\
\text { Model 2: height } \\
\text { Limitations: } \\
\text { Cannot determine validity/reliability } \\
\text { of assessment for exposure; Cannot } \\
\text { determine whether outcome } \\
\text { assessors were blinded; Did not } \\
\text { account for high attrition rate/lost to } \\
\text { follow-up (44\%) } \\
\text { Race/ethnicity NR in article } \\
\text { (collected in parent cohort) but } \\
\text { adjusted for analyses_. }\end{array}$ \\
\hline
\end{tabular}




\begin{tabular}{|c|c|c|c|}
\hline $\begin{array}{l}\text { Hertrampf, } 1990 \\
\text { Prospective Cohort Study; Chile } \\
\text { Sample Size: } \\
\text { Baseline N: } 239 \\
\text { Analytic N: } 189 \text { at } 4 \mathrm{mo} ; 187 \text { at } 12 \mathrm{mo} \\
\text { Attrition: } 20.9 \% \text { at } 4 \mathrm{mo} ; 21.7 \% \text { at } 12 \mathrm{mo} \\
\text { Power Analysis and Sufficient Sample Size: } \\
\text { NR } \\
\frac{\text { Sex: }}{\text { NR }} \\
\frac{\text { Race/Ethnicity: }}{100 \% \text { Hispanic }} \\
\text { Background Diet: } \\
\text { All were BF at 3mo } \\
\text { When BF stopped, infants fed non-fortified } \\
\text { whole cow's milk }\end{array}$ & $\begin{array}{l}\text { Fe-fortified cereal } \sim 3-6 \mathrm{mo}: \\
\text { received } 20 \mathrm{~g} / \mathrm{d} \text { at } 4 \mathrm{mo} \text { and } 40 \mathrm{~g} / \mathrm{d} \\
\text { at } 6 \mathrm{mo}(100 \mathrm{~g}: 360 \mathrm{kcal}, 11.6 \mathrm{~g} \\
\text { pro, } 0.3 \mathrm{~g} \text { fat, } 14 \mathrm{mg} \mathrm{Fe}) \\
\text { Control } 3-6 \mathrm{mo} \text { : routine CFB (at } \\
3 \mathrm{mo} \text {, fruit, cereal, juice; at } 4 \mathrm{mo} \text {, } \\
\text { veg and meat; at } 6 \mathrm{mo}, \text { legumes } \\
\text { and eggs) } \\
\text { Age:4-6mo } \\
\text { Assessment Methods } \\
\text { NR }\end{array}$ & $\begin{array}{l}\text { Weight } \\
\text { Age: } 8 \mathrm{mo}, 12 \mathrm{mo} \\
\text { Assessment Methods } \\
\text { Weight: weight/age adequacy as } \\
\% \text { median of NCHS standard for } \\
\text { weight/age ratio. }\end{array}$ & $\begin{array}{l}\text { Confounders accounted for: } \\
\text { NSD in birth weight, BF duration, } \\
\text { maternal age, or SES } \\
\text { Limitations: } \\
\text { Cannot determine group allocation } \\
\text { methods; Cannot determine whether } \\
\text { outcome assessors or investigators } \\
\text { were blinded; Participants were not } \\
\text { blinded to intervention status; } \\
\text { Cannot determine reliablity/validity of } \\
\text { outcome assessment (NR); Did not } \\
\text { account for high attrition rate } \\
\text { ( } 21 \%) \text {; Cannot determine adequacy } \\
\text { of statistical methods (lack of detail) }\end{array}$ \\
\hline $\begin{array}{l}\text { Hoffman, } 2004 \\
\text { Randomized Controlled Trial; United States } \\
\text { Sample Size: } \\
\text { Baseline N: } 55 \\
\text { Analytic N: } 51 \\
\text { Attrition: } 93 \% \\
\text { Sample Size Calculation/Power Analysis: } \\
\text { N:21 to detect a 1SD difference in visual } \\
\text { acuity, (stereoacuity, and blood lipids) at } \\
12 \mathrm{mo} \\
\text { Sex: } \\
\text { NR } \\
\text { Race/Ethnicity: } \\
\text { NR } \\
\text { Background Diet: } \\
\text { All EBF to } 9.7 m o \text { in control infants and to } \\
8.8 m o \text { in DHA-rich infants; } 65 \% \text { of control } \\
\text { infants, and } 80 \% \text { of DHA-rich infants were } \\
\text { weaned to IF before } 12 \mathrm{mo}\end{array}$ & $\begin{array}{l}\text { DHA-enriched CFB: receive } 1 \\
\text { jar/day of solid baby food, } \\
\text { enriched with DHA from egg-yolk, } \\
\text { from } 6 \text { to } 12 \mathrm{mo} \\
\text { Control CFB: receive } 1 \text { jar/day of } \\
\text { solid baby food from } 6 \text { to } 12 \mathrm{mo} \\
\text { CFB: solid baby food w/ and w/o } \\
\text { DHA from egg yolk; DHA-rich } \\
\text { food was } 2.3 \mathrm{~kJ} / \mathrm{g} \text { higher in } \\
\text { energy density than control food; } \\
216 \text { food jars in } 5 \text { varieties } \\
\text { (vegetable, cereal w/ fruit, fruit } \\
\text { custard) were shipped to } \\
\text { participants } \\
\text { Age:6-12mo } \\
\text { Assessment Methods } \\
\text { Baby food jars weighed to ensure } \\
\text { adherence and intake at } 1-2 \mathrm{mo}\end{array}$ & $\begin{array}{l}\text { Body composition; Weight; } \\
\text { Length; HC } \\
\text { Age: } 6,9 \text {, and } 12 \text { mo } \\
\text { Assessment Methods } \\
\text { Body composition: Skinfold z- } \\
\text { score } \\
\text { Weight: z-score } \\
\text { Length: z-score } \\
\text { HC: z-score } \\
\text { (Birch, 1998: Weight was } \\
\text { measured using a Healthometer } \\
\text { pediatric strain gauge scale } \\
\text { accurate to 1g. Length was } \\
\text { measured using Ellard Length } \\
\text { Boards accurate to 0.1cm. Head } \\
\text { circumference was measured } \\
\text { using a nonstretching tape } \\
\text { accurate to 0.1cm. Subscapular } \\
\text { and triceps fat deposition were }\end{array}$ & $\begin{array}{l}\text { Confounders accounted for: } \\
\text { Feeding practices: All EBF } \\
\text { Gestational age: All full-term } \\
\text { Limitations: } \\
\text { Cannot determine investigators or } \\
\text { outcome assessors were blinded }\end{array}$ \\
\hline
\end{tabular}




\begin{tabular}{|c|c|c|c|}
\hline & & $\begin{array}{l}\text { measured using a Lafayette skin } \\
\text { fold caliper accurate to } 1 \mathrm{~mm} \text { ) }\end{array}$ & \\
\hline $\begin{array}{l}\text { lannotti, } 2009 \\
\text { Prospective Cohort Study; Peru } \\
\text { Sample Size: } \\
\text { Baseline N: } 579 \\
\text { Analytic N: } 232 \\
\text { Attrition: } 59 \% \\
\text { Power Analysis: NR } \\
\text { Sex: } \\
49.1 \% \text { Female } \\
\text { Race/Ethnicity: } \\
\text { NR } \\
\text { Background Diet: } \\
\text { 92\% BF during 6-12mo }\end{array}$ & $\begin{array}{l}\text { Infants categorized as receiving } \\
\text { CFB or animal source foods } \\
\text { (meat, fish, egg, or milk) if the } \\
\text { mother reported consumption of } \\
\text { solid foods (cereal, meat or fish, } \\
\text { mixed or blended foods, stews, } \\
\text { bread or other cereal products, } \\
\text { and purées) plus breastmilk. } \\
\text { Number of observed days that } \\
\text { food was consumed was divided } \\
\text { by number of observation days. } \\
\text { Age: } 6-12 \text { mo } \\
\text { Assessment Methods } \\
\text { Maternal report }\end{array}$ & $\begin{array}{l}\text { Body composition; Weight; } \\
\text { Length; HC; MUAC } \\
\text { Age: 1-12mo (monthly) } \\
\text { Assessment Methods } \\
\text { Body composition: Skinfold } \\
\text { thickness: calipers; MUAC, chest, } \\
\text { and calf circumferences } \\
\text { measured } \\
\text { Weight: Seca scale to 10g; } \\
\text { converted to z-score } \\
\text { Length: measuring board to } \\
0.1 \mathrm{~cm} \text {; converted to z-score } \\
\text { HC: measured. }\end{array}$ & $\begin{array}{l}\text { Confounders accounted for: } \\
\text { Education: } X \\
\text { SES: } X \\
\text { Sex: } X \\
\text { Feeding practices: } X \\
\text { Birth size: } X \\
\text { Other: Similar SES; Maternal } \\
\text { education NS } \\
\text { Limitations: } \\
\text { Cannot determine whether groups } \\
\text { were similar at baseline; Cannot } \\
\text { determine if outcome assessors } \\
\text { were blinded; Did not adjust for } \\
\text { potential key confounders (maternal } \\
\text { age, race/ethnicity, gestational age) }\end{array}$ \\
\hline $\begin{array}{l}\text { Kalies, } 2005 \\
\text { Prospective Cohort Study; Germany } \\
\text { Sample Size: } \\
\text { Baseline } N=3,036 \\
\text { Analytic } N=2,337 \\
\text { Attrition = } 23 \% \\
\text { Power Analysis and Sufficient Sample Size: } \\
\text { NR } \\
\text { Sex: } \\
49 \% \text { Female } \\
\text { Race/Ethnicity: } \\
\text { NR } \\
\text { Background Diet: } \\
\text { Feeding mode during time of observation: } \\
24.4 \% \text { EBF first } 0-1 \mathrm{mo}, 16.3 \% \text { BF for } 2-3 \mathrm{mo} \text {, } \\
20.8 \% \text { BF for } 4-5 \mathrm{mo}, 38.6 \% \text { BF > or }=6 \mathrm{mo} .\end{array}$ & $\begin{array}{l}\text { CFB categorized as: self-made, } \\
\text { ready-made, or mixture from both } \\
\text { Age: } 2 y \\
\text { Assessment Methods } \\
\text { Caregiver questionnaire }\end{array}$ & $\begin{array}{l}\text { Weight, weight gain } \\
\text { Age: } 24 \mathrm{mo} \\
\text { Assessment Methods } \\
\text { Height, weight: recorded at } \\
\text { preventive medical check-ups } \\
\text { Risk of elevated weight gain at } \\
24 \mathrm{mo} \text {. }\end{array}$ & $\begin{array}{l}\text { Confounders accounted for: } \\
\text { SES: X } \\
\text { Sex: X } \\
\text { Feeding practices: X } \\
\text { Other: Smoking; maternal BMI; birth } \\
\text { order; study center; All full-term } \\
\text { Limitations: } \\
\text { Cannot determine whether groups } \\
\text { were similar on baseline } \\
\text { characteristics; Cannot determine if } \\
\text { outcome assessors were blinded; } \\
\text { Cannot determine validity/reliability } \\
\text { of outcome assessment (height and } \\
\text { weight non-duplicate at medical } \\
\text { check-ups); Did not account for high } \\
\text { attrition rate (23\%); Did not adjust for } \\
\text { potential key confounders } \\
\text { (education; maternal age; } \\
\text { race/ethnicity) }\end{array}$ \\
\hline
\end{tabular}




\begin{tabular}{|c|c|c|c|}
\hline & & & $\begin{array}{l}\text { Parent self-reported feeding data; } \\
\text { primary objective of study was not } \\
\text { timing/type of CFB as such it } \\
\text { appears IV/Exposure was used as a } \\
\text { confounding in models. }\end{array}$ \\
\hline $\begin{array}{l}\text { Kramer, } 2004 \\
\text { Prospective Cohort Study; Belarus } \\
\text { Sample Size: } \\
\text { Baseline N: } 17,601 \\
\text { Analytic N: } 17,046 \\
\text { Attrition: } 3 \% \\
\text { Power Analysis and Sufficient Sample Size: } \\
\text { NR } \\
\text { Sex: } \\
\text { NR } \\
\text { Race/Ethnicity: } \\
\text { NR } \\
\text { Background Diet: } \\
\text { NR; } 100 \% \text { were BF at birth }\end{array}$ & $\begin{array}{l}\text { Age of CFB introduction: based } \\
\text { on intake at the start of the } \\
\text { respective growth interval } \\
\text { CFB: cereals, other solids, and } \\
\text { juices } \\
\text { Age: } 0-12 \text { mo } \\
\text { Assessment Methods: } \\
\text { Maternal interview }\end{array}$ & $\begin{array}{l}\text { Body composition; Weight; } \\
\text { Length; HC } \\
\text { Age: 1-3mo; 3-6mo; 6-9mo; 9- } \\
12 \mathrm{mo} \\
\text { Assessment Methods: } \\
\text { Body composition: WLZ based on } \\
\text { CDC/WHO, } 2000 \\
\text { Weight: NR; used to calculate } \\
\text { WAZ } \\
\text { Length: NR; used to calculate } \\
\text { LAZ } \\
\text { HC: NR }\end{array}$ & $\begin{array}{l}\text { Confounders accounted for: } \\
\text { Education: X } \\
\text { Birth size: X (All with birth weight } \\
\text { >2.5kg) } \\
\text { Gestational age: All full-term } \\
\text { Other: Anthropometric outcome at } \\
\text { current time (WAZ, LAZ, WLZ, HC), } \\
\text { geographic region, urbanicity, } \\
\text { hospital } \\
\text { Limitations: } \\
\text { Cannot determine whether groups } \\
\text { were similar on baseline } \\
\text { characteristics; Cannot determine } \\
\text { whether outcome assessors were } \\
\text { blinded; Cannot determine } \\
\text { validity/reliability of outcome } \\
\text { assessment (unstandardardized); } \\
\text { Did not adjust for potential key } \\
\text { confounders (SES, sex, maternal } \\
\text { age, race/ethnicity though } \\
\text { participants were from RCT) } \\
\text { Cereals consumed may not be } \\
\text { generalizable; Only } 1.2 \% \text { of infants } \\
\text { were consuming cereals at 3mo; } \\
\text { Cannot rule out reverse causality, }\end{array}$ \\
\hline
\end{tabular}




\begin{tabular}{|c|c|c|c|}
\hline & & & $\begin{array}{l}\text { residual confounding, and selection } \\
\text { bias; Trial promoted breast-feeding; } \\
\text { Outcome assessment was } \\
\text { unstandardized (various methods } \\
\text { used; not primary outcome of original } \\
\text { RCT) }\end{array}$ \\
\hline $\begin{array}{l}\text { Krebs, } 2006 \\
\text { Randomized Controlled Trial; United States } \\
\text { Sample Size: } \\
\text { Baseline N: } 88 \\
\text { Analytic N: } 72 \\
\text { Attrition: } 18.2 \% \\
\text { Sample Size Calculation: N=100 to detect } \\
\text { differences of } 0.85 \text { or more in weight-for- } \\
\text { length z scores } \\
\text { Sex: } \\
51.1 \% \text { Female } \\
\text { Race/Ethnicity: } \\
\text { NR } \\
\text { Background Diet: } \\
\text { All infants were EBF and receiving no routine } \\
\text { vitamin or mineral supplements at enrollment } \\
\text { Formula use was minimal before } 7 \mathrm{mo} \text {; by } 9 \\
\text { and } 12 \text { mo (14 infants in each group) were } \\
\text { consuming formula, averaging } 8 \text { to } 9 \text { oz/d }\end{array}$ & $\begin{array}{l}\text { Meat: Received pureed beef } \\
\text { (Gerber Beef and Beef Gravy, } \\
\text { Second Foods) from 5-7mo } \\
\text { Cereal: Received Fe-fortified } \\
\text { cereal from 5-7mo (Gerber Fe } \\
\text { fortified infant rice cereal, without } \\
\text { Zn, First Foods), mixed with either } \\
\text { expressed human milk or water } \\
\text { on approximately a 1:2 ratio of } \\
\text { cereal to fluid } \\
\text { Both groups were encouraged to } \\
\text { wait until } 5 \text { mo to introduce the } \\
\text { CFB, remained on their assigned } \\
\text { food (with fruits and vegetables } \\
\text { as desired after } 1 \text { mo, avoiding the } \\
\text { alternate study food) until } 7 \text { mo, } \\
\text { when they could liberalize their } \\
\text { diet to all foods } \\
\text { Age:5-7mo } \\
\text { Assessment Methods } \\
\text { Diet record, 3d }\end{array}$ & $\begin{array}{l}\text { Body composition; Weight; } \\
\text { Length; HC } \\
\text { Age: Baseline, 4-7mo; 7-12mo; 4- } \\
12 \text { mo for WAZ and LAZ } \\
\text { Assessment Methods } \\
\text { Body composition: WLZ from } \\
\text { measured weight/length } \\
\text { Weight: gain and WAZ; electronic } \\
\text { scale to 1g } \\
\text { Length: gain and LAZ; infant } \\
\text { stadiometer to 0.1cm } \\
\text { HC: laminated tape } \\
\text { WAZ, LAZ, WLZ reported but } \\
\text { data not shown_ }\end{array}$ & $\begin{array}{l}\text { Confounders accounted for: } \\
\text { Sex: } X \\
\text { Birth size: X } \\
\text { Gestational age: X } \\
\text { Limitations: } \\
\text { Cannot determine whether group } \\
\text { allocation was concealed; } \\
\text { Participants were not blind; Cannot } \\
\text { determine whether investigators and } \\
\text { outcome assessors were blinded; } \\
\text { Duration/length of follow-up differed } \\
\text { because subjects started the } \\
\text { intervention at different time points } \\
\text { (e.g., only } 22 \text { infants (7 meat, } 15 \\
\text { cereal) had started CFB at the } 5 \text { mo } \\
\text { visit) } \\
\text { *Intake of protein and Zn at } 7 \text { mo } \\
\text { significantly predicted HC growth } \\
\text { from 7-12mo in univaiate analyses }\end{array}$ \\
\hline $\begin{array}{l}\text { Krebs, } 2013 \\
\text { Randomized Controlled Trial; United States } \\
\text { Sample Size: } \\
\text { Baseline N: } 45 \\
\text { Analytic N: } 41 \\
\text { Attrition: } 8.9 \% \\
\text { Sample Size Calculation: } \mathrm{N}=15 \text { per group to } \\
\text { detect a } 0.20 \mathrm{mg} \text { difference in total absorbed } \\
\mathrm{Zn}\end{array}$ & $\begin{array}{l}\text { Meat: Received one jar }(71 \mathrm{~g}) \\
\text { pureed meat and gravy per } \mathrm{d} \text { by } \\
7 \mathrm{mo} \text { and }>1 \text { to } \leq 2 \text { jars/d by } 9 \mathrm{mo} \\
\text { Fe-Zn Fortified Cereal: Received } \\
\text { Fe and } \mathrm{Zn} \text { fortified cereal, offer } 1 \\
\text { serving/d (15g dry weight } \\
\text { according to the manufacturer's } \\
\text { label) by } 7 \mathrm{mo} \text { and } 2 \text { servings/d by } \\
9 \mathrm{mo} \\
\text { Fe-Fortified Cereal: Received Fe- } \\
\text { fortified cereal, offer } 1 \text { serving/d }\end{array}$ & $\begin{array}{l}\text { Weight; Length } \\
\text { Age: } 7,8,9 \mathrm{mo} \\
\text { Assessment Methods } \\
\text { Weight: naked; electronic digital } \\
\text { balance to } 1 \mathrm{~g} \text { in duplicate_ } \\
\text { Length: infant stadiometer to } \\
0.1 \mathrm{~cm} \text { in duplicate }\end{array}$ & $\begin{array}{l}\text { Confounders accounted for: } \\
\text { Limitations: } \\
\text { Cannot determine whether group } \\
\text { allocation was concealed; } \\
\text { Participants were not blinded; } \\
\text { Cannot determine if investigators or } \\
\text { outcome assessors were blinded; } \\
\text { Infants were allowed ad lib feeding } \\
\text { for foods other than those assigned }\end{array}$ \\
\hline
\end{tabular}




\begin{tabular}{|c|c|c|c|}
\hline $\begin{array}{l}\text { Sex: } \\
\text { NR } \\
\text { Race/Ethnicity: } \\
\text { NR } \\
\text { Background Diet: } \\
\text { EBF: } 100 \%, \text { all infants }\end{array}$ & $\begin{array}{l}\text { (15g dry weight according to the } \\
\text { manufacturer's label) by } 7 \text { mo and } \\
2 \text { servings/d by } 9 \text { mo } \\
\text { Fruits, vegetables, teething } \\
\text { biscuits, and unfortified cereals } \\
\text { and other finger foods were } \\
\text { allowed ad lib. Cereal groups } \\
\text { were instructed to avoid single- } \\
\text { ingredient meats; at } 8 \text { mo, } \\
\text { commercial infant dinners were } \\
\text { allowed. Meat group instructed to } \\
\text { avoid fortified infant cereals but } \\
\text { was allowed to use unfortified } \\
\text { cereals such as quick oats or } \\
\text { commercial unfortified cooked } \\
\text { rice starting at } 7 \text { mo ( } \leq 15 \mathrm{~g} / \mathrm{d}) \text {. } \\
\text { Age: } 6-9 \mathrm{mo} \\
\text { Assessment Methods } \\
\text { Food record, } 3 \mathrm{~d}\end{array}$ & & $\begin{array}{l}\text { (e.g., fruits and vegetables), and } \\
\text { dietary intake was not accounted for } \\
\text { Multiple comparisons not adjusted } \\
\text { for_ }\end{array}$ \\
\hline $\begin{array}{l}\text { Libuda, } 2015 \\
\text { Randomized Controlled Trial; Germany } \\
\text { Sample Size: } \\
\text { Baseline N: } 214 \\
\text { Analytic N: RBC fatty acids: 158; Plasma } \\
\text { fatty acids: } 155 \\
\text { Attrition: RBC fatty acids: } 26.2 \% \text {; Plasma } \\
\text { fatty acids: } 27.6 \% \\
\text { Sample Size Calculation: N=63 to detect a } \\
0.33 \% \text { difference in RBC-DHA phospholipids } \\
\text { Sex: } \\
\text { R0\% Female } \\
\text { Race/Ethnicity: } \\
\text { NR } \\
\text { Background Diet: } \\
58 \% \text { BF, } \sim 16 \% \text { mixed feeding, } \sim 26 \% \text { FF }\end{array}$ & $\begin{array}{l}\text { Rapeseed oil (ALA): Received } \\
\text { CFB with ALA-rich rapeseed oil } \\
\text { from 4-10mo } \\
\text { Fish (DHA): Received CFB as } \\
\text { salmon 2/wk to provide preformed } \\
\text { DHA from 4-10mo } \\
\text { Corn oil (Linoleic Acid): Received } \\
\text { CFB with linoleic acid-rich corn oil } \\
\text { from 4-10mo } \\
\text { Study foods were commercial } \\
\text { meals with vegetables, potatoes, } \\
\text { and meat (Rapeseed oil, Corn oil) } \\
\text { or fish (Fish) } \\
\text { Age:4-10mo } \\
\text { Assessment Methods } \\
\text { Diet record, weighed }\end{array}$ & $\begin{array}{l}\text { Weight; Length } \\
\text { Age: 10mo } \\
\text { Assessment Methods } \\
\text { NR_ }\end{array}$ & $\begin{array}{l}\text { Confounders accounted for: } \\
\text { Groups did not differ at baseline on } \\
\text { SES, sex, feeding practices, } \\
\text { maternal age, birth size or } \\
\text { gestational age } \\
\text { Limitations: } \\
\text { Fish group (IG-F) not able to be } \\
\text { blinded; Cannot determine whether } \\
\text { adherence to study protocol was } \\
\text { similar across groups; Cannot } \\
\text { determine whether outcome } \\
\text { assessors were blinded; Cannot } \\
\text { determine validity/reliability of } \\
\text { outcome assessment; Did not } \\
\text { account for high loss to follow-up } \\
\text { (>20\%) }\end{array}$ \\
\hline $\begin{array}{l}\text { Lind, } 2004 \\
\text { Randomized Controlled Trial; Sweden }\end{array}$ & $\begin{array}{l}\text { CC group: commercial MCD and } \\
\text { porridge; MCD was oat and wheat }\end{array}$ & Weight; Length; HC; MUAC & Confounders accounted for: \\
\hline
\end{tabular}




\begin{tabular}{|c|c|c|c|}
\hline $\begin{array}{l}\text { Sample Size: } \\
\text { Baseline } \mathrm{N}: 300 \\
\text { Analytic } \mathrm{N}: 263 \\
\text { Attrition: } 12 \% \\
\text { Sample size calculation: } \mathrm{n}=58-84 \text { per group } \\
\text { at } 80 \% \text { power with } \mathrm{a}=0.05 \text { to detect } \\
\text { differences in length of } 0.9 \mathrm{~cm}, 0.4 \mathrm{~kg} \\
\frac{\text { Sex: }}{\text { NR }} \\
\frac{\text { Race/Ethnicity: }}{\text { NR }} \\
\frac{\text { Background Diet: }}{\text { NR (BF or FF) }}\end{array}$ & $\begin{array}{l}\text { flour, mixed with milk powder and } \\
\text { Fe-fortified } \\
\text { PR group: phytate-reduced MCD } \\
\text { and phytate-reduced porridge; } \\
\text { MCD was replaced with white- } \\
\text { wheat flour } \\
\text { IF group: milk-based infant } \\
\text { formula and porridge } \\
\text { Age: } 6-12 \text { mo } \\
\text { Assessment Methods } \\
\text { NR }\end{array}$ & $\begin{array}{l}\text { Age: } 6,12 \text {, and } 18 \mathrm{mo} \\
\text { Assessment Methods } \\
\text { Weight: measured on Seca scale } \\
\text { in triplicate to } 0.02 \mathrm{~kg} \text {; used to } \\
\text { calculate WAZ } \\
\text { Length: measured on } \\
\text { infantometer in triplicate to } 1 \mathrm{~mm} \text {; } \\
\text { used to calculate LAZ; } \\
\text { HC and MUAC: measured via } \\
\text { non-stretchable tape to } 1 \mathrm{~mm} \\
\text { - }\end{array}$ & $\begin{array}{l}\text { Other: NR } \\
\text { Limitations: } \\
\text { Cannot determine whether groups } \\
\text { differed at baseline on key } \\
\text { characteristics; Cannot determine } \\
\text { adherence to study protocols; } \\
\text { Cannot determine impact of } \\
\text { unintended exposures (partcipants } \\
\text { allowed to consume anything from } \\
\text { 12-18mo) }\end{array}$ \\
\hline $\begin{array}{l}\text { Liu, } 1993 \\
\text { Randomized Controlled Trial; China } \\
\text { Sample Size: } \\
\text { Baseline N: } 226 \\
\text { Analytic N: } 164 \\
\text { Attrition: } 27.4 \% \\
\text { Power Analysis and Sufficient Sample Size: } \\
\text { NR } \\
\text { Sex: } \\
45 \% \text { Female } \\
\text { Race/Ethnicity: } \\
\text { NR } \\
\text { Background Diet: } \\
\text { Most were partially BF }\end{array}$ & $\begin{array}{l}\text { Fortified Rusk: received } 1 \\
\text { biscuit/day for } 3 \text { mo (presumed to } \\
\text { be fortified with iron, zinc, vit. A, } \\
\text { calcium, and folic acid) } \\
\text { Unfortified Rusk: received } 1 \\
\text { unfortified biscuit/day for } 3 \text { mo } \\
\text { CFB: Rusks were biscuits made } \\
\text { from wheat flour, sugar, and } \\
\text { vegetable oil } \\
\text { Age:6-16mo } \\
\text { Assessment Methods } \\
\text { Doctors ensured delivery of } \\
\text { weekly rusk supply; mothers } \\
\text { monitored child intake }\end{array}$ & $\begin{array}{l}\text { Weight; Length } \\
\text { Age: } 9 \text {-16mo } \\
\text { Assessment Methods } \\
\text { Weight: Beam balance } \\
\text { Length: length board_ }\end{array}$ & $\begin{array}{l}\text { Confounders accounted for: } \\
\text { Limitations: } \\
\text { Cannot determine group allocation } \\
\text { sequencing or concealment } \\
\text { methods; Cannot determine whether } \\
\text { investigators, participants, or } \\
\text { outcome assessors were blinded; } \\
\text { Cannot determine validity/reliability } \\
\text { of outcome assessment; Cannot } \\
\text { determine influence of background } \\
\text { or usual diet on growth outcomes; } \\
\text { Didnot adjust analyses for sex, which } \\
\text { was unbalanced across groups } \\
\text { Limited generalizability due to } \\
\text { sample from rural villages with high- } \\
\text { rates of malnutrition }\end{array}$ \\
\hline
\end{tabular}




\begin{tabular}{|c|c|c|c|}
\hline $\begin{array}{l}\text { Lonnerdal, } 1990 \\
\text { Randomized Controlled Trial; China } \\
\text { Sample Size: } \\
\text { Baseline N: NR } \\
\text { Analytic N: NR } \\
\text { Attrition: CD } \\
\text { Power Analysis and Sufficient Sample Size: } \\
\text { NR } \\
\text { Sex: } \\
\text { RR } \\
\text { Race/Ethnicity: } \\
\text { Background Diet: } \\
100 \% \text { FF }\end{array}$ & $\begin{array}{l}\text { Group A: Fed formula A w/o } \\
\text { cereal; continued exclusive use of } \\
\text { formula from 4-7mo } \\
\text { Group D: Fed formula A with } \\
25 \mathrm{~g} / \mathrm{d} \text { cereal from } 4-7 \mathrm{mo} \\
\text { Other groups confounded by } \\
\text { formula: } \\
\text { Formula B+ Cereal: Fed formula } \\
\text { B and } 25 \mathrm{~g} / \mathrm{d} \text { cereal from } 4-7 \mathrm{mo} \\
\text { Formula C+ Cereal: Fed formula } \\
\text { C and } 25 \mathrm{~g} / \mathrm{d} \text { cereal from } 4-7 \mathrm{mo} \\
\text { Age: } 4-7 \mathrm{mo} \\
\text { Assessment Methods } \\
\text { Trained nurses assisted mothers } \\
\text { in weighing a/o recording intake } \\
\text { of infant at home visits }\end{array}$ & $\begin{array}{l}\text { Body composition; Weight; } \\
\text { Length; HC } \\
\text { Age: } 4,5,6 \text {, and } 7 \text { mo } \\
\text { Assessment Methods } \\
\text { Weight, length, and HC measured } \\
\text { at clinic } \\
\text { Weight-for-height: calculated from } \\
\text { measures } \\
\text { Skinfold thickness: NR_ }\end{array}$ & $\begin{array}{l}\text { Confounders accounted for: } \\
\text { Other: NR } \\
\text { Limitations: } \\
\text { Cannot determine group allocation or } \\
\text { randomization methods; Cannot } \\
\text { determine whether groups were } \\
\text { similar on baseline characteristics; } \\
\text { Cannot determine validity/reliability } \\
\text { of outcome assessment; Cannot } \\
\text { determine attrition because sample } \\
\text { size was not reported; Did not adjust } \\
\text { for other sources of bias; Adequacy } \\
\text { of statistical methods insufficient } \\
\text { Lack of reporting on sample size, } \\
\text { characteristics, IV/Exposure } \\
\text { assessment_ }\end{array}$ \\
\hline $\begin{array}{l}\text { Makrides, } 1998 \\
\text { Randomized Controlled Trial; Australia } \\
\text { Sample Size: } \\
\text { Baseline N High-Fe Group: } 40 \\
\text { Baseline N Control Group: } 39 \\
\text { Analytic N High-Fe Group: } 36 \\
\text { Analytic N Control Group: } 26 \\
\text { Attrition: } 22 \% \\
\text { Sample Size Calculation: } \mathrm{N}=60 \text { to detect } \\
\text { differences of } 6 \mathrm{~g} / \mathrm{L} \text { in } \mathrm{Hb} \text { and } 18 \mathrm{mg} / \mathrm{L} \text { in SF } \\
\text { Sex: } \\
50 \% \text { Female } \\
\text { Race/Ethnicity: } \\
\text { NR } \\
\text { Background Diet: } \\
\text { EBF: } 100 \% \text { at } 6 \mathrm{mo} ; \mathrm{BF}: 100 \% \text { through } 9 \mathrm{mo}\end{array}$ & $\begin{array}{l}\text { High-Fe weaning diet: Offered } \\
\text { four } 30-40 \mathrm{~g} \text { servings/wk of red } \\
\text { meat and four } 113 \mathrm{~g} \text { jars/wk of Fe- } \\
\text { fortified cereal } \\
\text { Control: Standard nutritional } \\
\text { advice (including advice to } \\
\text { consume iron-fortified infant } \\
\text { cereal from } 4 \text { to } 6 \mathrm{mo} \text { ) } \\
\text { Age: } 6-12 \mathrm{mo} \\
\text { Assessment Methods } \\
\text { FFQ (for iron-containing foods) }\end{array}$ & $\begin{array}{l}\text { Weight; Length; HC } \\
\text { Age: } 9 \mathrm{mo}, 12 \mathrm{mo} \\
\text { Assessment Methods } \\
\text { Weight: Measured by study } \\
\text { personnel } \\
\text { Length: Measured by study } \\
\text { personnel, supine to nearest } \\
0.5 \mathrm{~cm} \\
\text { HC: Measured by study } \\
\text { personnel, to nearest } 0.1 \mathrm{~cm}\end{array}$ & $\begin{array}{l}\text { Confounders accounted for: } \\
\text { Feeding practices: X (All EBF) } \\
\text { Birth size: X (All >2500g) } \\
\text { Gestational age: X (All >37wk) } \\
\text { Limitations: } \\
\text { Cannot determine if group allocation } \\
\text { was concealed; Participants were } \\
\text { not blinded; cannot determine if } \\
\text { outcome assessors or investigators } \\
\text { were blinded; Cannot determine the } \\
\text { validity/reliability of outcome } \\
\text { assessment (i.e., single vs multiple } \\
\text { growth measures); Statistical } \\
\text { analyses not described and data not } \\
\text { shown }\end{array}$ \\
\hline
\end{tabular}




\begin{tabular}{|c|c|c|c|}
\hline $\begin{array}{l}\text { Makrides, } 2002 \\
\text { Randomized Controlled Trial; Australia } \\
\text { Sample Size: } \\
\text { Control Baseline N: } 28 \text { (BF), } 27 \text { (FF) } \\
\text { Regular Egg Baseline N: } 27 \text { (BF), } 26 \text { (FF) } \\
\text { N-3 Egg Baseline N: } 27 \text { (BF(, } 26 \text { (FF) } \\
\text { Control Analytic N: } 23 \text { (BF), } 23 \text { (FF) } \\
\text { Regular Egg Analytic N: } 23 \text { (BF), } 24 \text { (FF) } \\
\text { N-3 Egg Analytic N: } 24 \text { (BF, } 20 \text { (FF) } \\
\text { Attrition: 15\% } \\
\text { Power Analysis/Sufficient Sample Size: } \\
\text { N=40 per egg group, N=20 in control to } \\
\text { detect differences in iron status outcomes } \\
\text { (8g/L (SD=10) in Hb and 20g/L (SD=25) in } \\
\text { SF). } \\
\text { Sex: } \\
\text { 53\% Female } \\
\text { Race/Ethnicity: } \\
\text { NR } \\
\text { Background Diet: } \\
\text { BF: 51\% }\end{array}$ & $\begin{array}{l}\text { Regular egg group: Provided } 4 \\
\text { eggs/wk from } 6 \text { to } 12 \mathrm{mo} \\
\mathrm{N}-3 \text { egg group: Provided } 4 \text { DHA } \\
\text { enriched eggs/wk from } 6 \text { to } 12 \mathrm{mo} \\
\text { Control group: Followed standard } \\
\text { weaning diet of choice from } 6 \text { to } \\
12 \mathrm{mo} \\
\text { Age: } 6-12 \mathrm{mo} \\
\text { Assessment Methods } \\
\text { Maternal questionnaire }\end{array}$ & $\begin{array}{l}\text { Weight; Length; HC } \\
\text { Age:12mo } \\
\text { Assessment Methods } \\
\text { Weight: NR } \\
\text { Length: NR } \\
\text { HC: NR_. }\end{array}$ & $\begin{array}{l}\text { Confounders accounted for: } \\
\text { Feeding practices: } X \\
\text { Birth size: } X(\text { All }>2500 \mathrm{~g}) \\
\text { Gestational age: } X(\text { All }>37 \mathrm{wk}) \\
\text { Limitations: } \\
\text { Cannot determine validity/reliability } \\
\text { of outcome assessment (methods } \\
\text { were not described) }\end{array}$ \\
\hline $\begin{array}{l}\text { Morgan, } 2004 \\
\text { Prospective Cohort Study; United Kingdom } \\
\text { Sample Size: } \\
\text { Baseline N: } 144 \\
\text { Analytic N: } 144 \\
\text { Attrition: } 0 \% \\
\text { Power Analysis: NR } \\
\text { Sex: } \\
47 \% \text { Female } \\
\text { Race/Ethnicity: } \\
97 \% \text { White } \\
\text { Background Diet: } \\
\text { Ever BF: } 83 \% ; \text { BF at } 4 \mathrm{mo:} 37 \% \text {; BF at } 6 \mathrm{mo:} \\
2 \%\end{array}$ & $\begin{array}{l}\text { Meat intake: Total grams of red } \\
\text { (beef, pork and lamb) and white } \\
\text { (chicken, turkey, fish) meat } \\
\text { consumed from 4-12mo and from } \\
\text { 4-16mo } \\
\text { Median for all infants }>20 \mathrm{mo}: \\
278 \mathrm{~g} / \mathrm{d}(178-425 \mathrm{~g} / \mathrm{d}) \\
\text { Age: } 4-12 \mathrm{mo}, 4-16 \mathrm{mo}, 4-24 \mathrm{mo} \\
\text { Assessment Methods } \\
\text { Food record, } 7 \mathrm{~d}, \text { weighed }\end{array}$ & $\begin{array}{l}\text { Weight; Length; HC } \\
\text { Age: } 4,8,12,16,20 \text { and } 24 \mathrm{mo} \\
\text { Assessment Methods } \\
\text { Weight: Measured in duplicate or } \\
\text { triplicate by study personnel, to } \\
\text { nearest } 10 \mathrm{~g} \\
\text { Length: Measured in duplicate or } \\
\text { triplicate by study personnel, } \\
\text { supine to nearest } 1 \mathrm{~mm} \\
\text { HC: Measured in duplicate or } \\
\text { triplicate by study personnel_ }\end{array}$ & $\begin{array}{l}\text { Confounders accounted for: } \\
\text { Feeding practices: } X \\
\text { Birth size: } X \\
\text { Other: Energy intake, protein intake } \\
\text { Limitations: } \\
\text { Cannot determine whether groups } \\
\text { were similar at baseline on key } \\
\text { characteristics; Cannot determine if } \\
\text { outcome assessors were blinded; } \\
\text { Did not adjust for potential key } \\
\text { confounders (education, SES, sex, } \\
\text { maternal age, race/ethnicity or } \\
\text { gestational age) }\end{array}$ \\
\hline
\end{tabular}




\begin{tabular}{|c|c|c|c|}
\hline $\begin{array}{l}\text { Olaya, } 2013 \\
\text { Randomized Controlled Trial; Colombia } \\
\text { Sample Size: } \\
\text { Baseline N: } 85 \\
\text { Analytic N: } 76 \\
\text { Attrition: } 11 \% \\
\text { Sample Size Calculation: N=64 per group to } \\
\text { detect a } 0.5 S D \text { difference in outcomes } \\
\text { Sex: } \\
50 \% \text { Female } \\
\text { Race/Ethnicity: } \\
\text { NR } \\
\text { Background Diet: } \\
\text { EBF: } 100 \% \text { at } 4 \text { mo; At } 6 \text { mo: } 8 \%>11 \text { bottle- } \\
\text { feed/d, } 7 \% \text { consuming cow's milk } \\
\text { Age of introduction to CFB: } 45 \% \text { between } 4- \\
6 \text { mo; } 30 \% \text { consumed red meat at } 6 \text { mo }\end{array}$ & $\begin{array}{l}\text { Intervention group: Received } \\
\text { individual, face-to-face nutrition } \\
\text { counseling with } 3 \text { key messages: } \\
\text { the importance of continuing BF } \\
\text { alongside CF, red meat as a } \\
\text { source of Fe to prevent anemia } \\
\text { ( } 5 \text { portions/wk, red meat, } \\
\text { chicken liver and heart), and daily } \\
\text { fruit and vegetables as part of a } \\
\text { healthy diet } \\
\text { Control group: Received standard } \\
\text { complementary feeding advice } \\
\text { from health care professionals } \\
\text { (including meat consumption, but } \\
\text { no advice on frequency or } \\
\text { amount of foods was given) } \\
\text { CFB: At } 12 \text { mo, the Intervention } \\
\text { group consumed more meat, red } \\
\text { meat, fruit, vegetables, and } \\
\text { legumes, while the Control group } \\
\text { was more likely to consume } \\
\text { follow-on formula, milk, cow milk, } \\
\text { and sweetened foods (sugar, } \\
\text { jelly, chocolate, sweets) } \\
\text { Age: } 6-12 \text { mo } \\
\text { Assessment Methods: FFQ }\end{array}$ & $\begin{array}{l}\text { Weight; Length; HC; MUAC } \\
\text { Age: } 12 \mathrm{mo} \\
\text { Assessment Methods } \\
\text { Weight: Measured by study } \\
\text { personnel; } z \text { scores determined } \\
\text { using WHO, } 2007 \text { standards } \\
\text { Length: Measured in triplicate by } \\
\text { study personnel, recumbent to } \\
\text { nearest } 1 \mathrm{~mm} ; \mathrm{z} \text { scores } \\
\text { determined using WHO, } 2007 \\
\text { standards } \\
\text { MUAC: Measured by study } \\
\text { personnel to nearest } 1 \mathrm{~mm} \\
\text { HC: Measured by study personnel } \\
\text { to nearest } 1 \mathrm{~mm} \text {. }\end{array}$ & $\begin{array}{l}\text { Confounders accounted for: } \\
\text { SES: } X \\
\text { Sex: } X \\
\text { Other: Baseline growth measures } \\
\text { Limitations: } \\
\text { Groups differed at baseline on key } \\
\text { characteristics and differences were } \\
\text { not adjusted for in analyses (father's } \\
\text { age, baseline weight, baseline } \\
\text { MUAC); Despite intervention, control } \\
\text { and intervention groups consumed } \\
\text { similar CFB; Participants were not } \\
\text { blinded; cannot determine if outcome } \\
\text { assessors or investigators were } \\
\text { blinded }\end{array}$ \\
\hline $\begin{array}{l}\text { Robinson, } 2009 \\
\text { Prospective Cohort Study; United Kingdom } \\
\text { Sample Size: } \\
\text { Baseline N: } 1195 \\
\text { Analytic N: } 536 \\
\text { Attrition: } 55 \% \\
\text { Power Analysis and Sufficient Sample Size: } \\
\text { NR } \\
\text { Sex: } \\
\text { 47\% Female } \\
\text { Race/Ethnicity: } \\
\text { NR }\end{array}$ & $\begin{array}{l}\text { One dietary pattern was identified } \\
\text { at } 12 \text { mo using principal } \\
\text { component analysis, and each } \\
\text { infant received a score for } \\
\text { adherence to the pattern: } \\
\text { Infant guidelines pattern: High } \\
\text { consumption of fruit, vegetables, } \\
\text { cooked meat and fish, and other } \\
\text { home-prepared foods (rice, } \\
\text { pasta), and low consumption of } \\
\text { commercial baby foods }\end{array}$ & $\begin{array}{l}\text { Body composition } \\
\text { Age: } 4 y \\
\text { Assessment Methods } \\
\text { Body composition: } \\
\text { - } \quad \text { BMI: Calculated using } \\
\text { measured height, weight } \\
\text { - Lean mass (LM): Whole- } \\
\text { body DXA } \\
\text { - LM index: lean mass } \\
\text { divided by height2 } \\
\text { - Fat mass (FM): Whole-body } \\
\text { DXA }\end{array}$ & $\begin{array}{l}\text { Confounders accounted for: } \\
\text { SES: } X \\
\text { Maternal age: } X \\
\text { Feeding practices: } X \\
\text { Birth size: } X \\
\text { Other: Maternal BMI, maternal } \\
\text { height, smoking in late pregnancy } \\
\text { Limitations: } \\
\text { Cannot determine whether groups } \\
\text { were similar at baseline on key } \\
\text { characteristics; Cannot determine } \\
\text { whether outcome assessors were }\end{array}$ \\
\hline
\end{tabular}




\begin{tabular}{|c|c|c|c|}
\hline $\begin{array}{l}\text { Background Diet: } \\
\text { Never BF: } 12.5 \% ; B F \text { for } 6 \mathrm{mo}: 20 \% \\
\text { Age of introduction to CFB: } 76 \% \text { by } 4 \mathrm{mo}\end{array}$ & $\begin{array}{l}\text { Age: } 6 \text { and } 12 \text { mo Assessment } \\
\text { Methods } \\
\text { FFQ; maternal interview }\end{array}$ & $\begin{array}{l}\text { - FM index: FM divided by } \\
\text { height 2. }\end{array}$ & $\begin{array}{l}\text { blinded; Cannot determine the } \\
\text { validity/reliability of some outcome } \\
\text { measures (i.e., single vs multiple } \\
\text { height, weight measures); Did not } \\
\text { define age of introduction of CFB } \\
\text { variable; Did not account for high } \\
\text { loss to follow-up (55\%); Did not } \\
\text { adjust for potential key confounders } \\
\text { (education, sex, race/ethnicity, } \\
\text { gestational age) }\end{array}$ \\
\hline $\begin{array}{l}\text { Rose, } 2016 \\
\text { Prospective Cohort Study; United States } \\
\text { Sample Size: } \\
\text { Baseline N: } 1807 \\
\text { Analytic N: } 1029 \\
\text { Attrition: } 43 \% \\
\text { Power Analysis and Sufficient Sample Size: } \\
\text { NR } \\
\text { Sex: } \\
\text { 51\% Female } \\
\text { Race/Ethnicity: } \\
90 \% \text { White } \\
\text { Background Diet: } \\
\text { BF at 9mo: } ~ 34 \% \\
\text { Age of introduction to CFB: } \sim 5 \mathrm{mo}\end{array}$ & $\begin{array}{l}\text { Five dietary patterns were } \\
\text { identified at 9mo using latent } \\
\text { class analysis, and each infant } \\
\text { was assigned to the pattern they } \\
\text { scored highest on: } \\
\text { 1. BFFV: Breastfed Fruits and } \\
\text { Vegetables: Breastmilk, } \\
\text { fruits, and vegetables, and } \\
\text { low intake of energy-dense } \\
\text { foods } \\
\text { 2. BFLV: Breastfed Low } \\
\text { Variety: Breastmilk, and low } \\
\text { intake of fruits and } \\
\text { vegetables, low diet variety } \\
\text { 3. FFFV: Formula-Fed Fruits } \\
\text { and Vegetables: Formula, } \\
\text { fruits, and vegetables, and } \\
\text { low intake of energy-dense } \\
\text { foods } \\
\text { 4. FFLV: Formula-Fed Low } \\
\text { Variety: Formula, and low } \\
\text { intake of fruits and } \\
\text { vegetables, low diet variety } \\
\text { MXHED: Mixed High } \\
\text { Energy Density: Breastmilk } \\
\text { and formula, low intake of } \\
\text { fruits and vegetables, diet } \\
\text { variety, and higher intake of } \\
\text { energy-density foods (e.g. }\end{array}$ & $\begin{array}{l}\text { Weight status; Body composition; } \\
\text { Weight } \\
\text { Age: } 1 y \\
\text { Assessment Methods } \\
\text { Weight status: prevlance of } \\
\text { overweight classified as } \geq 85 \text { th } \\
\text { WFL percentile; WFL calculated } \\
\text { using maternal-reported weight } \\
\text { and length } \\
\text { Body composition: WLZ } \\
\text { Weight: WAZ; maternal-report }\end{array}$ & $\begin{array}{l}\text { Confounders accounted for: } \\
\text { Education: } X \\
\text { SES: } X \\
\text { Sex: } X \\
\text { Maternal age: } X \\
\text { Race/ethnicity: } X \\
\text { Feeding practices: } X \\
\text { Birth size: } X \\
\text { Gestational age: } X \\
\text { Other: Childcare, parity, } \\
\text { prepregnancy BMI, marital status, } \\
\text { postpartum depression, excessive } \\
\text { gestational weight gain } \\
\text { Limitations: } \\
\text { Outcome assessors were not blinded } \\
\text { (maternal report); Did not use } \\
\text { valid/reliable methods to measure } \\
\text { outcomes (weight was self-reported } \\
\text { by mothers); Did not account for high } \\
\text { loss to follow-up (43\%)'; Did not } \\
\text { describe p-values for all analyses } \\
\text { reported }\end{array}$ \\
\hline
\end{tabular}




\begin{tabular}{|c|c|c|c|}
\hline & $\begin{array}{l}\quad \text { French fries, sweet foods) } \\
\text { Age:9mo } \\
\text { Assessment Methods FFQ }\end{array}$ & & \\
\hline $\begin{array}{l}\text { Santorelli, } 2014 \\
\text { Prospective Cohort Study; United Kingdom } \\
\text { Sample Size: } \\
\text { Baseline N: } 1735 \\
\text { Analytic N: } 1327 \\
\text { Attrition: } 24 \% \\
\text { Power Analysis and Sufficient Sample Size: } \\
\text { NR } \\
\text { Sex: } \\
\text { NR } \\
\text { Race/Ethnicity: } \\
38 \% \text { White, } 49 \% \text { Pakistani, } 7 \% \text { South Asian, } \\
6 \% \text { Other } \\
\text { Background Diet: } \\
\text { BF after CFB introduction: } 32 \% \\
\text { Age of CFB introduction: } 10 \%<17 \mathrm{wk}\end{array}$ & $\begin{array}{l}\text { Age of non-sweetened solid foods } \\
\text { (e.g. baby rice, pureed } \\
\text { vegetables, fruits or rice, and } \\
\text { lentils/dhal); sweetened foods } \\
\text { (e.g. egg custard, rice pudding, } \\
\text { sweetened rusks, biscuits and } \\
\text { cake) were introduced as a first } \\
\text { food: whether sweetened foods } \\
\text { were introduced as a first food } \\
\text { (including sweetened and } \\
\text { nonsweetened foods given } \\
\text { together); } \\
\text { Sweetened drinks (e.g. cola, } \\
\text { squash, lemonade, sweetened } \\
\text { tea and pre-prepared 'baby' } \\
\text { drinks) given at <17wk of age } \\
\text { Age: } 6,12 \text { mo } \\
\text { Assessment Methods } \\
\text { Maternal questionnaire }\end{array}$ & $\begin{array}{l}\text { Body composition } \\
\text { Age: } 3 y \\
\text { Assessment Methods } \\
\text { Body composition: BMIZ, } \\
\text { calculated via measured height, } \\
\text { weight and converted into age-- } \\
\text { and sex-adjusted z-scores based } \\
\text { on WHO, } 2006 \text { growth standards. }\end{array}$ & $\begin{array}{l}\text { Confounders accounted for: } \\
\text { Education: } X \\
\text { Sex: } X \\
\text { Maternal age: } X \\
\text { Race/ethnicity: } X \\
\text { Feeding practices: X } \\
\text { Birth size: } X \\
\text { Gestational age: } X \\
\text { Other: Marital status, smoking during } \\
\text { pregnancy, maternal BMI, delivery } \\
\text { mode } \\
\text { Limitations: } \\
\text { Cannot determine whether groups } \\
\text { were similar at baseline on key } \\
\text { characteristics; Cannot determine } \\
\text { whether outcome assessors were } \\
\text { blinded; Cannot determine the } \\
\text { validity/reliability of outcome } \\
\text { measures (i.e., single vs multiple } \\
\text { growth measures); Did not account } \\
\text { for high loss to follow-up (24\%); Did } \\
\text { not adjust for potential key } \\
\text { confounders (SES) }\end{array}$ \\
\hline
\end{tabular}




\begin{tabular}{|c|c|c|c|}
\hline $\begin{array}{l}\text { Schack-Nielsen, } 2010 \\
\text { Prospective Cohort Study; Denmark } \\
\text { Sample Size: } \\
\text { Baseline N: } 8129 \\
\text { Analytic N: } 5068 \\
\text { Attrition: } 39 \% \\
\text { Power Analysis/Sample Size Calculation: NR } \\
\text { Sex: } \\
\text { NR } \\
\text { Race/Ethnicity: } \\
\text { NR } \\
\text { Background Diet: } \\
\text { BF duration: } 3.5 \mathrm{mo} ; \text { BF <2wk: } 18 \% \\
\text { Age of CFB introduction: } 3.8 \mathrm{mo} \\
79 \% \text { introduced to vegetables and spoon- } \\
\text { feeding at the same age; } 19 \% \text { started spoon- } \\
\text { feeding/gruel first }\end{array}$ & $\begin{array}{l}\text { Age of introduction to CFB: } \\
\text { Continuous, mo; Categorical, } \\
\geq 4 \mathrm{mo} \text { vs <4mo; Number of food } \\
\text { items at } 3,4,5 \text {, and } 6 \mathrm{mo} \\
\text { CFB: spoon-feeding (i.e., gruel), } \\
\text { vegetables, eggs, meat, firm food } \\
\text { Age: } 1 \mathrm{y} \\
\text { Assessment Methods: } \\
\text { Maternal questionnaire }\end{array}$ & $\begin{array}{l}\text { Weight status; Body composition; } \\
\text { WC } \\
\text { Age: } 1-42 y \\
\text { Assessment Methods: } \\
\text { Weight status: risk of overweight } \\
\text { based on BMI } \geq 25 \text { using self- } \\
\text { reported height and weight at } 42 y \\
\text { Body composition: BMI calculated } \\
\text { using height, weight measured by } \\
\text { study personnel at } 1,3 \text {, and } 6 y \text {; } \\
\text { school records at } 7-14 y \text {; self- } \\
\text { reported at 2-34y, } 42 y \\
\text { WC: Self-reported at } 42 y \text { via } \\
\text { mailed questionnaire and tape } \\
\text { measure }\end{array}$ & $\begin{array}{l}\text { Confounders accounted for: } \\
\text { Education: } X \\
\text { SES: } X \\
\text { Sex: } X \\
\text { Maternal age: X } \\
\text { Feeding practices: X } \\
\text { Birth size: X (Birth weight) } \\
\text { Gestational age: } X \\
\text { Other: Prepregnancy BMI, } \\
\text { gestational weight gain, smoking } \\
\text { during pregnancy, marital status, } \\
\text { weight at 1y } \\
\text { Limitations: } \\
\text { Cannot determine whether groups } \\
\text { were similar at baseline on key } \\
\text { characteristics; Outcome assessors } \\
\text { were not blinded at 20-34y, 42y; Did } \\
\text { not use valid/reliable measures to } \\
\text { assess outcomes (weight was self- } \\
\text { reported at 20-34y and 42y); Did not } \\
\text { account for high loss to follow-up } \\
\text { (39\%); Did not adjust for potential } \\
\text { key confounders (race/ethnicity); Not } \\
\text { all variables were analyzed in } \\
\text { relation to all outcomes, and data } \\
\text { from figures not adequately } \\
\text { described } \\
\text { Limited generalizability due to CFB } \\
\text { practices at the time of original data } \\
\text { collection (1959-1960) }\end{array}$ \\
\hline
\end{tabular}




\begin{tabular}{|c|c|c|c|}
\hline $\begin{array}{l}\text { Schwartz, } 2009 \\
\text { Randomized Controlled Trial; Germany } \\
\text { Sample Size: } \\
\text { Intervention Group Baseline N: } 66 \\
\text { Control Group Baseline N: } 66 \\
\text { Intervention Group Analytic N: } 53 \\
\text { Control Group Analytic N: } 49 \\
\text { Attrition: } 23 \% \\
\text { Power Analysis/Sufficient Sample Size: } \\
\text { N=60/group to detect a } 10 \% \text { higher blood n-3 } \\
\text { fatty acid levels with alpha of } 0.05 \text { and } 95 \% \\
\text { power (SD of } 12 \%) \text {. } \\
\text { Sex: } \\
\text { 50\% Female } \\
\text { Race/Ethnicity: } \\
\text { NR } \\
\text { Background Diet: } \\
\text { EBF duration: } 19 w k \\
\text { Age of CFB introduction: } 21 w k\end{array}$ & $\begin{array}{l}\text { Intervention Group: Received one } \\
\text { jar/d (190g for 4-7mo, } 220 \mathrm{~g} \text { for } 7- \\
\text { 10mo) for } 4 \mathrm{mo} \text { of a meat meal } \\
\text { with rapeseed (canola) oil (LA } \\
\text { 20\%; ALA 9\%; LA/ALA 2.2); } \\
\text { LA/ALA ratio of } 3.9 \\
\text { Control Group: Received one } \\
\text { jar/d (190g for 4-7mo, } 220 \mathrm{~g} \text { for } 7- \\
\text { 10mo) for } 4 \text { mo of a meat meal } \\
\text { with corn oil (LA 55\% of total fatty } \\
\text { acid; ALA 1\%; LA/ALA 55); } \\
\text { LA/ALA ratio of 35.7 } \\
\text { Age: } 6-10 \text { mo } \\
\text { Assessment Methods } \\
\text { Food record, daily }\end{array}$ & $\begin{array}{l}\text { Weight } \\
\text { Age: } 4-10 \mathrm{mo} \text {; } 10 \mathrm{mo} \\
\text { Assessment Methods NR }\end{array}$ & $\begin{array}{l}\text { Confounders accounted for: } \\
\text { Birth size: } X(\text { All }>2.5 \mathrm{~kg}) \\
\text { Limitations: } \\
\text { Cannot determine validity/reliability } \\
\text { of outcome measures (methods not } \\
\text { described); Did not account for high } \\
\text { loss to follow-up (23\%) } \\
\\
\text { Study was powered to detect } \\
\text { differences in plasma fatty acids } \\
\text { levels, so may not have been } \\
\text { adequately powered to detect } \\
\text { differences in growth }\end{array}$ \\
\hline $\begin{array}{l}\text { Sonneville, } 2015 \\
\text { Prospective Cohort Study; United States } \\
\text { Sample Size: } \\
\text { Baseline N: } 2128 \\
\text { Analytic N: } 1163 \\
\text { Attrition: } 45 \% \\
\text { Power Analysis: NR } \\
\text { Sex: } \\
50 \% \text { Female } \\
\text { Race/Ethnicity: } \\
70 \% \text { White, } 12 \% \text { Black, } 4 \% \text { Hispanic, } 3 \% \\
\text { Asian } \\
\text { Background Diet: } \\
\text { BF duration: } 6.4 \mathrm{~m} 0\end{array}$ & $\begin{array}{l}\text { Juice intake (OJ, 100\% fruit) } \\
\text { servings/d: } 0,1-7,8-15,16-31 \text {, or } \\
>32 \text { ounces } \\
\text { Age:1y } \\
\text { Assessment Methods } \\
\text { Maternal questionnaire }\end{array}$ & $\begin{array}{l}\text { Body composition } \\
\text { Age: } 3.1 y, 7.7 y \\
\text { Assessment Methods } \\
\text { Body composition: BMIZ, } \\
\text { calculated using measured } \\
\text { height, weight, and converted to } \\
\text { age- and sex-specific z-scores } \\
\text { based on US reference growth } \\
\text { data_ }\end{array}$ & $\begin{array}{l}\text { Confounders accounted for: } \\
\text { Education: X } \\
\text { SES: X } \\
\text { Sex: X } \\
\text { Maternal age: X } \\
\text { Race/ethnicity: X } \\
\text { Other: Maternal age, prepregnancy } \\
\text { BMI, child age, WLZ at 1y, caloric } \\
\text { intake } \\
\text { Limitations: } \\
\text { Groups differed at baseline on BF } \\
\text { duration, which was not adjusted for } \\
\text { in analyses; Cannot determine } \\
\text { whether outcome assessors were } \\
\text { blinded; Cannot determine the } \\
\text { validity/reliability of outcome } \\
\text { assessment (i.e., single vs multiple } \\
\text { growth measures); Did not account }\end{array}$ \\
\hline
\end{tabular}




\begin{tabular}{|c|c|c|c|}
\hline & & & $\begin{array}{l}\text { for high loss to follow-up (45\%); Did } \\
\text { not adjust for potential key } \\
\text { confounders (feeding practices, birth } \\
\text { size, gestational age) } \\
\text { Did not distinguish between } 100 \% \\
\text { fruit juice and non-100\% fruit juice }\end{array}$ \\
\hline $\begin{array}{l}\text { Tang, } 2014 \\
\text { Randomized Controlled Trial; China } \\
\text { Sample Size: } \\
\text { Baseline N: } 1471 \\
\text { Analytic N: } 1318 \\
\text { Attrition: } 10 \% \\
\text { Power Analysis and Sufficient Sample Size: } \\
\text { NR } \\
\text { Sex: } \\
\text { NR } \\
\text { Race/Ethnicity: } \\
\text { NR } \\
\text { Background Diet: } \\
\text { EBF: } 100 \% \text { at enrollment }\end{array}$ & $\begin{array}{l}\text { Pork group: Received } 60 \mathrm{~g} / \mathrm{d} \text { of } \\
\text { fresh, certified safe pork, to be } \\
\text { boiled by the parents from } 6- \\
18 m o \\
\text { Cereal group: Received daily } \\
\text { supplements of a commercially } \\
\text { available or isocaloric packaged } \\
\text { pressed rice cereal product from } \\
6-18 m 0 \\
\text { Age: } 6-18 m o \\
\text { Assessment Methods } \\
\text { Food diaries }\end{array}$ & $\begin{array}{l}\text { Body composition; Weight; } \\
\text { Length; HC } \\
\text { Age: } 6 \mathrm{mo}, 7 \mathrm{mo}, 9 \mathrm{mo}, 12 \mathrm{mo} \text {, } \\
15 \mathrm{mo}, 18 \mathrm{mo} \\
\text { Assessment Methods } \\
\text { Body composition: WLZ from } \\
\text { measured weight/length } \\
\text { Weight: weight and WAZ, } \\
\text { measured by study personnel, to } \\
\text { nearest } 5 \mathrm{~g} \\
\text { Length: Measured by study } \\
\text { personnel, to nearest } 0.1 \mathrm{~cm} \\
\text { HC: NR. }\end{array}$ & $\begin{array}{l}\text { Confounders accounted for: } \\
\text { Education: } X \\
\text { SES: } X \\
\text { Feeding practices: } X \text { (all EBF) } \\
\text { Gestational age: } X \text { (all full term) } \\
\text { Other: Maternal height and weight, } \\
\text { baseline length } \\
\text { Limitations: } \\
\text { Cannot determine whether group } \\
\text { allocation was concealed; Cannot } \\
\text { determine whether adherence was } \\
\text { similar between groups; Participants } \\
\text { were not blinded; cannot determine } \\
\text { whether investigators or outcome } \\
\text { assessors were blinded; Cannot } \\
\text { determine the validity/reliability of } \\
\text { outcome assessment (i.e., single vs } \\
\text { multiple growth measures) }\end{array}$ \\
\hline
\end{tabular}




\begin{tabular}{|c|c|c|c|}
\hline $\begin{array}{l}\text { Tang, 2014b } \\
\text { Randomized Controlled Trial; United States } \\
\text { Sample Size: } \\
\text { Baseline N: } 45 \\
\text { Analytic N: } 42 \\
\text { Attrition: } 7 \% \\
\text { Power Analysis and Sufficient Sample Size: } \\
\text { NR for this secondary analysis. Authors do } \\
\text { state that they had } 50 \% \text { and } 60 \% \text { power to } \\
\text { test changes in LAZ and WAZ respectively. } \\
\text { Sex: } \\
60 \% \text { Female } \\
\text { Race/Ethnicity: } \\
\text { NR } \\
\text { Background Diet: } \\
\text { EBF: } 100 \% \text { at enrollment }\end{array}$ & $\begin{array}{l}\text { Meat group: Received one jar/d of } \\
\text { pureed meat and gravy ( } 71 \mathrm{~g} \\
\text { total, equivalent to } 8 \mathrm{~g} \text { protein) by } \\
7 \mathrm{mo} \text { of age and } 1-2 \text { jars } / \mathrm{d} \text { by } 9 \mathrm{mo} \\
\text { of age } \\
\text { Cereal group: Received } 1 \\
\text { serving/d of cereal }(15 \mathrm{~g} \text { dry } \\
\text { weight by manufacturer's label, } \\
\text { iron or iron-zinc fortified) by } 7 \mathrm{mo} \\
\text { of age and } 2 \text { servings } / \mathrm{d} \text { by } 9 \text { mo } \\
\text { of age; asked to avoid meats } \\
\text { Age: } 5-9 \text { mo } \\
\text { Assessment Methods } \\
\text { Food records, } 3 \mathrm{~d}\end{array}$ & $\begin{array}{l}\text { Body composition; Weight; } \\
\text { Length; WC } \\
\text { Age: } 5,6,7,8,9 \text { mo Assessment } \\
\text { Methods } \\
\text { Body composition: BMI and WLZ } \\
\text { calculated via measured height, } \\
\text { weight- } \\
\text { Weight:WAZ, measured by study } \\
\text { personnel, duplicate } \\
\text { Length: LAZ, ,easured by study } \\
\text { personnel, to nearest } 0.1 \mathrm{~cm}, \\
\text { duplicate } \\
\text { WC: NR }\end{array}$ & $\begin{array}{l}\text { Confounders accounted for: } \\
\text { Birth size: X (All appropriate for } \\
\text { gestational age) } \\
\text { Gestational age: X (All full term) } \\
\text { Limitations: } \\
\text { Cannot determine whether group } \\
\text { allocation was concealed; } \\
\text { Participants and investigators were } \\
\text { not blinded; cannot determine } \\
\text { whether outcome assessors were } \\
\text { blinded; Cannot determine the } \\
\text { validity/reliability of outcome } \\
\text { assessment (i.e., head, waist } \\
\text { circumference) }\end{array}$ \\
\hline $\begin{array}{l}\text { Tantracheewathorn, } 2005 \\
\text { Prospective Cohort Study; Thailand } \\
\text { Sample Size: } \\
\text { Baseline N: } 156 \\
\text { Analytic N: } 140 \\
\text { Attrition: } 10 \% \\
\text { Power Analysis and Sufficient Sample Size: } \\
\mathrm{N}=156 \text { to detect a } 0.57 \mathrm{~kg}(\mathrm{SD}=1.16) \\
\text { difference in weight at } 12 \mathrm{mo} \text { with a power of } \\
80 \% \text {, pvalue of } 0.05 \text {, and } 20 \% \text { loss to follow- } \\
\text { up } \\
\text { Sex: } \\
50 \% \text { Female } \\
\text { Race/Ethnicity: } \\
\text { NR } \\
\text { Background Diet: } \\
\text { BF: } 50 \%, \text { FF: } 50 \%\end{array}$ & $\begin{array}{l}\text { Adequate complementary food: } \\
\text { consumed a variety of food from } \\
\text { various food groups (rice and } \\
\text { grains, fruits, vegetables, milk, } \\
\text { meat, eggs, fat), and adequate } \\
\text { amounts of nutrient and energy } \\
\text { compared with Thai } \\
\text { Recommended Dietary } \\
\text { Allowances } \\
\text { Age: Data collected at } 1,2,4,6 \text {, } \\
9,12 \text { mo, but cannot determine } \\
\text { when CFB adequacy was } \\
\text { assessed Assessment Methods } \\
\text { Parental interview, } 24 \mathrm{hr} \text { recall }\end{array}$ & $\begin{array}{l}\text { Weight status } \\
\text { Age: Cannot determine } \\
\text { Assessment Methods } \\
\text { Weight status: malnutrition } \\
\text { (Wasting, Stunting, Underweight) } \\
\text { calculated using measured } \\
\text { height, weight, defined by WAZ, } \\
\text { LAZ, or weight-for-height Z-score } \\
\text { (WHZ) <2SD of the Thai } \\
\text { references. }\end{array}$ & $\begin{array}{l}\text { Confounders accounted for: } \\
\text { Feeding practices: } X \\
\text { Birth size: X (All>2500g) } \\
\text { Gestational age: X (All 37-42wk) } \\
\text { Limitations: } \\
\text { Cannot determine whether groups } \\
\text { were similar at baseline on key } \\
\text { characteristics; Cannot determine } \\
\text { whether outcome assessors were } \\
\text { blinded; Cannot determine the } \\
\text { validity/reliability of outcome } \\
\text { measures (i.e., single vs multiple } \\
\text { measures); Did not adjust for key } \\
\text { confounders (education, SES, sex, } \\
\text { maternal age, race/ethnicity); } \\
\text { Adequacy of statistical methods } \\
\text { insufficient (unclear what time points } \\
\text { were used to calculate the exposure } \\
\text { and outcome variables) }\end{array}$ \\
\hline
\end{tabular}




\begin{tabular}{|c|c|c|c|}
\hline $\begin{array}{l}\text { Virtanen, } 2001 \\
\text { Randomized Controlled Trial; Sweden } \\
\text { Sample Size: } \\
\text { Baseline N: } 54 \\
\text { Analytic N: } 36 \\
\text { Attrition: } 33 \% \\
\text { Sample Size Calculation: } \mathrm{N}=50 \text { ( } 25 \text { in each } \\
\text { group) to detect differences in Hb (4.0g/L) } \\
\text { and TfR ( } 0.8 \mathrm{mg} / \mathrm{L}) \text { concentration } \\
\text { Sex: } \\
67 \% \text { Female } \\
\text { Race/Ethnicity: } \\
\text { 100\% White } \\
\text { Background Diet: } \\
\text { All feeding according to current Swedish } \\
\text { guidelines (BF at birth, and if not, fed Fe- } \\
\text { fortified infant formula until } 6 \text { mo; After } 6 \mathrm{mo} \text { of } \\
\text { age all (except 3) fed Fe-forti } \square \text { fied follow-on } \\
\text { formula with meal) }\end{array}$ & $\begin{array}{l}\text { Cow's milk group: Received either } \\
\text { low-fat or standard-fat cow's milk, } \\
\text { ad libitum } \\
\text { Iron-fortified cow's milk groups: } \\
\text { Received either Fe-fortified cow's } \\
\text { milk, fortified with ferrous } \\
\text { gluconate-fortified cows milk with } \\
50 \% \text { of the fat being vegetable } \\
\text { fat, or Fe-fortified cow's milk, } \\
\text { fortified with ferrous lactate-- } \\
\text { fortified cows milk with } 100 \% \text { of } \\
\text { the fat being vegetable fat, ad } \\
\text { libitum } \\
\text { Age:12-18mo } \\
\text { Assessment Methods } \\
\text { Food record, } 7 \mathrm{~d}\end{array}$ & $\begin{array}{l}\text { Weight } \\
\text { Age: } 12-18 \mathrm{mo} ; 18 \mathrm{mo} \\
\text { Assessment Methods } \\
\text { Weight: absolute and change in } \\
\text { weight; measured by study } \\
\text { personnel, to nearest } 5 \mathrm{~g} .\end{array}$ & $\begin{array}{l}\text { Confounders accounted for: } \\
\text { Race/ethnicity: X (100\% white) } \\
\text { Limitations: } \\
\text { Cannot determine the } \\
\text { validity/reliability of outcome } \\
\text { assessment (i.e., single vs multiple } \\
\text { measures); Did not account for high } \\
\text { loss to follow-up (33\%) } \\
\text { Author noted study may not have } \\
\text { been adequately powered_ }\end{array}$ \\
\hline $\begin{array}{l}\text { Walter, } 1993 \\
\text { Randomized Controlled Trial; Chile } \\
\text { Sample Size: } \\
\text { Baseline N: } 515 \\
\text { Analytic N: } 444 \text { at } 8 \mathrm{mo}, 370 \text { at } 12 \mathrm{mo}, 340 \text { at } \\
15 \mathrm{mo} \\
\text { Attrition: } 14 \% \text { at } 8 \mathrm{mo}, 28 \% \text { at } 12 \mathrm{mo}, 34 \% \text { at } \\
15 \mathrm{mo} \\
\text { Power Analysis/Sample Size Calculation: NR } \\
\text { Sex: } \\
\text { NR } \\
\text { Race/Ethnicity: } \\
\text { NR } \\
\text { Background Diet: } \\
\text { EBF: } 100 \% \text { at enrollment }\end{array}$ & $\begin{array}{l}\text { FF infants were randomized to } \\
\text { one of the following three groups: } \\
\text { Group 1: Received Fe-fortified } \\
\text { cereal (30g/d) + unfortified } \\
\text { formula } \\
\text { Group 2: Received unfortified } \\
\text { cereal + unfortified formula } \\
\text { Group 3: Received unfortified } \\
\text { cereal + fortified formula } \\
\text { BF infants were randomized to } \\
\text { one of the following two groups: } \\
\text { Group 4: Fe-fortified cereal + } \\
\text { breastmilk } \\
\text { Group 5: Unfortified cereal + } \\
\text { breastmilk } \\
\text { Age: 4-15mo } \\
\text { Assessment Methods } \\
\text { Food record, daily, measured }\end{array}$ & $\begin{array}{l}\text { Weight; Length } \\
\text { Age: } 8,12,15 \mathrm{mo} \\
\text { Assessment Methods } \\
\text { Weight: NR } \\
\text { Length: NR. }\end{array}$ & $\begin{array}{l}\text { Confounders accounted for: } \\
\text { Other: } \\
\text { Limitations: } \\
\text { Cannot determine whether group } \\
\text { allocation was concealed; Cannot } \\
\text { determine whether the groups } \\
\text { differed at baseline on key } \\
\text { characteristics; Cannot determine } \\
\text { whether investigators or outcome } \\
\text { assessors were blinded; Cannot } \\
\text { determine the validity/reliability of } \\
\text { outcome assessment (methods not } \\
\text { described); Did not account for high } \\
\text { loss to follow-up (60\%); Adequacy of } \\
\text { statistical methods insufficient } \\
\text { (statistical tests and p-values are not } \\
\text { consistently provided) }\end{array}$ \\
\hline
\end{tabular}




\begin{tabular}{|c|c|c|c|}
\hline $\begin{array}{l}\text { Wen, 2014a } \\
\text { Prospective Cohort Study; United States } \\
\text { Sample Size: } \\
\text { Baseline N: } 3033 \\
\text { Analytic N: } 530 \\
\text { Attrition: } 83 \% \\
\text { Power Analysis and Sufficient Sample Size: } \\
\text { NR } \\
\text { Sex: } \\
50 \% \text { female } \\
\text { Race/Ethnicity: } \\
91 \% \text { White, } 1 \% \text { African American, } 3 \% \\
\text { Hispanic, 3\% Asian/Pacific Islander } \\
\text { Background Diet: } \\
\text { NR }\end{array}$ & $\begin{array}{l}\text { Four dietary patterns were } \\
\text { identified using principal } \\
\text { component analysis, and infants } \\
\text { were assigned an adherence } \\
\text { score to each pattern at 6mo: } \\
\text { Infant guideline solids: Baby } \\
\text { cereal, fruit, vegetables, } \\
\text { meat/chicken } \\
\text { High sugar/fat/protein: Sweet } \\
\text { drinks, French fries, fish/shellfish, } \\
\text { nut foods, eggs, sweet foods } \\
\text { High dairy/regular cereal: Cow's } \\
\text { milk, other dairy, 100\% juice, non- } \\
\text { baby cereals/starches } \\
\text { Formula: Formula, low intakes of } \\
\text { breast milk } \\
\text { Age: } 6 \text { mo } \\
\text { Assessment Methods } \\
\text { FFQ }\end{array}$ & $\begin{array}{l}\text { Body composition; Length } \\
\text { Age: } 6-12 \text { mo } \\
\text { Assessment Methods } \\
\text { Body composition: change in BMI, } \\
\text { calculated using maternal report } \\
\text { of weight/length. } \\
\text { Length: Maternal report }\end{array}$ & $\begin{array}{l}\text { Confounders accounted for: } \\
\text { Education: X } \\
\text { SES: X } \\
\text { Sex: X } \\
\text { Maternal age: X } \\
\text { Race/ethnicity: X } \\
\text { Feeding practices: X (other dietary } \\
\text { pattern scores) } \\
\text { Gestational age: X } \\
\text { Other: Growth at 6mo, pre- } \\
\text { pregnancy BMI, gestational diabetes, } \\
\text { gestational weigh gain } \\
\text { Limitations: } \\
\text { Dietary pattern adherence was } \\
\text { associated with birth weight, which } \\
\text { was not adjusted for in analyses; } \\
\text { Outcome assessors were not blinded } \\
\text { (maternal report); Did not use } \\
\text { valid/reliable measures to assess } \\
\text { outcomes (maternal report of infant } \\
\text { weight, length); Did not account for } \\
\text { high loss to follow-up (85\%); Did not } \\
\text { adjust for potential key confounders } \\
\text { (birth size) }\end{array}$ \\
\hline $\begin{array}{l}\text { Wosje, } 2001 \\
\text { Prospective Cohort Study; United States } \\
\text { Sample Size: } \\
\text { Baseline N: } 121 \\
\text { Analytic N: } 51 \\
\text { Attrition: } 58 \% \\
\text { Power Analysis and Sufficient Sample Size: } \\
\text { NR } \\
\text { Sex: } \\
45 \% \text { Female } \\
\text { Race/Ethnicity: } \\
94 \% \text { White }\end{array}$ & $\begin{array}{l}\text { Type of milk consumed: } 2 \% \text { vs. } \\
\text { whole milk } \\
\text { Age: } 12 \text { mo } \\
\text { Assessment Methods } \\
\text { Food record, } 3 d\end{array}$ & $\begin{array}{l}\text { Body composition; Weight; } \\
\text { Length } \\
\text { Age: } 24 \mathrm{mo} \\
\text { Assessment Methods } \\
\text { Body composition: \% body fat via } \\
\text { DXA } \\
\text { Weight: Measured by study } \\
\text { personnel to } 0.001 \mathrm{~kg} \\
\text { Length: Measured by study } \\
\text { personnel, to } 0.5 \mathrm{~cm} \text {, recumbent }\end{array}$ & $\begin{array}{l}\text { Confounders accounted for: } \\
\text { Limitations: } \\
\text { Did not account for dietary intake } \\
\text { aside from type of milk consumed; } \\
\text { Cannot determine whether outcome } \\
\text { assessors were blinded; Cannot } \\
\text { determine the validity/reliability of } \\
\text { outcome assessment (i.e., single vs } \\
\text { multiple measures) ; Did not account } \\
\text { for high loss to follow-up (58\%); Did } \\
\text { not adjust for key confounders } \\
\text { (education, SES, sex, maternal age, }\end{array}$ \\
\hline
\end{tabular}




\begin{tabular}{|c|c|c|c|}
\hline$\frac{\text { Background Diet: }}{\text { NR }}$ & & & $\begin{array}{l}\text { race/ethnicity, feeding practices, } \\
\text { birth size, gestational age) }\end{array}$ \\
\hline $\begin{array}{l}\text { Yeung, } 2000 \\
\text { Randomized Controlled Trial; Canada } \\
\text { Sample Size: } \\
\text { Intervention Baseline N: } 79 \\
\text { Control Baseline N: } 77 \\
\text { Intervention Analytic N: } 49 \\
\text { Control Analytic N: } 54 \\
\text { Attrition: } 34 \% \\
\text { Sample Size Calculation: N=55 per group to } \\
\text { detect differences in Fe depletion } \\
\text { Sex: } \\
48 \% \text { Female } \\
\text { Race/Ethnicity: } \\
\text { NR } \\
\text { Background Diet: } \\
\text { All subjects in the intervention group were } \\
\text { fed cow's milk; in the control group, cow milk } \\
\text { was delayed until } 10 \text { mo }\end{array}$ & $\begin{array}{l}\text { Intervention group: Received } \\
\text { pureed meat (1-2 jars/d) and Fe- } \\
\text { fortified infant cereals }(2 / 3 \mathrm{c} / \mathrm{d}) \\
\text { from } 6 \text { to } 12 \mathrm{mo} \text {; all other foods } \\
\text { allowed at parents' discretion } \\
\text { (except vitamin/mineral } \\
\text { supplements containing Fe and } \\
\text { Fe-fortified formulas) } \\
\text { Control group: No dietary } \\
\text { intervention } \\
\text { Age: } 6-12 \text { mo } \\
\text { Assessment Methods } \\
\text { Parent questionnaire }\end{array}$ & $\begin{array}{l}\text { Weight; Length; HC } \\
\text { Age: } 8,10,12 \mathrm{mo} \\
\text { Assessment Methods } \\
\text { Weight: Measured by study } \\
\text { personnel, in triplicate } \\
\text { Length: Measured by study } \\
\text { personnel, recumbent, in triplicate } \\
\text { HC: Measured by study personnel } \\
\text { in triplicate. }\end{array}$ & $\begin{array}{l}\text { Confounders accounted for: } \\
\text { Gestational age: X (All full term) } \\
\text { Limitations: } \\
\text { Participants and outcome assessors } \\
\text { were not blinded; Did not account for } \\
\text { high loss to follow-up }(\sim 34 \%)\end{array}$ \\
\hline $\begin{array}{l}\text { Zheng, } 2015 \\
\text { Prospective Cohort Study; China } \\
\text { Sample Size: } \\
\text { Baseline N: } 90066 \\
\text { Analytic N: } 40510 \\
\text { Attrition: } 55 \% \\
\text { Power Analysis and Sufficient Sample Size: } \\
\text { NR } \\
\text { Sex: } \\
48 \% \text { Female } \\
\text { Race/Ethnicity: } \\
\text { NR } \\
\text { Background Diet: } \\
\text { Ever BF: 93\% }\end{array}$ & $\begin{array}{l}\text { Age of CFB introduction: }<3,4-6 \text {, } \\
>6 \text { mo } \\
\text { CFB: fish liver oil, rice } \\
\text { cereal/porridge, egg yolk, fish } \\
\text { paste, liver paste, tofu, animal } \\
\text { blood, bread/steamed bun/fine } \\
\text { dried noodle, ground meat/soy } \\
\text { product, and pureed } \\
\text { noodle/cookies } \\
\text { Age: } 1,3,6 \text { mo } \\
\text { Assessment Methods: } \\
\text { Maternal interview }\end{array}$ & $\begin{array}{l}\text { Weight status; Body composition } \\
\text { Age: 4-5y } \\
\text { Assessment Methods: } \\
\text { Weight status: Obesity defined as } \\
\text { BMl z-score>2SD, overweight } \\
\text { defined as between 1-2SD } \\
\text { Body composition: BMI calculated } \\
\text { using self-reported weight, height }\end{array}$ & $\begin{array}{l}\text { Confounders accounted for: } \\
\text { Education: } X \\
\text { SES: } X \\
\text { Sex: } X \\
\text { Feeding practices: X (BF, timing of } \\
\text { other CFB) } \\
\text { Birth size: } X \text { (Birth weight) } \\
\text { Gestational age: } X \\
\text { Other: Maternal menarcheal age, } \\
\text { type of delivery, maternal BMI, } \\
\text { maternal occupation, weight gain by } \\
\text { 3mo, age of other children } \\
\\
\text { Limitations: } \\
\text { Outcome assessors were not } \\
\text { blinded; Did not use valid/reliable }\end{array}$ \\
\hline
\end{tabular}




\begin{tabular}{|l|l|l|l|}
\hline & & $\begin{array}{l}\text { measures to assess outcomes } \\
\text { (weight was self-reported; lack of } \\
\text { detail provided); Did not account for } \\
\text { high loss to follow-up (55\%); Did not } \\
\text { adjust for potential key confounders } \\
\text { (sex, maternal age, race/ethnicity) } \\
\text { Concern for multiple testing } \\
\text { (analyzed two correlated outcomes } \\
\text { [BMl, weight status] across many } \\
\text { types of foods, increasing chance of } \\
\text { false-positives } \\
\text { Cohort data collected over a long } \\
\text { interval (1999-2009) } \\
\text { Limited generalizability due to } \\
\text { population having very low } \\
\text { prevalence of obesity (<2\%) }\end{array}$ \\
& & & \\
\hline
\end{tabular}


